\author{
UNIVERSIDADE DE SÃO PAULO \\ ESCOLA DE ENGENHARIA DE SÃO CARLOS \\ DEPARTAMENTO DE ENGENHARIA DE PRODUÇÃO
}

\title{
Análise de Eficiência em Rotas de Transporte de Soja nos Principais Corredores Brasileiros e Norte-Americanos utilizando Análise Envoltória de Dados (DEA)
}

Dissertação apresentada à Escola de Engenharia de São Carlos, da Universidade de São Paulo, como parte dos requisitos para obtenção do título de Mestre em Engenharia de Produção.

ISOTILIA COSTA MELO

Orientadora: Prof ${ }^{a}$. Dr. ${ }^{a}$ Daisy A. do N. Rebelatto

SÃO CARLOS

2017 


\section{ISOTILIA COSTA MELO}

\section{Análise de Eficiência em Rotas de Transporte de Soja nos Principais Corredores Brasileiros e Norte-Americanos utilizando Análise Envoltória de Dados (DEA)}


AUTORIZO A REPRODUÇÃO TOTAL OU PARCIAL DESTE TRABALHO, POR QUALQUER MEIO CONVENCIONAL OU ELETRÔNICO, PARA FINS DE ESTUDO E PESQUISA, DESDE QUE CITADA A FONTE.

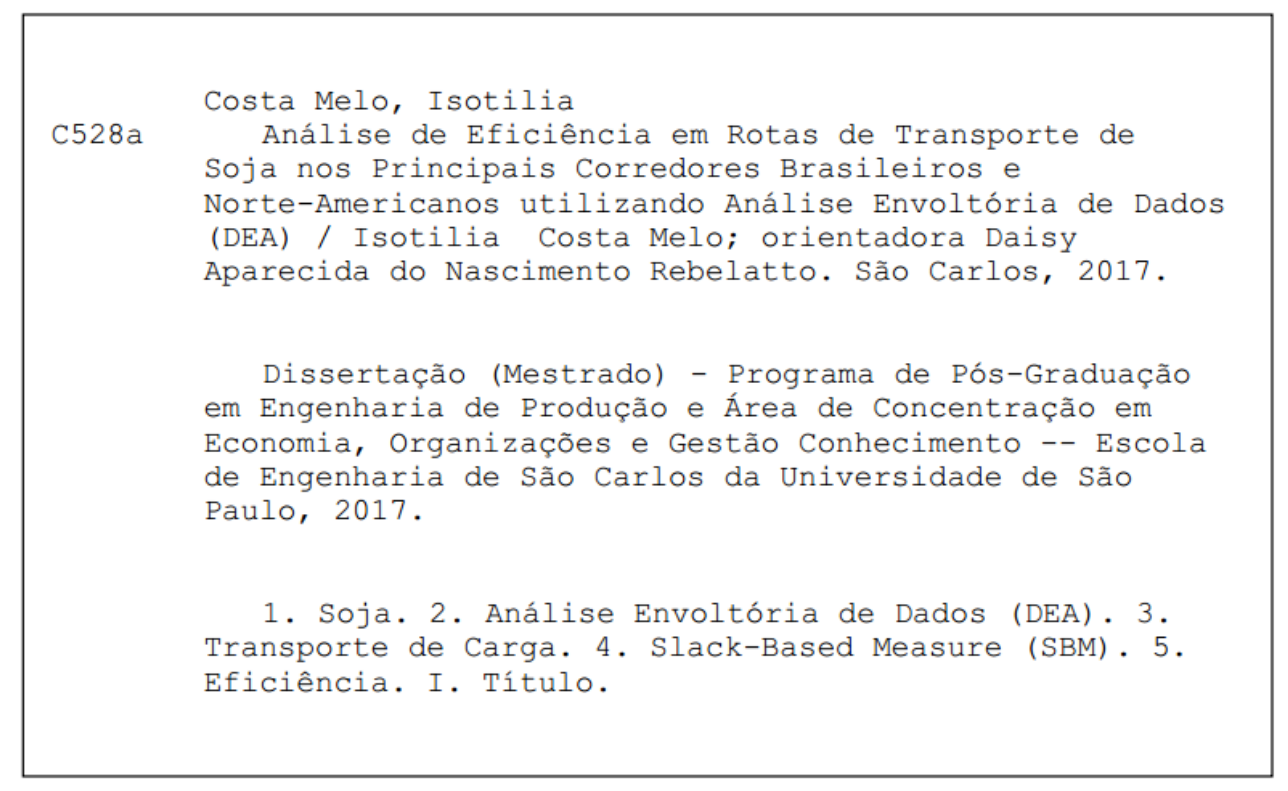




\section{FOLHA DE JULGAMENTO}

Candidata: Engenharia ISOTILA COSTA MELO.

Titulo da dissertaçāo: "Análise de eficiência em rotas de transporte de soja nos principais corredores brasileiros e norte-americanos ufilizando análise envoltória de dados (DEA)".

Data da defesa: 02/08/2017.

\section{Comissâo Julgadora:}

\section{Resultado:}

Profa. Associada Daisy Aparecida do Nascimento Rebelalto (Orientadora)

(Escola de Engenharia de São Carlos/EESC)

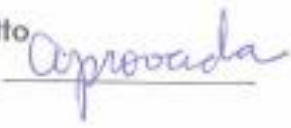

Profa. Dra, Ana Elisa Périco Aprownan

(Universidade Estadual Paulista "Júlio de Mesquita Filho"/UNESP . Araraquara)

Prof. Titular José Vicente Caixeta Fliho APRO UADO

(Escola Superior de Agricultura Luiz de Queiroz/ESALQ-USP)

Coordenador do Programa de Pós-Graduação em Engenharia de Produçâo:

Prof, Associado Aldo Roberto Ometto

Presidente da Comissāo de Pós-Graduaçāo: Prof. Associado Luis Fernando Costa Alberto 
Dedico este trabalho aos meus pais e à cientista Johanna Liesbeth Kubelka Döbereiner (in memorian), que dedicou sua vida a melhorar a produtividade da soja brasileira. 


\section{AGRADECIMENTOS}

Agradeço ao Eterno, bendito seja, por todas as bênçãos. Eu não mereci nenhuma delas.

Agradeço aos meus pais, Demerval e Auzenda, assim como a todos os meus antepassados.

Imensa gratidão a minha orientadora Prof. ${ }^{a}$ Dr. ${ }^{a}$ Daisy Aparecida do Nascimento Rebelatto.

Agradeço a todos os mestres espirituais que sempre me inspiraram com suas obras, me protegeram e guiaram. Num ecumenismo bem brasileiro, em especial, a Masaharu Taniguchi e a Moshe Chaim Luzzatto.

É impossível citar todas as pessoas amigas que contribuíram diretamente para realização deste trabalho. Agradeço especialmente ao Paulo por me ajudar com a programação, por trocar ideias e pela companhia e lealdade em todas viagens acadêmicas e pessoais (No rastro da lua cheia, se chega a qualquer lugar!). Agradeço ao colega Diogo Ferraz, que teve a boa vontade de ler e sugerir melhorias em todo projeto. Agradeço ao meu colega Caio Falconi (da Mirian) pelas infinitas conversas sobre literatura e economia e por me explicar a relação intrínseca entre astrologia e previsões econômicas (Volta logo, Caio. Você faz falta aqui!).

Para citar apenas algumas pessoas das várias pessoas significativas, sou profundamente grata aos meus colegas de laboratório e departamento: Naja, Bruno, Jéssica, Wilson, Gabriela, Tatiana, Helena, Ennio, Fabiana, Luiz, Caio, Caio (da Fabi), Thales, Rodrigo, Daniela, Lie, Martin, Mirian, Daniel, Hugo, Camilla, Carol, Ana, Ana Laura, Juliana, Diego e Lucas. Em especial à Maria, por ter corrigido vários trabalhos nossos em inglês. Muito obrigada ao Felisberto (internacionalmente conhecido como Happybert), nosso coorientador peludo e fofo para as horas difíceis.

Muito obrigada a todos os colaboradores da USP que, com seu esforço diário, proporcionam um ambiente ideal ao trabalho acadêmico. Entre eles, as secretárias, 
Sueli, Jéssyca, Talita, Francis e Ana Paula, aos técnicos de informática, Ícaro e Luiz e a auxiliar de limpeza, Rebecca. .

Muito obrigada aos ex-colegas de engenharia mecânica que me ajudaram com essa pesquisa, em especial, ao Júlio, ao Cristiano, ao Valter, ao Thiago (do IW) e ao Vilarinho da Universidade Federal de Uberlândia (UFU). Muito obrigada ao Thiago da ESALQ-LOG, à Ana da UNESP (minha alma gêmea acadêmica) e ao Thanos da University of Strachclyde.

Muito obrigada aos inúmeros amigos, que me aguentaram nos momentos mais difíceis, sempre me apoiaram e me proporcionaram histórias incríveis. Entre eles, dos mais antigos para os mais novos, Juliana (se eu escrever há quantas décadas nós somos amigas, ela me processa!), Bruna, Ana Amélia, Wesley, Suellen, Thaís, Isabel, Paulo Agenor, Jaqueline, Gisele, Gabriel Urquiza, Carolina Nagai, Ralph, Salomão, Fernanda, Micail, Bruno Kim, Luzia, Padeiro, Coragem (pena que é um amigo imaginário!), Jaciara, Sarah, Marco Aurélio, Pazu, Klever, Marli, Paulo Cintra, Rafael Paranhos, Gabriel Oliveria, Giulia, Silvana, Camila Zanca e Marli.

Muito obrigada às meninas que moraram comigo, Ana Sofia, Regina, Beatriz e meu sobrinho Ricardo.

Muito obrigada a todos os meus primos, em especial, ao Lucas e a Lívia, que me ensinaram a ser mais tolerante e menos racista. A minha prima e madrinha, Cida. A minha prima Ana Paula, pela amizade. À Letícia, à Alcione, à Márcia, à Rocielle e à Dra. Maria Luiza, por serem mulheres empreendedoras, me mostrando, desde pequena, que tudo era possível.

Agradeço ao Karsten e a Jana, por nossas conversas intermináveis e risos até as lágrimas. Agradeço ao Charles que sempre corrigiu meu estilo para parecer mais American style e se recusa a falar comigo até eu terminar este texto e estar plenamente satisfeita com ele. Muito obrigada ao Sameer por revisar o inglês de alguns dos meus textos. Muito obrigada ao Jan.

Agradeço aos gringos de São Carlos pela companhia, amizade e histórias engraçadas: Sasha, Dalila, Nelson, Florent, Michal e Hans. 


\section{EPÍGRAFE}

No quintal lá de casa

Passava um pequeno rio

Que descia lá da serra

Ligeiro escorregadio

A água era cristalina

Que dava pra ver o chão

Ia cortando a floresta

$\mathrm{Na}$ direção do sertão

Lembrança ainda me resta

Guardada no coração...

E tudo era azul celeste

Brasileiro cor de anil

Nem bem começava o ano

Já era final de Abril

$O$ vento pastoreando

Aquelas nuvens no céu...

Fazia o mundo girar

Veloz como um carrossel

E levantava a poeira

E me arrancava o chapéu

Ah o tempo faz, tempo desfaz

E vai além sempre...

A vida vem lá de longe

É como se fosse um rio

Pra rio pequeno canoa

Pros grandes rios navios

E bem lá no fim de tudo

Começo de outro lugar

Será como Deus quiser

Como o destino mandar

No rastro da lua cheia

Se chega em qualquer lugar!

(No Rastro da Lua Cheia, letra de Almir Sater e Renato Teixeira) 


\section{RESUMO}

Melo, I. C. (2017). Análise de Eficiência em Rotas de Transporte de Soja nos Principais Corredores Brasileiros e Norte Americanos utilizando Análise Envoltória de Dados (DEA). Dissertação de Mestrado. Universidade de São Paulo. Escola de Engenharia de São Carlos. Programa de Pós-Graduação em Engenharia de Produção.

A presente pesquisa está inserida na questão da infraestrutura logística para o transporte de carga a granel, especificamente a soja, a partir das principais mesorregiões produtoras dos dois maiores produtores mundiais, Brasil e Estados Unidos, até os principais portos exportadores. Este trabalho tem por objetivo analisar a eficiência das rotas e corredores nacionais de transporte de soja, levando em consideração os três pilares da sustentabilidade (econômico, social e ambiental). O método parte de uma revisão de literatura sobre o tema, seguido de uma explanação sobre eficiência, por meio da Análise Envoltória de Dados (DEA), e uma contextualização do cenário de escoamento em ambos os países. Foram determinadas 72 rotas brasileiras e 30 norteamericanas com diversas composições de modais. Os dados foram analisados por correlação e análise de componentes principais (PCA) e teste de Wilcoxon. Em seguida, as variáveis foram inseridas num modelo DEA de Slack-Based Measure (SBM), que minimiza os inputs (variáveis de entrada) e maximiza outputs (variáveis de saída) simultaneamente. Foi aplicado, como técnica quantitativa de desempate, o índice composto. Os resultados mostraram que as rotas norte-americanas foram as mais eficientes. Além disso, combinações de curtos trajetos de caminhão e longas rotas de modais hidroviários ou ferroviários estavam entre as eficientes. Ou seja, os resultados se mostraram coerentes com a literatura e a expectativa de especialistas. Em resumo, o uso da DEA pode notadamente fortalecer a análise de rotas e corredores domésticos nacionais usados para o escoamento produtivo da soja a granel e pode direcionar políticas de investimento públicas e privadas.

Palavras-chave: Soja, Análise Envoltória de Dados (DEA), Transporte de Carga, Slack-Based Measure (SBM), Eficiência. 


\begin{abstract}
Melo, I. C. (2017). Analysis of the efficiency of soybean transportation routes in the main Brazilian and American corridors using Data Envelopment Analysis (DEA). Dissertation of Mastering. University of São Paulo. São Carlos Engineering School. Postgraduate Program of Production Engineering.

This research is focused on the logistics infrastructure issue used for bulk transportation, specifically soybeans, from the main producing municipalities of the world biggest producers, Brazil and USA, to the key exporting ports. This dissertation aims to analyze the efficiency of routes and corridors, taking into account the three pillars of sustainability (economic, social and environmental). The method starts with a literature review of corridor benchmarking, efficiency measurement through data envelopment analysis and contextualization of transportation scenarios in both countries. It was identified 72 routes in Brazil and 30 in the US, considering several combinations of transportation mode (road, inland waterway and rail). Data were analyzed through correlation, principal component analysis (PCA), and Wilcoxon Test. Subsequently, variables were inserted in Slack-Based Measure (SBM) DEA model. This model simultaneously minimizes inputs and maximizes outputs. It was applied the quantitative tiebreaking method of the compound index. The results showed that the American routes among the most efficient ones. In addition, the combinations of short trips of trucks and long trips of barges or trains were also among the most efficient. In other words, the results were coherent with literature and expectation of specialists. In summary, it is clear that the use of DEA can noticeably improve the strength of the analysis of national domestic routes and corridors used in the productive chain of bulk soybeans.
\end{abstract}

Keywords: Soybeans, Data Envelopment Analysis, Cargo Freight Transport, SlackBased Measure, Efficiency. 


\section{LISTA DE SIGLAS E ABREVIATURAS}

AM Amazonas

API Aggregated Performance Indicator

BA Bahia

DEA Data Envelopment Analysis

DMU Decision Making Units

EPA Environment Protection Agency

ES Espírito Santo

EUA Estados Unidos

EWTC East-West Transport Corridor

GEE Gases do Efeito Estufa

GHG Greenhouse Gases

GO Goiás

IA Iowa

ICT Information Communication Technology

IL Illinois

IN Indiana

IPCC Intergovernamental Panel on Climate Change

KPI Key Performance Indicator

L\&D Lock \& Dam

MA Maranhão

MN Minesota

MO Missouri

MS Mato Grosso do Sul

MT Mato Grosso

NTMG Net-Ton Miles per Gallons

PA Pará

PCA Principal Components Analysis 
PIL Programa de Investimento em Logística

PR Paraná

RS Rio Grande do Sul

SBM Slacks-Based Measure

SC Santa Catarina

SE $\quad$ Sergipe

SP São Paulo

SGCI Swedish Green Corridors Iniciative

TU Tonelada Útil Tracionada

UE União Europeia

US $\quad$ United States

WN Wisconsin 


\section{LISTA DE FIGURAS}

Figura 1 - Custos de um corredor com três ligações, segundo método do Banco Mundial........ 26

Figura 2 - Corredores de exportação representados como pares de custo e tempo por ligação. 27

Figura 3 - Mapa dos principais corredores da Europa, encorpados pelo projeto Super Verdes. 32

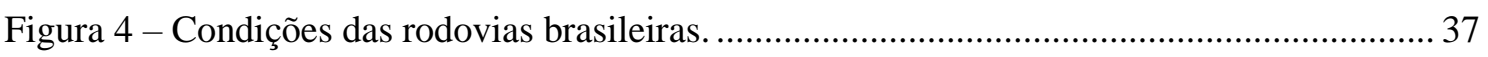

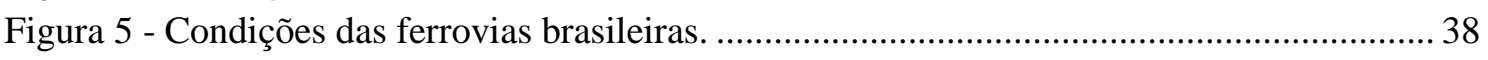

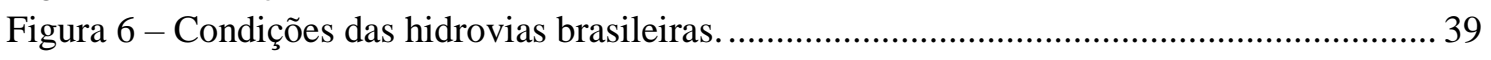

Figura 7 - Localização da Hidrovia Jacuí-Lagoa dos Patos. ......................................................... 40

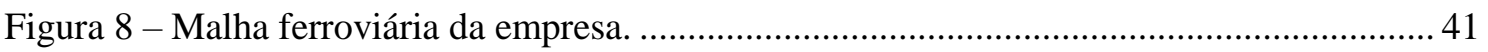

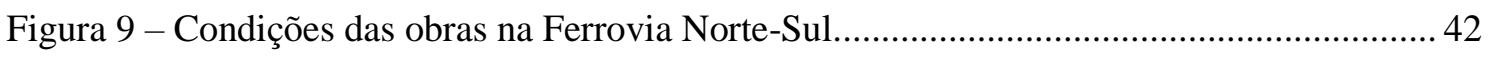

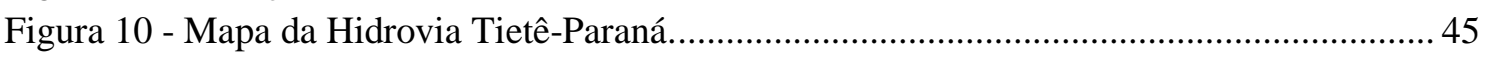

Figura 11 - Conexões ferroviárias para o PGH, porto especializado em exportação de grãos. .. 47

Figura 12 - Principais barragens e eclusas consideradas pelo presente estudo........................... 48

Figura 13 - Composição de barcaças no rio Mississipi. ................................................................. 49

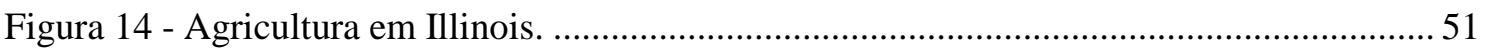

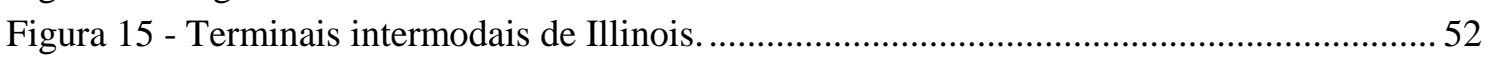

Figura 16 - Corredores de exportação que partem de Illinois.................................................... 53

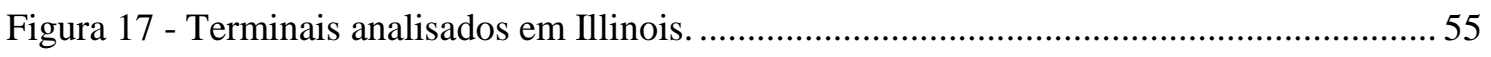

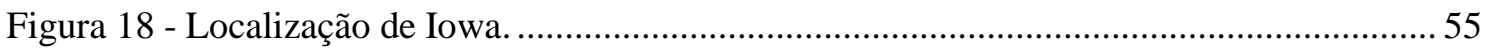

Figura 19 - Corredor de Iowa para o Golfo do Mississipi......................................................... 57

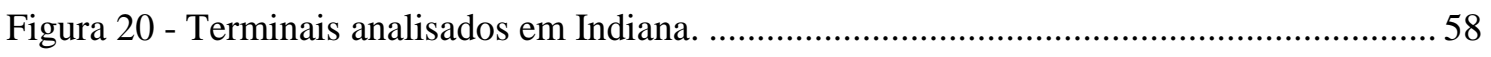

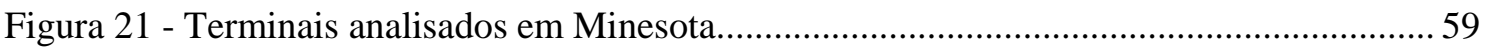

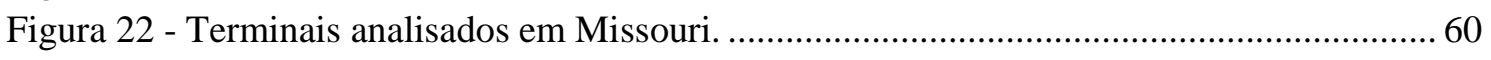

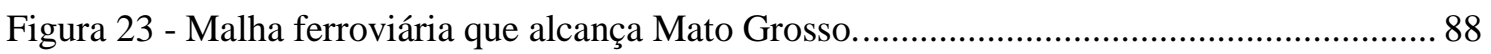

Figura 24 - Eclusas escolhidas para rotas de exportação estudadas........................................... 93

Figura 25 - Provável relação de dependência (causa e efeito) entre as variáveis........................ 98

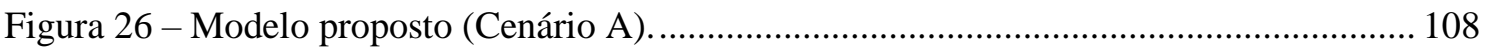




\section{LISTA DE QUADROS}

Quadro 1 - Definições do conceito de corredor verde................................................................ 22

Quadro 2 - Trabalhos conhecidos sobre comparação de rotas e corredores................................ 73

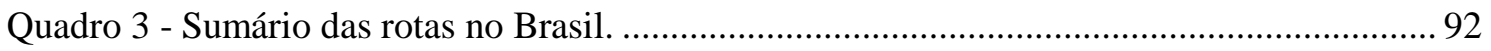

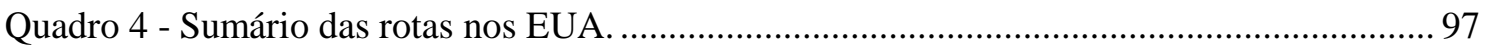




\section{LISTA DE TABELAS}

Tabela 1 Participação relativa dos portos brasileiros no escoamento para a safra 2014/2015 ... 35

Tabela 2 Valores compilados para eficiência energética de cada modal. .................................... 76

Tabela 3 Valores de eficiência energética adotados por modal para o modelo............................. 78

Tabela 4 Fator de conversão para cálculo das emissões de caminhões articulados. ...................... 80

Tabela 5 Fator de conversão para cálculo das emissões de locomotivas e barcas. ....................... 80

Tabela 6 Compilação dos valores considerados para o cálculo do fator de desgaste................... 84

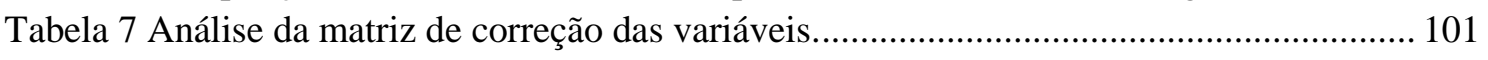

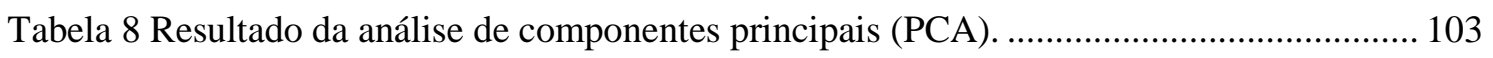

Tabela 9 Análise dos coeficientes que compõem as três primeiras componentes....................... 104

Tabela 10 Resultado do Teste de Wilcoxon entre Brasil e EUA. ............................................... 105

Tabela 11 Resultado de Wilcoxon entre rotas com um único modal e rotas com dois modais. 106

Tabela 12 Resultado de Wilcoxon entre rotas com um único modal e rotas com três modais. 106

Tabela 13 Resultado de Wilcoxon entre rotas com dois e três modais. ...................................... 106

Tabela 14 Compilação das características das dez rotas mais e menos eficientes. ..................... 109

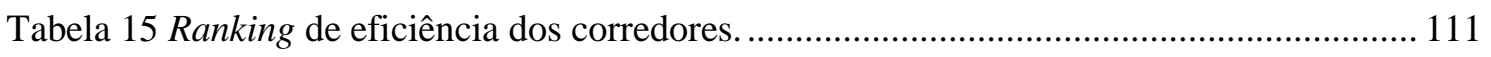

Tabela 16 Déficit de capacidade de armazenagem estática estadual. ........................................ 112

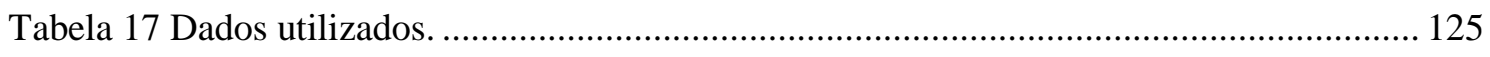

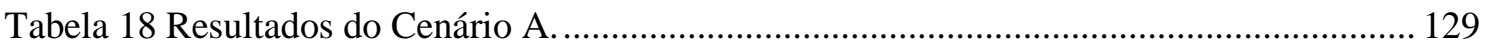

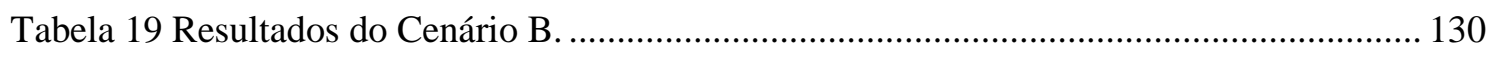

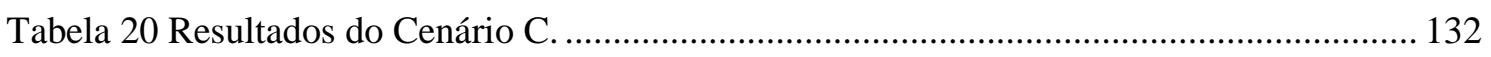




\section{SUMÁRIO}

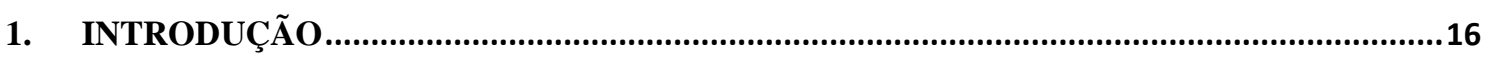

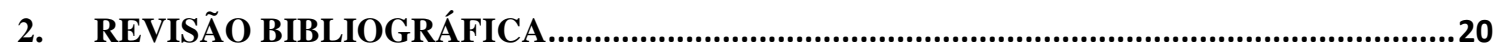

2.1. CoRREDORES DE TRANSPORTE DE CARGa: ESTAdo da ARTE PARA ANÁLISE DE DESEMPENHO ........20

2.1.1 Indicadores de Desempenho Chaves (KPIs) para Corredores ...............................................23

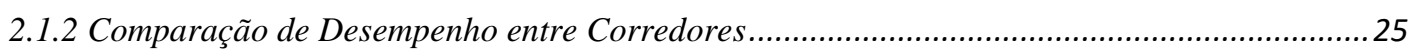

2.2. CARACTERIZAÇÃo dos CONTEXTOS BRASILEIROS E NORTE-AMERICANOS .....................................33

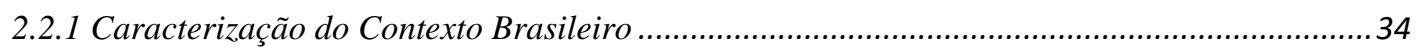

2.2.2 Caracterização do Contexto Norte-Americano ……........................................................... 45

2.3. ANÁlise EnVoltóRIA DE DAdoos (DEA): ConceItos FundAMENTAIS ..........................................61

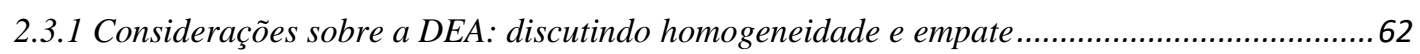

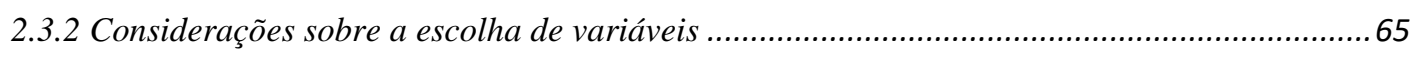

2.3.3 Considerações sobre a escolha do modelo DEA ..............................................................66

2.3.4 Modelo Slack-Based Measure (SBM) e sua demonstração matemática .....................................68

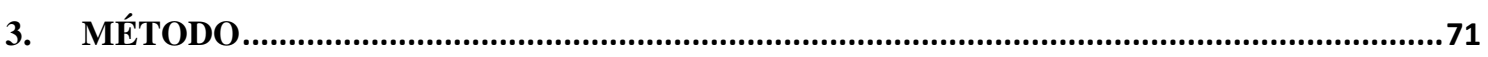

3.1. SOBRE A PESQUISA BIBLIOGRÁFICA......................................................................................... 71

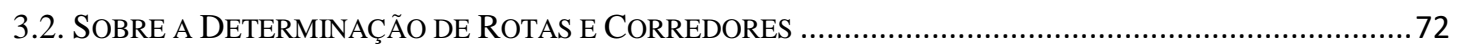

3.3. Sobre A ESCOLHA DE VARIÁVEIS E A COLETA DE DADOS ........................................................... 73

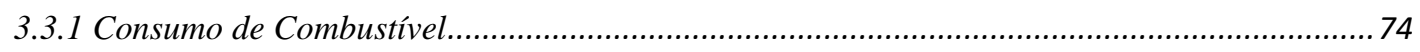

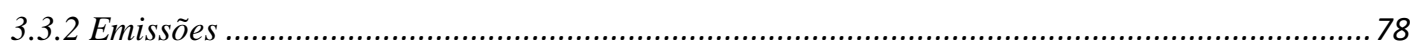

3.3.3 Capacidades estáticas de armazenamento dentro e fora das fazendas ................................... 81

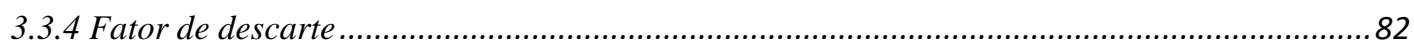

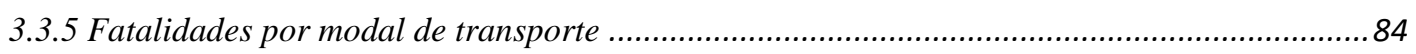

3.3.6 Área plantada

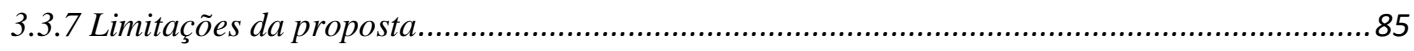

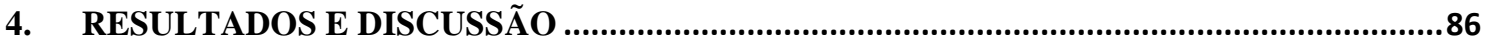

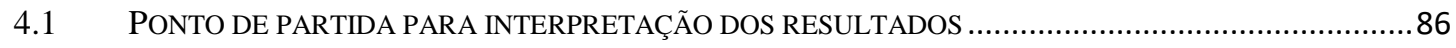

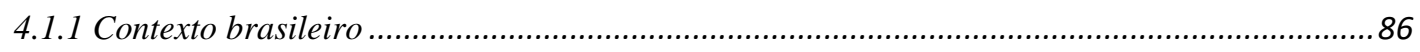

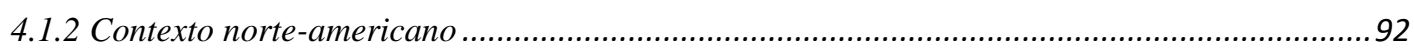

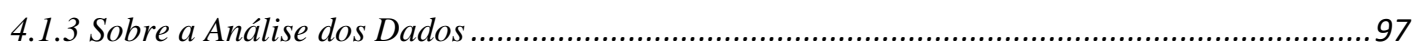

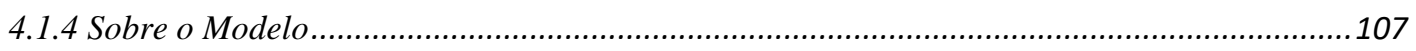

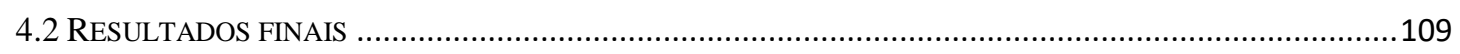

5. CONSIDERAÇÕES FINAIS ............................................................................................114

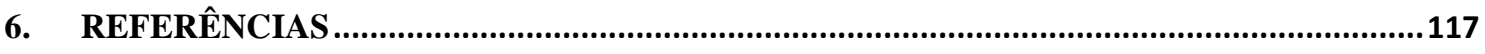

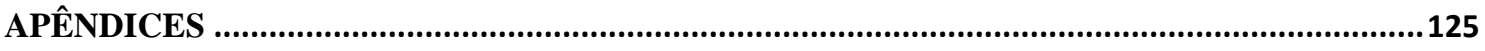

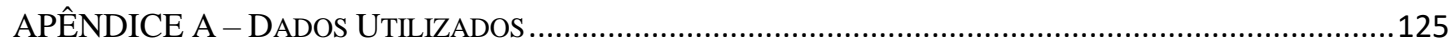

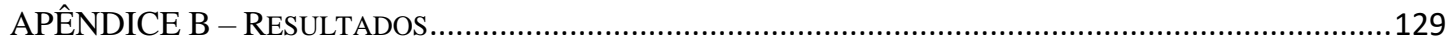




\section{Introdução}

A soja é a principal matéria-prima na produção de rações para pecuária, de óleo de soja, e de outros produtos da indústria alimentícia. O crescimento de $65 \%$ da economia global, desde 1990, contribuiu para o aumento na demanda mundial por carne, leite e ovos, que se traduziu em uma maior necessidade de soja. Isto porque, além de ser o ingrediente principal nas rações animais, também é utilizada para consumo humano direto (ESTADOS UNIDOS, 2010).

De acordo com o Ministério do Desenvolvimento, Indústria e Comércio Exterior (MDIC, 2015), a soja e seus derivados são os produtos exportados com maior participação na balança comercial brasileira $(10,98 \%$, cerca de 30 milhões de dólares em 2015). Desde 2010, a participação da soja apresenta uma curva de crescimento acentuada, enquanto outros produtos decresceram (minérios e açúcar) ou apresentam comportamento flutuante (óleos brutos de petróleo), como pode ser visto no Gráfico 1.

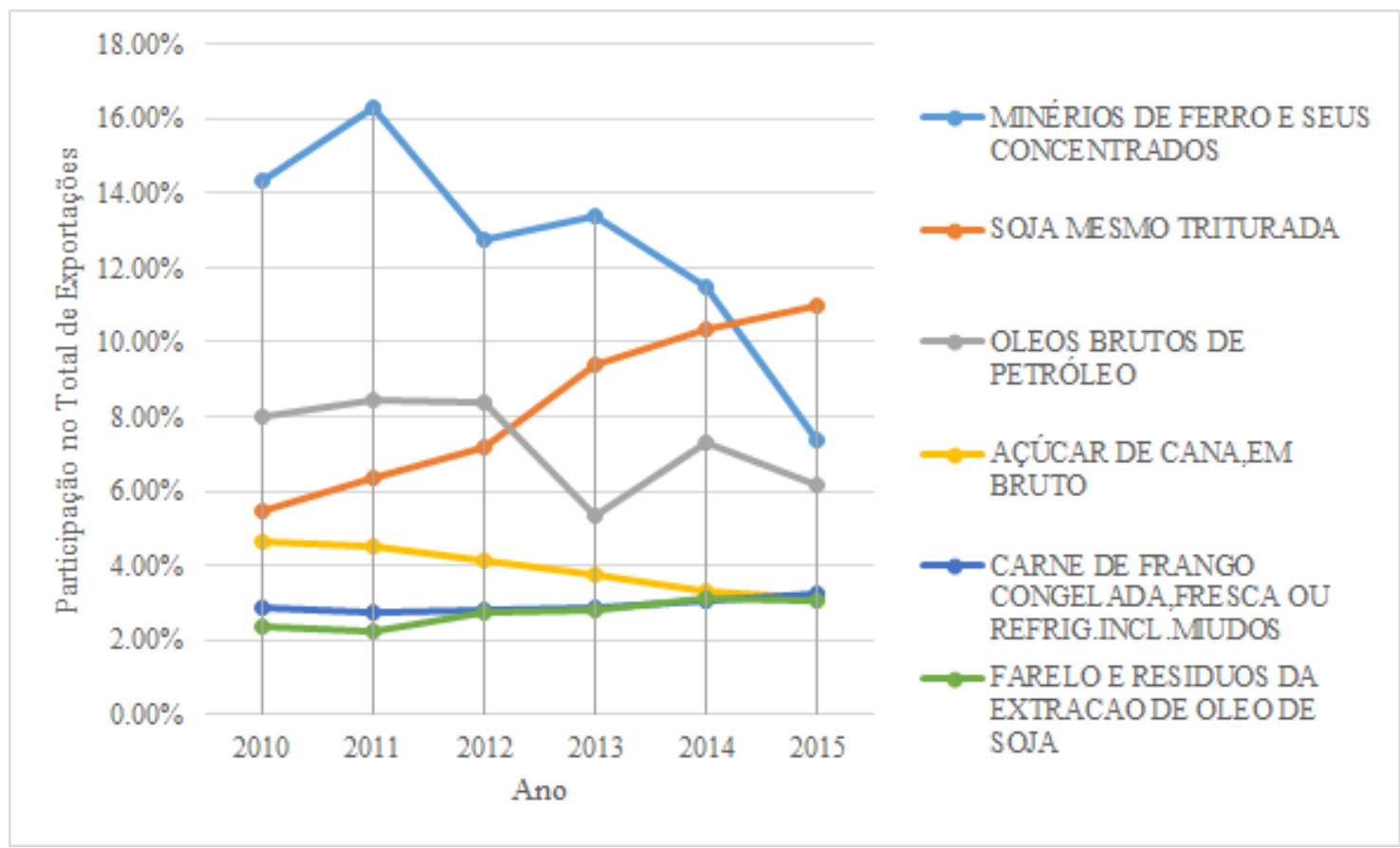

Gráfico 1 - Evolução das exportações brasileiras.

Fonte: Elaborado pela autora com dados de Ministério do Desenvolvimento, Indústria e Comércio Exterior (MDIC, 2015).

De acordo com o Bureau of Economic Analysis (2014), as exportações de alimentos para consumo humano e animal corresponderam a $9 \%$ do total das exportações norte-americanas. Nessa categoria de produtos, destacam-se: a soja $(1,6 \%$ 
do total de exportações, movimentando cerca de 25 bilhões de dólares), a carne (1,2\%, 20 bilhões) e o milho (0,5\%, 12 bilhões). Apesar de o milho ser o produto agrícola mais plantado e colhido nos Estados Unidos, ele é mais direcionado ao mercado interno.

A produção de soja movimenta um volume financeiro total semelhante, tanto nos EUA quanto no Brasil, respectivamente 25 e 30 milhões de dólares anuais. Segundo Matsuda e Goldsmith (2009), os três maiores produtores mundiais de soja são Estados Unidos (29,9\%), Brasil (21,9\%) e Argentina (15,1\%). Vale destacar que Brasil e Argentina apresentam maior projeção de crescimento em área plantada até 2030.

A soja dos Estados Unidos tem custo mais elevado porque sua moeda local é mais valorizada do que a moeda dos países competidores. Apesar do alto custo de produção, os Estados Unidos recebem mais pedidos para exportação de soja, devido às deficiências logísticas do Brasil, que levam ao não cumprimento de prazos e perdas no transporte e armazenamento dos grãos (SOUTH ATLANTA NEWS AGENCY, 2013).

Segundo Salin (2016), no período entre 2005 e 2010, a distribuição modal brasileira para o transporte de soja sofreu notáveis alterações. Dentro do território nacional, o modal de transporte para exportação e consumo interno é predominantemente rodoviário (53\%), seguido pelo ferroviário $(36 \%)$ e hidroviário (11\%). O percentual de soja transportado pelo modal rodoviário caiu $6 \%$ no referido período, enquanto o ferroviário subiu $3 \%$ e o hidroviário 4\%. Por outro lado, nos Estados Unidos, a distribuição modal para todo transporte de soja é de aproximadamente $50 \%$ rodoviário, $27 \%$ ferroviário e $23 \%$ hidroviário (INFORMA ECONOMICS, 2012). Desse modo, observa-se que a distribuição do modal de transporte de carga no Brasil está proporcionalmente se aproximando da distribuição norte-americana. Ambos têm transporte predominante por meio do modal rodoviário, seguido pelos modais ferroviário e hidroviário (SALIN, 2016).

Por sua vez, o custo de transporte na região Centro-Oeste brasileira, especialmente no Mato Grosso, é normalmente mais alto do que no estado de Iowa nos Estados Unidos, ambos maiores estados produtores de soja de cada país. Em contrapartida, o estado do Paraná, segundo maior produtor brasileiro, tem custo de transporte menor do que as rotas norte-americanas para China, por meio dos portos da região do Noroeste Pacífico, do que as rotas do Golfo Central Americano até Shangai (SALIN, 2016). Além das restrições de infraestrutura produtiva, o Brasil também sofre com baixa capacidade de armazenamento (INFORMA ECONOMICS, 2012). 
Quando analisados de uma perspectiva ampla, tanto o Brasil quanto os EUA têm uma distribuição modal semelhante para o transporte de cargas. No entanto, existem diferenças fundamentais entre esses dois países: a infraestrutura das rotas e dos corredores. Por exemplo, enquanto o Brasil tende a usar predominantemente o modal rodoviário para o transporte de cargas do produtor até o porto, ou seja, rotas que podem ultrapassar $2.000 \mathrm{~km}$ de extensão, os EUA tendem a usar o modal rodoviário para transporte de cargas para o consumo interno, ou seja, rotas entre 200 e $300 \mathrm{~km}$, em média (INFORMA ECONOMICS, 2012).

A presente pesquisa está focada no transporte de carga, por meio dos modais rodoviário, ferroviário e hidroviário fluvial, de produtores rurais até os portos exportadores. No caso, a carga escolhida foi a soja a granel e seus dois maiores produtores mundiais, EUA e Brasil. O estudo parte de uma definição das prováveis rotas mais usadas entre as principais mesorregiões produtoras dos cinco estados mais produtores até os principais portos exportadores de cada país. Isto é, são rotas estritamente domésticas e nacionais, voltadas ao mercado internacional.

Tendo em vista que o transporte de carga é a espinha dorsal do comércio internacional e a chave propulsora para a globalização (OECD, 2009) e que, além disso, as crescentes preocupações sociais e ambientais estimulam mudanças em todas as atividades humanas, inclusive a logística de carga, esta pesquisa teve por objetivo analisar, quanto à eficiência, rotas e corredores domésticos nacionais de transporte de soja, levando em consideração os três pilares da sustentabilidade (econômico, social e ambiental), por meio da método Análise Envoltória de Dados (DEA).

As perguntas que motivaram a presente pesquisa foram:

1. O Brasil pode gerir, de maneira eficiente, o transporte de soja e fazer frente à competição global apenas utilizando a infraestrutura existente?

2. Qual a distribuição modal recomendável para o transporte de soja nos corredores brasileiro?

3. Considerando o cenário atual e as projeções de crescimento do mercado, quais são os investimentos prioritários? Quais são as melhores práticas?

Dado o fato de que, os Estados Unidos são responsáveis por $41 \%$ da produção de soja mundial e que o Brasil por 40\% (MIT MEDIA LAB, 2017), mas que este presenta em desvantagem competitiva devido às restrições de infraestrutura logística (SALIN, 2016), o presente trabalho se justifica pela relevância do tema e pelo fato de que o conhecimento dos fatores de mercado de qualquer atividade econômica possibilita a 
criação de vantagens competitivas, como por exemplo, transporte por custos mais baixos, mais seguro e maior atendimento dos prazos de contrato. 


\section{Revisão Bibliográfica}

No presente tópico, tem-se por objetivo introduzir o leitor aos conceitos necessários para o entendimento do trabalho desenvolvido. O tópico está estruturado de modo que, primeiramente, as definições e conceitos básicos da infraestrutura do transporte de carga são apresentadas. Em seguida, é feita uma contextualização de cada país. Por fim, apresentar a Análise Envoltória de Dados (DEA), uma explanação de como ela pode ser aplicada dentro deste contexto, suas vantagens e limitações.

\subsection{Corredores de Transporte de Carga: estado da arte para análise de} desempenho

Embora esses termos sejam usados há séculos, não existe nenhuma definição precisa para corredor de exportação ou corredor de transporte ou o termo mais usado, em inglês, freight transportation corridor (corredor de transporte de carga). O relatório técnico de Arnold (2006) para o Banco Mundial oferece a definição que mais se encaixa com a proposta desta pesquisa. $\mathrm{O}$ autor define um corredor por suas funções físicas e funcionais. As dimensões físicas são:

- Corredores incluem uma ou mais rotas que ligam os centros de atividade econômica;

- As rotas podem ter diferentes traçados, mas têm pontos de transferência e pontos finais comuns, que são portões de acesso (termo em inglês, gateways, tradução livre) que permitem a entrada e saída de tráfego no corredor;

- As rotas são, na maioria das vezes, conjuntos de ligações e de nós que interligam serviços de transporte;

- Alguns corredores possuem um modal único, mas a maioria envolve vários modais;

- Alguns corredores são relativamente curtos e definidos por um portão de acesso principal, como, por exemplo, um porto. Outros corredores são definidos pela região que eles atendem. E alguns são definidos como parte de uma rede que atende uma macrorregião.

É importante lembrar que existem cinco modais básicos de transporte com características operacionais distintas: ferroviário, rodoviário, hidroviário, dutoviário e aéreo. Devido às suas características, cada um deles é mais adequado a um tipo de 
operação e produto. A escolha de um modal é feita por meio do equilíbrio entre aspectos de custos e características de serviços (OJIMA, 2004).

Com relação às características funcionais de corredores de transporte, Arnold (2006) aponta:

- Corredores prestam serviços de transporte e outros aspectos logísticos que promovem o comércio entre cidades e países ao longo do seu trajeto. Em muitos casos, corredores de transporte são desenvolvidos para apoiar o crescimento econômico regional;

- Corredores podem ser nacionais ou internacionais;

- Um corredor doméstico é um conjunto de rotas dentro de uma rede nacional de transporte, usada para distribuir mercadorias no interior do país. Ele inclui ligações e nós que se conectam com vários modais e com serviços;

- Um corredor de transporte internacional pode servir para o comércio exterior de um único país ou de vários países vizinhos. Pode também ligar os países que são separados por um ou mais países de trânsito ou fornecer acesso ao mar a um país sem litoral.

No caso de fornecer acesso ao mar, os corredores internacionais são caracterizados como um conjunto de corredores nacionais. Como tal, suas rotas nacionais podem ter funções concorrentes, objetivos conflituosos, múltiplas jurisdições e diferentes esquemas de financiamento. Corredores internacionais são normalmente associados ao transporte de grandes quantidades de carga e maior impacto nas economias envolvidas (ARNOLD, 2006).

Desde 2008, surgiu, na Europa, o termo corredor verde, em função do projeto EU SuperGreen, cujo objetivo é estimular o desenvolvimento de uma logística de transporte sustentável, que atenda requisitos ambientais, técnicos, econômicos, sociais e aspectos de planejamento espacial (PANAGAKOS, 2016).

O termo corredor verde carece de definições aceitas e amplamente divulgadas, assim como o termo corredor de transporte. Acredita-se que o conceito surgiu em 2012 com a publicação do livro Manual para Corredores Verdes (MOYANO et al., 2013; PANAGAKOS et al., 2013). Depois, versões condensadas desse manual apareceram com Panagakos e Psaraftis (2014) e Panagakos, Psaraftis, e Holte (2015).

Um trabalho de definição do conceito de corredor verde seria de grande utilidade para o desenvolvimento da pesquisa neste campo. Basicamente existem hoje duas 
definições para o termo: o da Comissão Europeia no Plano de Ação para a Logística do Transporte de Carga, segundo Panagakos (2016 apud European Commission, 2007) e o do Forum Sueco de Logística (NET PORT KARL SHAMN, 2012). O Quadro 1 sumariza os conceitos propostos pelas duas organizações:

Quadro 1 - Definições do conceito de corredor verde.

\section{CORREDORES VERDES}

\begin{tabular}{|c|}
\hline Comissão Europeia \\
\hline Corredores de transporte são marcados por uma \\
concentração do tráfego de mercadorias entre \\
principais centros e por distâncias relativamente \\
longas (...)
\end{tabular}

Indústria serão incentivados ao longo desses corredores de contar com multimodais e tecnologia avançada, a fim de acomodar o aumento do volume de tráfego, promovendo ao mesmo tempo

sustentabilidade ambiental e eficiência energética (...)

Corredores de transporte verdes vão ( ...) ser equipados com instalações de transbordo adequados em locais estratégicos (...) e com pontos de abastecimento inicialmente para biocombustíveis e , depois, para outras formas de propulsão ecológica (...)

Os corredores verdes poderiam ser usados para experimentar, num ambientalmente amigável, unidades de transporte inovadoras com aplicativos avançados de sistemas de transporte inteligentes (ITS).

Um acesso justo e não discriminatório aos corredores e instalações de transbordo deve ser assegurada de acordo com as regras do Tratado.
Fórum Sueco de Logística

Corredores Verdes visam à redução do impacto ambiental e do clima aumentando simultaneamente a segurança
e eficiência .

Características de um corredor verde incluem:

- soluções de logística sustentáveis com reduções documentadas de impacto no ambiente e no clima , além de alta segurança, qualidade e eficiência;

- conceitos de logística integrada com a utilização otimizada de todos os modais de transporta , assim chamada intermodalidade;

- regulamentos harmonizados com abertura para todos os atores;

- uma concentração do tráfego nacional e internacional de mercadorias no domínio dos transportes por rotas relativamente longas;

- pontos de transbordo eficiente e estrategicamente colocados , bem como uma infraestrutura com uma plataforma para desenvolvimento e demonstração de inovações logísticas, incluindo sistemas de informação, modelos colaborativos e tecnologia.

Por meio de uma comparação, nota-se que a definição sueca é a única que enfatiza explicitamente o conceito de segurança e faz referência à harmonização entre regulamentações. Embora ambas as definições mencionem a tecnologia como um fator importante, apenas a definição da Comissão Europeia menciona diretamente biocombustíveis e outras formas de propulsão. 


\subsubsection{Indicadores de Desempenho Chaves (KPIs) para Corredores}

Os indicadores de desempenho chaves (KPI, do inglês Key Performance Indicators) são ferramentas mais utilizadas para monitorar o desempenho dos corredores de transporte. O desempenho dessas unidades deve ser acessado tendo em vista as qualidades pré-especificadas, que correspondem aos objetivos que a gerência de cada corredor pretende atingir (PANAGAKOS, 2016).

Por exemplo, o indicador do projeto BRAVO (também chamado Corredor Brenner, um dos corredores europeus mais longos, que une os países nórdicos à Itália, passando pela Alemanha) prioriza pontualidade, confiança, flexibilidade, informação ao consumidor, taxa de uso das áreas de armazenamento e confiabilidade nos documentos de transporte. Por outro lado, a gestão do Corredor A (corredor comercial mais importante da Europa, que liga o porto de Rotterdam, na Holanda, ao centro industrial de Gênova no norte italiano) usa indicadores focados no volume de tráfego, quantidade de modais disponíveis, pontualidade e velocidade comercial (PANAGAKOS, 2016).

Também é possível encontrar propostas com bases mais teóricas como, por exemplo, aquelas apresentadas pelo Banco Mundial (ARNOLD, 2006). Esta abordagem usa custo, tempo, confiabilidade e flexibilidade como elementos de um indicador de desempenho para corredores. O trabalho de Ojima (2004) considera as mesmas características em sua análise de desempenho.

Segundo Panagakos (2016), um KPI deve ser relevante, quantificável, simples, claro, robusto, sensível à informação classificada e mutuamente exclusivo. $\mathrm{O}$ autor classifica os KPIs em três grupos: (i)aqueles que usam os critérios SGCI (Swedish Green Corridors Iniciative, Iniciativa Sueca para Corredores Verdes, tradução livre); (ii) os KPIs EWTC (East-West Transport Corridor, Corredor de Transporte LesteOeste, tradução livre); e (iii) os KPIs SuperVerdes (SuperGreen, em inglês).

Os critérios utilizados pelo SGCI apontam dois aspectos distintos que afetam o desempenho de um corredor: $(i)$ a estrutura que permite o provisionamento dos serviços de transporte (políticas e regulamentação, infraestrutura, questões organizacionais, etc.); e (ii) as características operacionais dos serviços de transporte (VECTURA, 2012).

Ressalta-se que o termo verde é visto puramente da perspectiva ecológica e os critérios escolhidos cobrem somente a questão ecológica e que todos os critérios relacionados a este aspecto são descritos tanto em termos absolutos quanto relativos. As medidas absolutas refletem as emissões causadas pela atividade de transporte e o 
volume do trabalho de transporte, enquanto os dados relativos descrevem a eficiência ambiental da atividade de transporte (PANAGAKOS, 2016).

Os KPIs do EWTC são superiores aos SGCI em dois aspectos: em primeiro lugar porque o termo verde combina todas as três dimensões da sustentabilidade (eficiência econômica, ambiental e social). Segundo, porque os indicadores EWTC são agrupados em operacionais e efetivos, o que facilita a análise (NET PORT KARL SHAMN, 2012; PANAGAKOS, 2016).

Os indicadores operacionais visam à otimização do fluxo de carga em trajetos curtos com respeito a todos os aspectos da sustentabilidade e direcionamento das perspectivas dos fornecedores de serviços de transportes, operadores portuários e gerentes de corredores. Os indicadores efetivos visam à otimização do desenvolvimento de uma estrutura de corredores para o longo prazo e são relevantes para os responsáveis pela manutenção e construção da infraestrutura, políticos e gerentes de corredores (NET PORT KARL SHAMN, 2012).

É importante mencionar que, ao contrário dos indicadores operacionais, os indicadores efetivos são monitorados por meio de um painel em tempo real. Este painel aponta a necessidade de eliminação dos congestionamentos que possam ocorrer tanto fora quanto dentro das regiões próximas a um corredor (PANAGAKOS, 2016).

Como terceiro e último grupo de KPIs, de acordo com Panagakos (2016), os KPIs Super Verdes foram desenvolvidos depois de um longo processo de pesquisa e catalogação dos KPIs existentes. Os Super Verdes juntam cinco grupos de KPIs (eficiência, qualidade do serviço, sustentabilidade ambiental, atendimento da infraestrutura e questões sociais), envolvendo os três pilares da sustentabilidade, com adequação à capacidade da infraestrutura, condições da infraestrutura e administração do corredor (os chamados indicadores efetivos, nos indicadores anteriores).

A primeira tentativa de construir KPIs Super Verdes resultou num aglomerado de variáveis. Os resultados iniciais foram apresentados em três eventos: dois seminários regionais com as partes interessadas, um em Nápoles, Itália, e outro na Antuérpia, Bélgica, e uma reunião de projeto com o Comitê Conselheiro da UE (União Europeia). A partir das discussões lá surgidas, criou-se o KPI Super Verde simplificado, que se limitou a oito indicadores. Destes, seis referem-se à eficiência econômica e dois referem-se às preocupações ambientais. Os aspectos sociais foram excluídos, provavelmente por ocupar um papel secundário para as partes interessadas (PANAGAKOS, 2016). 


\subsubsection{Comparação de Desempenho entre Corredores}

Ao contrário dos KPIs, estudos sobre comparação de corredores são muito raros na literatura. A maior parte dos trabalhos se limita à cadeia de suprimentos. Poucas exceções encontradas na literatura são discutidas a seguir.

O relatório do Banco Mundial (ARNOLD, 2006), Best Practice in Management of International Trade Corridors (Melhores Práticas para Corredores de Comércio Internacional, tradução livre) contém a primeira tentativa conhecida de se comparar o desempenho Caso nenhuma informação esteja disponível sobre os segmentos de mercado, grupos de commodities, tipos de transporte (granel ou contêiner) ou distribuição modal, o que normalmente ocorre, o método de Arnold (2006) começa com a construção de uma amostra. O relatório não especifica uma configuração para a amostra. No entanto, a necessidade de computar custos, tempo e confiabilidade fez Panagakos (2016) inferir que a amostra é composta de cadeias de transporte.

Depois de considerar as tendências, Arnold (2006) fez a comparação com os benchmarks (isto é, referências em boas práticas) e identificando problemas nas rotas. $\mathrm{O}$ autor não detalhou como os indicadores da cadeia foram transformados em rotas, no nível da cadeia, são transformados em rotas. No passo seguinte, problemas com as rotas foram transformados em deficiências de desempenho nas ligações e nos nós. Não houve considerações ambientais durante a avaliação e não houve tentativa de desenvolver um indicador para os níveis do corredor como um todo.

Para o Banco Mundial (ARNOLD, 2006), o custo da cadeia de transporte, nas ligações e nos nós, consiste em todo o dinheiro fora do bolso, além de custos com seguro e qualquer custo devido a acidentes com a carga durante o transporte. $\mathrm{O}$ custo referente a uma ligação pode ser descrito como uma combinação de custo fixo e variável, dependente da distância percorrida. A média do custo de transporte para a cadeia é representada na Figura 1. As linhas verticais representam os custos incorridos nos nós e qualquer custo associado ao uso da ligação subsequente. As linhas inclinadas representam o custo devido ao trânsito na ligação, sendo que a curvatura da linha é proporcional ao custo variável. 


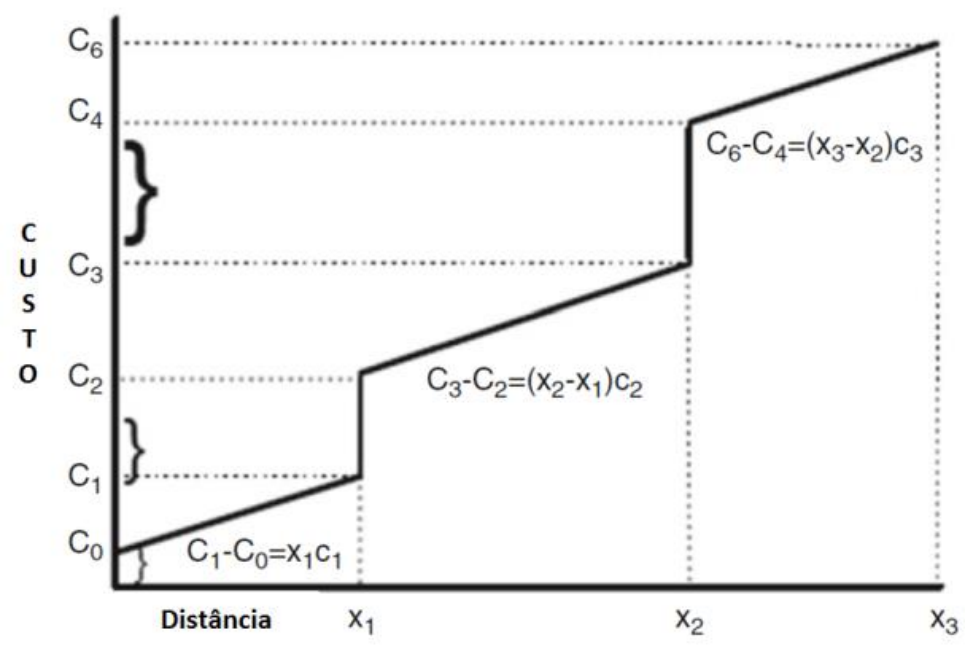

Figura 1 - Custos de um corredor com três ligações, segundo método do Banco Mundial.

Fonte: Arnold (2016).

Já o trabalho de Márquez e Cantillo (2013) desenvolve um modelo de transporte de carga, incluindo custos externos, aplicados aos sete corredores colombianos mais importantes economicamente (todos os corredores utilizando mais de um modal). Cada ligação inclui custos internos, tempo e operação e custos externos: congestionamentos, acidentes, custos ambientais (referentes à emissão de gases) e custo de infraestrutura.

Além disso, os custos marginais são calculados utilizando dois métodos. Primeiro, assumiu-se que uma unidade adicional de demanda não afeta o equilíbrio da rede de transporte, então o custo marginal é estimado como a soma dos custos marginais das ligações. De acordo com o segundo método, uma unidade adicional de demanda altera o equilíbrio do sistema; consequentemente, os custos marginais são calculados pela diferença de dois cenários de equilíbrio (MÁRQUEZ; CANTILLO, 2013).

Ambos os métodos produziram resultados similares. $\mathrm{O}$ modal rodoviário teve o maior custo externo absoluto (0,014 dólares por t-km, isto é, $37 \%$ do custo interno), seguido pelo ferroviário ( 0,0016 dólares por t-km, isto é, $12 \%$ do custo interno) e o hidroviário por meios fluviais (inland waterways) teve um custo de apenas 0,000105 dólares por t-km (isso equivale a cerca de $1 \%$ do custo interno) (MÁRQUEZ; CANTILLO, 2013). Lembrando que a unidade tonelada-quilômetro, representa aqui que é necessário (custo ou energia) para transportar uma tonelada por um quilômetro.

O método de Márquez e Cantillo (2013) abrange outros aspectos não considerados pelo método de Arnold (2006). Este método considera, além dos custos internos, os custos externos (congestionamentos e acidentes) nos nós entre ligações, além de avaliar o custo marginal para eventuais mudanças de cenário no fluxo de 
escoamento. Já o relatório para o Banco Mundial (ARNOLD, 2006) considera os custos internos, desconsiderando totalmente quaisquer custos externos e impactos de custo marginal, tanto nos nós quanto nas ligações. Mais uma vez, ressalta-se a falta de qualquer consideração ambiental em Arnold (2006).

Similarmente, o Banco Mundial também tem uma abordagem própria para calcular o tempo nas ligações e nos nós. O tempo é uma função da distância ao longo da cadeia. O tempo médio de transporte da cadeia é definido como o tempo necessário para completar as atividades essenciais de movimentação da origem até o destino da cadeia. O gráfico para o tempo é similar ao da Figura 1, sendo o tempo, ao invés do custo, representado pela coluna vertical (ARNOLD, 2006).

Portanto, cada cadeia é representada pela média de custo e tempo de trânsito. Um corredor, que consiste de diferentes combinações de rotas, modais e cadeias pode ser representado tanto pela média de tempo, quanto pela média de custos para transitar pelo corredor ou pela curva. A Figura 2 combina tempo e custo aos pares para todas as cadeias de transporte disponíveis no corredor. É consenso que uma intervenção no corredor, que melhore tanto o tempo quanto o custo, desloca a fronteira para a esquerda e para baixo.

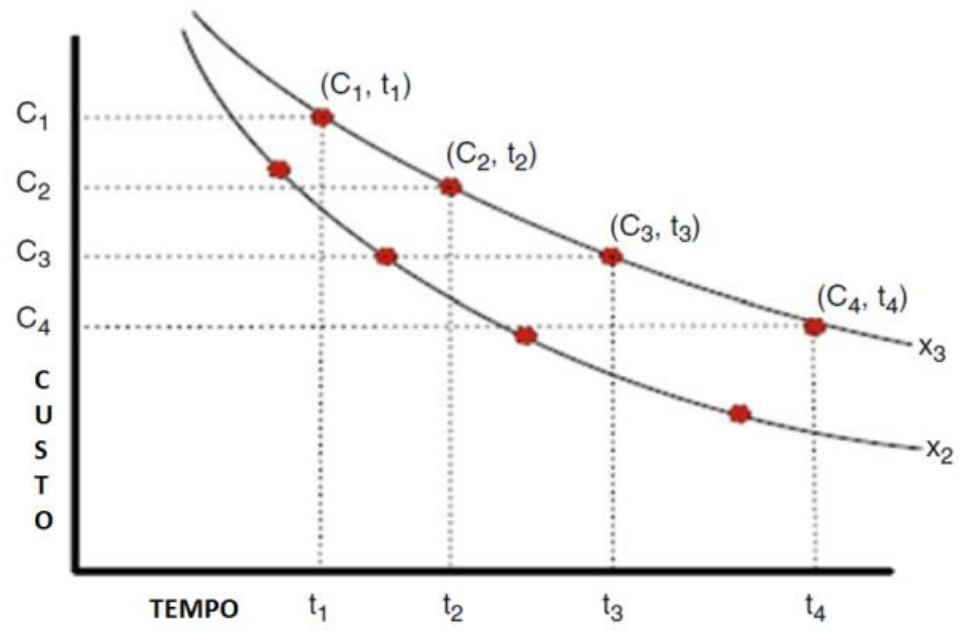

Figura 2 - Corredores de exportação representados como pares de custo e tempo por ligação.

Fonte: Arnold (2016).

Segundo Panakagos (2016 apud Kramer, 2009), o projeto BE LOGIC usou uma lógica diferente para comparar corredores, tentando acessar o desempenho do sistema de transporte de carga num nível mais estratégico, por meio de Indicadores de Desempenho Agregado (Aggregated Performance Indicators, API). No entanto, esse 
indicador é fortemente baseado em valores qualitativos, questionando sua utilidade para comparação de corredores em cenários tão diversos quanto o brasileiro e norteamericano.

Usar os indicadores SGCI da iniciativa sueca para comparar corredores pode ser uma abordagem viável; como já apresentado, esses indicadores SGCI no nível da cadeia são somados para todas as cadeias do corredor para formar KPIs no nível dos corredores. No entanto, os corredores são normalmente definidos como longas rotas, dificultando a identificação dos fluxos e serviços que precisam ser examinados. Mesmo que os corredores fossem mais precisamente melhor definidos, os dados necessários não estariam disponíveis e as aproximações gerariam erros muito maiores do que benefícios (PANAGAKOS, 2016).

Esse problema foi superado pelos indicadores EWTC. Essa metodologia recomenda a análise dos KPIs deva ser limitada a um número de serviços em todo corredor, cautelosamente selecionado (NET PORT KARL SHAMN, 2012). Esse método recomenda as seguintes considerações para a seleção dos corredores:

- $\quad$ Sempre ter em mente o objetivo da análise;

- $\quad$ Selecione as partes dos corredores com operações paralelas, permitindo o monitoramento efetivo;

- Identifique os fluxos maiores e mais estáveis, normalmente conectados às grandes indústrias;

- $\quad$ Selecione as operações de empresas que desejam compartilhar operações;

- Aproveite os sistemas de coleta de dados já existentes, incluindo sistemas relevantes de monitoramento de frotas e de pedágios;

- Foque nas dificuldades conhecidas para atingir critérios de sustentabilidade, isto é, desequilíbrio comercial, motores muito antigos, entre outras.

O método proposto pelo EWTC, em seis passos simples e práticos a seguir:

Passo 1: Defina uma meta clara para o objetivo último da análise;

Passo 2: Defina o escopo da análise em termos de objetivos secundários a serem monitorados;

Passo 3: Selecione o KPI que reflete o objetivo final da análise e serve para monitorar os objetivos secundários;

Passo 4: Selecione um sistema de fronteiras com relação a:

- $\quad$ Cobertura geográfica e fronteiras físicas do sistema a ser examinado; 
- $\quad$ As atividades e serviços de transporte que compreendem a amostra;

- $\quad$ As atividades consideradas para o cálculo do consumo de energia;

- O período de tempo coberto.

Passo 5: Coletar dados, incluindo dados secundários e a opinião de especialistas, em caso de falta de dados.

Passo 6: Calcular os KPIs.

O fator limitante do método EWTC é, conforme reconhecido pelos próprios criadores (NET PORT KARL SHAMN, 2012), comparar melhor componentes selecionados (serviços) de corredores do que corredores em si.

O método para comparação de corredores Super Verdes, desenvolvido por Zacharioudakis et al. (2013) abrange os seguintes conceitos:

- Decomposição dos corredores em cadeias de transporte;

- $\quad$ Comparação dessas cadeias usando KPIs;

- $\quad$ Agregação dos KPIs no nível da cadeia para KPIs no nível dos corredores, usando os pesos adequados para a média.

Inicialmente o método, aplicado ao caso de nove corredores europeus, incluía 11 passos:

Passo 1: Selecionar um dos noves Corredores Verdes para validar o método. O corredor com a melhor disponibilidade de dados deve ser escolhido;

Passo 2: Identificar a seção crítica desse corredor, a maior ligação que não pode ser desviada devido a restrições geográficas;

Passo 3: Analisar o fluxo de carga nesse segmento crítico (origem/destino, tipo de carga movimentada, modais usados, rotas tomadas, desequilíbrios comerciais);

Passo 4: Selecionar quatro ou cinco cargas típicas que são transportadas na ligação escolhida. Ênfase deve ser dada às cargas unitizadas, isto é, quando a carga está acomodada num volume uniforme de unidade de carga como, por exemplo, um contêiner. $\mathrm{O}$ translado da carga para diferentes modais é facilitado quando a carga está unitizada, pois é mais rápido e apresenta menor custo e protege a carga. Dado ao fato que projetos de corredores verdes priorizam a sustentabilidade, disso resulta a preferência por rotas que permitam a intermodalidade, isto é, o translado da carga por diferentes modais. A maneira mais prática para que isso ocorra é por meio da carga unitizada. 
Passo 5: Selecionar uma ou duas cadeias para cada tipo de carga selecionada. A origem e o destino da carga pode ser um par de nós dentro ou fora do corredor, uma vez que as rotas e modais mais utilizados estejam dentro do corredor. Nesse ponto, a análise se amplia de um segmento crítico para a cobertura do corredor inteiro. Todas as rotas radiais (braços) e todos os modais envolvidos devem estar cobertos. Cadeias de transporte envolvendo mais de um modal são altamente desejáveis. Para corredores onde um dos portões de acesso é um porto, as cadeias de transporte devem ser escolhidas baseadas em:

- $\quad$ Carga típica usada para cada porto de cada corredor (usar a estatística portuária);

- $\quad$ Conexões existentes entre portos e corredores;

- $\quad$ A importância relativa das conexões em termos de volume de carga;

- $\quad$ Conexões baseadas em segmentos terrestres de cada corredor;

- $\quad$ Tipos de veículos utilizados;

- $\quad$ Casos de melhores práticas identificados na literatura.

O resultado do passo 5 é um conjunto de 10 a 15 cadeias de transporte que precisam ser analisadas de acordo com os KPIs selecionados.

Passo 6: Localizar as fontes adequadas de dados para estimar os valores dos KPIs. Considerando-se que as estimativas de KPI requerem informações detalhadas sobre o tipo de veículo usado, as tecnologias aplicadas e as características operacionais da cadeia examinada.

Passo 7: Selecionar um conjunto de KPIs para cada cadeia selecionada no Passo 5. Devido ao comprimento dos Corredores Verdes, é possível ter segmentos com diferentes teores de verde ao longo de um mesmo corredor. É preferível, portanto, fazer a análise do segmento em detrimento ao corredor, quando possível.

Passo 8: Identificar obstáculos à estimação de KPIs. O processo de reengenharia de KPIs pode ser necessário para o tratamento de obstáculos. KPIs limitados por obstáculos intransponíveis devem ser descartados. É aceitável que, nesta etapa do processo, segmentos dos corredores para os quais não existem dados suficientes sejam descartados da análise atual. Espera-se que análises posteriores possam ser feitas quando houver maior disponibilidade de dados.

Passo 9: Transformar os valores de KPI estimados para o nível da cadeia num conjunto único de KPIs para o corredor. Provavelmente os pesos médios deverão ser 
usados. É essencial utilizar informações confiáveis para o peso adequado de cada variável.

Passo 10: Transformar o conjunto de valores de KPIs derivados do Passo 9 num ranqueamento de corredores únicos. Pesos relativos podem ser dados a cada KPI. É esperado que diferentes participantes da cadeia proponham diferentes pesos para esse cálculo. Uma abordagem que permita às partes interessadas atribuir livremente os pesos, conforme seus interesses, pode ser uma alternativa.

Passo 11: Uma vez que o método sugerido passe no teste de aplicabilidade com sucesso, ela pode ser aplicada aos demais corredores Super Verdes.

O trabalho de Panagakos (2016) aplicou esse método para o corredor de Brenner, o mais longo de toda Europa, e ficou evidente que a transposição do KPI no nível de cadeia para o nível de corredores seria problemática e de confiabilidade limitada devido aos seguintes fatores:

- A amostra era muito pequena (para alguns segmentos havia apenas uma observação) com cenário resultante tendo valor estatístico limitado;

- Nem todas as cadeias refletiam o transporte porta a porta, como necessário para garantir a viabilidade da comparação;

- A maior parte dos dados foi coletada por meio de entrevistas e reflete as opiniões pessoais sem validação estrita.

Então foi decidido expressar a comparação com valores dos dados da cadeia de transporte, isto é, valores mínimos e máximos dos KPIs das cadeias de transporte. A conclusão mais importante desse exercício foi mostrar a ampla flutuação de alguns KPIs. Os resultados não foram claros e coerentes como se esperava.

No Passo 10, o método inicial envolvendo a transformação de todos os KPIs num ranqueamento de corredor único provou-se demasiadamente otimista. $\mathrm{O}$ racional para esse ranqueamento era computar iterações entre diferentes grupos de KPIs (Panagakos, 2016). Mas, por exemplo, em alguns casos medidas introduzidas para melhorar o desempenho de uma área podem causar efeitos adversos em outras áreas. Essa abordagem foi considerada causadora de complicações desnecessárias, devido às seguintes razões (ibid.):

- $\quad$ Os pesos necessários para esse cálculo dependem muito da interpretação do usuário; 
- $\quad$ Trata-se de uma questão política; portanto, é melhor deixar para os políticos decidirem;

- $\quad$ Pesos, se colocados, podem levar a interpretações erradas;

- $\quad$ Pesos mudam com o tempo;

- $\quad$ Pesos podem não refletir características específicas de um país nas operações de transporte.

Segundo Panagakos (2016), os problemas encontrados por esse método, aplicado de modo piloto ao corredor Brenner (que se estende de Malmö, Suécia, até Palermo, Itália, com ligações de Salzburg, Alemanha, até Trieste, Itália, pelo eixo de Tauern, e de Bolonha, Itália, até Atenas/Tessalônica, Grécia, pelos portos gregos e italianos do Mar Adriático, vide traçado verde da Figura 3), foram intensamente discutidos no seminário SuperGreen de Napólis, Itália, em 2010. A decisão lá tomada foi o passo 10 do método. Essa decisão foi posteriormente ratificada pelo Comitê Aconselhador do projeto EU SuperGreen da União Europeia.

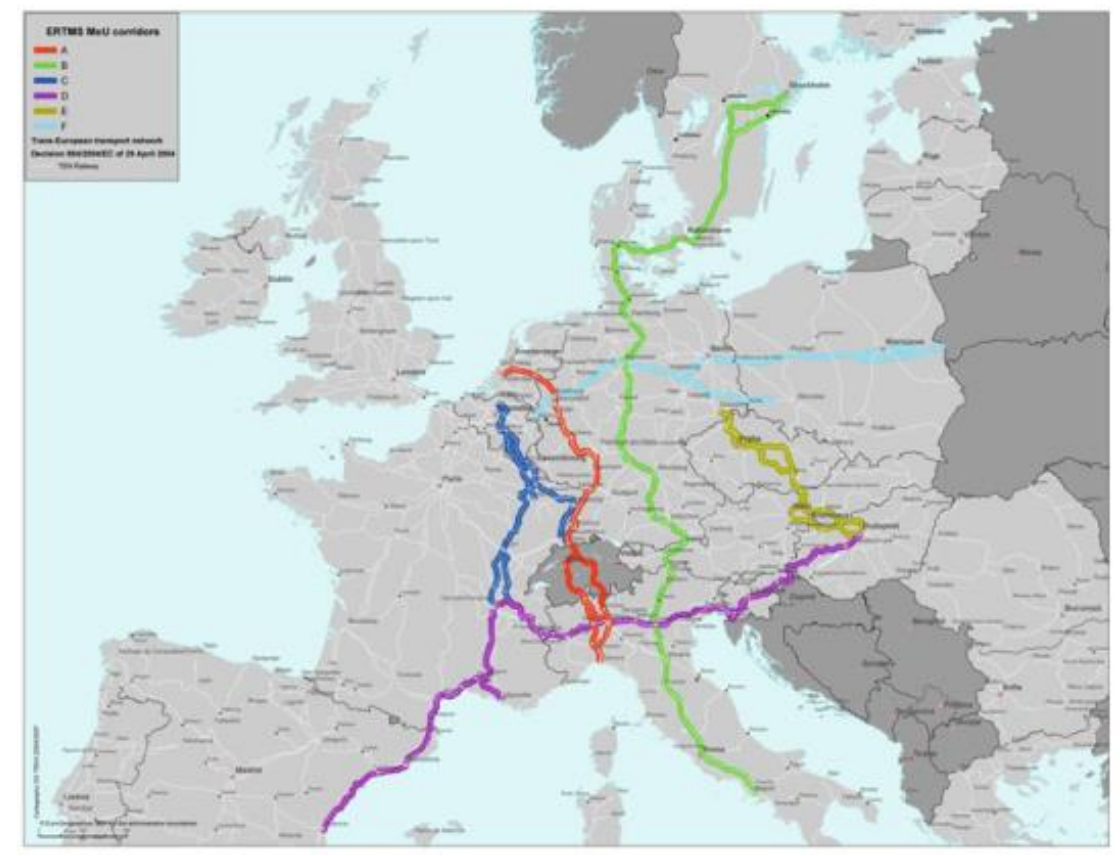

Figura 3 - Mapa dos principais corredores da Europa, incorporados pelo projeto Super Verdes.

Fonte: Panagakos (2016).

As conclusões de Panagakos (2016) foram as seguintes:

- É possível criar uma ferramenta confiável de comparação para corredores, especialmente para os Super Verdes. Contudo, tanto processo quanto KPIs 
devem ser normatizados, para que essa ferramenta se torne operacional. Mesmo assim, a comparação entre corredores será problemática, dado o fato de que nenhuma consideração pode ser dada para as características específicas de cada corredor. Por exemplo, é certo que os atributos para soluções logísticas no Mar Báltico são muito diferentes daquelas usadas para atravessar os Alpes;

- $\quad$ A construção de uma amostra de cadeias com base no escoamento dos segmentos críticos se mostrou difícil em alguns casos. Há casos em que os segmentos críticos podem ser totalmente irrelevantes para outros segmentos distantes do mesmo corredor. Outra solução deveria ser concebida;

- A coleta de dados é um sério problema. Obrigações devem ser impostas pela gestão desses corredores para coleta de dados relevantes. A formação de um grupo reduzido de participantes que atuam num determinado corredor pode ajudar para a coleta de dados, caso haja cooperação mútua entre eles. Os aplicativos ICT (Information and Comunication Technology, numa tradução livre, tecnologia da informação $e$ comunicação, tratam-se de aplicativos embarcados para comunicação e envio de dados) também fornecem dados sobre o escoamento sem causar interrupção no fluxo e outros gargalos administrativos;

- $\quad$ Agregar KPIs da cadeia para um único corredor ou segmento de corredor é possível, se e somente se, uma amostra de tamanho adequado das cadeias de transporte é examinada nas mesmas condições. Caso contrário, o uso do intervalo máximo-mínimo dos KPIs da cadeia é recomendado;

- $\quad$ Agregar KPIs para o nível de um corredor e para o ranqueamento de corredores deve ser omitido devido aos problemas associados aos pesos para esse cálculo. Como esse é um item político, é melhor deixar para os políticos decidirem.

Panagakos (2016) conclui com orientações gerais para uma comparação efetiva de corredores de transporte, baseada na experiência com Corredores Verdes. Essas orientações foram direcionais pelo presente trabalho.

\subsection{Caracterização dos Contextos Brasileiros e Norte-Americanos}

O presente subtópico explanará sobre as características de produção e escoamento no Brasil e EUA. 


\subsubsection{Caracterização do Contexto Brasileiro}

A China é o maior comprador de soja do Brasil, contabilizando cerca de $70 \%$ do total de exportações de soja em 2014. As exportações brasileiras para China normalmente começam em maio e terminam em setembro (SALIN, 2016).

Mais de $75 \%$ da soja exportada para China, em 2015, foi colhido nos estados de Mato Grosso (MT), Paraná (PR), Rio Grande do Sul (RS), Goiás (GO) Mato Grosso do Sul (MS). Os cinco estados brasileiros que mais exportaram em 2012 foram em ordem decrescente: Mato Grosso (26,87\%), Rio Grande do Sul (19,52\%), Paraná (14,30\%), Mato Grosso do Sul (6,33\%), Goiás (5,87\%) e Bahia (4,81\%) (MDIC, 2016).

A China preferia comprar soja dos portos do Sul e Sudeste do Brasil (Santos, Paranaguá, Rio Grande e São Francisco do Sul) e transportá-la via Cabo da Boa Esperança até Shangai, porque era mais barato do que comprar por meio dos portos remotos da Bacia Amazônica e do Nordeste. Por exemplo, comprando soja vinda de Santos, economizam-se de seis a oito dias de custos com navio em comparação ao porto da região de Manaus (Amazonas) e dois a três dias em comparação ao porto de Itaquí (Maranhão). Mas esse cenário está se alterando nos últimos anos. Em 2015, o porto de São Luiz (MA), foi responsável por $9 \%$ das exportações de soja. O produto era originário dos estados de fronteira agrícola (Maranhão, Piauí, Pará) e norte do Mato Grosso (SALIN, 2016).

Em 2014, o Brasil exportou soja in natura (cerca de 51 milhões de toneladas) e triturada (cerca de 14 milhões de toneladas) por meio dos seguintes portos e suas respectivas participações, sobre o total de exportações de soja: Santos (SP), 22,5\%, Paranaguá (PR), 18,8\%, Rio Grande (RS), 7,5\%, São Francisco do Sul (SC), 6,6\%, Terminal de Tubarão (ES), 5,9\%, Terminal Graneleiro Hermasa (AM), 5,6\%, Terminal Bianchini (RS), 5,5\%. Os sete portos mencionados totalizaram 72,4\% das exportações brasileiras em 2014 (ANTAQ, 2014). Em 2015, os portos de Santos (SP), Rio Grande (RS), Paranaguá (PR) e São Francisco do Sul (SC) foram responsáveis por $71 \%$ das exportações. Como mencionado anteriormente, São Luiz (MA) foi responsável por 9\% das exportações (SALIN, 2016).

Na Tabela 1, pode-se ver detalhadamente, para dados de 2015, a participação de cada porto brasileiro no escoamento da produção de soja dos principais estados produtores. 
Tabela 1 Participação relativa dos portos brasileiros no escoamento para a safra 2014/2015.

\begin{tabular}{|c|c|c|c|}
\hline Unidade Federativa & Porto & $\begin{array}{c}\text { Quantidade } \\
\text { (t) }\end{array}$ & $\begin{array}{c}\text { Participação relativa do porto, por } \\
\text { UF }\end{array}$ \\
\hline Goiás $(G O)$ & Santos (SP) & $1.850 .280,23$ & $57,40 \%$ \\
\hline Goiás $(G O)$ & Vitória (ES) & $1.072 .526,14$ & $33,30 \%$ \\
\hline Goiás (GO) & Paranaguá (PR) & $175.168,27$ & $5,40 \%$ \\
\hline Goiás (GO) & $\begin{array}{l}\text { São Francisco do Sul } \\
\text { (SC) }\end{array}$ & $106.908,90$ & $3,30 \%$ \\
\hline Goiás (GO) & Salvador (BA) & $10.294,43$ & $0,30 \%$ \\
\hline Goiás (GO) & Rio Grande (RS) & $10.016,78$ & $0,30 \%$ \\
\hline Goiás $(G O)$ & Belém (PA) & 37 & $0,00 \%$ \\
\hline Mato Grosso (MT) & Santos (SP) & $6.497 .392,70$ & $44,80 \%$ \\
\hline Mato Grosso (MT) & Vitória (ES) & $1.680 .144,58$ & $11,60 \%$ \\
\hline Mato Grosso (MT) & Barcarena (PA) & $1.615 .254,78$ & $11,10 \%$ \\
\hline Mato Grosso (MT) & Manaus (AM) & $1.133 .061,14$ & $7,80 \%$ \\
\hline Mato Grosso (MT) & São Luís (MA) & $1.027 .032,21$ & $7,10 \%$ \\
\hline Mato Grosso (MT) & Paranaguá (PR) & $846.371,82$ & $5,80 \%$ \\
\hline Mato Grosso (MT) & Santarém (PA) & $614.307,67$ & $4,20 \%$ \\
\hline Mato Grosso (MT) & $\begin{array}{l}\text { São Francisco do Sul } \\
\text { (SC) }\end{array}$ & $611.327,98$ & $4,20 \%$ \\
\hline Mato Grosso (MT) & Imbituba (SC) & $245.485,15$ & $1,70 \%$ \\
\hline Mato Grosso (MT) & Rio Grande (RS) & $213.095,09$ & $1,50 \%$ \\
\hline Mato Grosso (MT) & Aracaju (SE) & $28.727,87$ & $0,20 \%$ \\
\hline Mato Grosso (MT) & Salvador (BA) & $2.627,60$ & $0,00 \%$ \\
\hline $\begin{array}{l}\text { Mato Grosso do Sul } \\
\text { (MS) }\end{array}$ & $\begin{array}{l}\text { São Francisco do Sul } \\
\text { (SC) }\end{array}$ & $1.206 .462,77$ & $35,00 \%$ \\
\hline $\begin{array}{l}\text { Mato Grosso do Sul } \\
(M S)\end{array}$ & Paranaguá (PR) & $1.116 .962,57$ & $32,40 \%$ \\
\hline $\begin{array}{c}\text { Mato Grosso do Sul } \\
\text { (MS) }\end{array}$ & Santos (SP) & $1.049 .233,85$ & $30,40 \%$ \\
\hline $\begin{array}{l}\text { Mato Grosso do Sul } \\
(M S)\end{array}$ & Rio Grande (RS) & $72.753,15$ & $2,10 \%$ \\
\hline $\begin{array}{l}\text { Mato Grosso do Sul } \\
(M S)\end{array}$ & Imbituba (SC) & $2.057,30$ & $0,10 \%$ \\
\hline Paraná $(P R)$ & Paranaguá (PR) & $5.740 .625,13$ & $73,80 \%$ \\
\hline Paraná (PR) & $\begin{array}{l}\text { São Francisco do Sul } \\
\text { (SC) }\end{array}$ & $1.682 .368,17$ & $21,60 \%$ \\
\hline Paraná $(P R)$ & Rio Grande (RS) & $293.602,76$ & $3,80 \%$ \\
\hline Paraná (PR) & Santos (SP) & $59.012,76$ & $0,80 \%$ \\
\hline Paraná (PR) & Itajaí (SC) & $4.064,29$ & $0,10 \%$ \\
\hline Paraná (PR) & Outros & 22,11 & $0,00 \%$ \\
\hline Paraná $(P R)$ & Outros & 8,8 & $0,00 \%$ \\
\hline Paraná $(P R)$ & Outros & 2,14 & $0,00 \%$ \\
\hline Paraná (PR) & Outros & 0,02 & $0,00 \%$ \\
\hline Rio Grande do Sul (RS) & Rio Grande (RS) & $10.613 .638,52$ & $99,60 \%$ \\
\hline Rio Grande do Sul (RS) & $\begin{array}{l}\text { São Francisco do Sul } \\
\text { (SC) }\end{array}$ & $35.695,17$ & $0,30 \%$ \\
\hline Rio Grande do Sul (RS) & Paranaguá (PR) & $3.308,22$ & $0,00 \%$ \\
\hline Rio Grande do Sul (RS) & Manaus (AM) & $1.257,05$ & $0,00 \%$ \\
\hline Rio Grande do Sul (RS) & Outros & 854,4 & $0,00 \%$ \\
\hline Rio Grande do Sul (RS) & Santos (SP) & 36,02 & $0,00 \%$ \\
\hline
\end{tabular}

Fonte: Elaborada pela autora, baseado em dados de MDIC (2016). 
De acordo com os dados do Ministério dos Transportes, Portos e Aviação Civil $\left(2016^{\mathrm{a}}\right)$, o Brasil conta com 1,7 milhões de quilômetros de rodovias federais e estaduais; desse total, cerca de 12,9\% delas são pavimentadas. A extensão da malha ferroviária brasileira é de $28.190 \mathrm{~km}$ (considerando trechos devolvidos da Ferrovia CentroAtlântica - FCA). Em 2014, havia 3.340 locomotivas e 103.141 vagões responsáveis pelo transporte de mais de 140 milhões de toneladas úteis tracionadas (TUs). Segundo este relatório, estão previstos 91 bilhões de investimentos relacionados ao PIL (Programa de Investimento em Logística) nas ferrovias brasileiras nos próximos 25 anos (2014-2038). Sobre as hidrovias, o Brasil possui uma rede hidroviária economicamente navegada de aproximadamente $22.037 \mathrm{~km}$. A participação do modal aquaviário, considerando hidrovias e cabotagem, é de 13\%, sendo que as hidrovias respondem por $5 \%$ do total. As principais hidrovias são: Amazônica $(17.651 \mathrm{~km})$, Tocantins-Araguaia $(1.360$ km), Paraná-Tietê (1.359 km), Paraguai $(591$ km), São Francisco (576 km) e Sul $(500 \mathrm{~km})$. No primeiro semestre de 2014 , as hidrovias foram responsáveis pela movimentação de 38 milhões de toneladas.

A seguir é apresentada uma breve caracterização das condições das principais rotas usadas para escoar a safra de grãos em diferentes regiões brasileiras. A Figura 4 mostra o status da malha rodoviária brasileira, como um todo, ressaltando (linha vermelha grossa e contínua) aquelas que receberam investimentos diretos do Programa de Aceleração do Crescimento (PAC) em 2015. 


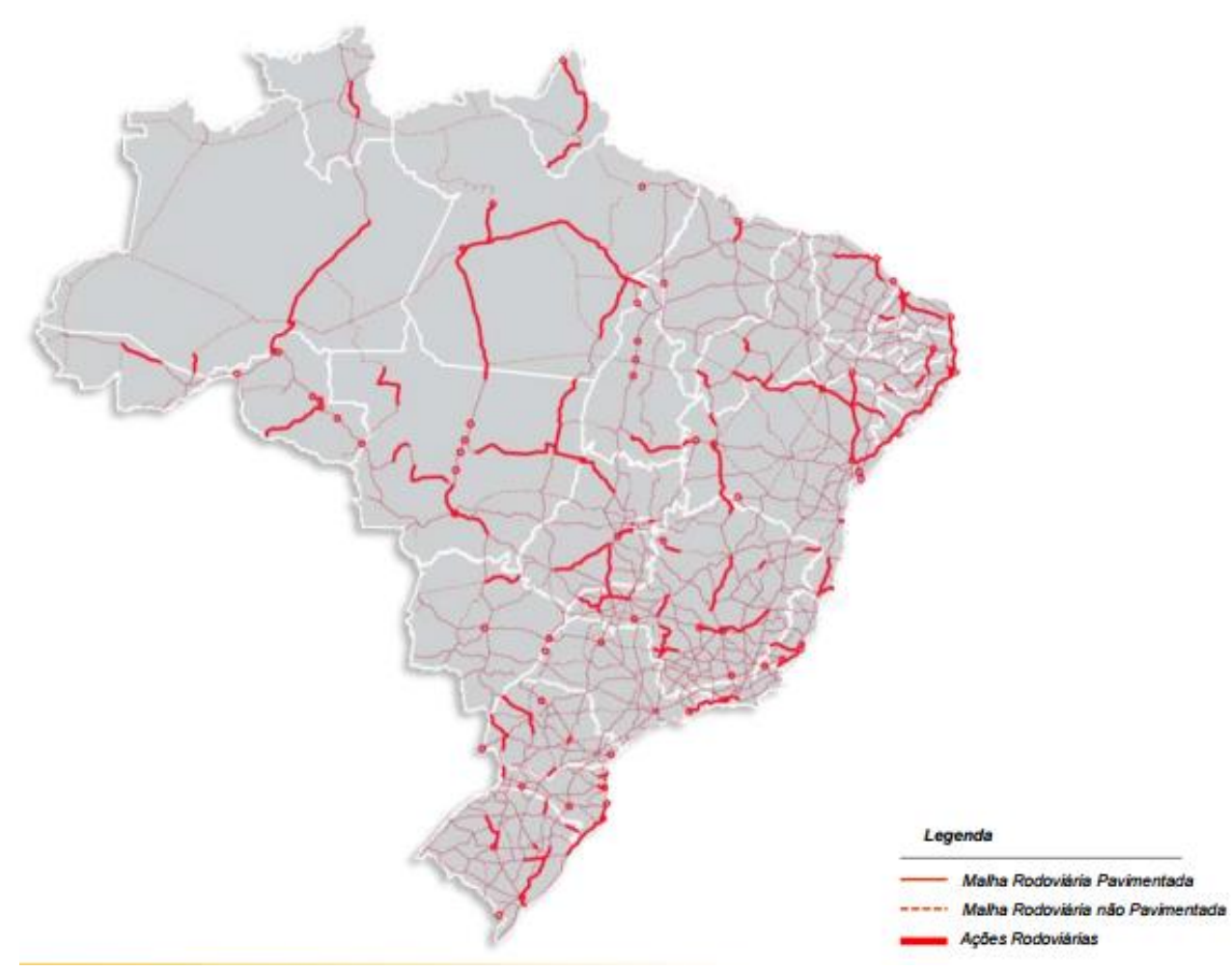

Figura 4 - Condições das rodovias brasileiras.

Fonte: Ministério dos Transportes $\left(2016^{\mathrm{b}}\right)$.

Observa-se pela Figura 4, que um veículo que parta, por exemplo, da capital de Mato Grosso, pode chegar aos portos de Santos e Paranaguá passando exclusivamente por vias pavimentadas. Também se observa que foram alvos de investimentos do PAC os trechos entre Cuiabá e Rondonópolis e toda região de entrada do porto de Paranaguá, além dos portos de Santa Catarina e do porto de Rio Grande (RS). Por outro lado, para um escoamento de produção mato-grossense para os portos da região norte (fluviais ou marítimos) ainda não é possível a realização de viagem por vias exclusivamente pavimentadas.

A Figura 5 mostra o status dos investimentos do PAC nas ferrovias brasileiras. Nesta Figura 5, uma linha que cruza todo o Brasil no sentido Norte-Sul, partindo do Rio Grande do Sul até o Pará. Esse é um projeto conhecido como Ferrovia Norte-Sul, que tem suas origens no período da Ditadura Militar. Nota-se que, até 2015, o projeto estava construído do Rio Grande do Sul até os portos fluviais do Oeste Paulista com uma ligação no sentido leste-oeste para o Mato Grosso do Sul, possivelmente utilizando a linha da antiga Ferrovia Trans Pantaneira. Observa-se também a existência de estudos preliminares para a ligação com uma possível linha em Santa Catarina. As obras estavam em andamento no estado de Goiás, ligando os portos fluviais da Hidrovia do 
Paraná-Tietê (São Simão, GO) e estavam concluídas entre Goiás e Tocantins. Nota-se que isso não significa que esse trecho da ferrovia se encontra em plena capacidade de uso, pois há necessidade da construção de uma infraestrutura de serviços e operações.

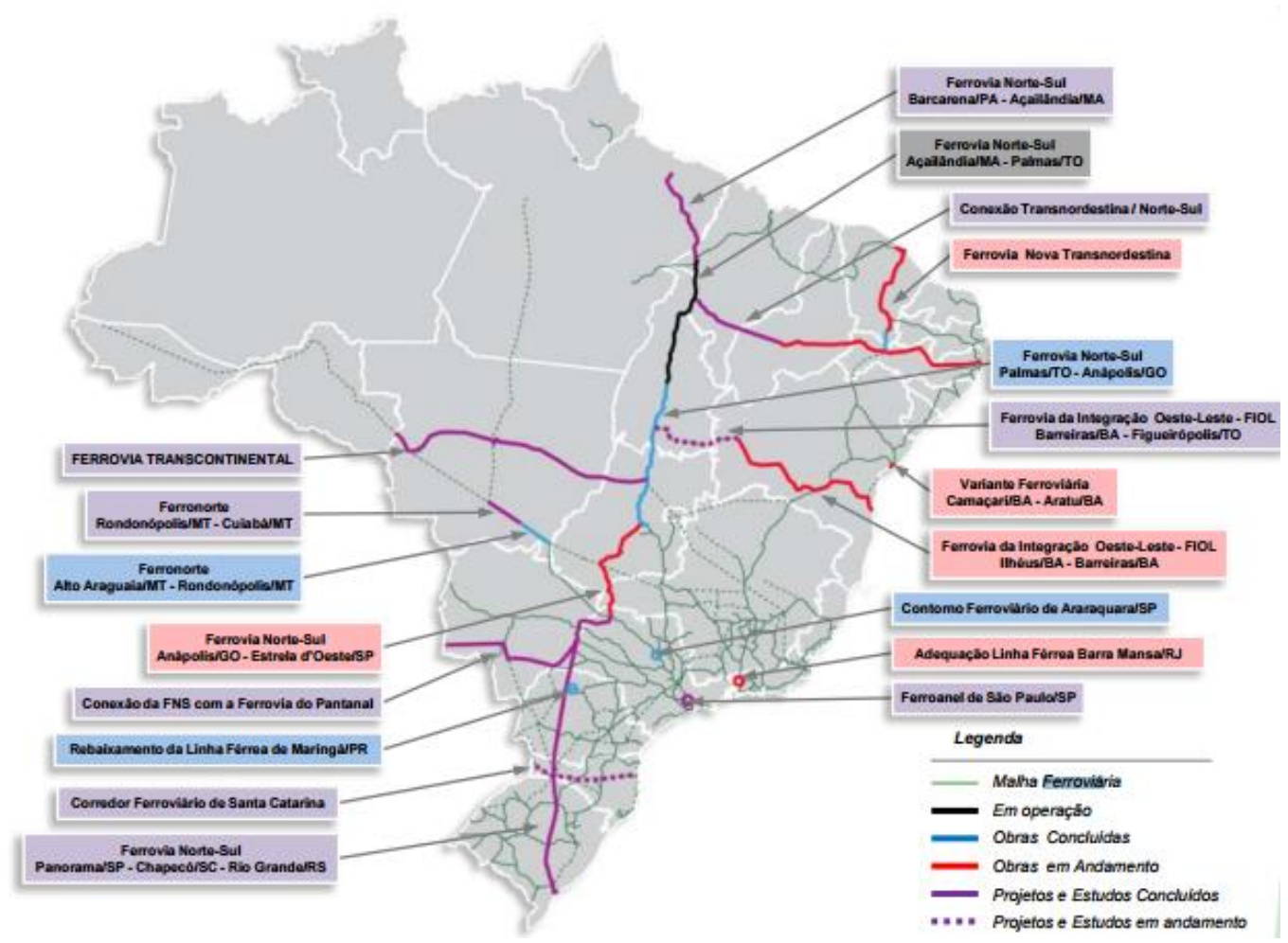

Figura 5 - Condições das ferrovias brasileiras.

Fonte: Ministério dos Transportes $\left(2016^{\mathrm{b}}\right)$.

A Figura 6 mostra o status das hidrovias brasileiras, com ênfase para aquelas que receberam investimentos do PAC em 2015. Para o escoamento da soja são cruciais a Lagoa dos Patos, a Hidrovia do Paraná-Tietê e a Hidrovia do Tapajós. 


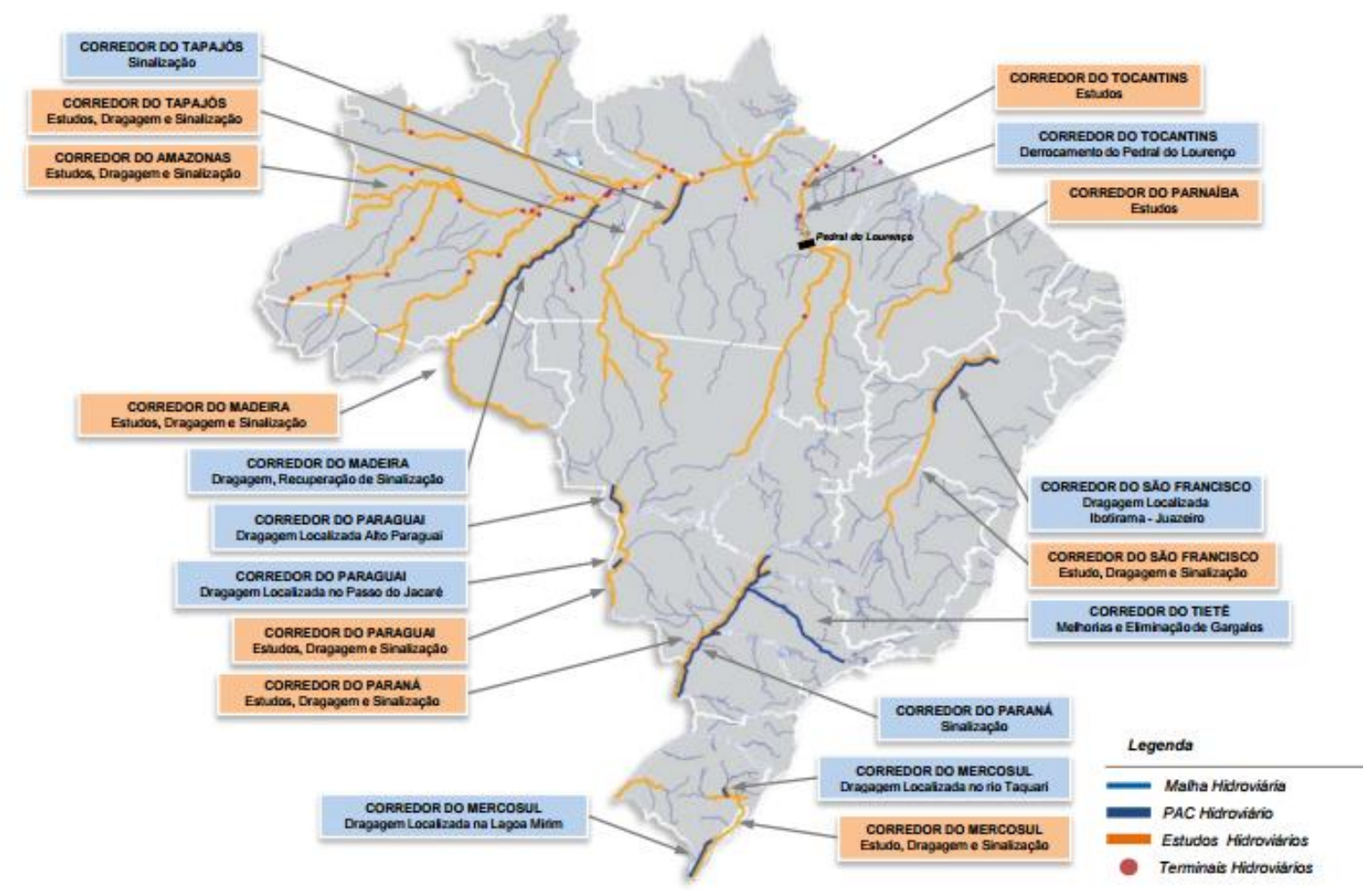

Figura 6 - Condições das hidrovias brasileiras.

Fonte: Ministério dos Transportes $\left(2016^{\mathrm{b}}\right)$.

A Hidrovia do Paraná-Tietê, indicada na Figura 6 por Corredor Paraná, permite o escoamento de Goiás até o Porto de Santos. O mapa indica que houve investimento em sinalização nessa hidrovia e que existem estudos preliminares para projetos (identificado como Corredor Paraná). A Lagoa dos Patos é descrita como Corredor Mercosul. Ela é relevante para o escoamento da produção rio-grandense, o mapa indica que houve investimentos em dragagem. Já a Hidrovia dos Tapajós está no mapa pelo nome de Corredor do Tocantins. O mapa indica um obstáculo relevante nessa hidrovia chamado Pedral do Lourenço. Trata-se de um conjunto de pedras baixa profundidade que impede a navegação de embarcações de grande calado. Segundo dados do referido mapa, o derrocamento (retirada das pedras do leito) do Pedral do Lourenço. Isso não necessariamente significa que o derrocamento foi suficiente para permitir a navegação de todos os tipos de embarcações.

Entre os principais estados produtores brasileiros, dois estão na região Sul (Paraná e Rio Grande Sul). O Rio Grande do Sul escoa quase exclusivamente pelo porto de Rio Grande (Tabela 1). O Paraná escoa principalmente pelo porto de Paranaguá e também pelo porto de São Francisco do Sul, em Santa Catarina (Tabela 1).

A Figura 7 mostra a localização e alguns detalhes da Hidrovia Jacuí-Lagoa dos Patos, também chamada de Hidrovia do Sul ou Corredor Mercosul. 


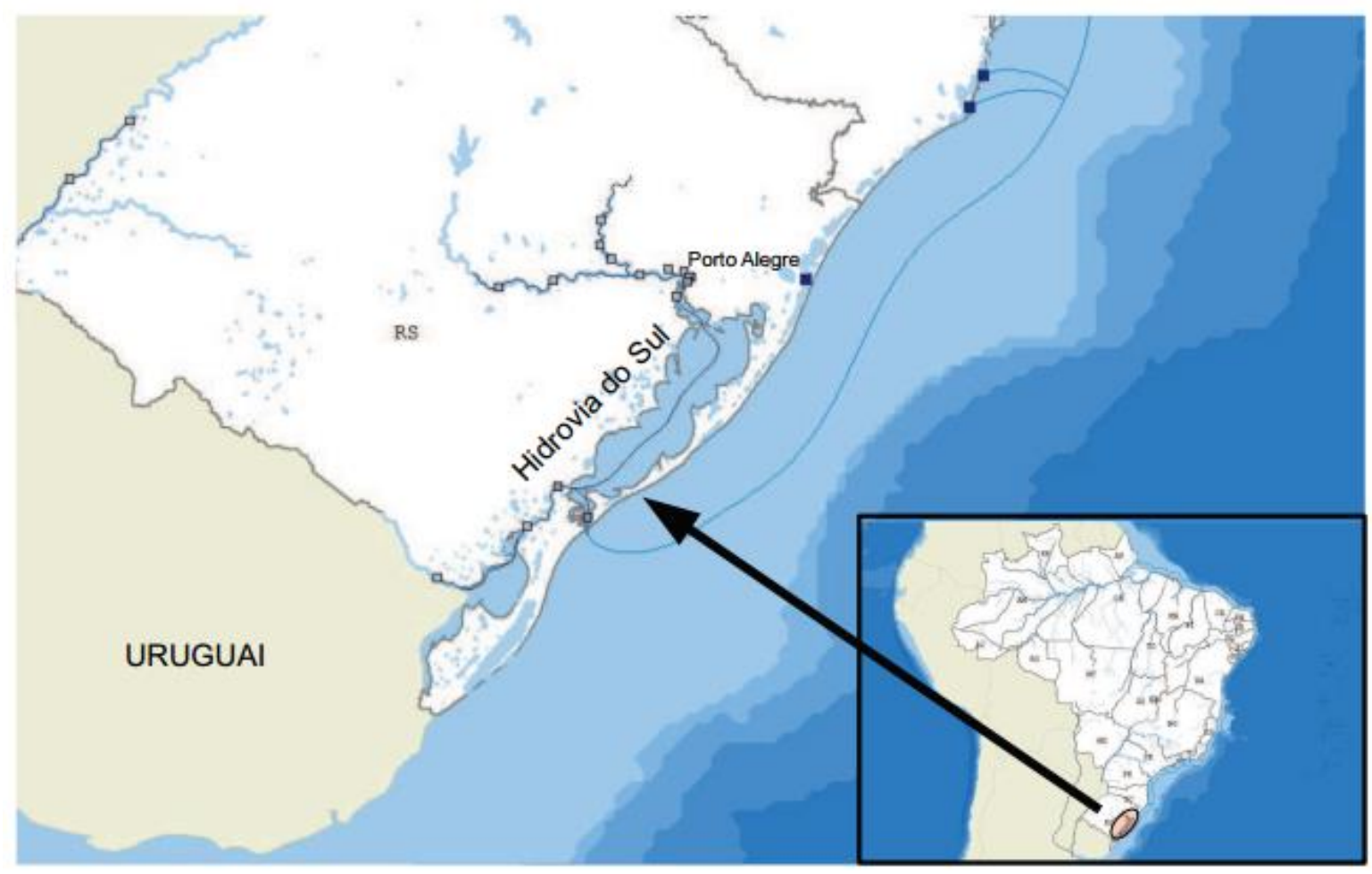

Figura 7 - Localização da Hidrovia Jacuí-Lagoa dos Patos.

Fonte: ANTAQ (2011).

Como pode ser visto na Figura 7, no Rio Grande do Sul, há a BR-386 e a BR153 até o Porto de Rio Grande (RS). No Paraná, há a BR-376 e a BR-277 que ligam os centros produtores aos consumidores e aos portos de Paranaguá (PR) e de São Francisco do Sul (SC). O Rio Grande do Sul também conta com a Hidrovia Jacuí - Lagoa dos Patos (também chamada de Corredor Mercosul), que interliga os centros produtores até o Terminal Hidroviário de Porto Estrela (RS) ao Porto de Rio Grande, pela Lagoa dos Patos (SPH, 2016). Essa hidrovia tem características peculiares, quando comparada às demais hidrovias brasileiras. De forma semelhante às hidrovias europeias, o sistema hidroviário gaúcho liga (por meio de rios, canais e lagoas) as regiões industriais e de produção agrícola até um grande porto marítimo (Rio Grande), já na saída para o Oceano Atlântico (ANTAQ, 2011).

A Figura 8 detalha as principais malhas ferroviárias que atendem as regiões Sul e Sudeste do Brasil. A região Sul tem uma malha ferroviária relativamente consolidada, em comparação com as demais regiões brasileiras. Ambos os estados contam com as operações da empresa RUMO ALL (2015), a Figura 8 ilustra a malha ferroviária desta companhia. Deve-se fazer a ressalva de que o mapa está desatualizado, pois atualmente a linha do Mato Grosso chega até Rondonópolis (MT) (PETROLI, 2014). 


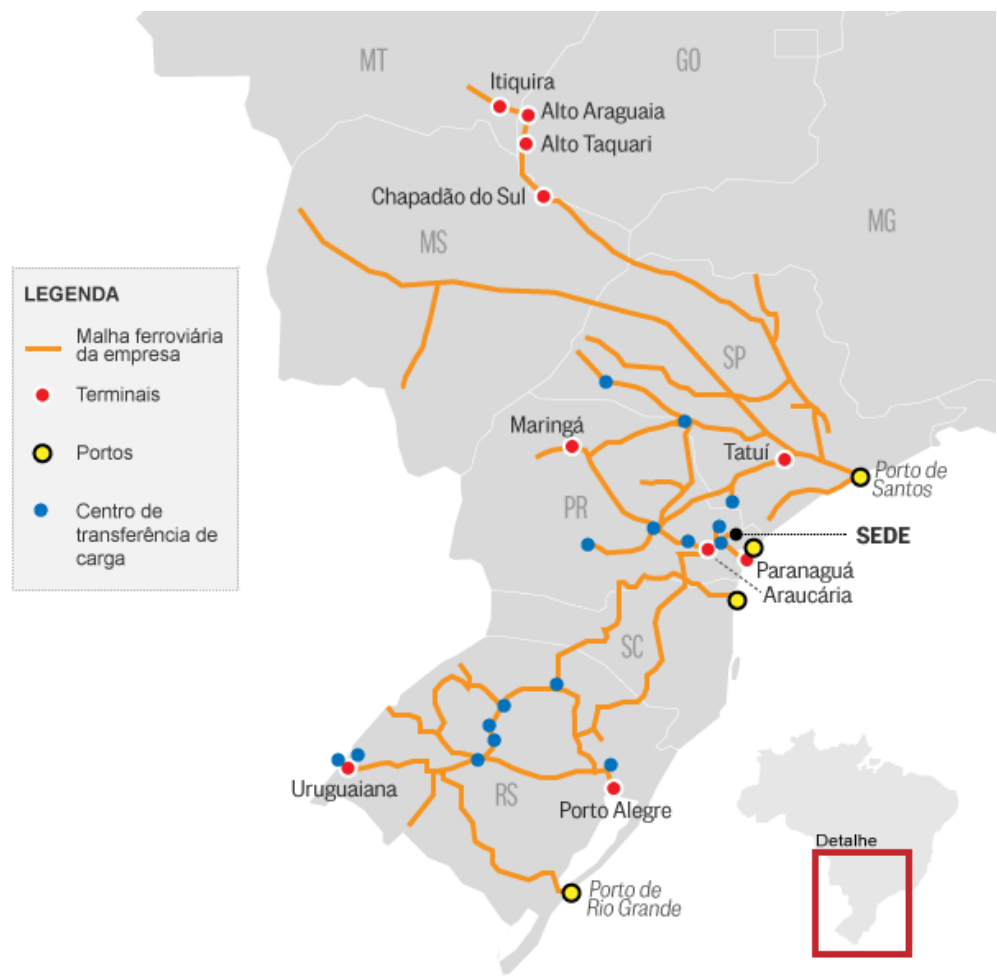

Figura 8 - Malha ferroviária da empresa.

Fonte: RUMO ALL (2015).

O Paraná também conta com a curta malha $(248,6 \mathrm{~km})$ da empresa estatal Ferroeste, que liga os municípios Cascável e Guarapuava (dois grandes produtores agrícolas) para, em seguida se conectar com as linhas da RUMO ALL (FERROESTE, 2016).

A região Sul é o ponto de partida do projeto Ferrovia Norte-Sul, que ligará o porto de Rio Grande (RS) ao porto de Barcarena (PA), com mais de $4.000 \mathrm{~km} \mathrm{de}$ extensão. Segundo o Ministério dos Transportes $\left(2016^{\mathrm{b}}\right)$, a ferrovia está construída no trajeto que liga Rio Grande a Santa Bárbara d'Oeste (SP). A Figura 8 ilustra a rota planejada da Ferrovia Norte-Sul e o status das obras em cada região. Ressalta-se a conexão com o município de Panorama (SP), que é um terminal hidroviário da Hidrovia Paraná-Tietê (AHRANA, 2012). Dessa forma, a Ferrovia Norte-Sul pode interligar a Hidrovia Jacuí-Lagoa dos Patos com a Hidrovia Paraná-Tietê.

A Figura 9 apresenta, com detalhes, o projeto da Ferrovia Norte-Sul. Entre os estados atendidos pelo escopo desta pesquisa estão os da região Centro-Oeste (Mato Grosso, Mato Grosso do Sul e Goiás). Essa região tem grande potencial de ser atendida pela Ferrovia Norte-Sul. Nota se que a linha termina no porto de Barcarena no Pará (as 
margens do Rio Amazonas), os estudos de projetos estão concluídos até Açailândia no Maranhão (que também é uma região de fronteira agrícola). A ferrovia encontra-se em operação de Açailândia até Palmas, capital do Tocantins, e as obras estão concluídas de Palmas até Anápolis, Goiás. Caso, todo esse trajeto estivesse concluído, isso permitiria o escoamento da produção goiana pelos portos da região Norte com custo mais baixo do que o cenário atual.

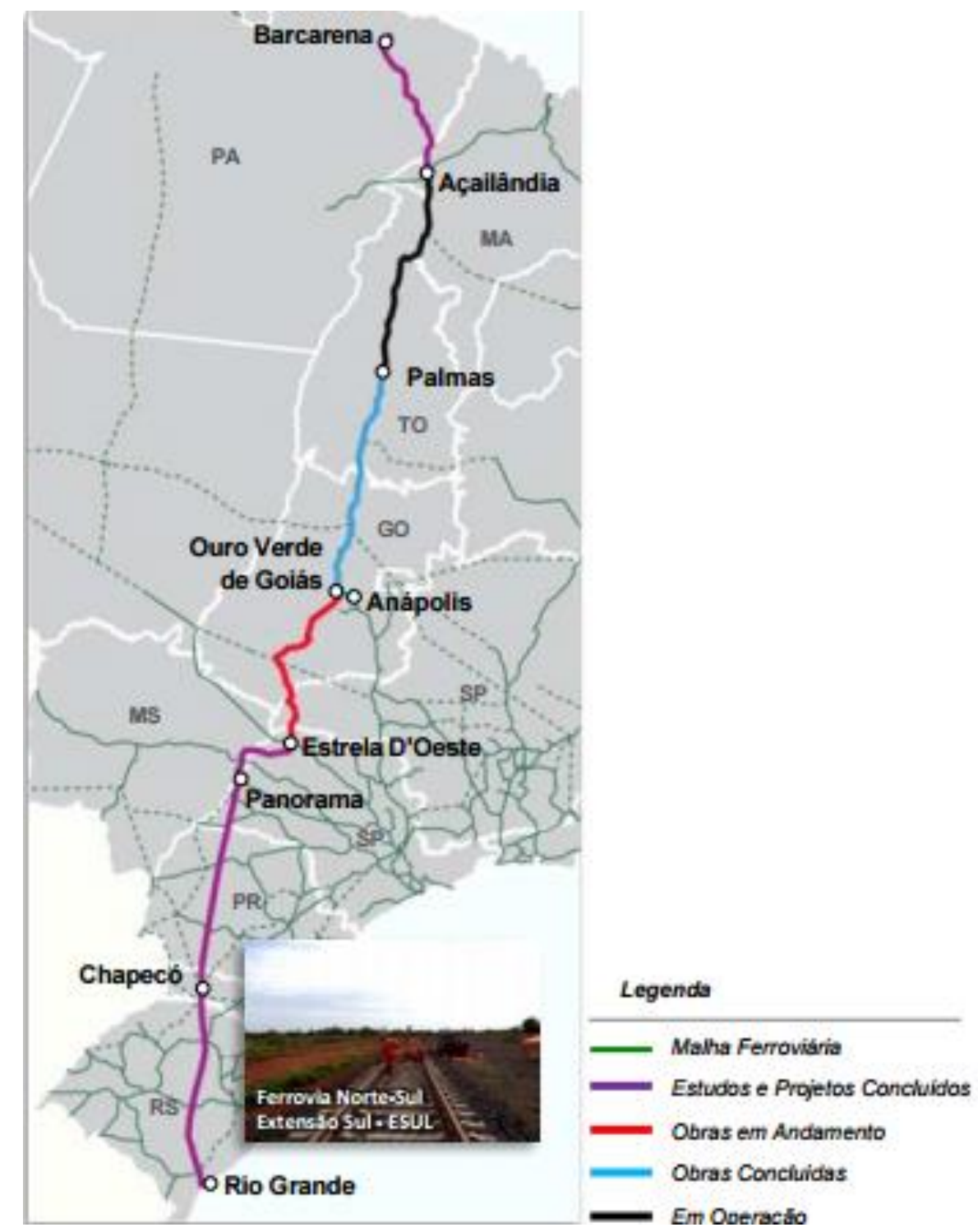

Figura 9 - Condições das obras na Ferrovia Norte-Sul.

Fonte: Ministério dos Transportes $\left(2016^{\mathrm{b}}\right)$.

Além dos estados sulistas, os demais produtores no escopo deste projeto estão na região Centro-Oeste, que não tem acesso ao oceano e, portanto, não possui portos. Embora a discussão sobre um projeto de construção de uma ferrovia que ligue o Brasil 
ao Oceano Pacífico, passando pelo Peru, seja atual e recorrente na mídia especializada (OLIVEAU, 2016). Ainda não existe nenhuma rota consolidada para o oceano Pacífico.

Como pode ser observado pelos dados da Tabela 1, o escoamento da produção da região Centro-Oeste para o oceano Atlântico se dá por portos nas regiões Sudeste $(57,35 \%)$, Sul $(21,73 \%)$, Norte $(15,87 \%)$ e Nordeste $(5,04 \%)$. Este estudo se a estudar apenas o escoamento por meio das regiões Sul e Sudeste porque respondem por quase $80 \%$ do escoamento total do país. Embora sejam frequentes as discussões sobre os projetos de investimento em infraestrutura que desenvolvem o escoamento pela região Norte, como, por exemplo o Corredor Norte-Sul (SALIN, 2016; Ministério dos Transportes, $2016^{\mathrm{b}}$ ), esta dissertação optou por não abordar esta questão devido à escassez de dados.

As principais rodovias do Centro-Oeste são a BR-163 e a BR- 364. A primeira liga as áreas produtoras do Mato Grosso ao porto de Paranaguá (PR). Já a BR-364 interliga o Mato Grosso e Mato Grosso do Sul a Rondônia e também ao Porto de Santos (SP). Como parte de reorientação do escoamento da produção regional, foram concluídos recentemente o prolongamento e a pavimentação das rodovias BR-070 e BR-174, no sentido de Cuiabá (MT) a Porto Velho (RO). A região Centro-Oeste foi mais intensamente afetada pelo programa de concessão de rodovias, sendo que suas principais rotas de escoamento para o Sul e Sudeste já foram leiloadas e, em dezembro de 2015, estava na última fase o leilão da BR163/230 MT/PA, que liga o município de Sinop (MT) a Miritituba (PA), para o escoamento de soja pelos portos da região Norte (Ministério dos Transportes, 2016 ${ }^{\mathrm{b}}$ ).

$\mathrm{Na}$ região Sudeste, há diversas rodovias, entre elas, a BR-060 que liga o Triângulo Mineiro até São Paulo. Esta última fez parte do PIL, programa de parceria público-privada que concedeu as rodovias para as empresas da iniciativa privada, sob a condição de realizar melhorias das rodovias implantadas, principalmente para a ampliação e pavimentação das estradas. O status desses investimentos foi apresentado pelo relatório do Ministério dos Transportes $\left(2016^{\mathrm{b}}\right)$.

Para se chegar aos portos da região Sul partindo-se da região Centro-Oeste há duas alternativas viáveis: cruzando-se a região Sudeste, especificamente o Triângulo Mineiro e o noroeste paulista, ou alcançando o extremo sul de Mato Grosso do Sul e o extremo noroeste do Paraná, trajeto da BR-163. O trecho sul mato-grossense dessa rodovia não consta como privatizado nem como foco de investimentos governamentais. O trecho paranaense não consta como privatizado, mas consta como foco de 
investimentos governamentais, o que pode ser observado na Figura 4 (Ministério dos Transportes, $2016^{\mathrm{b}}$ ).

O sul do estado de Mato Grosso e o sudoeste de Goiás é atendido por uma única linha ferroviária. A unidade federativa de Mato Grosso do Sul é atendida por uma única linha que bifurca, atendendo norte e sul do estado. Os terminais de Mato Grosso estão em Rondonópolis e Itiquiri, os de Goiás, em Alto Araguaia e Alto Taquari e os de Mato Grosso do Sul, em Chapadão do Sul (Figura 8).

A principal hidrovia que atende o Centro-Oeste é a Paraná-Tietê. Ela é gerida por uma agência estatal, a Administração da Hidrovia do Paraná (AHRANA). A hidrovia se estende por $1.020 \mathrm{~km}$. Para identificação, a rota de navegação a hidrovia foi dividida em quatro trechos, conforme descrito abaixo e ilustrado na Figura 10:

- O Trecho 1 da Hidrovia está situado entre a UHE de Itaipu e a entrada do Canal de Navegação, sob a Ponte Rodoviária Ayrton Senna, apresentando profundidades que variam entre $10 \mathrm{~m}$ e $180 \mathrm{~m}$, com extensão de $170 \mathrm{~km}$;

- O Trecho 2, com extensão de $245 \mathrm{~km}$, estende-se desde o Canal de Navegação sob a Ponte Rodoviária Ayrton Senna até a UHE Eng. ${ }^{\circ}$ Sérgio Motta (Porto Primavera);

- O Trecho 3, com extensão de $270 \mathrm{~km}$ e totalmente situado no reservatório da UHE de Eng. Sérgio Motta;

- O Trecho 4, com extensão de $225 \mathrm{~km}$, apresenta boas condições de navegação desde a foz do Rio São José dos Dourados até o Complexo Portuário de São Simão (GO), com o percurso de 55km no Rio Paraná, 170 km no Rio Paranaíba e 80km no Rio Grande (trecho IV-A). 


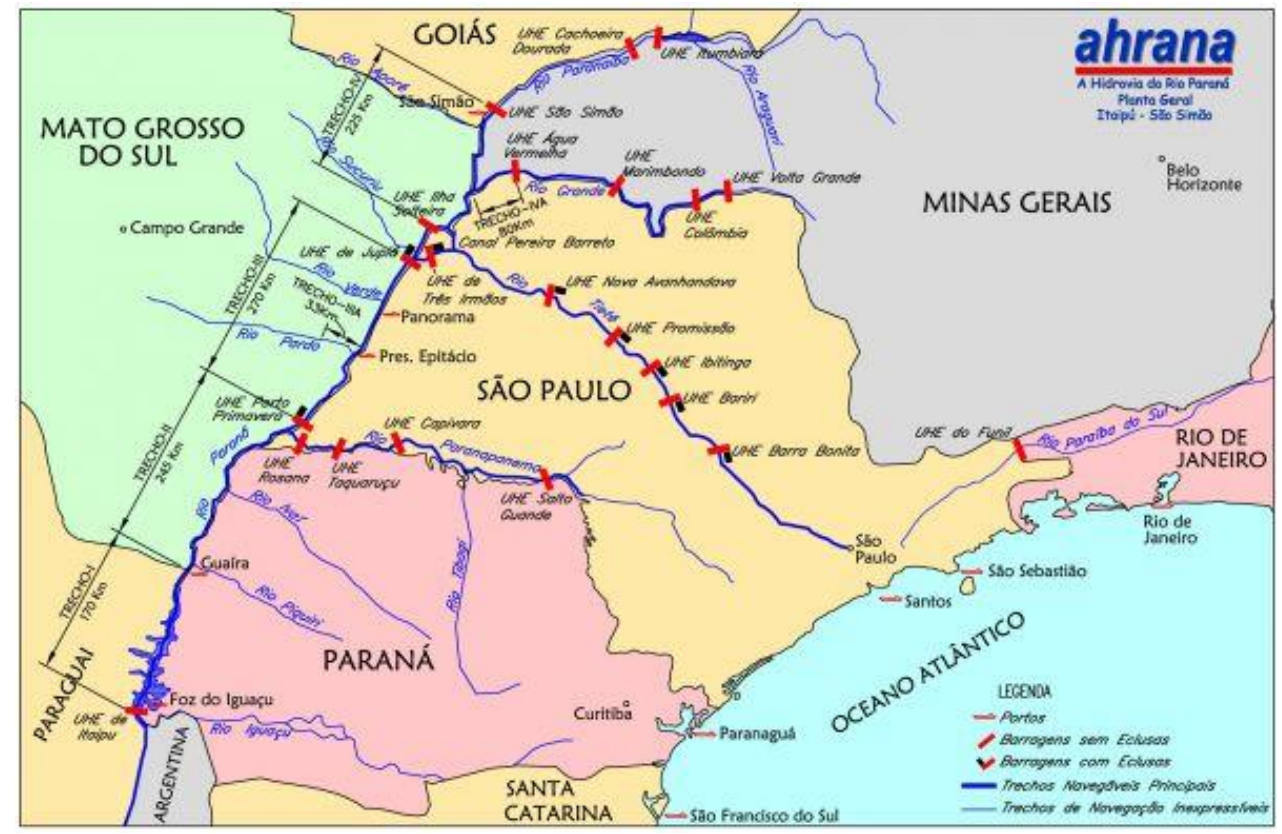

Figura 10 - Mapa da Hidrovia Tietê-Paraná.

Fonte: AHRANA (2016).

Na Hidrovia do Paraná-Tietê, em média, 60\% das cargas transportadas, têm como destino o trecho do Tietê e $40 \%$ são dirigidas à bacia do Rio da Prata na Argentina. Esta hidrovia é utilizada para o transporte de grãos da região Centro-Oeste, principalmente para a produção do estado de Goiás, com destino ao terminal hidroviário de Pederneiras (SP), Anhembi (SP) e Santa Maria da Serra (SP), seguindo destes terminais até o Porto de Santos (SP) (AHRANA, 2012).

A maior restrição do modal hidroviário é sua dependência das variações climáticas; durante secas prolongadas, como as vividas em 2010, o leito dos rios abaixa e as hidrovias não operam plenamente (AHRANA, 2012).

\subsubsection{Caracterização do Contexto Norte-Americano}

Entre 2000 e 2006, o transporte da soja correspondeu a $20 \%$ de todo transporte de grãos nos Estados Unidos. Esse escoamento possui uma estrutura logística similar ao do milho: os modais ferroviário e hidroviário são responsáveis pelo transporte para exportação e o modal rodoviário serve majoritariamente ao mercado doméstico. Desde 2004, o percentual de soja exportada pelo modal ferroviário vem aumentando, enquanto o percentual hidroviário vem decaindo levemente. De fato, em 2006, o uso do modal hidroviário era apenas 3\% maior que o ferroviário (ESTADOS UNIDOS, 2010). 
A soja norte-americana é exportada principalmente pelos portos do Complexo do Mississipi (63\%), também chamado de Golfo Central, e do Complexo do Noroeste Pacífico (17\%), abreviado como PNW, entre os estados de Washington e Oregon, mais próximo da China (SALIN, 2016). O aumento da utilização do modal ferroviário se deve principalmente ao maior escoamento de grãos por meio do PNW (INFORMA ECONOMICS, 2012).

Segundo Informa Economics (2012), considerando a produção de $2010 \mathrm{em}$ toneladas métricas, os maiores estados americanos produtores de soja são Iowa $(14,5$ milhões), Illinois (13 milhões), Minesota (8,5 milhões), Indiana (8 milhões), Nebraska (7,8 milhões), Missouri (6,9 milhões), Ohio (6,6 milhões), Dakota do Sul (5,2 milhões). Os nove estados produtores restantes produziram juntos 24,5 milhões de toneladas em 2010.

O sistema ferroviário norte-americano se caracteriza pela troca de trens menores, que percorrem distâncias relativamente curtas, por trem com comboios de vagões muito maiores, que percorrem distâncias continentais. Essa mudança ocorreu devido ao deslocamento da produção agrícola para oeste do Cinturão do Milho. Assim, um terço dos trens tem mais de 100 carros. Eles eram menos de $15 \%$ em 2003. O principal destino do modal ferroviário é exportar por meio do PNW (cerca de 340 mil toneladas de grãos foram exportadas em 2014), sendo os outros destinos as regiões Sudeste e Sudoeste, principalmente Texas e Oklahoma (INFORMA ECONOMICS, 2012).

A Figura 11, sem escala, mostra as conexões ferroviárias até os principais portos da Costa Oeste e as principais empresas operadoras (Burlington Northern and Santa Fe - BNSF, Union Pacific - UP e Puget Sound and Pacific - PSP). Segundo a Association of American Railroads (ESTADOS UNIDOS, 2015), a malha ferroviária denominada Class I corresponde a $69 \%$ de todo transporte ferroviário do país, estando suas rotas presentes em 44 estados e se caracterizando por rotas longas e cargas mais pesadas. 


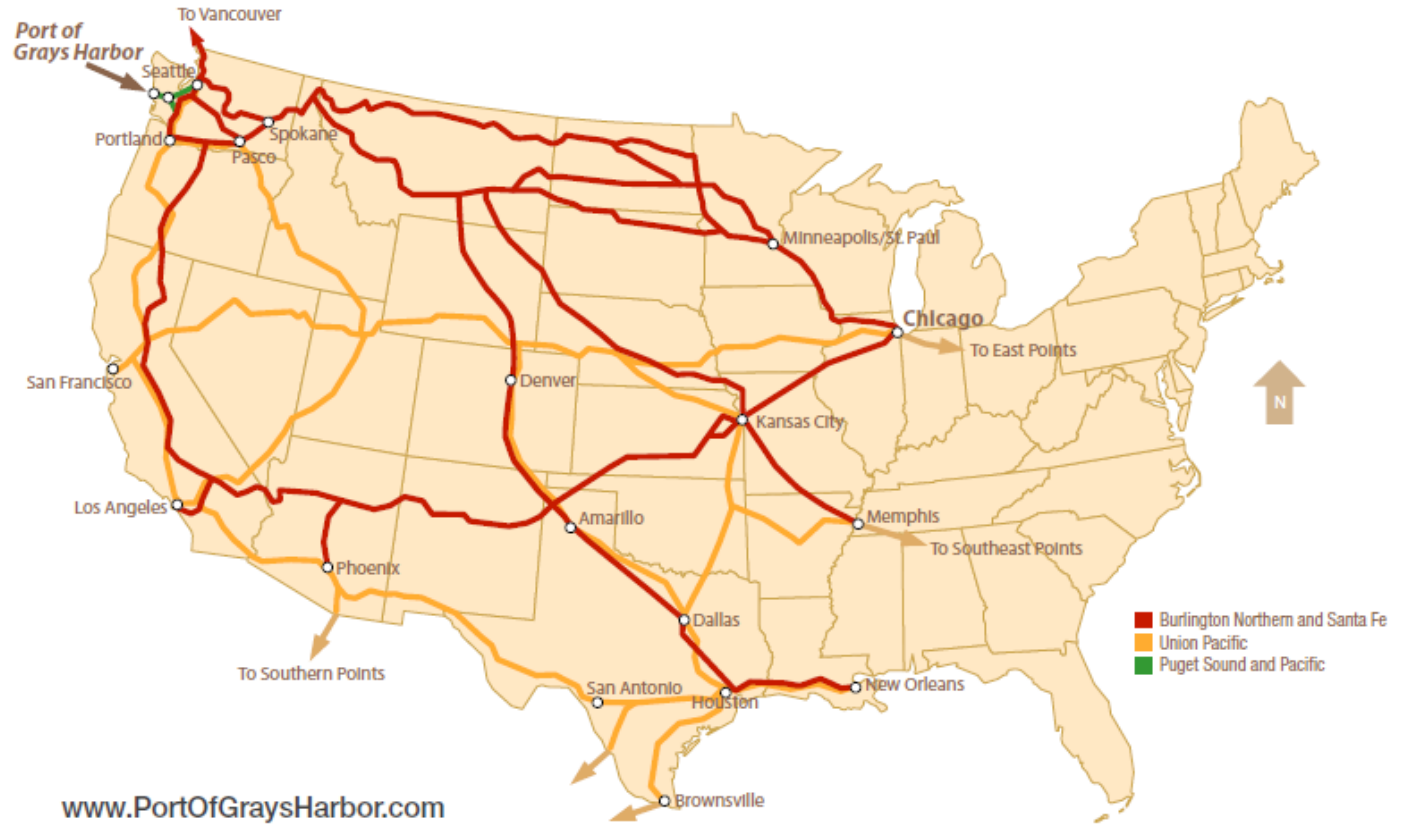

Figura 11 - Conexões ferroviárias para o PGH, porto especializado em exportação de grãos. Fonte: Port of Gray Harbour (2016).

De acordo com Informa Economics (2012), as hidrovias significativas para o transporte de grãos são o Sistema do Alto Rio Mississipi, o Sistema do Baixo Rio Mississipi e o Sistema do Rio Ohio. Os EUA têm uma extensa rede de hidrovias fluviais que se prolongam desde o Alto Rio Mississipi e seus tributários em Minesota, se estendendo por todo caminho até o Golfo do México. A Bacia do Rio Mississipi inclui quase $10.000 \mathrm{~km}$ de rios navegáveis, incluindo os rios Mississipi, Minesota, Missouri, Illinois, Ohio, Arkansas, Tennessee, White River, Cumberland e Alabama. Estima-se que $70 \%$ dos produtores de soja tenham acesso a uma hidrovia (US CORPS OF ENGINEERS, 2016). A Figura 12 ilustra as eclusas e represas das bacias do rio Mississipi e do rio Illinois. Os pontos de origem estão marcados em vermelho e os pontos de destino em azul. 


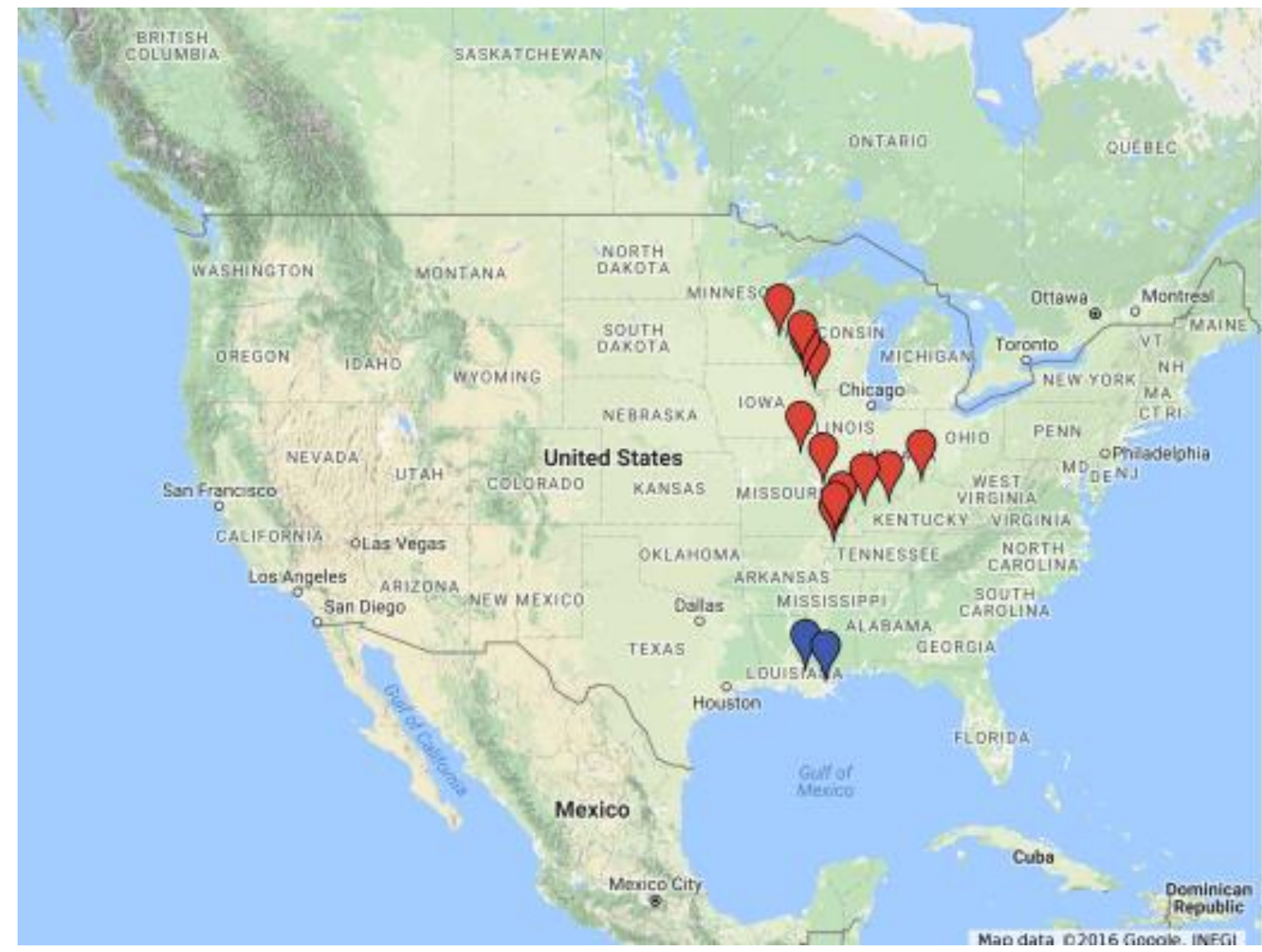

Figura 12 - Principais barragens e eclusas consideradas pelo presente estudo.

Fonte: Elaborada pela autora com website Google Company (2016).

A frota de barcaças norte-americanas contém cerca de 11.000 barcaças cobertas, para carregamento de cargas a granel como grãos, por exemplo. Há cerca de 2.000 barcos de reboque para empurrar as barcaças rio acima e rio abaixo. Um barco de reboque pode empurrar de 40 a 50 barcaças, cada uma delas transportando cerca de 1.500 toneladas de carga (US CORPS OF ENGINEERS, 2016). A Figura 13 foi retirada de um manual de navegação segura do Corpo de Engenheiros do Exército NorteAmericano. Ela ilustra uma composição de 15 barcaças cobertas, empurrada por um reboque no rio Mississipi. A frase Blind Spot significa Ponto Cego, isto é, o operador do reboque não enxerga o que está à frente. A frase Danger Zone significa Zona de Perigo, isto é, deve-se manter distância lateral ao se navegar perto de uma composição. E a frase Dager: Turbulent Water significa Perigo: Águas Turbulentas. As cinco barcaças alinhadas medem aproximadamente 370 metros. 


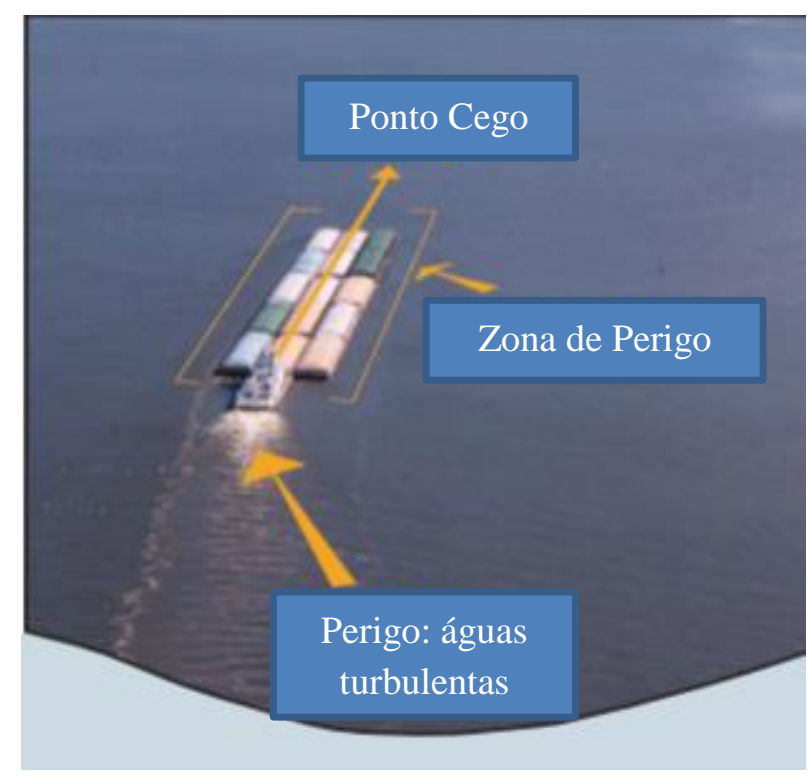

Figura 13 - Composição de barcaças no rio Mississipi. Fonte: US Corps of Engineers (2016).

Em toda hidrovia existem centenas de terminais elevadores que recebem soja de caminhões ou trens e a transferem para as barcaças. A maioria desses terminais não é usada para estocar soja por mais tempo do que a espera até a próxima barcaça. Normalmente, eles têm uma capacidade de armazenamento reduzida e sua função principal é transferência de carga (US CORPS OF ENGINEERS, 2016).

O Rio Mississipi passa por Baton Rouge (cidade com grande quantidade de beneficiadores de soja) e desemboca em Nova Orleans, no Golfo do México. Este é hoje o principal caminho para que a soja norte-americana atinja os mercados externos (US CORPS OF ENGINEERS, 2016).

O Golfo do México é dividido em três áreas: Golfo Leste, Golfo Central e Texas ou Golfo Oeste. O Golfo Leste se refere aos portos de Mobile, Alabama-Pascagoula e Mississipi. O Golfo Central está ligado ao Rio Mississipi, Nova Orleans e ao estado de Louisiana, enquanto o porto do Golfo Oeste é no Texas. A exportação de soja se dá predominantemente pelo Golfo Central. Apenas pequenos produtores locais de soja, que não têm outra opção viável, usam o Golfo Leste (US SOYBEAN EXPORT COUNCIL, 2013).

Há 12 elevadores de carga localizados ao longo do Rio Mississipi nas proximidades de Nova Orleans, todos de operação privada. Eles estão espalhados entre Myrtile Grove na Milha (61 milhas da cabeceira do rio) até Baton Rouge na Milha 229. Normalmente, há cerca de 10 metros de água doce no berço, permitindo que embarcações de 50.000 toneladas ou mais entrem para serem carregados. Certa 
quantidade dessas instalações pode carregar mais de 50.000 toneladas métricas por dia, algumas têm dois berços e podem carregar até dois navios por vez, descarregando as barcaças ao mesmo tempo (US SOYBEAN EXPORT COUNCIL, 2013).

O transporte fluvial está mudando, desde 2000, e a tendência é escoar gradativamente menos carga pelo Sistema do Alto Mississipi e do Rio Illinois. Essa tendência é particularmente evidente para o transporte de soja, com o aumento de carga embarcada pelo Sistema do Baixo Rio Ohio e Baixo Mississipi. Essa mudança aconteceu devido às plantações de milho para fabricação de etanol na região, o que requisitou o uso intensivo de barcaças (INFORMA ECONOMICS, 2012).

O transporte de alimentos e produtos agrícolas por meio do modal rodoviário compromete a capacidade das maiores rodovias interestaduais americanas. A interação com outros modais é especialmente importante pela relação de complementariedade e pela competição entre os modais, para manter a produção americana competitiva em mercados globais. Na cadeia logística do produtor rural até o consumidor final, os caminhões são responsáveis pelas primeiras e, em alguns casos, pelas últimas milhas.

Caminhões são amplamente utilizados para o transporte de produtos químicos, rações, fertilizantes, sementes e equipamentos e mais de $80 \%$ das cidades americanas são servidas exclusivamente pelo modal rodoviário (ESTADOS UNIDOS, 2010).

A disponibilidade de motoristas, especialmente durante os períodos de safra, é fator crítico para a lucratividade agrícola. Mais de $96 \%$ das transportadoras americanas são pequenas com menos de 20 caminhões, $87 \%$ têm menos de seis e quase $50 \%$ das empresas têm apenas um caminhão. A maioria dos motoristas para longos trajetos é paga por milha, por preço fechado ou por um percentual da venda da carga; os motoristas nunca são pagos por hora (SALIN, 2016).

Ao contrário da realidade brasileira, onde prevalecem as grandes transportadoras, o motorista, na maioria dos casos, é contratado como funcionário da empresa, com a regulamentação da quantidade máxima de horas de trabalho recentemente aprovada. O mercado temia que essas mudanças legislativas pudessem afetar o transporte de grãos. Entretanto, até o momento, nenhuma mudança significativa foi percebida pelos observadores internacionais (SALIN, 2016).

A condição americana é diferente da brasileira no que se refere à distância percorrida, tamanho das transportadoras, disponibilidade de motoristas e legislação trabalhista. No entanto, elas são próximas no que se refere ao tamanho e à capacidade de carga dos caminhões disponíveis. 
Admite-se que o leitor está mais familiarizado com a localização e logística dos estados brasileiros, portanto, foi possível fazer uma descrição sucinta deles, agregando por macrorregiões. Já no caso norte-americano, essa exposição precisa ser um pouco mais detalhada para o leitor não de outra nacionalidade. Optou-se por estruturar a partir de estados logisticamente mais relevantes, isto é, começando pelos estados com grandes entroncamentos ferroviários e hidroviários ligando diversos outros estados entre si.

Illinois (IL): O estado tem mais de $11.000 \mathrm{~km}$ de trilhos de trem. Dezoito terminais intermodais estão localizados em Illinois para transporte de soja em containers. Illinois faz parte do Programa de Proteção das Hidrovias do Departamento Norte-Americano e do Conservation Reserve Enhancement Program. Esses esforços para proteger a qualidade da água afetam aproximadamente 132.000 acres de plantações nas proximidades dos rios. $\mathrm{O}$ acesso de Illinois aos três maiores rios permite aos fazendeiros transportar sua colheita sem alto custo energético e forte impacto na poluição do ar (SOY ILLINOIS, 2012a). A Figura 14 ilustra a posição do estado de Illinois e a densidade de plantações por distrito. A cor verde escura identifica os distritos mais densamente ocupados por plantações.

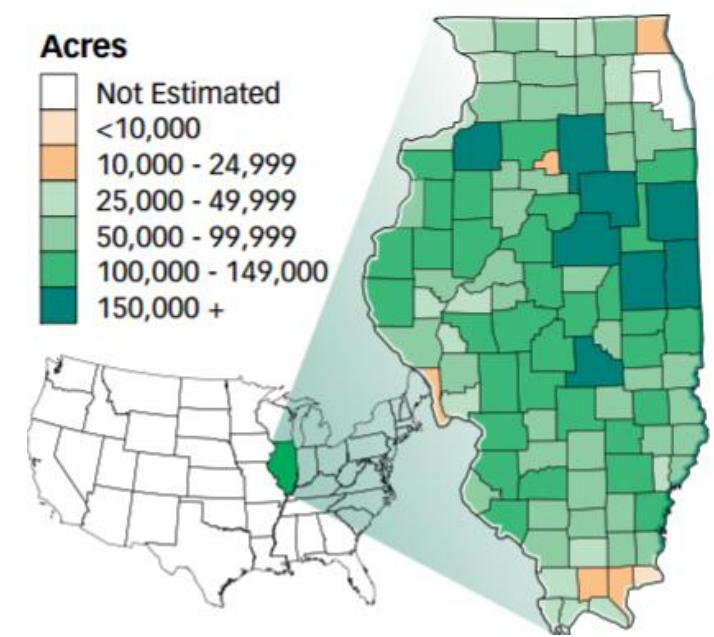

Figura 14 - Agricultura em Illinois. Fonte: Soy Illinois (2012a).

Desde 1988, o programa Sustainable Agriculture Research Education (SARE Pesquisa e Educação para Agricultura Sustentável, tradução livre) tem ajudado sistemas de agricultura avançados que são lucrativos e ambientalmente corretos para comunidades. Em 2011, o Keep for the Crop (KIC) for 2015 (Mantenha a Safra para 2015, tradução livre), programa de tratamento dos nutrientes, foi lançado para coordenar 
pesquisas focadas na redução da perda de nutrientes do solo e aumentar a eficiência nutricional (SOY ILLINOIS, 2012a).

Durante um período de 20 anos (1987-2007), o uso energético por bushel de soja colhida, medida equivalente a $27,22 \mathrm{~kg}$ de soja, diminuiu $65 \%$ e as emissões de $\mathrm{CO}_{2}$ por bushel aumentou 35\%. Em 2011, 92\% dos acres de soja plantados no Illinois foram plantados com soja tolerante a herbicidas, que se traduz em uso reduzido de produtos químicos e combustíveis (SOY ILLINOIS, 2012a).

Localizado numa posição central dos EUA, Illinois se beneficia do acesso a uma grande variedade de opções de transporte. As hidrovias do Illinois proporcionam transporte eficiente de soja para o Golfo do México para exportação para Ásia, América Latina e mercados europeus. Outras hidrovias podem transportar containers pelo Pacific Northwest e St. Lawrance Seaway. Illinois também oferece acesso para uma ampla rede de ferrovias (SOY ILLINOIS, 2012a). A Figura 15 apresenta dois mapas dos terminais intermodais de Illinois e uma foto de um desses terminais. À direita da Figura 15, observam-se as rodovias interestaduais (Interstates highways em inglês) marcadas em vermelho e as hidrovias em azul (Rivers em inglês). Ao centro da Figura 15, observamse as linhas férreas de Illinois (Railroad em inglês), listadas pelas empresas operadoras.
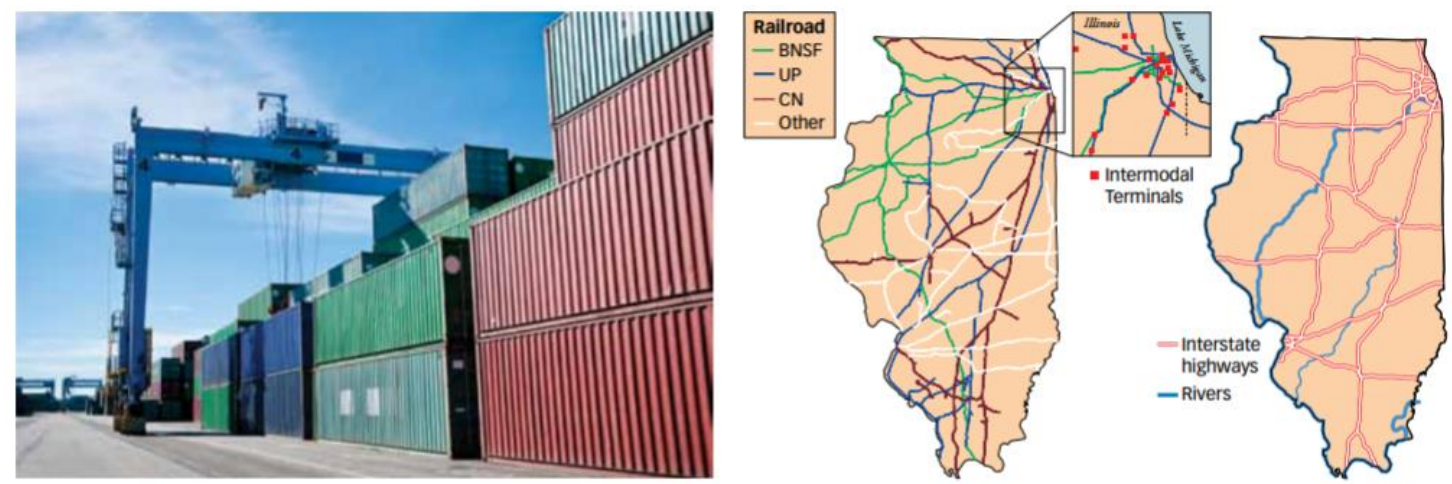

Figura 15 - Terminais intermodais de Illinois.

Fonte: Soy Illinois (2012a)

Illinois tem um posicionamento exclusivo como o maior corredor de transporte de carga norte-americano. Todos os principais modais de transporte conectam Illinois com o Meio Oeste, com o resto da nação e com o mundo. Chicago é o locus da maior rede ferroviária dos EUA, conectando o oeste com o leste. Illinois tem mais de 11.000 $\mathrm{km}$ de trilhos, mais de $1.700 \mathrm{~km}$ de rios navegáveis e 55 elevadores ao longo de cada rio, além de ser banhado pelo Lago Michigan que permite o transporte com containers para exportação direta. Illinois tem quase $60.000 \mathrm{~km}$ de rodovias e 22 terminais 
intermodais, conectando essas rodovias aos modais hidroviário e ferroviário (SOY ILLINOIS, 2012a). A Figura 16 ilustra os corredores de exportação que partem de Illinois, considerando todos os produtos exportados.

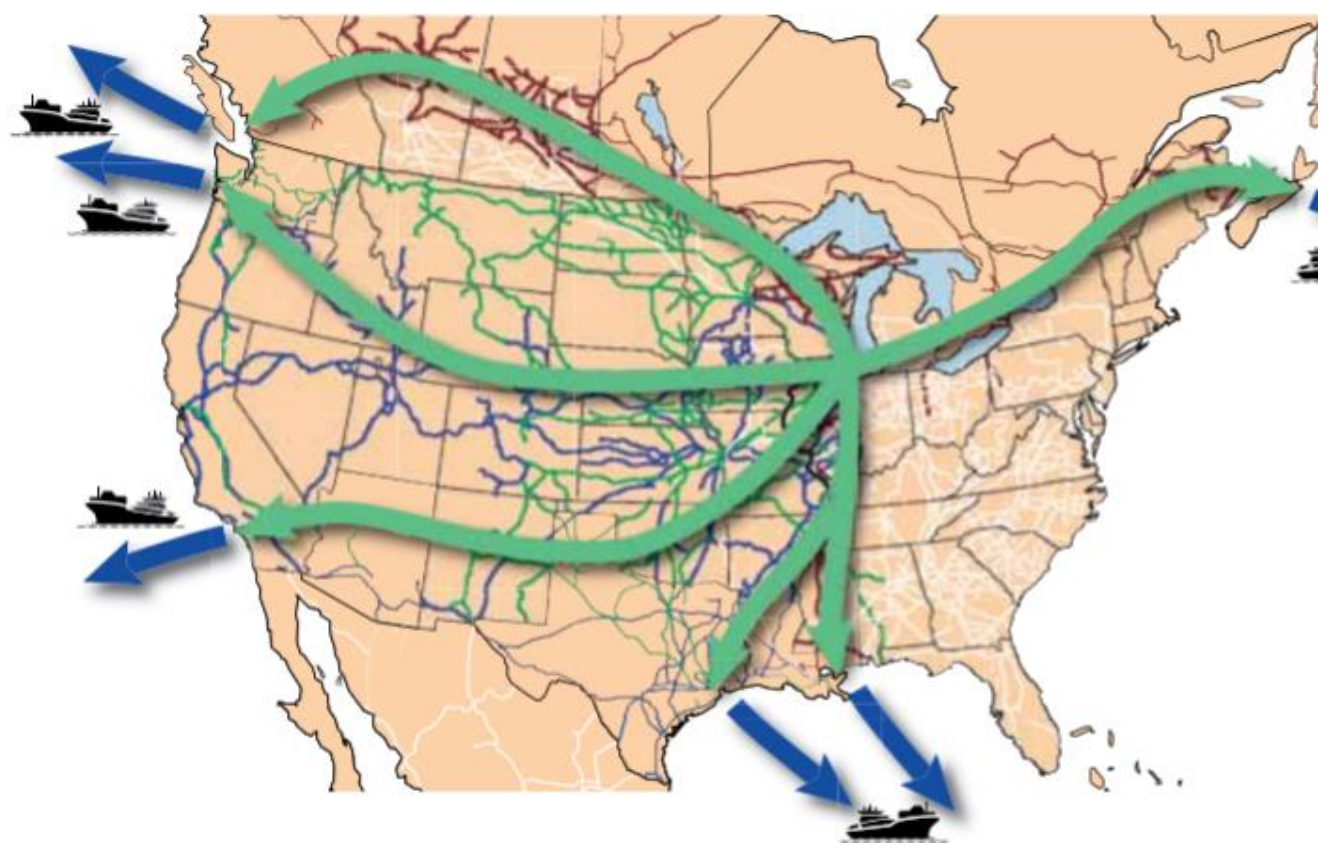

Figura 16 - Corredores de exportação que partem de Illinois.

Fonte: Soy Illinois (2012a).

As rotas hidroviárias que delimitam as fronteiras de Illinois são o Rio Mississipi ou o Rio Ohio, enquanto o Rio Illinois corta o estado diagonalmente de Chicago até Grafton. (US CORPS OF ENGINEERS, 2016).

Lembrando que, em português, uma barragem, açude ou represa, é uma barreira artificial, feita em cursos de água, como um rio, por exemplo, para a retenção de grandes quantidades de água. Em inglês, a palavra para represa é dam. Já uma eclusa é uma obra de engenharia hidráulica que permite que embarcações subam ou desçam os rios ou mares em locais onde há desníveis (barragem, quedas de água ou corredeiras). Em inglês, a palavra para eclusa é locks. Os rios Mississipi e Illinois apresentam declive acentuado, necessitando de diversas barragens e eclusas para que a navegação seja viável. Todas as eclusas e barragens norte-americanas possuem um código de identificação, normalmente este código é "L\&D" (Lock \& Dam), seguindo de um número (US CORPS OF ENGINEERS, 2016).

Há quinze eclusas na Bacia Superior do Mississipi, três no Rio Ohio, uma no Kaskaskia (rio integrante da bacia do Mississipi), sete no Illinois e duas localizadas em Chicago, próximas ao Lago Michigan. Três portos de calado profundo (Waukegan, 
Chicago e Camulet) garantem acesso aos mercados doméstico e internacional por meio dos Grandes Lagos e de Saint Lawrence e alto mar (WATERWAYS COUNCIL, 2016).

Entre os portos fluviais mais importantes destacam-se três:

- Chicago Harbor (IL): este porto se localiza na porção baixa de Chicago, delimitado pela rua Oak ao norte, Rush a oeste e Roosevelt ao sul. Essa localidade possui aproximadamente sete docas ou localizações de ancoragem (WATERWAYS COUNCIL, 2016);

- Chicago (IL): a localização deste porto é definida pelas docas e zonas de ancoragem no Chicago Area Waterway, Lago Calumet e Porto e Rio Calumet. A Chicago Area Waterway inclui: Chicago Harbour, Rio Chicago (braços principal, sul e direito), Chicago Sanitary e Canal de Chicago, Canal Calumet-Sag e Lago Calumet A localidade possui cerca de 188 docas, 1 ancoragem e 4 áreas de ancoragem (ibid.);

- Saint Louis (IL e MO): a localização deste porto se estica de $92 \mathrm{~km}$ ao sul de Saint Louis até aproximadamente $22 \mathrm{~km}$ ao norte da cidade. Essa localidade tem aproximadamente 155 docas e 13 áreas de ancoragem (ibid.).

Os dois últimos portos manipulam e transportam anualmente uma quantidade de carga equivalente, enquanto Chicago Harbour é significativamente inferior na mesma atividade (WATERWAYS COUNCIL, 2016).

Além de portos, existem diversas represas e eclusas que podem ser usadas para o carregamento e o descarregamento de carga de soja. Vinte oito eclusas e represas operam ao longo dos canais fluviais no estado de Illinois. Três eclusas estão localizadas ao longo dos 209 km do Rio Ohio, oito estão localizadas na hidrovia do Illinois, quinze no Rio Mississipi e as demais estão localizadas na confluência entre o Rio Chicago e o Lago Michigan e na confluência entre o Rio Kaskaskia e o Mississipi (WATERWAYS COUNCIL, 2016).

O movimento de mercadorias a montante e a jusante no Rio Mississipi é balanceado na parte alta do rio (da L\&D 12 até 15). A carga a jusante tende a ser relativamente estável da L\&D 12 até 24 . A tonelagem na direção à jusante tende a chegar ao dobro da tonelagem na direção à montante quanto mais se aproxima da confluência entre os rios Ohio e Mississipi. A tendência de aumento da carga à jusante é acentuada, no Rio Mississipi, entre as cidades de Quincy e Cairo (ibid.). A Figura 17 
ilustra os terminais contemplados por este estudo. Em vermelho, estão as regiões produtoras, em azul, os principais portos, e, em verde, principais L\&Ds.

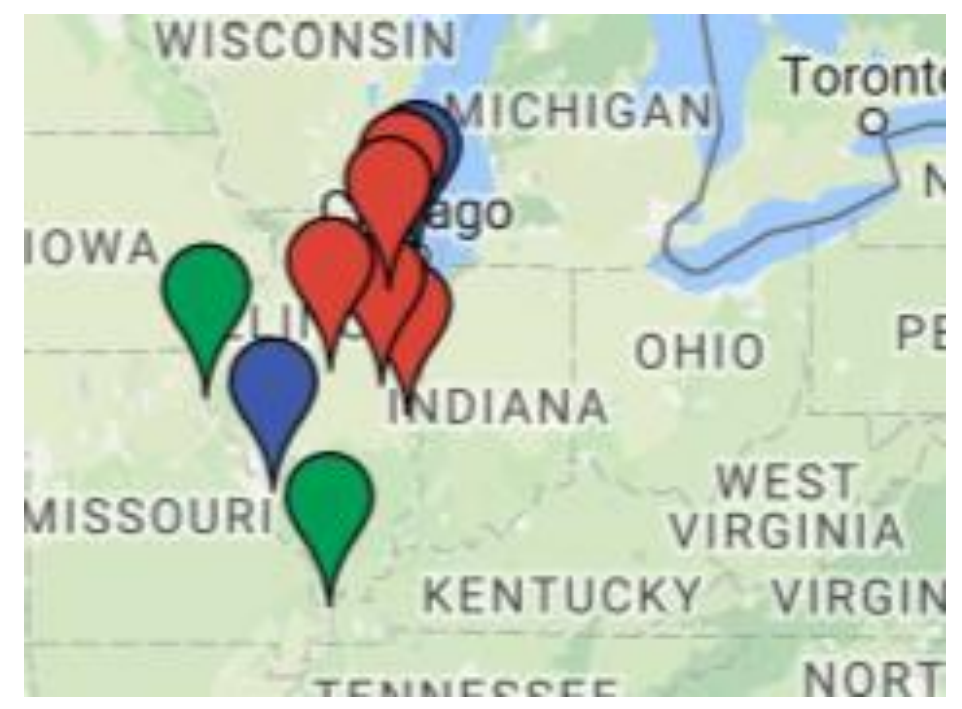

Figura 17 - Terminais analisados em Illinois.

Fonte: Elaborada pela autora com website Google Company (2016).

Iowa (IA): O coração do sistema ferroviário norte-americano parte de Illinois, como mostrado na Figura 11, os demais estados são entendidos como usuários da infraestrutura das empresas BNSF e UP.

Já o sistema hidroviário fluvial possui particularidades estaduais. As fronteiras do estado de Iowa são estabelecidas pelo Rio Missouri (a oeste) e pelo Rio Mississipi (a leste), mas o segundo é a única rota navegável que transporta uma quantidade de carga considerável (cerca de 7,8 milhões de tonelada por ano) (WATERWAYS COUNCIL, 2016). A Figura 18 ilustra a localização de Iowa (em amarelo), nota-se que Iowa faz fronteira com Illinois (verde escuro à direita).

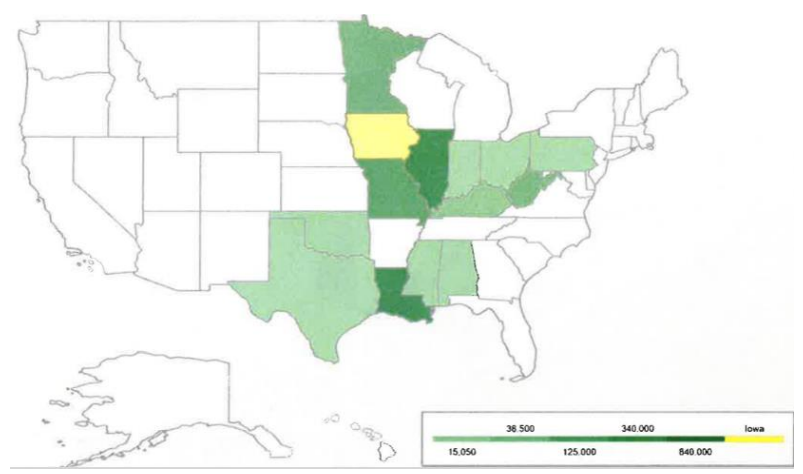

Figura 18 - Localização do Estado de Iowa em amarelo. Os Estados em verde estão sob responsabilidade do Corpo de Engenheiros do Exército.

Fonte: US Corps of Engineers (2016). 
Os principais portos de Iowa não são necessariamente um único ponto numa localização específica, mas, sim, geralmente um aglomerado de docas dentro de um único município (ou coleção de municipalidades) reconhecido por um estado (ou estados) com o propósito de ser designado como um porto. A mesma lógica de denominação se aplica todos os portos importantes listados na descrição dos demais estados (WATERWAYS COUNCIL, 2016). Entre os portos fluviais mais importantes destacam-se dois:

- Dubuque Comercial Harbor (IA): o Port of Dubuque and Commercial Harbour está localizado em Dubuque, Iowa, na região onde Iowa, Wisconsin, Illinois encontram as bacias do rio Mississippi (WATERWAYS COUNCIL, 2016);

- Prairie du Chien (WI): As instalações do Prairie Du Chien incluem os operadores de areia e cascalho. Destaca-se pela especialização em receber fertilizantes, argilas e sais. A porção do porto Prairie du Chien, que fica no Wisconsin, movimenta cerca de 217.300 toneladas destinadas e/ou originadas em Iowa (ibid.).

Além de portos, existem diversas represas e eclusas que podem ser usadas para carregamento e descarregamento de carga de soja. Todas as 11 eclusas e barragens no estado de Iowa estão localizadas no rio Mississippi. Lembrando que, as eclusas e represas são designadas pelo código "L\&D", seguido de um número. Em Iowa, estão localizadas as eclusas e represas de L\&D 9 a 18. A numeração mais baixa das represas e eclusas começa no norte do estado e a numeração vai aumentando, de modo incremental, na direção à jusante (WATERWAYS COUNCIL, 2016).

A tonelagem nas barragens superiores tende a ser balanceada para ambos os sentidos, i.e., as cargas têm pesos próximos tanto subindo quanto descendo o rio. Nas barragens inferiores, a tonelagem tende a ser desbalanceada, com maior quantidade de carga descendo o rio. Essa carga é predominantemente de grãos, que são carregados em barcas para começar sua jornada no sudoeste por meio de numerosas docas ao longo do Rio Mississipi. Os carregamentos na direção à jusante são majoritariamente de fertilizantes, destinados a Minesota, Iowa e Illinois (ibid.). A Figura 19 ilustra os principais distritos produtores de soja do estado em vermelho e os principais portos fluviais em azul. Lembrando que, também é possível escoar soja, por meio do modal ferroviário, para o Oceano Pacífico (Figura 16). 


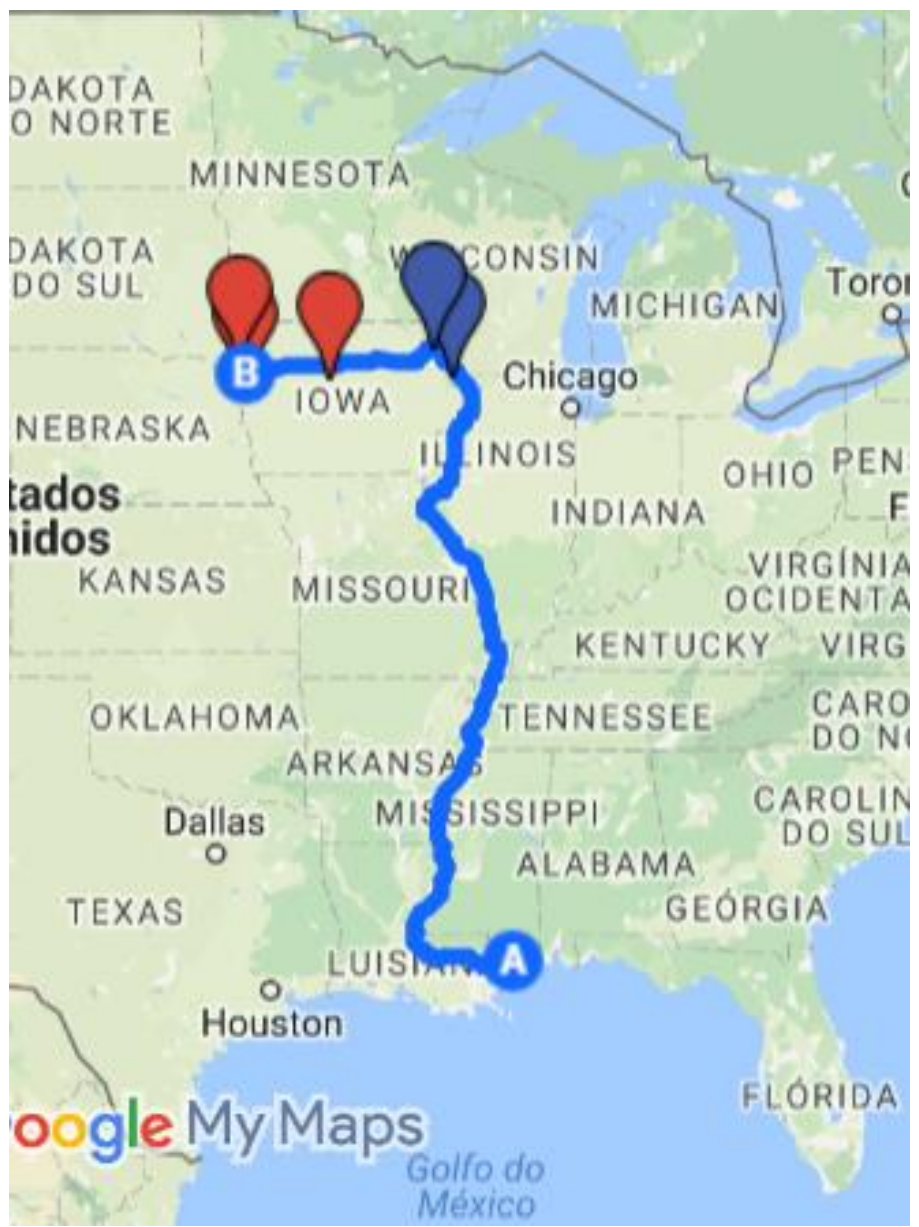

Figura 19 - Corredor de Iowa para o Golfo do Mississipi.

Fonte: Elaborada pela autora com website Google Company (2016).

Indiana (IN): Indiana faz fronteira ao norte com Michigan, ao oeste com Illinois, ao sul com Kentucky e ao leste com Ohio. O Rio Ohio proporciona acesso ao Rio Mississipi, Porto de Nova Orleans e Golfo do México. As docas de Indiana enviam produtos para 16 outros estados. Louisiana é o segundo estado com maior número de envios (WATERWAYS COUNCIL, 2016). A Figura 20 ilustra em azul a posição dos principais portos de Indiana, em vermelho, dos principais distritos fluviais e, em verde, das principais eclusas e barragens do Rio Ohio. 


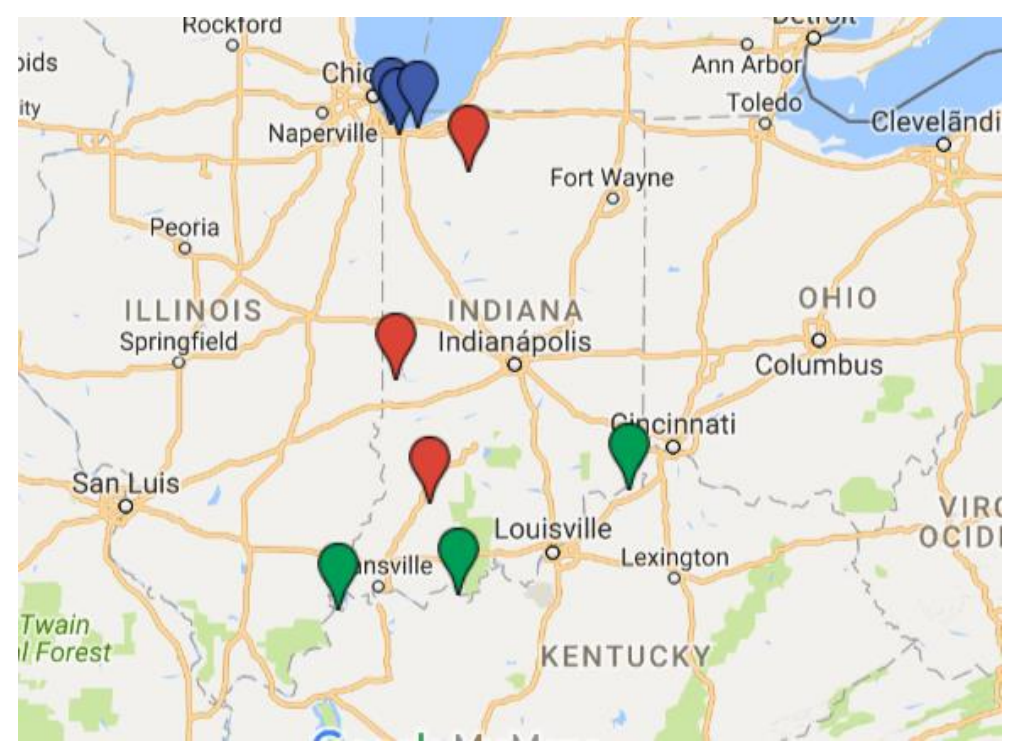

Figura 20 - Terminais analisados em Indiana.

Fonte: Elaborada pela autora com website Google Company (2016).

Os principais portos fluviais de Indiana (Indiana Harbour, Gary e Burns Waterway Harbour) são dedicados quase exclusivamente ao transporte de minérios, fugindo do escopo deste trabalho (WATERWAYS COUNCIL, 2016).

Há cinco eclusas e represas na parte navegável do Rio Ohio, fronteira de Indiana. Ao contrário de outros estados, onde as eclusas são simplesmente numeradas, em Indiana elas têm nomes próprio. São: Markland L\&D, McAlpine L\&D, Cannelton L\&D, Newburg L\&D e John T. Myers L\&D, seguindo sentido à jusante (WATERWAYS COUNCIL, 2016).

Minesota ou Minnesota (MN): É o estado mais ao norte deste estudo. Minesota faz fronteira ao norte com o Canadá, a oeste com Dakota do Norte e com Dakota do Sul, ao sul com Iowa, a leste com Wisconsin e com o Lago Superior. Os dois maiores centros industriais e comerciais do estado (Twin Cities e Duluth) são servidos pela hidrovia do Minesota. Duluth é servido pelo Lago Superior e Saint Paul é servida pelos sistemas de navegação dos Rios Alto Mississipi, Minesota e St. Croix. Os portos mais importantes são Two Harbors, Duluth-Superior e Silver Bay, mas eles são focados no transporte de minérios, fugindo do escopo deste trabalho (WATERWAYS COUNCIL, 2016). A Figura 21 ilustra em azul a posição dos principais portos de Minesota, em vermelho, dos principais distritos fluviais e, em verde, das principais eclusas e barragens do Alto Mississipi. 


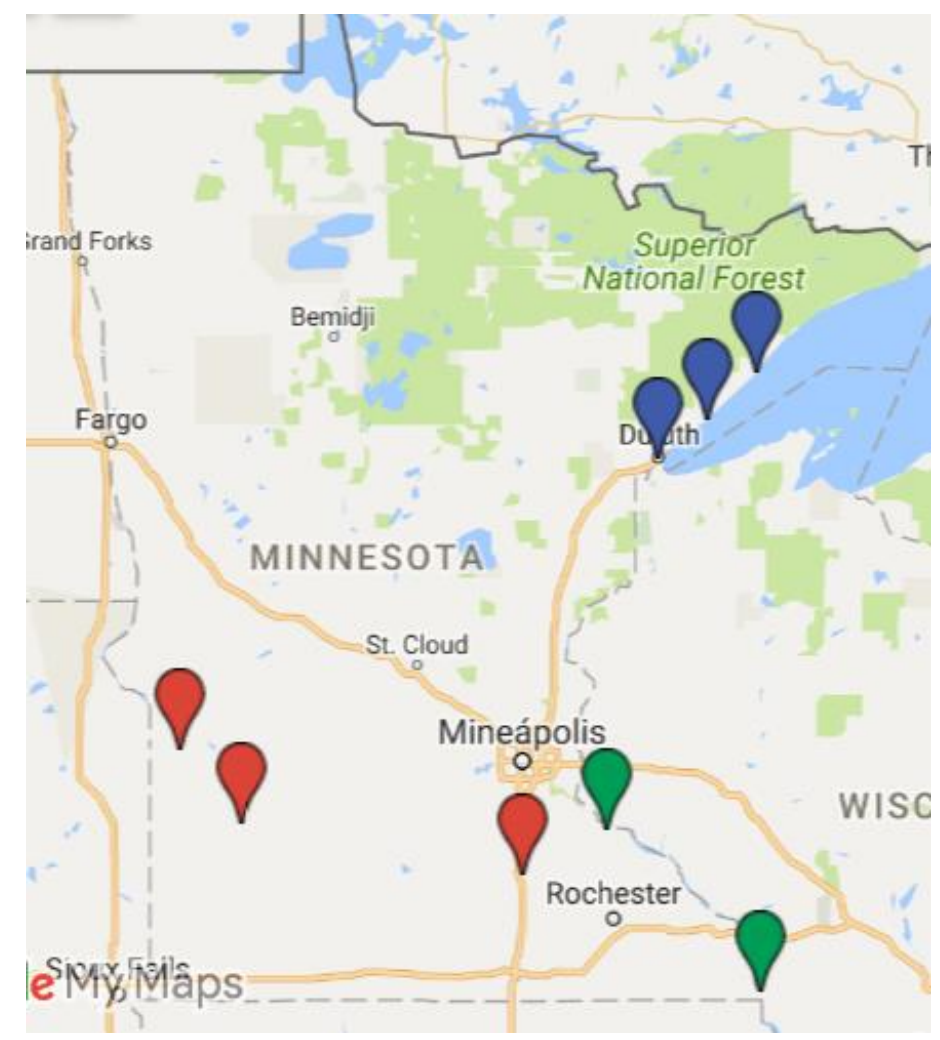

Figura 21 - Terminais analisados em Minesota.

Fonte: Elaborada pela autora com website Google Company (2016).

Todas as onze barragens e eclusas do estado estão localizadas no Alto Rio Mississipi. Sua distribuição começa nas eclusas e represas abaixo e acima das quedas de Saint Anthony em Minneapolis. As eclusas de cima das quedas erguem as barcaças por 15 metros, sendo a maior elevação de todo Rio Mississipi. A primeira eclusa e represa deste rio ( $L \& D$ 1) é em Minesota, próxima a cidade de Saint Paul, e a numeração continua aumentando rio abaixo, até a L\&D 8, próxima a Genoa, Wisconsin (WATERWAYS COUNCIL, 2016).

A maior parte do tráfego no Alto Rio Mississipi tem uma distribuição de carga igual nas duas direções (jusante e montante). O tráfego a jusante é predominantemente de grãos destinados à Louisiania. O tráfego à jusante aumenta significativamente a partir da L\&D 3, próxima à cidade de Red Wing e continua até a L\&D 8, na fronteira com estado de Wisconsin. Por isso, este trabalho considera rotas terrestres das principais cidades produtoras até essas duas eclusas e represas (WATERWAYS COUNCIL, 2016).

Embora menos de 6\% da produção estadual seja classificada pelo Waterborne Commerce Statistical como exportação, isso não é uma representação real dos fatos. Embora os grãos sejam reportados tendo como destino o mercado doméstico, a maioria 
dos grãos que entram em Louisiana é processada lá, carregada no Golfo do México e enviada o mercado internacional (ibid.).

Missouri (MO): se localiza no coração das rotas fluviais dos EUA. Missouri é um estado de localização central, ele faz fronteira, a leste, com Illinois. A infraestrutura e a localização permitiram ao estado a capacidade de mover tanto matéria-prima quanto produtos acabados de maneira rápida e econômica por trem, barcaça e caminhão. Os Rios Mississipi e Missouri proporcionam rotas importantes para o transporte de materiais com pouco valor agregado (WATERWAYS COUNCIL, 2016). A Figura 22 aponta, em vermelho, a localização das principais regiões produtoras do Missouri e os principais portos fluviais, em azul, que também se caracterizam por possuir eclusas e barragens (L\&D).

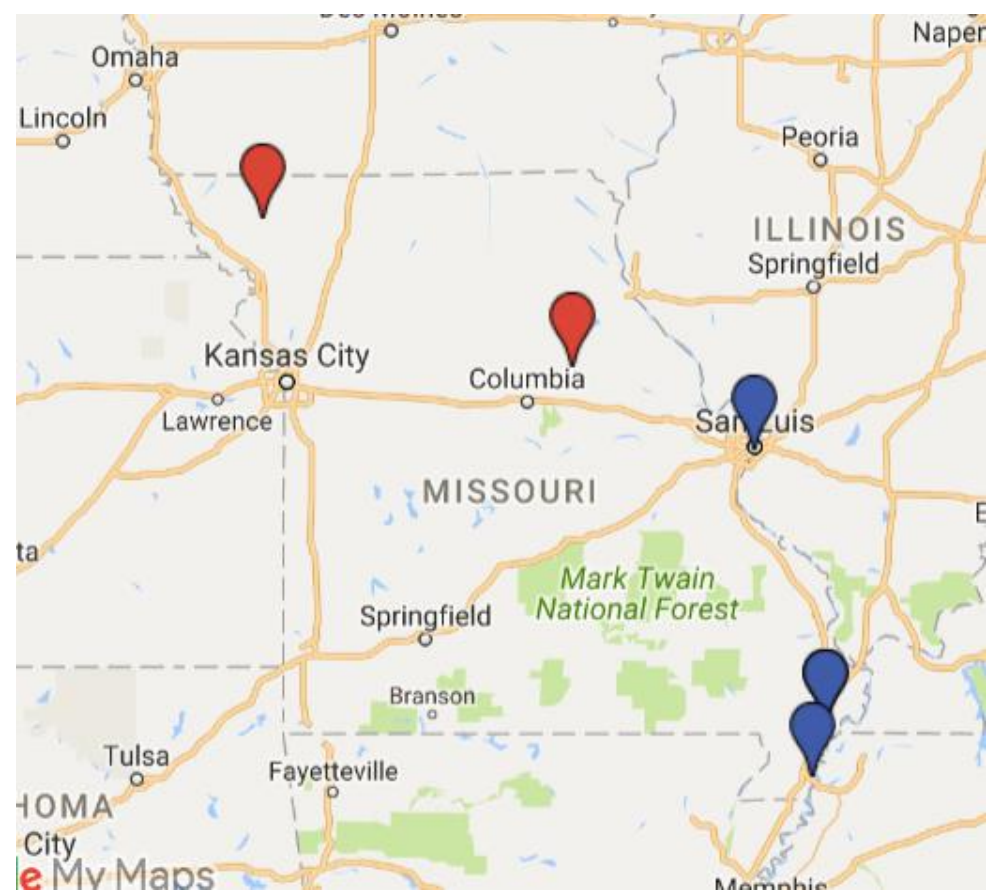

Figura 22 - Terminais analisados em Missouri.

Fonte: Elaborada pela autora com website Google Company (2016).

Os portos fluviais mais importantes são:

- St. Louis (MO): o porto de St. Louis é gerenciado pela St. Louis Authority. O porto opera $113 \mathrm{~km}$ nas duas margens do Rio Mississipi e possui 130 obras de infraestruturas. O Porto de St. Louis é o segundo maior porto fluvial americano; suas cargas são predominantemente minério de ferro e fertilizantes (WATERWAYS COUNCIL, 2016); 
- Caruthersville Harbor (MO): a Permiscot Count Port Authority oferece acesso ao transporte por barcas via sistema fluvial. Um porto de águas rasas está localizado a cerca de $1.400 \mathrm{~km}$ do Baixo Rio Mississipi. A autoridade portuária providencia acesso intermodal por meio de uma união estratégica com linhas ferroviárias (ibid.);

- New Madrid Harbor (MO): importante ressaltar que o porto é operado pela autoridade portuária estadual, sendo a carga predominantemente de fertilizantes e grãos (ibid.).

Há sete eclusas e barragens navegáveis no Missouri, todas ao longo do Rio Mississipi. A tonelagem tende a ser mais pesada nas docas à jusante, refletindo o movimento para a Louisiana de grãos produzidos em Illinois, Iowa, Wisconsin, Missouri e Minesota. Carregamentos com minério de ferro também se movem na direção à jusante. A carga a montante consiste primariamente de fertilizantes destinados a Minesota, Illinois, Missouri e Wisconsin (ibid.).

\subsection{Análise Envoltória de Dados (DEA): Conceitos Fundamentais}

A Data Envelopment Analysis (DEA) é uma técnica baseada em programação linear, que mensura a eficiência relativa de unidades organizacionais quando há presença de múltiplas variáveis de entrada (inputs) e de saída (outputs). Essa condição complexa pode tornar a avaliação difícil ou irrealizável por outros métodos. O principal resultado obtido com a aplicação da DEA é o escore (ranking) de eficiência relativa das unidades (CHARNES, COOPER e RHODES, 1978).

Lembrando que eficiência é um conceito relativo que compara o que foi produzido por unidade de insumo utilizado com o que poderia ser produzido. Ou seja, a forma com que os recursos são utilizados está relacionada com a tecnologia adotada e com o respectivo processo de produção. Existem diferentes formas de se medir a eficiência produtiva. Entre eles, que podem ser paramétricos (estatísticos) e os nãoparamétricos. Os primeiros supõem uma relação funcional entre a produção e os insumos e utilizam como suporte medidas de tendência central, por exemplo, a média aritmética. A DEA, sendo um método não-paramétrico, não faz suposições sobre a relação funcional entre insumos e produtos. Ela define os valores relativos que podem ser produzidos com base na observação e comparação de dados das organizações ou atividades do conjunto analisado, destacando as eficiências relativas de cada 
organização e identificando as organizações mais eficientes (FERREIRA; GOMES, 2012).

Uma Decision Making Unit (DMU), Unidade para a Tomada de Decisão, tradução livre) é o termo técnico usado para cada uma das unidades comparadas em um num modelo DEA. No presente estudo, trata-se de cada rota de transporte de carga. $\mathrm{O}$ escore de eficiência relativa de uma DMU representa a máxima proporção de seus inputs que deve ser usada para garantir, pelo menos, o atual nível de outputs. Alternativamente, o inverso da eficiência é o valor mínimo por meio do qual os níveis atuais de output da rota podem ser multiplicados enquanto os níveis atuais de inputs se mantêm os mesmos. Portanto, DEA não apenas leva à identificação das rotas mais e menos eficientes, mas também mensura a conservação de recursos (inputs) e/ou o possível aumento dos outputs (BOUSSOFIANE; DYSON; THANASSOULIS, 1991).

\subsubsection{Considerações sobre a DEA: discutindo homogeneidade e empate}

A DEA parte do pressuposto que diferenças de desempenho dessas unidades "similares" existem e são mensuráveis. Porém, até mesmo em condições muito parecidas, podem-se encontrar diferenças entre as unidades estudadas, simplesmente pelo fato de que elas são gerenciadas por diferentes tomadores de decisão. Então, se por um lado a DEA busca um conjunto de unidades "homogêneas", onde a comparação faz sentido, por outro, a DEA é uma ferramenta desenvolvida para apontar diferenças entre DMUs. Golany e Roll (1989) desenvolveram um guia inicial para escolha de variáveis e DMUs. Os autores apontam três características para que um grupo de DMUs seja considerado homogêneo:

-as unidades consideradas desempenham as mesmas funções, com objetivos similares;

-todas as unidades atuam sob as mesmas "condições de mercados" (isso é especialmente relevante na análise de organizações não lucrativas como escolas, unidades militares, hospitais públicos, cortes judiciárias etc.);

-as variáveis (tanto inputs como outputs), que caracterizam o desempenho de todas as unidades do grupo, são idênticas, exceto por diferenças de intensidade e de magnitude.

Hua e He (2006) fizeram uma busca na literatura sobre DEA aplicado em conjunto de DMUs não homogêneas. Os autores identificam duas causas para não 
homogeneidade das DMUs: fatores ambientais e fatores tecnológicos. Quando os fatores são ambientas, costuma-se tomá-los como variáveis de entrada nãodiscricionárias e discriminar DMUs em ambientes diferentes definindo distintos conjuntos de referência. Já quando as causas são fatores tecnológicos, é raro achar diretrizes sobre como a análise DEA deve ser realizada. É difícil até mesmo achar uma definição de homogeneidade tecnológica na literatura corrente (ibid.).

Hua e He (2006) sugerem que DMUs são homogêneas para tecnologia quando atendem as três seguintes condições:

- Exercem atividades similares;

- Utilizam um grupo similar de recursos;

- Usam tecnologias comuns, i.e., um aumento em um input de cada DMU acarretará um aumento similar em output.

As duas primeiras condições podem ser facilmente verificadas por meio da observação direta dos dados ou da aplicação de uma análise de cluster, como, por exemplo, a Tiered DEA (BARR; DURCHHOLZ; SEIFORD, 2000). Para verificar a terceira condição de tecnologia homogênea, Hua e He (2006) propõem um método para julgamento da homogeneidade por meio do teste estatístico de hipótese, mais especificamente, por meio do teste não paramétrico de Wilcoxon. Não foi encontrada nenhuma aplicação de cross-match test (ROSENBAUM, 2005) para homogeneidade em DEA.

Lembrando que homogeneidade também é um conceito estatístico, que descreve a relação (linear ou não) entre elementos de uma distribuição (ROSENBAUM, 2005). O desafio de análises estatísticas de homogeneidade é determinar em que medida as características podem ser diferentes e, ainda assim, definir unidades do mesmo tipo. Heiser e Meulman (1992) expõem duas ferramentas paramétricas, a análise de componentes principais (PCA, do inglês, Principal Component Analysis) e o a (alfa) de Cronbrach, como ferramentas para se analisar homogeneidade. Os autores discutem que o PCA é um método de análise e da homogeneidade, mostrando uma conexão entre a perda de homogeneidade com a média quadrada da correlação de todas as variáveis, e com a matriz de correlação dos autovetores (eingenvalues). Heiser e Meulman (1992) também mostram que existe uma conexão entre o $\alpha$ de Cronbrach, a medida padrão de consistência interna que é igual à média de todos os possíveis coeficientes de $50 \%$ de confiabilidade. 
Além disso, na DEA, uma proporção relativamente grande de DMUs podem receber uma pontuação de eficiência máxima $(1,00)$, i. e., empatarem no topo do ranking (COOK; KRESS; SEIFORD, 1992). Não foi encontrado na literatura uma explicação sistematizada das causas de empate. Analisando-se a questão, é possível induzir três possíveis cenários de empate:

- se as DMUs forem muito homogêneas, é rara a não ocorrência de empates;

- se as DMUs forem muito heterogêneas, os empates tendem a ocorrer, principalmente, se o total de DMUs for pequeno. No limite de heterogeneidade (num modelo teórico onde número de DMUs é igual ao número de variáveis), cada DMU pode ser um benchmark (referencial de eficiência) na sua área (i.e., para uma variável). Nesse limite teórico, todas as DMUs seriam usadas para traçar a fronteira de eficiência e estariam empatadas (para evitar essa situação, existem regras práticas sobre a relação entre o total de variáveis e o total de DMUs a serem discutidas no subtópico 2.3.2);

- se dois conjuntos homogêneos de DMUs, mas heterogêneos entre si, forem comparados usando DEA, e, se um grupo for muito superior ao outro (em relação ao maior número de variáveis), esse grupo superior deveria ser responsável pelo maior número de empates. Esse é um cenário de possível ocorrência ao se comparar dois países, caso um deles seja superior ao outro em todos os aspectos.

Se o usuário deseja diminuir o número ou a proporção de DMUs eficientes vários modelos podem ajudar; como por exemplo, a restrição de pesos pode ser útil nesses casos (COOK; TONE; ZHU, 2016). Cook, Kress e Seiford (1992) apontam o problema de empate e sugerem técnicas subjetivas de desempate. Posteriormente, foram desenvolvidas técnicas objetivas de desempate, entre elas estão as técnicas que envolvem a construção de índices, como o índice composto (LETA et al., 2005) e o índice triplo (MARIANO; REBELATTO, 2014). Essas ferramentas parecem, inicialmente, adequadas ao uso para rotas de exportação, uma vez que, como discutido anteriormente, elas solucionam eventuais empates causados pela atribuição pesos da DEA. E a DEA, como método para comparação da eficiência de rotas, aparenta solucionar a questão da atribuição subjetiva de pesos encontrada por Panagakos (2016). 
A técnica do índice triplo tem se mostrado mais adequada para apontar outliers, i.e., DMUs que se destacam em todos os aspectos das demais (MELO et al., 2016). A técnica do índice composto (MARIANO; REBELATTO, 2014; LETA et al., 2005) está demonstrada na Equação 1:

$$
\mathrm{E}_{\mathrm{k}}^{\text {composto }}=\frac{\left[\mathrm{E}_{\mathrm{k}}^{\text {padrão }}+\left(1-\mathrm{E}_{\mathrm{k}}^{\text {invertida }}\right)\right] / 2}{\max \left\{\left[\mathrm{E}_{\mathrm{k}}^{\text {padra o }}+\left(1-\mathrm{E}_{\mathrm{k}}^{\text {invetidd }}\right)\right] / 2\right\}} \quad \mathrm{k}=1,2, \ldots, \mathrm{z}
$$

Equação 1 - Índice Composto.

Onde:

$\mathrm{E}_{\mathrm{k}}^{\text {composto }}$ : índice composto da k-ésima DMU.

$\mathrm{E}_{\mathrm{k}}^{\text {padrão }}$ : eficiência padrão da k-ésima DMU.

$\mathrm{E}_{\mathrm{k}}^{\text {invertida }}$ : eficiência invertida da k-ésima DMU.

z: número de DMUs.

Neste trabalho, a eficiência padrão, $\mathrm{E}_{\mathrm{k}}^{\text {padrão }}$, é a eficiência de $\tau^{*}$ (demonstração matemática no subtópico 2.3.3), calculada pelo modelo SBM. A eficiência invertida, $\mathrm{E}_{\mathrm{k}}^{\text {invertida }}$, é calculada invertendo-se inputs e outputs, i.e., inserindo os inputs como outputs (e vice-versa) no modelo SBM.

\subsubsection{Considerações sobre a escolha de variáveis}

Em qualquer estudo de eficiência organizacional é preciso ter visão global do processo. Uma clara especificação das funções exercidas em cada etapa vai direcionar a escolha dos inputs e outputs a serem estudadas. Enquanto os conceitos de variáveis de entrada e saída são bem definidas, pouca atenção tende a ser dada para a escolha das variáveis em si. Pode ser o caso de que, assim como a análise por regressão, ninguém pode estar completamente certo de que todas as variáveis relevantes foram incluídas, todos os esforços devem ser direcionados para incluir aquelas com mais impacto nas características práticas analisadas (COOK; TONE; ZHU, 2014).

Outra questão relevante na aplicação de DEA é o tamanho do grupo de DMUs analisado em comparação com o número total de variáveis (inputs e outputs) aplicado no modelo. Novamente, duas tendências são conflitantes. Por um lado, quanto maior o número de DMUs, maior será a probabilidade de empates. Por outro, há a tendência de 
aumentar o número de DMUs, porque quanto maior a população, maior a probabilidade de se capturar as unidades de alto desempenho que vão definir a fronteira de eficiência. Uma grande quantidade de unidades também permite uma identificação mais precisa das relações típicas entre inputs e outputs (COOK; TONE; ZHU, 2014).

Além disso, quando o número de DMUs aumenta, é possível incorporar mais variáveis à análise. É conhecido o fato de que um número grande de inputs e outputs (em relação ao número total de DMUs) restringe o poder discriminatório da DEA, aumentando o número de empates eficientes, conforme apontado por Cook, Tone e Zhu (2014). Golany e Roll (1989) apontam um princípio básico de adotar sempre duas vezes mais DMUs do que total de variáveis. Banker et al. (1989), por outro lado, recomendam que o total de DMUs seja três vezes maior que número de variáveis.

Para aumentar o poder discriminatório da DEA, que frequentemente falha quando há um número excessivo de outputs e inputs, em relação ao número de DMUs foi desenvolvida a análise combinada PCA-DEA dos dados. O PCA usado nesses casos é baseado na correlação, ao invés da covariância, uma vez que, as variáveis na DEA são, muitas vezes, quantificadas em diferentes unidades de medida. A PCA-DEA foi desenvolvido independentemente por Ueda e Hoshai (1997) e Adler e Golany (2001). Adler e Yazhemsky (2010) compararam PCA-DEA com o método de redução das variáveis baseada na covariância parcial e verificaram que PCA-DEA é uma ferramenta mais apurada e com resultados consistentemente mais acurados.

Dyson et al. (2001) discute algumas armadilhas da DEA. Uma delas é que o ranking de eficiência pode ser equivocado, quando inputs e outputs são simultaneamente porcentagens e/ou taxas (por exemplo, renda por empregado e retorno do investimento) e dados brutos (por exemplo, lucro, faturamento, número de empregados). Este fato foi levado em consideração para escolha de variáveis e coleta de dados.

\subsubsection{Considerações sobre a escolha do modelo DEA}

Existem diversos modelos DEA, de modo geral, eles divergem quanto ao retorno de escala, ao tipo de projeção e à orientação. O retorno de escala pode ser constante ou variável, sendo que o retorno constante pressupõe que uma variação nos inputs resultará em uma variação proporcional nos outputs. A projeção pode ser radial ou não radial, 
sendo que a primeira pressupõe que tanto inputs quanto outputs se aproximam da fronteira de eficiência de maneira equiproporcional. No que diz respeito à orientação, pode ser para maximização dos outputs, para minimização dos inputs ou para ambas simultaneamente, como é o caso do modelo aditivo. Alguns modelos são sensíveis a unidade de medida das variáveis (CAMIOTO, MARIANO e REBELATTO, 2014).

Uma característica dos modelos de DEA é a escolha dos pesos atribuídos aos insumos e respectivos produtos, baseados nos próprios dados do conjunto de DMUs em análise. A DEA aplica automaticamente os pesos que são mais favoráveis às DMUs e desconsideram alguns pesos que são mais favoráveis apenas às outras DMUs, atribuindo-lhes o valor zero. Por conseguinte, o valor zero de um peso mostra um ponto fraco da DMU com relação às variáveis de entrada e saída que ela pondera. É possível que especialistas em um dado segmento socioeconômico em análise, por meio de um modelo DEA, considere indevidas as proporções entre pesos que o modelo atribui aos insumos e produtos, e proponha modificá-las (FERREIRA; GOMES, 2012).

Entre esses modelos, o SBM foi criado por Tone (2001) e tem por como características a utilização das folgas do modelo aditivo para geração de um índice de eficiência e é invariante à unidade de medida, ou seja, podem-se utilizar tanto variáveis adimensionais tanto quanto variáveis com diferentes unidades (tempo, espaço, massa) sem que isso afete os resultados. A eficiência apresentada por este modelo é um valor entre 0 e 1, representando a redução média dos inputs e o aumento médio dos outputs necessários para se chegar à fronteira de eficiência.

Esta dissertação selecionou o modelo SBM porque possibilita a minimização dos inputs e maximização dos outputs simultaneamente; possui escala variável; é invariante à unidade de medida; e resulta diretamente num ranking de eficiência. Numa análise de rotas, transportar o máximo com o mínimo de recursos é o almejado. Nesse contexto, modelo SBM se destaca pela maior adequação ao objetivo almejado.

Além disso, DEA também pode ser aplicado para a construção de índices. Entre esses índices, que são utilizados para monitorar rotas de transporte no tempo (possivelmente tornando-se um API), destaca-se o Índice de Malmquist (FÄRE; GROSSKOPF; LOVELL, 1994). Esse índice mede a mudança de produtividade de uma DMU, sua interpretação é dada da seguinte maneira: quando o índice for maior que 1, houve evolução na produtividade; quando menor, não houve evolução entre um período e outro. E ele pode ser decomposto para mostrar se as variações de produtividade se 
devem às alterações de eficiência relativa ou às alterações tecnológicas (FÄRE; GROSSKOPF e LOVELL, 1994).

\subsubsection{Modelo Slack-Based Measure (SBM) e sua demonstração matemática}

Em prol do maior entendimento do leitor sobre como funciona o modelo DEA baseado em folgas Slack Basead Measeure (SBM), segue uma demonstração resumida, baseada no artigo de Tone (2001). Lidando com $n$ DMU's com matrizes, respectivamente, de inputs e outputs, $X=\left(x_{i j}\right) \in \mathbb{R}^{m x n}$ e $Y=\left(y_{i j}\right) \in \mathbb{R}^{s x n}$. Assumese que os dados são positivos, i.e., $X>0$ e $Y>0$. A função produção é definida como:

$$
P=\{(x, y) \mid x \geq X \lambda, y \leq Y \lambda, \lambda \geq 0\}
$$

Onde $\lambda$ é um vetor não negativo em $\mathbb{R}^{n}$. É possível impor algumas restrições em $\lambda$, tais como $\sum_{j=1}^{n} \lambda_{j}=1$ (como no modelo $\mathrm{BBC}$ ), se for necessário modificar o conjunto de produção. Considerando uma expressão para descrever uma certa DMU $\left(x_{0}, y_{0}\right)$ como:

$$
\begin{aligned}
& x_{0}=X \lambda+s^{-}, \\
& y_{0}=Y \lambda+s^{+},
\end{aligned}
$$

Com $\lambda \geq 0, \quad s^{-} \geq 0$ e $s^{+} \geq 0$. O vetor $s^{-} \in \mathbb{R}^{m}$ e $s^{+} \in \mathbb{R}^{s}$ indica, respectivamente, o excesso de inputs e a falta de outputs dessa expressão, isto é, as folgas (SBM, em inglês, significa mensuração baseada em folgas). A partir da condição, $\lambda \geq 0$ e $X>0$, chega-se a:

$$
x_{0} \geq s^{-} \text {. }
$$

Usando $s^{-}$e $s^{+}$, pode-se definir o índice $\rho$, para eficiência, assim:

$$
\rho=\frac{1-(1 / m) \sum_{i=1}^{m} s_{i}^{-} / x_{i 0}}{1-(1 / s) \sum_{r=1}^{s} s_{r}^{+} / y_{r 0}}
$$

Pode-se observar que $\rho$ atende duas das quatro propriedades mais importantes para realizar mensurações de eficiência: (1) as medições devem ser invariantes com relação as unidades de medida; (2) as medições devem decrescer de maneira monótona para toda folga de inputs e outputs. A partir da quarta propriedade (a medição deve ser 
determinada apenas consultando o conjunto referência de onde a DMU é originária), resulta que:

$$
0<\rho \leq 1
$$

No esforço de estimar a eficiência de $\left(x_{0}, y_{0}\right)$, Tone (2001) formula o seguinte programa fracionário em $\lambda, s^{-}$e $s^{+}$:

$(\mathrm{SBM})$

$$
\begin{gathered}
\text { Minimizar } \rho=\frac{1-(1 / m) \sum_{i=1}^{m} s_{i}^{-} / x_{i 0}}{1-(1 / s) \sum_{r=1}^{s} s_{r}^{+} / y_{r 0}} . \\
\text { Sujeito a } x_{0}=X \lambda+s^{-}, \\
y_{0}=Y \lambda+s^{+}, \\
\lambda \geq 0, s^{-} \geq 0, s^{+} \geq 0 .
\end{gathered}
$$

Para linearizar, Tone (2001) multiplica uma variável escalar positiva $t$ para tanto o numerador quanto o denominador de $\rho$. Isso não causa alterações em $\rho$. Ajusta-se $t$ para que o denominador se torne 1 . Assim, esse termo é movido para as restrições. $\mathrm{O}$ objetivo passa ser minimizar o numerador. Então, tem-se:

$$
\begin{gathered}
\text { Minimizar } \tau=t-(1 / m) \sum_{i=1}^{m} s_{i}^{-} / x_{i 0} \\
\text { Sujeito a } 1=t+(1 / s) \sum_{r=1}^{s} s_{r}^{+} / y_{r 0} \\
x_{0}=X \lambda+s^{-} \\
y_{0}=Y \lambda+s^{+} \\
\lambda \geq 0, s^{-} \geq 0, s^{+} \geq 0
\end{gathered}
$$

O problema dado acima é não linear uma vez que contém termos não lineares $t s_{r}^{+}(r=1, \ldots, s)$. No entanto, pode-se transformá-lo num problema linear definindo que:

$$
S^{-}=t s^{-}, S^{+}=t s^{+} \text {e } \Lambda=t \lambda
$$

Assim, a programação linear se torna a seguinte:

$$
\operatorname{Minimizar} \tau=t-(1 / m) \sum_{i=1}^{m} \boldsymbol{S}_{i}^{-} / x_{i 0}
$$




$$
\begin{gathered}
\text { Sujeito a } 1=t+(1 / s) \sum_{r=1}^{s} \boldsymbol{S}_{r}^{+} / y_{r 0}, \\
\boldsymbol{t} x_{0}=X \boldsymbol{\Lambda}+\boldsymbol{S}^{-}, \\
\boldsymbol{t} y_{0}=Y \boldsymbol{\Lambda}+\boldsymbol{S}^{+}, \\
\boldsymbol{\Lambda} \geq 0, \boldsymbol{S}^{-} \geq 0, \boldsymbol{S}^{+} \geq 0 \text { e } t>0 .
\end{gathered}
$$

A solução ótima de $\left(\tau^{*}, \mathrm{t}^{*}, \Lambda^{*}, \mathrm{~S}^{-*}, \mathrm{~S}^{+*}\right)$ é dada por:

$$
\rho^{*}=\tau^{*}, \lambda^{*}=\Lambda^{*} / t^{*}, s^{-*}=S^{-*} / t^{*}, s^{+}=S^{+*} / t^{+}
$$

Baseado nessa solução, define-se uma DMU $\left(\mathrm{x}_{0}, \mathrm{y}_{0}\right)$ como eficiente, no modelo SBM, quando $\rho^{*}=1$. 


\section{Método}

A presente dissertação foi idealizada para analisar a eficiência das rotas e corredores de transporte de soja, levando em consideração os três pilares da sustentabilidade (econômico, social e ambiental), assim como Panagakos (2016), dando passos iniciais para atingir os conceitos de corredores verdes e de economia circular.

O método foi pensado para abranger os seguintes passos: pesquisa bibliográfica; determinação de rotas, corredores e variáveis; coleta de dados; análise dos dados; aplicação da DEA-SBM; análise dos resultados; discussão e conclusões finais. Os próximos subtópicos apresentam cada uma dessas etapas detalhadamente.

\subsection{Sobre a Pesquisa Bibliográfica}

A análise DEA deve identificar claramente o que se espera como resultado, para que se possa fazer uma escolha acertada das variáveis. Como ponto de partida para proposição das variáveis e escolha de um modelo, foi realizada uma busca no banco de dados Scopus, com as palavras-chaves Logistics e Data Envelopment Analysis, sem filtro de tempo, resultando em 160 artigos. Após a leitura dos abstracts dos mesmos, 66 foram julgados relacionados direta ou indiretamente com o tema do presente projeto. Entende-se como indiretamente ligado ao tema proposto aqueles que aplicavam a DEA para medir a eficiência de apenas um dos elos da cadeia logística, normalmente portos (TONGZON, 2001; JIANG e LI, 2009; HARALAMBIDES e GUJAR, 2012).

No caso, a maioria absoluta dos artigos estava indiretamente relacionada a esta proposta. Explanando brevemente sobre os artigos mais relevantes, Chow, Heaver e Herinksson (1994) fazem uma revisão de literatura nos dois principais jornais de logística de 1982 a 1992, buscando trabalhos focados em desempenho logístico. Ele identifica cinco trabalhos anteriores que usaram DEA. Não foi possível acessar esses artigos diretamente mas, segundo Chow, Heaver e Herinksson (1994), eles são todos de 1989 a 1992, quatro usam dados de uma firma da cadeia (e aferem a eficiência) e um utiliza simulação. Chow, Heaver e Henriksson (1994) identificam como limitação comum a todos os trabalhos a dificuldade de aceso a dados e o viés da avaliação, uma vez que os dados foram colhidos de apenas um elemento da cadeia, normalmente, apenas o produtor. 
Kengpol, Tuamme e Tuominen (2014) utilizaram DEA para um problema de rotas de transporte de carga. Eles aplicaram DEA para determinar a rota multimodal mais eficiente no transporte de mercadorias da Tailândia até o Vietnã. O projeto de pesquisa aqui proposto difere de Kengpol, Tuamme e Tuominen (2014) por considerarem a DEA na eficiência global da rota e não apenas na minimização dos riscos. Oliveira e Cicolin (2016) são os primeiros autores a usarem DEA para medir eficiência de rotas. Seu projeto de pesquisa foi desenvolvido de modo independente e simultâneo ao presente trabalho. Os autores aplicam o modelo BCC a rotas brasileiras originárias do estado de Mato Grosso e com destino a portos nas regiões Norte, Nordeste, Sudeste e Sul do país. A escolha de variáveis foi orientada pelo método Balanced Scorecard (BSC).

\subsection{Sobre a Determinação de Rotas e Corredores}

Para a coleta de dados e definição precisa das rotas, o estudo se limitou aos corredores nacionais de cada país estudado, diferentemente de Panagakos (2016) que aplica seu estudo a corredores internacionais europeus. A coleta de dados foi feita em diversas fontes, mesmo considerando um país único, pois os corredores de exportação são afetados e regulamentados por diversas agências.

$\mathrm{O}$ ano de safra começa no dia 1 de setembro e termina no dia 31 de agosto do ano seguinte. Para ambos os países a nomenclatura "safra de 2013" refere-se ao ano de safra que começou no dia 1 de setembro de 2013. Essa safra foi escolhida por ser a mais recentemente completada e, pela ausência de evento climático atípico que pudesse afetar a interpretação dos resultados.

Foram determinadas 72 rotas no contexto brasileiro e 30 rotas no contexto norteamericano. As rotas receberam um código com a seguinte lógica:

- Todas as rotas foram numeradas. A numeração começa em 1, em cada país e segue um crescimento ascendente unitário;

- Toda rota que tem a presença do modal rodoviário recebe a letra R;

- Toda rota que tem a presença do modal ferroviário recebe a letra F;

- Toda rota que tem a presença do modal hidroviário recebe a letra $\mathrm{H}$;

- Para diferenciar as rotas norte-americanas das brasileiras, as primeiras começam com a letra E. 
Um corredor foi definido como um conjunto de rotas que partem do mesmo estado e terminam no mesmo porto exportador.

\subsection{Sobre a Escolha de Variáveis e a Coleta de Dados}

O Quadro 2 sumariza as variáveis utilizadas por trabalhos similares desenvolvidos anteriormente.

Quadro 2 - Trabalhos conhecidos sobre comparação de rotas e corredores.

\begin{tabular}{|c|c|c|c|}
\hline Trabalhos & Objetivo & Ferramenta & Variáveis \\
\hline Panagakos (2016) & $\begin{array}{l}\text { Desenvolver um método para } \\
\text { comparação de corredores, } \\
\text { baseado nas três dimensões da } \\
\text { sustentabilidade (econômica, } \\
\text { social e ambiental). }\end{array}$ & $\begin{array}{l}\text { Key Performance } \\
\text { Indicators } \\
\text { (KPI's). }\end{array}$ & $\begin{array}{l}\text { Origem-destino, tipo de carga } \\
\text { movimentada, modal utilizado, } \\
\text { rotas utilizadas, desequilíbrio } \\
\text { comercial (maior } \\
\text { disponibilidade de carga em } \\
\text { um sentido do que no outro). }\end{array}$ \\
\hline $\begin{array}{l}\text { Texas Transport } \\
\text { Institute } \\
\text { (TTI, 2007) (TTI, } \\
\text { 2012) }\end{array}$ & $\begin{array}{l}\text { Determinar o impacto que uma } \\
\text { seca no Rio Mississipi causaria } \\
\text { nos demais modais norte- } \\
\text { americanos para escoar sua } \\
\text { produção. }\end{array}$ & $\begin{array}{l}\text { Desenvolve um } \\
\text { método para } \\
\text { comparar } \\
\text { diferentes } \\
\text { modais. } \\
\end{array}$ & $\begin{array}{l}\text { Capacidade de transporte, } \\
\text { congestionamentos, emissões, } \\
\text { eficiência energética de cada } \\
\text { modal, impactos na segurança } \\
\text { e impactos na infraestrutura. }\end{array}$ \\
\hline $\begin{array}{l}\text { Marquez e } \\
\text { Cantillo (2013) }\end{array}$ & $\begin{array}{l}\text { Determinar os custos internos e } \\
\text { externos de rotas transporte } \\
\text { colombinas considerando os três } \\
\text { modais (rodoviário, ferroviário e } \\
\text { hidroviário fluvial). }\end{array}$ & $\begin{array}{l}\text { Modelo } \\
\text { desenvolvido por } \\
\text { instituição } \\
\text { colombiana. }\end{array}$ & $\begin{array}{l}\text { Tempo e operações (custos } \\
\text { internos), congestionamentos, } \\
\text { acidentes, poluição do ar e } \\
\text { acidentes (custos externos). }\end{array}$ \\
\hline $\begin{array}{l}\text { Kengpol, } \\
\text { Tuammee e } \\
\text { Tuominen (2014) }\end{array}$ & $\begin{array}{l}\text { Desenvolver uma ferramenta } \\
\text { que permita a escolha da rota } \\
\text { com menor risco de perda de } \\
\text { carga entre Tailândia e China. }\end{array}$ & $\begin{array}{l}\text { Ferramenta } \\
\text { desenvolvida } \\
\text { com aplicação } \\
\text { conjunta de DEA } \\
\text { e AHP. } \\
\end{array}$ & $\begin{array}{l}\text { Tempo, custo de frete, } \\
\text { emissões. }\end{array}$ \\
\hline $\begin{array}{l}\text { Oliveira e Cicolin } \\
(2016)\end{array}$ & $\begin{array}{l}\text { Comparar eficiência de rotas de } \\
\text { escoamento de milho a partir do } \\
\text { Mato Grosso até os principais } \\
\text { portos brasileiros. }\end{array}$ & $\begin{array}{l}\text { Escolha das } \\
\text { variáveis com } \\
\text { Balanced } \\
\text { Scorecard (BSC), } \\
\text { comparação das } \\
\text { rotas com DEA- } \\
\text { BCC. }\end{array}$ & $\begin{array}{l}\text { Custos logísticos, tempo, } \\
\text { emissões, matriz de transporte, } \\
\text { disponibilidade de armazéns, } \\
\text { custo da produção de milho, } \\
\text { fila nos portos/navios, extensão } \\
\text { da rota, custo de transporte, } \\
\text { velocidade de transporte, } \\
\text { consumo de combustível e } \\
\text { idade da frota. }\end{array}$ \\
\hline
\end{tabular}

Dado o contexto apresentado e a disponibilidade de dados, optou-se por buscar as seguintes variáveis, representando os três pilares da sustentabilidade:

- Soja transportada: assumido igual à soja colhida, as referências foram citadas no subtópico 3.2. Sobre a Determinação de Rotas e Corredores (pilar econômico);

- Diesel consumido: calculado (pilar econômico); 
- Capacidade estática de armazenamento dentro e fora das fazendas (pilar econômico);

- Área plantada: coletado (pilar econômico);

- Emissões: calculado (pilar ambiental);

- Fator de descarte: calculado visando a introduzir o conceito de economia circular (pilar ambiental);

- Fatalidades: estimado a partir de dados reais (pilar social);

- Extensão da rota: variável não controlável que pode afetar as demais.

Lembrando que esta dissertação optou pelo modelo SBM porque ele permite a maximização dos outputs e a minimização dos inputs simultaneamente, além de ser invariante à escala. No presente subtópico são descritas as coletas de dados (não descritos anteriormente) e cálculos das variáveis. Todos os dados das variáveis utilizadas estão na Tabela 17 do Apêndice A.

\subsubsection{Consumo de Combustível}

Não foi fisicamente possível coletar dados diretos sobre o consumo de combustível para tantas rotas distintas nos dois países estudados com tantas empresas participantes. Optou-se pela estimativa indireta. Isto é, uma abordagem de baixo para cima (bottom-up), ou seja, modelando a atividade de transporte (usando as rotas e modais já estabelecidos) e usando fatores de conversão de eficiência energética (KONTOVAS; PSARAFTIS, 2016).

Para entender os métodos de estimativa é fundamental compreender o conceito de tonelada-quilômetro, equivalente à tonelada-milha. Os dados dos EUA estavam na unidade volumétrica bushel e os dados do Brasil estavam na unidade de massa tonelada. Escolheu-se trabalhar com a unidade tonelada. Para realizar a conversão de bushel de soja para tonelada foram adotadas as recomendações do Canada Grains Council (2000). Portanto, todas as unidades em bushel foram divididas pelo bushel equivalente de soja $(36,7440)$ para se obter o valor em toneladas. Tonelada-quilômetro é um indicador internacionalmente reconhecido que representa o trabalho relativo ao deslocamento de uma tonelada de carga à distância de um quilômetro (EPE, 2012). 
Em Baumel (2011), há uma comparação da assertividade na estimativa de cálculo de consumo de combustível para o transporte de carga a granel por meio dos modais rodoviário, ferroviário, hidroviário. $\mathrm{O}$ autor compara cinco métodos:

1. Uso de dados agregados para estimar a tonelada milha por galão (NTMG, net-ton miles per gallons, em inglês) por modal;

2. Estimativa da NTMG por segmento do rio e por direção do movimento do trem;

3. Estimativa da NTMG por características operacionais;

4. Estimativa da NTMG por tipo de produto transportado;

5. Estimativa do consumo de combustível usando a NTMG e milhas percorridas por modal de uma origem específica para destinos finais específicos.

Baumel (2011) concluiu que o quinto método é o que leva a resultados mais precisos e alerta que as demais podem conduzir a distorções. No entanto, assim como coletar dados diretos se revelou inviável, o cálculo específico para cada rota teria que considerar características específicas de cada trajeto a cada $100 \mathrm{~km}$ para ambos os países (Brasil e EUA), como o desenvolvido por Baumel, Hurburgh e Lee (2015) para as rotas e modais que levam grãos de Iowa à China. Isso está fora do escopo de viabilidade deste projeto, devido a limitações físicas e financeiras.

A conclusão de Baumel (2011) vai ao encontro do trabalho de Bartholomeu e Caixeta Filho (2009) que relaciona a condição das rodovias brasileiras ao consumo de combustível e emissão de $\mathrm{CO}_{2}$.

Adotou-se a primeira abordagem, ou seja, o uso de dados agregados. Segundo Baumel (2011), a primeira tentativa de determinar valores de tonelada-quilômetro para cada modal de transporte, independentemente da carga transportada e da rota, foi feita pelo Departamento de Transporte Norte-Americano em 1979. Eles estimaram que o modal hidroviário (restrito aos rios) possuía de 243,3 a 639 NTMG Net-Ton Miles per Gallons (NTMG), isto é, tonelada bruta milha por galão, unidade semelhante a tonelada quilômetro por litro, e modal ferroviário possuía 138,5 a 693,5 NTMG.

Segundo Baumel (2011, apud Eastman (1980)), esses valores foram revisados logo em seguida para rodoviário 59 NTMG, ferroviário 202 NTMG e hidroviário 514 NTMG. Baumel (2011) se baseou no relatório técnico da Texas Transportation Instrument (TTI, 2007): rodoviário, 155 NTMG; ferroviário, 413 NTMG e hidroviário, 576. 
O relatório do Texas Transportation Instrument (TTI, 2007), um relatório detalhado sobre a eficiência modal das rotas norte-americanas, visando à promoção do modal hidroviário, aborda a capacidade de carga de cada modal, congestionamentos, emissões, eficiência energética, impactos de segurança e impactos na infraestrutura das vias.

A questão da tonelagem-quilômetro está inserida dentro da questão da eficiência energética. O relatório mais recente da TTI (2012) atualiza valores que se alteraram devido às mudanças tecnológicas, mas mantém o mesmo método do relatório anterior (TTI, 2007). A Tabela 2 mostra a essa evolução dos valores de 2007 para 2012, a conversão para tonelada-quilômetro e que tipo de composição modal o relatório considerou como referência de cálculo.

Tabela 2 Valores compilados para eficiência energética de cada modal.

Eficiência Energética

\begin{tabular}{|c|c|c|c|c|}
\hline Composição & Capacidade de Carga (t) & Ano & mi.-t./gal. & km-t./l \\
\hline \multirow{2}{*}{15 Barcaças e 3 Reboques } & \multirow{2}{*}{26250} & 2007 & 576 & 245 \\
\hline & & 2012 & 616 & 262 \\
\hline \multirow{2}{*}{108 Vagões e 3 Locomotivas } & \multirow{2}{*}{11880} & 2007 & 413 & 176 \\
\hline & & 2012 & 478 & 204 \\
\hline \multirow{2}{*}{ Caminhão } & \multirow{2}{*}{25} & 2007 & 155 & 66 \\
\hline & & 2012 & 150 & 64 \\
\hline
\end{tabular}

Fonte: Elaborada pela autora, baseado em TTI (2007) e TTI (2012).

Para o caso norte-americano foram adotados os valores de TTI (2012), que também são aceitos para os cálculos realizados pela União de Transportadores de Soja dos EUA (SOY TRANSPORTATION COALITION, 2016).

Não foi encontrado um estudo semelhante para o cenário brasileiro. Para o modal rodoviário, assumiu-se que o veículo utilizado para a modelagem seria um caminhão trucado com reboque (cinco eixos), cuja capacidade é de 43 toneladas (CONTRAN, 1999).

Para as hidrovias, buscaram-se dados reais da frota da Lagoa dos Patos (ALIANÇA, 2016) e da Paraná-Tietê (AHRANA, 2012). Assumiu-se para o modelo que, enquanto uma composição média, nos EUA, possui 15 barcaças, cada uma carregando 1620 toneladas. No Brasil, uma composição média possui apenas 3 barcaças transportando 1287 toneladas cada.

Para as ferrovias nos EUA, o relatório TTI (2016) considera uma composição composta por três locomotivas e 108 vagões. O relatório Soy Transportation Coalision 
(2016) considera uma composição composta por 100 vagões e não especifica o número de locomotivas necessárias. Já Quorum Coorporation (2005) explica que, em casos de excelência, duas locomotivas podem puxar 100 vagões, transportando 119, 3 toneladas no total. Para o caso brasileiro, baseado em Petroli (2014), menciona-se que a ALL parte do terminal de Rondonópolis, polo agrícola do maior estado brasileiro produtor de soja (Mato Grosso), com composições de 80 vagões. Isso foi adotado como padrão para o modelo.

Uma vez que todos os valores de eficiência energética já estavam estabelecidos para o caso norte-americano, foi necessário estabelecer valores para o caso brasileiro. Para o caso rodoviário, usou-se o relatório da Conab (2016), que menciona que um caminhão Volvo/FH 460 6x2 de 32 toneladas (semelhante ao modelo considerado neste estudo) percorre 2,4 km/l. Especialistas consultados falam em 2,0 km por litro para um caminhão carregado. Em prol da segurança, adotou-se 2,0 km por 1. Para isso considerase 86 t.-km/l para eficiência energética de um caminhão brasileiro.

Já no caso hidroviário, os reboques das frotas analisadas no Brasil têm mais de 65 anos e o Brasil possui um número muito pequeno de barcaças na composição (duas ou três). Considerando que os dois países tivessem reboques iguais e a diferença fosse só a carga da Hidrovia Paraná-Tietê, o Brasil teria uma eficiência energética igual a $14 \%$ da norte-americana. Se isso fosse realístico, provavelmente o transporte de carga por hidrovias seria um negócio inviável. Adotou-se, então, a carga de uma barcaça da Lagoa dos Patos, 3.660 toneladas, e considerou-se uma composição com três barcaças, resultando em uma eficiência de 110 t.-km/l, cerca de $40 \%$ da eficiência norteamericana, mais próxima do modal ferroviário.

Pelo relatório Quorum Cooportation (2005) e pelo relatório detalhado da frota brasileira de locomotivas de Neves (2012), é possível estimar que os EUA estão considerando 3 locomotivas com potência de 4500 HP enquanto, no Brasil, estão sendo considerada 4 locomotivas de 2000 HP. No total, os comboios americanos têm uma potência gerada $13500 \mathrm{HP}$ e os brasileiros de $10000 \mathrm{HP}$. Considera-se que os EUA puxam uma tonelada-milha com $0,8 \mathrm{HP}$ enquanto os brasileiros precisam de $1 \mathrm{HP}$. A eficiência norte-americana é de $20 \%$ a $30 \%$ maior. Para o Brasil, estimou-se $25 \%$, isto é, 153 t.-km/l.

A Tabela 3 compila os valores de eficiência energética considerados para os dois países. 
Tabela 3 Valores de eficiência energética adotados por modal para o modelo.

\begin{tabular}{lcc}
\hline \multirow{2}{*}{ Modal de Transporte } & Eficiência Energética (km-t./l) \\
\cline { 2 - 3 } & EUA & Brasil \\
\hline Composição Barcaças & 262 & $39^{*}$ \\
\hline Composição Vagões & 204 & $153^{*}$ \\
\hline Caminhão & 64 & $86^{*}$ \\
\hline
\end{tabular}

Fonte: Elaborada pela autora baseada em TTI (2012). O símbolo * indica estimativa da autora.

\subsubsection{Emissões}

A análise tradicional de corredores envolve relações de custo benefício, relações econômicas e outros critérios de otimização. Com o conceito de logística verde, é preciso que essa análise englobe também dimensões sociais e ambientais (KONTOVAS; PSARAFTIS, 2016).

Para o caso das emissões, a autoridade global mais respeitada é o Intergovernamental Panel on Climate Change (IPCC). Para seus cálculos, o órgão assume os dois pressupostos do Protocolo de Kyoto, isto é: (1) aquecimento global existe e (2) as emissões de $\mathrm{CO}_{2}$ provocadas pela atividade humana causam esse aquecimento (KONTOVAS e PSARAFTIS, 2016).

$\mathrm{O}$ setor de transportes emite poluentes que não são $\mathrm{CO}_{2}$ e que também influenciam o clima. Isso inclui $\mathrm{CH}_{4}, \mathrm{NO}_{\mathrm{x}}, \mathrm{SO}_{2}, \mathrm{CO}$, gases $\mathrm{F}$, carbono negro e aerossóis não absorvíveis. Sem entrar em detalhes, existem emissões que contribuem para o aquecimento global e outras para o resfriamento. Existe o conceito de unidades $\mathrm{CO}_{2}$ equivalente, que expressa a ideia de equivalência entre diversos gases causadores do efeito estufa em emissões de $\mathrm{CO}_{2}$ proporcionais (KONTOVAS e PSARAFTIS, 2016).

Existem duas abordagens para o cálculo de emissões, a de cima para baixo (topdown) e a de baixo para cima (bottom-up). Também conhecida como método baseado em consumo, a abordagem de cima para baixo usa o consumo de combustível para estimar as emissões. Seus resultados são tidos como mais confiáveis de modo geral. Já a abordagem de baixo para cima, conhecida também como método baseado em atividade, usa a atividade da frota, como ponto de partida do cálculo (KONTOVAS e PSARAFTIS, 2016).

Para a abordagem de cima para baixo, foi utilizada a Equação 2.

\section{Emissões $=($ Consumo de Energia ou Combustível $) \times$ Fator de Emissões}

Equação 2 - Estimativa de emissões na abordagem de cima para baixo. 
As estimativas de emissões baseadas em dados do consumo real de combustível são mais acuradas. Neste caso, podem-se usar fatores de emissões baseados em observações empíricas. Esses fatores dependem de três condições: (1) o tipo de combustível, (2) o conteúdo de enxofre e (3) o tipo de motor. Uma ampla variedade de fontes para fatores de emissões pode ser usada para estimar as emissões das atividades de transporte. Entre elas, destacam-se as dos órgãos governamentais dos EUA (US Environment Protection Agency, EPA), do Reino Unido (UK Department for Environment, Food and Rural Affairs) e da União Europeia (European Environment Agency) (KONTOVAS e PSARAFTIS, 2016).

Algumas vezes, dados de consumo de combustível não estão disponíveis ou é irreal estimar emissões pela abordagem de cima para baixo. Neste caso, modela-se a atividade de transporte ou usam-se fatores de conversão para converter os dados disponíveis em emissões. Essa é a abordagem de baixo para cima (KONTOVAS e PSARAFTIS, 2016).

Para se estimar as emissões com a abordagem de baixo para cima, utiliza-se a Equação 3.

$$
\text { Emissões de } \mathrm{CO}_{2}=\mathrm{V} \times \mathrm{D} \times \mathrm{F}
$$

Equação 3 - Estimativa de emissões na abordagem de baixo para cima.

Sendo:

$\mathrm{V}$ : volume transportado (em toneladas);

D: a distância percorrida (em quilômetros); e

F: o fator médio de emissões por tonelada-quilômetro.

O presente trabalho optou pela abordagem de baixo para cima devido à restrição de disponibilidade de dados. Obviamente existem divergências entre os resultados das duas abordagens. Essas diferenças são atribuídas a dados faltantes e a estatísticas irreais na abordagem de cima para baixo; e à aceitação de hipóteses irreais na abordagem de baixo para cima (KONTOVAS; PSARAFTIS, 2016).

Estimar um fator de emissões para ambas as abordagens não é uma tarefa trivial. Esse fator depende, entre outras coisas, principalmente do veículo, do modo como o veículo é conduzido (velocidade, carga, condições da via) e do clima. No caso da abordagem escolhida (de baixo para cima), as três principais agências governamentais 
têm suas próprias orientações metodológicas, seus próprios modelos e, em alguns casos, seus próprios softwares para estimativa de emissões. A US Environment Protection Agency (EPA) têm o software MOVES (Motor Vehicle Emissions Simulator) para veículos motorizados e o NONROAD para veículos não motorizados. A European Environment Agency (EEA) usa o software EcoTransIT (KONTOVAS; PSARAFTIS, 2016).

O relatório Texas Transportation Instrument (2012) usa o software MOVES versão 2010a para modelar o fator de emissões. Sua modelagem é focada em apenas quatro poluentes primários: compostos voláteis orgânicos, monóxido de carbono $\left(\mathrm{CO}_{\mathrm{x}}\right)$, dióxido de carbono $\left(\mathrm{CO}_{2}\right)$, óxido de nitrogênio $\left(\mathrm{NO}_{\mathrm{x}}\right)$ e particulados com diâmetro inferior a 10 mícrons. O modelo considera que os modais vão carregados e voltam vazios. Após uma ampla explanação sobre as regulamentações aplicáveis, o relatório acaba concluindo que as emissões são função do total de combustível queimado, independentemente dos demais fatores. Portanto, para calcular o peso das emissões basta multiplicar o peso do carbono no diesel $(0,736 \mathrm{~g} / \mathrm{l})$ pelo percentual de carbono no dióxido de carbono $(0,99)$, pelo peso molecular do carbono (44/12). Portanto, por $2,67 \mathrm{~g} / 1$.

Esse fator é encontrado como multiplicador para caminhão movido a diesel, de acordo com as orientações metodológicas de Greenhouse Gas Protocol (2016). Este documento resultou de uma parceria entre o World Resource Institute (WRI) e o World Business Council on Sustainable Development (WBCSD) em prol do desenvolvimento de regras globais sobre como medir, gerenciar e reportar emissões de gases do efeito estufa.

O presente trabalho adotou os fatores de conversão propostos pelo Greenhouse Gas Protocol (2016), conforme sumarizado na Tabela 4 e na Tabela 5.

Tabela 4 Fator de conversão para cálculo das emissões de caminhões articulados.

\begin{tabular}{|c|c|c|c|c|c|c|c|}
\hline $\begin{array}{c}\text { Tipo de } \\
\text { Caminhão }\end{array}$ & T.-km & $\mathbf{X}$ & $\begin{array}{l}\text { Litros por } \\
\text { quilômetro }\end{array}$ & $\mathbf{X}$ & $\begin{array}{c}\text { Fator de } \\
\text { conversão do } \\
\text { combustível } \\
\text { (diesel) }\end{array}$ & $=$ & $\begin{array}{c}\text { Total de kg } \\
\mathrm{CO}_{2}\end{array}$ \\
\hline Articulado & & $X$ & $0,5 *$ & $X$ & $2,67 * *$ & $=$ & \\
\hline
\end{tabular}

Fonte: Elebarodo pela autora, baseado em Greenhouse Gas Protocol (2016), quando indicado por * e baseado em TTI (2012) quando indicado por **.

Tabela 5 Fator de conversão para cálculo das emissões de locomotivas e barcas. 


\begin{tabular}{|c|c|c|c|c|}
\hline Tipos de Transporte & Ton-km & $\mathbf{X}$ & $\begin{array}{c}\text { Fator de } \\
\text { conversão }\end{array}$ & $=$ Total de $\mathrm{kg} \mathrm{CO}$ \\
\hline Trem (Locomotiva) & & $\mathrm{X}$ & 0,03 & $=$ \\
\hline Reboque (Small Bulk Carrier) & & $\mathrm{X}$ & 0,014 & $=$ \\
\hline
\end{tabular}

Fonte: Elaborada pela autora, baseado em Greenhouse Gas Protocol (2016).

O EcoTransIT é um software gratuito, inicialmente desenvolvido em parceria com uma empresa ferroviária na Alemanha. Apesar de sua origem ferroviária, ele calcula emissões e consumo de combustível para o modal rodoviário, ferroviário, aéreo e hidroviário (marítimo e fluvial), para qualquer rota do globo, segundo as normas vigentes na Europa. Basta informar as coordenadas de entrada e saída. O software também faz distinção entre as emissões do transporte de carga a granel e em containers (ECO TRANSIT WORLD, 2016). Para trabalhos futuros, recomenda-se o uso do software para comparação dos resultados.

\subsubsection{Capacidades estáticas de armazenamento dentro e fora das fazendas}

A capacidade de armazenamento afeta a capacidade logística porque a colheita da safra é sujeita aos efeitos da sazonalidade. Geralmente o escoamento se dá em período concomitante com a safra (de abril a setembro). Uma maior capacidade de armazenamento (interna e externa) a custo acessível permite o escoamento da safra em outros períodos do ano, possivelmente aproveitando cotações mais altas do produto. Segundo Oliveira et al. (2016), isso permite uma maior lucratividade para o produtor, além de, consequentemente, impactar na logística colocando menos veículos de transporte de carga num mesmo corredor num mesmo período. Dessa forma, reduz-se o risco de acidentes, perda de carga, desgaste das vias, custos com manutenção e aumenta-se a velocidade do tráfego.

Foi feita a escolha de trabalhar com duas variáveis de armazenamento (isto é, capacidade de armazenamento dentro e fora das propriedades rurais), ao invés de trabalhar com uma única variável, porque entende-se que os dois modos de armazenamento têm características distintas de uso, administração, custo e capacidade, portanto, devam ser alvo de diferentes programas governamentais de financiamento.

Comparativamente, o Brasil tem uma capacidade estática dentro das fazendas (11,3\% da capacidade nacional) inferior à encontrada em outros países (CONAB, 2005). 
Assume-se, portanto, que seja desejável uma maior capacidade estática dentro da fazenda, pois essa é uma prática global. Além de que, Peixoto, Ribeiro e Granemann (2016) demonstram que o Brasil é deficitário em ambas as capacidades de armazenamento e aponta isso como um dos cinco maiores gargalos para o escoamento de grãos nacionais. Desta forma, decidiu-se que é interessante maximizar a ambas as variáveis e deixá-las separadas para que se possa entender qual é mais prioritária para o aumento da eficiência e tem necessidade de maior foco de investimentos.

Oliveria e Cicolin (2016) consideram a disponibilidade de uma unidade armazenadora na rota, ou seja, a capacidade estática, mas não consideram a capacidade de estocagem por unidade armazenadora. O presente trabalho optou por usar a capacidade estática por unidade federativa. Para o Brasil, foram usados dados de IBGE (2016), mantendo-se a separação dos armazéns que ficavam dentro de propriedades rurais dos externos. Para os EUA, os dados foram retirados do NASS (2016) mantendose a mesma separação.

\subsubsection{Fator de descarte}

Nos últimos anos, o termo economia circular está sendo usado com maior frequência. Sua origem e definição são controversas. Para este trabalho, adota-se o conceito de (MURRAY; SKENE; HAYNES, 2015) para economia circular:

\footnotetext{
Um modelo econômico no qual planejamento, mobilização de recursos, contratos, produção e reprocessamento são projetados e gerenciados, simultaneamente como processo e produto, com o intento de maximizar o funcionamento do ecossistema e o bem-estar do ser humano.
}

De acordo com a Fundação Ellen MacArthur (2016), economia circular é um sistema produtivo restaurativo e regenerativo por objetivo e por projeto. A economia circular substitui o conceito de "fim-de-vida" com restauros, trocas de uso com energia renovável, eliminação do uso de produtos tóxicos (que impediam o reuso) e o objetivo de eliminar o desperdício por meio de um projeto mais adequado dos materiais, produtos, sistemas e, por último, modelos de negócios.

O presente trabalho está inserido dentro da questão de um modelo de negócios que já existe e não será redesenhado num horizonte previsível de tempo, exceto se 
eventos drásticos e inesperados ocorrerem, como, por exemplo, uma grande seca. Dentro deste contexto, surge o desafio de inserir os conceitos básicos da economia circular. As reflexões propostas, para desenvolvimento de uma variável que represente a economia circular foram: Quanto tempo o ciclo econômico da produção de soja vai durar? Numa perspectiva histórica, o Brasil já teve o ciclo econômico extrativista do pau-brasil, da cana de açúcar, do café entre outros. Após o término de um ciclo econômico, o que pode ser feito da infraestrutura de modal de transporte utilizada? Como mensurar o impacto do material descartado e/ou reutilizá-lo?

Para se representar este conceito no presente trabalho, criou-se o fator de descarte. $\mathrm{O}$ fator de descarte foi criado para representar a quantidade de elementos de transporte que será descartada num ciclo econômico de um século.

No caso brasileiro, considerou-se que a idade média da frota rodoviária é de 9,8 anos (ABIPEÇAS, 2011), da frota hidroviária fluvial é de 37,0 anos (ALIANÇA, 2016) e da frota ferroviária é de 37,1 anos (NEVES, 2012).

No caso norte-americano, considerou-se que a idade média da frota rodoviária é de 11,4 anos (BUREAU OF TRANSPORTATION STATISTICS, 2015), da frota hidroviária fluvial é de 22,0 anos (MURRAY, 2016) e da frota ferroviária é de 22,3 anos (STATISTA - THE STATISTICS PORTAL, 2016).

O fator de descarte foi desenvolvido por meio do produto de duas frações. A primeira fração representa o número de vezes que a frota daquele modal naquele país será descartada durante um século. A segunda fração representa o tamanho proporcional daquela frota na economia do país; ela é a divisão da quantidade de veículos necessária para o transporte (com aquele modal) da safra regional dividido pela quantidade de veículos necessária para o transporte (com o mesmo modal único) de toda safra nacional. A equação para o cálculo do fator de descarte está explicitada na Equação 4:

$$
F D=\frac{C E}{I F_{n}} \cdot \frac{T F_{r}}{T F_{n}}
$$

Equação 4 - Fórmula para cálculo do fator de descarte para modal único (proposta pela autora).

Onde:

$F D$ : Fator de descarte;

$C E$ : Duração do ciclo econômico em anos, no caso, adotado 100;

$I F_{n}$ : Idade média da frota nacional; 
$T F_{r}$ : Tamanho da frota necessária para o transporte da safra regional;

$T F_{n}$ : Tamanho da frota necessária para o transporte da safra nacional.

No caso de rotas com múltiplos modais, foi calculado o fator de descarte para cada modal e depois eles foram somados, resultando num fator de descarte total, conforme explicitado na Equação 5:

$$
F D_{M M}=F D_{R}+F D_{F}+F D_{H F}
$$

Equação 5 - Fórmula para o cálculo do fator de descarte para uma rota multimodal (proposta pela autora).

Onde:

$F D_{M M}:$ Fator de descarte de uma rota multimodal;

$F D_{R}:$ Fator de descarte do modal rodoviário;

$F D_{F}$ : Fator de descarte do modal ferroviário;

$F D_{H F}$ : Fator de descarte do modal hidroviário fluvial.

A Tabela 6 compila os dados considerados para o cálculo do fator de descarte para o ano base de 2016.

Tabela 6 Compilação dos valores considerados para o cálculo do fator de desgaste.

\begin{tabular}{lrlcl}
\hline & $\begin{array}{c}\text { Idade Média da } \\
\text { Frota (anos) }\end{array}$ & $\begin{array}{c}\text { Quantidade de Veículos Necessária para Transportar toda } \\
\text { Frota Nacional }\end{array}$ \\
\hline Veículo & Brasil & EUA & Brasil & EUA \\
\hline Caminhão & 9,8 & 11,4 & 1062791 & 2008000 \\
\hline Vagão & 37,0 & 22,3 & 571250 & 456364 \\
\hline Barcaça & 37,1 & 22,0 & 35509 & 30988 \\
\hline
\end{tabular}

\subsubsection{Fatalidades por modal de transporte}

Os dados da variável social, número de mortos em acidentes fatais por modal de transporte, foram retirados de diversas fontes. No caso brasileiro, para o modal rodoviário, foram retirados de DNIT (2010), considerando o total de acidentes em rodovias federais por estado e extensão das rodovias federais em cada unidade federativa. Como não existem estatísticas consolidadas para fatalidades em rodovias estudais e elas correspondem a cerca de $40 \%$ das rotas, utilizou-se um fator estimado. Para o modal ferroviário, utilizou-se o Relatório de Segurança do Instituto da 
Mobilidade e dos Transportes Terrestres (2011), que menciona 22 mortos em acidentes ferroviários no ano de 2010, excetuando-se casos de suicídio. Para o modal hidroviário fluvial, foi usado o levantamento da dissertação de mestrado de Ferreira (2000) para a Hidrovia do Paraná-Tietê, que relata uma média de quatro fatalidades por ano. Considerando-se que as hidrovias do Paraná-Tietê e Lagoa dos Patos sejam similares, assumiram-se oito fatalidades por ano para hidrovias brasileiras.

No caso norte-americano, para o modal rodoviário, utilizaram-se os dados do website do National Highway Traffic Safety Administration (2016), por estado, para o ano de 2010, contabilizando os mortos de todas as rodovias. Para o modal ferroviário, utilizaram-se os dados do website Federal Railroad Administration Office of Safety Analysis (2016), que relata 734 mortes no ano de 2010, sem especificar se os suicídios estão computados. Para o modal hidroviário, foram utilizados dados do website do Bureau of Transportation Statistics (2016), que relata 41 mortes no ano de 2010, em todas as hidrovias fluviais norte-americanas. Assume-se neste modelo que o risco de um acidente é diretamente proporcional à distância percorrida em cada rota por cada modal.

\subsection{6 Área plantada}

A área plantada por microrregião produtora foi considerada um input por ser a principal causadora da quantidade de soja transportada. Oliveira e Cicolin (2016) consideram a variável da produtividade, isto é, a quantidade colhida dividida pela área plantada. Os dados de área plantada foram coletados, para os EUA, em NASS (2016) e, para o Brasil, em CONAB (2014).

\subsubsection{Limitações da proposta}

O presente modelo considera que todas as rotas são escolhidas sem discriminação. No caso de uma rota ser preferida às outras, hipoteticamente, esse movimento vai até a formação de congestionamento nessa via. Logo em seguida, as rotas alternativas passam a ser igualmente utilizadas, retornando ao equilíbrio de distribuição de rotas.

O presente modelo não considera o fluxo de retorno. É possível que existam rotas essencialmente exportadoras, onde não existam mercadorias a serem transportadas no sentido de retorno. Isso pode inviabilizar economicamente determinadas rotas. 


\section{Resultados e Discussão}

Este tópico está dividido em duas partes. A primeira apresenta as etapas intermediárias de construção e definição das rotas. A segunda parte apresenta os resultados do modelo DEA de todas as rotas analisadas em conjunto, sua análise estatística e a abordagem proposta para análise dos corredores brasileiros nas regiões Centro-Oeste, Sudeste e Sul.

\subsection{Ponto de partida para interpretação dos resultados}

Este subtópico se divide na definição de rotas no contexto brasileiro e norteamericano.

\subsubsection{Contexto brasileiro}

No Brasil, os maiores estados produtores de soja são: Mato Grosso, Paraná, Rio Grande do Sul, Mato Grosso do Sul e Goiás (SALIN, 2016). As rotas brasileiras têm por origem as microrregiões mais produtoras desses estados. Os pontos de destino foram os portos de maior destaque nas exportações conforme descrito na Tabela 1. A produção de soja por microrregião foi obtida de diferentes entidades estaduais, conforme descrito abaixo. Sempre que possível, as distâncias percorridas foram obtidas das mesmas fontes. Em alguns casos, as distâncias foram estimadas utilizando o aplicativo Google Earth (GOOGLE COMPANY, 2016).

- Mato Grosso: O Instituto Mato-Grossense de Economia Agropecuária (IMEA) subdivide o estado em sete macrorregiões conforme sua relevância econômica (IMEA, 2011). Além disso, a instituto acompanha todas as safras, dos custos de produção e dos mercados nacional e internacional de soja. A entidade emite boletins semanais e relatórios mensais. Os dados das safras de 2013 e 2014 foram retirados de Boletim Semanal de Soja IMEA (2015).

Considerando-se a classificação do IMEA (2011) para macrorregiões e polos econômicos, as três maiores produtoras da safra foram: Médio-Norte (produção de 9.836.300 toneladas, principal polo econômico é o município de Sorriso), Sudeste (5.866.300 t., Primavera do Leste) e Nordeste (4.141.338 t., Canarana). Nos últimos 
anos têm aumentado o escoamento da produção do norte do estado pelo modal rodoviário até Miritituba (PA) e, a partir de lá, pelo modal hidroviário (Rio Araguaia) até o porto de Vila do Conde (PA) (CDP, 2015). Embora esse projeto tenha sido tema de ampla cobertura nas mídias especializadas, com o nome de 'Corredor Norte Sul' (PEREIRA; CASTRO, 2014), optou-se, no passo inicial, em focar apenas nas rotas mais consolidadas, ou seja, as rotas para os portos de Santos e Paranaguá.

Por meio de relatório Projeto Centro-Oeste Competitivo (MACROLOGÍSTICA, 2013), identificou-se que todos os polos econômicos utilizam rotas rodoviárias para ambos os portos. Os corredores unicamente rodoviários são chamados de " $R$ " e um algarismo identificador.

Além disso, Mato Grosso também conta com o escoamento ferroviário, a partir dos municípios Alto Araguaia (MT) e Rondonópolis. É necessário o transporte rodoviário até lá. Os corredores que utilizam esses dois modais são chamados de "RF" e seguidos de um número identificador. A empresa ferroviária operadora é única (RUMO ALL), o terminal do Alto Araguaia, Malha Norte da RUMO ALL, é operado pelas empresas Cargill, Mosaic Fertilizantes, Galvani e Bunge, tem capacidade de descarga de 333.518 TU/mês e capacidade de carregamento de 652.573 TU/mês (RUMO ALL, 2015). Lembrando que TU é abreviatura de Tonelada Útil Tracionada, isto é, o total de carga movimentada na malha, no transporte remunerado. Não foram encontrados dados oficiais sobre o terminal de Rondonópolis. A Figura 23 mostra malha ferroviária, de acordo com website governamental Infraestrutura Nacional de Dados Espaciais (INDE), provavelmente atualizado em 2014. Na Figura 23, a posição de Rondonópolis foi marcada com um círculo vermelho e de Alto Araguaia com um círculo azul. Além disso, vê-se, na mesma figura, o trecho final da Hidrovia Paraná-Tietê em azul. 


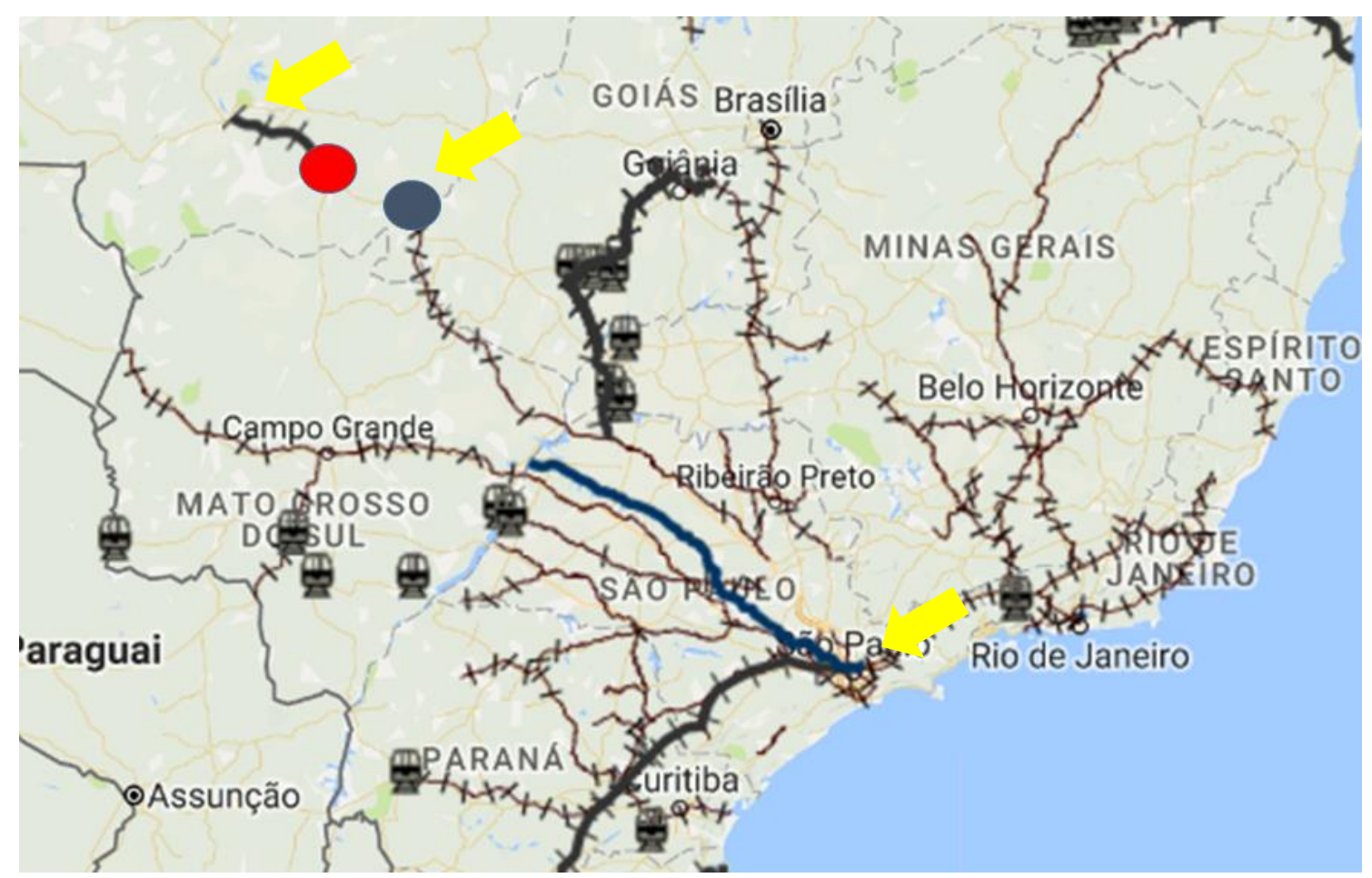

Figura 23 - Malha ferroviária que alcança Mato Grosso. Pontos de origem e principal porto de destino marcados com uma seta amarelo.

Fonte: Elaborada pela autora a partir do visualizador de Infraestrutura Nacional de Dados Espaciais (INDE, 2017).

Mato Grosso também tem a opção de escoamento hidroviário por meio do porto de São Simão (GO). A Hidrovia Paraná-Tietê é de responsabilidade da agência governamental AHRANA, subordinada à ANTAQ. Segundo relatório da mesma (AHRANA, 2012), no terminal de São Simão operam as empresas ADM, Caramuru, Nova Roseira, Louis Dreyfus e DNP e as principais empresas de navegação são a SARTCO, PBV, Louis Dreyfus, Mineração Mercantil, COINBRA, DNP, Cia. de Navegação da Amazônia e Navegação Diamante.

Segundo o Relatório de Movimentação de Carga (AHRANA, 2013), o deslocamento de soja partindo de São Simão (GO), Tramo Norte da hidrovia, teve como destino, para aproximadamente $60 \%$ da carga, a cidade de Pederneiras (SP); para cerca de $30 \%$, a cidade de Anhembi (SP) e o restante para a cidade de Santa Maria da Serra (SP).

O terminal de Pederneiras, operado pelas empresas Caramuru-DNP e COINBRA (AHRANA, 2005), tem conexão com modal ferroviário até o porto de Santos. A rota ferroviária também é explorada por empresa única, RUMO ALL, Malha Paulista (RUMO ALL, 2015). Essa opção de corredor de exportação foi chamada "RHF" seguida de um algarismo identificador. 
Os terminais de Anhembi e Santa Rita da Serra contam apenas com conexões rodoviárias. Os Terminais de Granel de Anhembi (várias empresas) são atendidos pela DNP, enquanto Santa Maria da Serra tem um terminal único da empresa ADM (AHRANA, 2005). Essa opção de corredor de exportação foi chamada de "RHR" seguida de um algarismo identificador. Em caso de dúvida sobre a localização dos terminais hidroviários, consulte a Figura 9 (Trechos IV e III da Hidrovia).

Totalizando, o estado de Mato Grosso conta com 21 rotas de exportação consolidadas, ligando as três macrorregiões que mais produziram soja com os dois principais portos exportadores.

- Paraná: Os dados da safra foram retirados da homepage da Secretaria da Agricultura e do Abastecimento do Paraná (SEAB, 2015). O documento precisava a tonelagem da primeira e da segunda safra de um mesmo ano, por macrorregião. Para o presente estudo, foi considerado o valor total da safra em um ano (somatória de ambas as safras).

Considerando-se a divisão geográfica do IBGE (IBGE, 2015), os maiores municípios da safra estudada (Londrina, Guarapuava e Cascavel) estão localizados, respectivamente, nas mesorregiões Norte Central, Centro Sul e Oeste. Não foram encontrados estudos acadêmicos de caracterização do escoamento de soja no Paraná, como os disponíveis para Mato Grosso (OJIMA, 2004) e Goiás (VIEIRA, 2002), sendo esse um tema relevante para futuros trabalhos de caracterização.

Para determinação das rotas mais utilizadas, tomou-se como base o relatório Sul Competitivo (MACROLOGÍSTICA, 2011), considerou-se que os três polos escoam para o porto de Paranaguá (preferencialmente) e de Santos. O Porto de São Francisco do Sul (SC) foi desconsiderado devido a sua participação no escoamento ser significativamente inferior aos anteriores (ibid.).

Além das rotas rodoviárias, o Paraná ainda conta com a operação de duas empresas ferroviárias, a RUMO ALL (RUMO ALL, 2015) e estatal Ferroeste, que liga Cascavel a Guarapuava (FERROESTE, 2016). Totalizando, no Paraná, foram determinadas seis rotas rodoviárias e três rotas exclusivamente ferroviárias.

- $\quad$ Rio Grande do Sul: Os dados da safra foram conseguidos no site da Empresa de Assistência Técnica e Extensão Rural do Governo do Rio Grande do Sul (EMATER, 2014). O relatório apresenta a área plantada e produtividade média por município. A produção por município foi calculada multiplicando-se ambos os dados. 
Considerando-se a divisão do IBGE (IBGE, 2015), os municípios que mais produziram nesta safra (Ijuí, Santa Maria e Bagé) estão localizados, respectivamente, nas mesorregiões Noroeste, Centro Ocidental e Sudoeste. Foram encontrados alguns estudos focados na produção de soja do Rio Grande do Sul, sendo um uma caracterização do porto de Rio Grande e dois estudos da distribuição da produção no estado, por meio de econometria espacial (ROCHA; PARRÉ, 2009).

O Rio Grande do Sul é o único estado brasileiro onde os produtores de soja, além de contarem com o porto exportador dentro do próprio estado, também contam com os três tipos de modais (rodoviário, hidroviário e ferroviário) para o escoamento de sua produção. O transporte hidroviário é operado por várias empresas na Lagoa dos Patos (ANTAQ, 2011) e o ferroviário é operado pela RUMO ALL Malha Sul (RUMO ALL, 2015). Portanto, um estudo detalhado do Rio Grande do Sul pode trazer novas abordagens para logística no Brasil.

O porto de Rio Grande foi estabelecido como destino final de toda produção e foram encontradas 3 rotas exclusivamente rodoviárias, uma ferroviária, 9 combinações rodoviárias e hidroviárias, uma rota combinando os modais rodoviário e hidroviário, uma rota combinando os modais rodoviário e hidroviário e uma rota onde os três modais são utilizados, totalizando 16 rotas.

- $\quad$ Mato Grosso do Sul: Os dados da safra de 2013 (SIGA, 2014) e 2014 (SIGA, 2015), por município, foram retirados das circulares técnicas da Associação dos Produtores de Soja do Mato Grosso do Sul, APROSOJA-MS.

Não foram encontrados estudos de caracterização da logística de escoamento de commodities agrícolas no Mato Grosso do Sul. Usou-se como referência o relatório Centro Oeste Competitivo (MACROLOGÍSTICA, 2015) e os relatórios da AHRANA (AHRANA, 2005). Quando as informações eram divergentes prevaleceram as da AHRANA, por ser um órgão governamental e um relatório oficial. Foram determinadas seis rotas rodoviárias, uma ferroviária e duas combinações rodo e ferroviária, totalizando nove alternativas de escoamento.

- Goiás: Os dados foram retirados, por ano e por município, da homepage do Instituto Mauro Borges de Estatística e Estudos Socioeconômicos (GOIÁS, 2015).

Segundo a divisão geográfica do IBGE (IBGE, 2015), dois dos maiores municípios produtores estão na mesorregião Sul, macrorregião Sudeste. São elas: Jataí (5.732.615 t.) e Rio Verde (1.356.822 t.). Em seguida, o maior município produtor da 
safra estudada foi Cristalina (1.284.631 t.), na mesorregião Leste, microrregião do Encontro com o Distrito Federal.

As rotas foram estudadas tendo como origem esses municípios polos e destino os portos de Santos e Paranaguá. Os municípios de Jataí e Rio Verde escoam por ambos os portos, mas município o de Cristalina escoa apenas por Santos (MACROLOGÍSTICA, 2015; VIEIRA, 2002), talvez devido a sua localização.

Tendo como base o relatório Centro-Oeste Competitivo, conclui-se que todos os municípios escoam pelo modal rodoviário (chamados " $\mathrm{R}+$ algarismo") e elas desfrutam das mesmas opções de escoamento ("RHF+ algarismo" e "RHR+ algarismo"), por meio de São Simão (GO), que o estado de Mato Grosso. Além das rotas comuns com Mato Grosso, foi constatada a possibilidade de transporte rodoviário até Maringá (PR) e de lá por meio ferroviário, operado pela empresa RUMO ALL, Malha Sul (RUMO ALL, 2015).

Totalizando, Goiás conta com 16 rotas de escoamento dos três municípios que mais produziram até os principais portos, sendo 14 comuns com o estado de Mato Grosso. O presente modelo trata as rotas como totalmente independentes, mas será discutida a possibilidade de criação de um modelo que considere essa sobreposição de rotas.

O Quadro 3 compila o que foi discutido neste item, mostrando os estados brasileiros (em ordem decrescente de produção), as rotas consideradas (quantas são e qual sua característica modal) e seus portos exportadores de destino. 
Quadro 3 - Sumário das rotas no Brasil.

\begin{tabular}{|c|c|c|c|}
\hline Estado & Característica da Rota & \begin{tabular}{|c|} 
Quantidade \\
de \\
Rotas
\end{tabular} & Porto Destino \\
\hline \multirow{5}{*}{ Mato Grosso } & Rodoviário (R) & 6 & \multirow{5}{*}{ Santos e Paranaguá } \\
\hline & Rodo e Ferroviário (RF) & 6 & \\
\hline & Rodo, Hidro e Rodoviário (RHR)* & 6 & \\
\hline & Rodo, Hidro e Ferroviáio (RHF)* & 3 & \\
\hline & Total & 21 & \\
\hline \multirow{4}{*}{ Paraná } & Rodoviário $(\mathrm{R})$ & 6 & \multirow{4}{*}{ Santos e Paranaguá } \\
\hline & Ferroviário $(\mathrm{F})$ & 3 & \\
\hline & Rodo e Ferroviário (RF) & 1 & \\
\hline & Total & 10 & \\
\hline \multirow{7}{*}{ Rio Grande do Sul } & Rodoviário (R) & 3 & \multirow{7}{*}{ Rio Grande } \\
\hline & Ferroviário $(\mathrm{F})$ & 1 & \\
\hline & Rodo e Hidroviário (RH) & 9 & \\
\hline & Rodo e Ferroviário (RF) & 1 & \\
\hline & Ferro e Hidroviário $(\mathrm{FH})$ & 1 & \\
\hline & Rodo, Ferro e Hidroviário (RFH) & 1 & \\
\hline & Total & 16 & \\
\hline \multirow{4}{*}{ Mato Grosso do Sul } & Rodoviário (R) & 6 & \multirow{4}{*}{ Santos e Paranaguá } \\
\hline & Ferroviário $(\mathrm{F})$ & 1 & \\
\hline & Rodo e Ferroviário (RF) & 2 & \\
\hline & Total & 9 & \\
\hline \multirow{5}{*}{ Goiás } & Rodoviário (R) & 5 & \multirow{5}{*}{ Santos e Paranaguá } \\
\hline & Rodo e Ferroviário (RF) & 2 & \\
\hline & Rodo, Hidro e Rodoviário (RHR)* & 6 & \\
\hline & Rodo, Hidro e Ferroviáio (RHF)* & 3 & \\
\hline & Total & 16 & \\
\hline
\end{tabular}

\subsubsection{Contexto norte-americano}

Nos Estados Unidos, os maiores estados produtores de soja são: Iowa, Illinois, Minesota, Indiana, Nebraska e Missouri (SALIN, 2016). O Serviço Nacional de Estatística Agrícola (Nacional Agricultural Statistics Service) oferece relatórios com total de soja produzida, área plantada e área colhida por estado, por Distrito (subdivisão do estado), por município e por ano de safra. Esses relatórios são feitos separadamente por cada unidade federativa e submetidos ao Serviço Nacional. Por isso, há divergência de formatação e apresentação dos dados para cada estado.

Os relatórios foram consultados e os dados de interesse (produção de soja por município, por distrito e por estado para as safras de 2013 e 2014) foram extraídos para 
uma planilha em Excel. Para os estados norte-americanos foi adotado o mesmo procedimento dos estados brasileiros para determinação de rotas. Como primeiro passo para o cenário norte-americano, foram traçadas as distâncias para rotas rodoviárias, por meio do aplicativo Google Maps, entre as principais microrregiões produtoras e as principais eclusas estaduais. Foram obtidas as distâncias entre as eclusas estudadas e os destinos Baton Rouge (polo de processamento de soja) e Nova Orleans (porto exportador) com os dados da cartografia náutica de Distances Between United States Ports (NOAA, 2012). A Figura 24 indica as eclusas estudadas em vermelho e os portos de destino em azul.

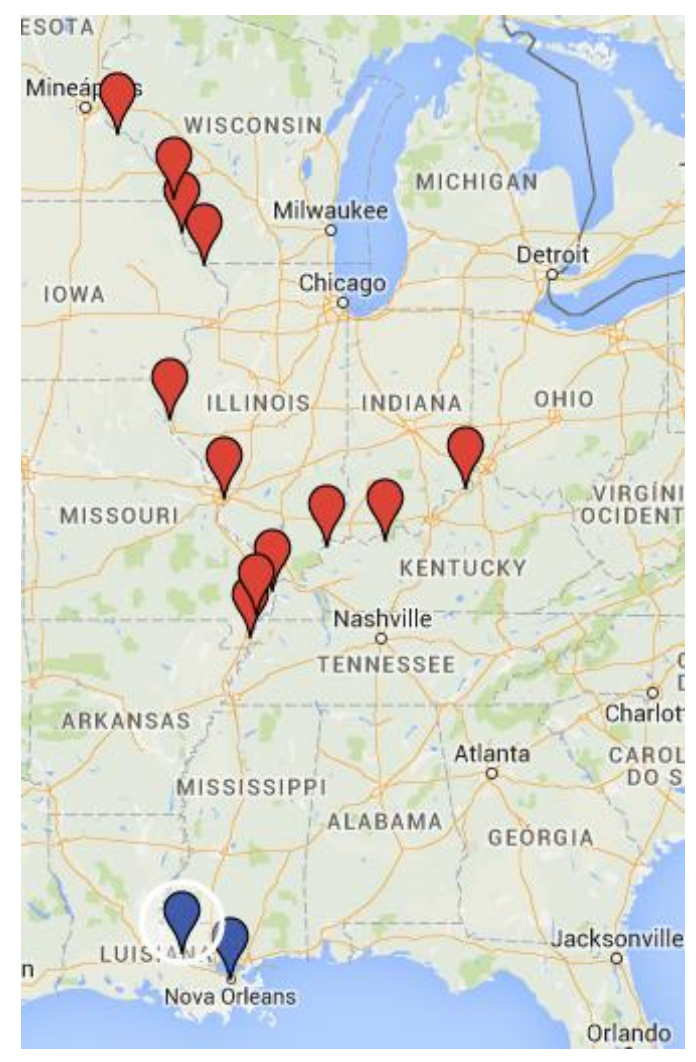

Figura 24 - Eclusas escolhidas para rotas de exportação estudadas.

Em média, da lavoura até o porto, a soja percorre 129,3 km por via rodoviária e $884,2 \mathrm{~km}$ por hidroviário. A rota mais longa, da cidade de Lac qui Parle, Minesota, até Nova Orleans, percorre $121,8 \mathrm{~km}$ por rodovias e $1.253,5 \mathrm{~km}$ por hidrovias. A rota mais curta, de New Madri, Missouri, até Nova Orleans, percorre 21,2 km por rodovias e $569,1 \mathrm{~km}$ por hidrovias.

Comparando-se as informações de carga para cada eclusa e sua posição com a dos principais portos, não foi observada nenhuma diferença significativa. Portanto, este 
trabalho considerou, exceto quando especificado em contrário, a distância entre os principais produtores e os principais portos.

Para o sistema ferroviário, foi escolhido como destino preferencial o Port of Gray Harbors (estado de Washington) por ser um porto histórico e líder na exportação de carne de soja (PORT OF GRAYS HARBOUR, 2016). A extensão das rotas ferroviárias foi feita, considerando-se os terminais intermodais mais próximos das empresas operantes, no caso, majoritariamente BNSF e Union Pacific. Assumiu-se que a rota de Chicago a Portland do trem turístico Empire Builder (AMTRAK, 2010) possui distância igual $(3.632 \mathrm{~km})$ à da rota da BNSF de Chicago a Portland. Assumida essa hipótese, as demais distâncias foram calculadas por proporcionalidade.

Seguindo a mesma lógica adotada para os estados brasileiros, segue-se uma breve descrição das rotas adotadas no modelo para os estados norte-americano, seguindo uma ordem decrescente de tamanho de safra:

- Iowa: No relatório (IOWA, 2014) é possível encontrar os dados de 2013 e 2014, além de uma breve análise comparativa entre os dois anos e um mapa da densidade produtiva por sub-região. De acordo com este mesmo documento, em 2014, os municípios que mais produziram foram Plymouth, Pottawattamie, Kossuth e Sioux. E a produção de soja de Iowa foi a terceira maior da História, apenas inferior à dos anos de 2005 e 2006.

Para a determinação dos corredores ferroviários, foi verificado nos mapas ferroviários das empresas Union Pacific e BNSF (BNSF, 2016) que o terminal intermodal mais próximo das três maiores regiões microprodutoras de Iowa (Plymonth, Woodbury, Webster) é o terminal de Cedar Rapids. Foi determinada a rota rodoviária mais curta, por meio do Google Maps. Essas rotas totais (distâncias rodo e ferroviária) foram denominadas "ERF+número identificador", sendo "E" referente a Estados Unidos, "RF" referente à combinação de modais rodoviário e ferroviário. Assim, três rotas foram consideradas.

As maiores cidades produtoras de soja no estado de Iowa encontram-se na extremidade oeste do estado, distante da hidrovia do Rio Mississipi. Porém, este rio é a única alternativa hidroviária possível.

A rota que parte da principal microrregião produtora Plymonth está mais próxima da eclusa de Prairie du Chien. As rotas que partem das outras duas microrregiões (Woodbury, Webster) estão mais próximas da eclusa de Dubuque. Elas foram chamadas de "ERH + número", sendo "E" referente a Estados Unidos e "RH" 
referente ao envolvimento de dois modais, o rodo e o hidroviário. Três rotas foram consideradas.

- Illinois: O relatório só mostra os dados de uma safra por município e por sub-região, sem informações adicionais. Foram extraídos dados de dois relatórios, Illinois (2014) e Illinois (2015).

Para a determinação dos corredores ferroviários, foi verificado que o terminal intermodal mais próximo das três maiores regiões microprodutoras é o terminal de Hodgkins. Foram determinadas três. Essas rotas foram denominadas "ERF+número identificador", sendo "E" referente a Estados Unidos, "RF" referente à combinação de modais rodoviário e ferroviário.

Devido a esse fato, o presente trabalho considerou rotas entre as principais cidades produtoras de soja até o Porto de Saint Louis, por sua importância econômica, e até as cidades de Quincy e Cairo. A primeira representando a eclusa economicamente relevante mais próxima e a segunda, a economicamente relevante mais distante.

As rotas que partem das principais microrregiões produtoras de Illinois (Edgar, Champain e Mclean) estão mais próximas da eclusa de Saint Louis. Elas foram chamadas de "ERH + número", sendo "E" referente a Estados Unidos e "RH" referente ao envolvimento de dois modais, o rodo e o hidroviário. Três rotas foram consideradas.

- Minesota: O relatório (MINESOTA, 2014) possui informações tão pormenorizadas quanto o de Iowa para as safras de 2013 e 2014. O relatório informa que, em 2014, os maiores municípios produtores foram Polk, Redwood, Renville e Lac Qui Parle, e que, neste ano, o estado teve a quinta maior produção de sua História.

Para a determinação dos corredores ferroviários, foi verificado nos mapas ferroviários da empresa BNSF (BNSF, 2016) que o terminal intermodal mais próximo das três maiores regiões microprodutoras de Minesota (Lac qui Parle, Cottonwood, Ferribault) é o terminal de Willmar para as duas primeiras e o de Minneapolis para a terceira. Essas rotas foram denominadas "ERF+número identificador", sendo "E" referente a Estados Unidos, "RF" referente à combinação de modais rodoviário e ferroviário.

As rotas que partem das três microrregiões que mais produziram em Minesota (Lac qui Parle, Cottonwood, Faribault) estão mais próximas da eclusa de Red Wing. Elas foram chamadas de "ERH + número", sendo "E" referente a Estados Unidos e "RH" referente ao envolvimento de dois modais, o rodo e o hidroviário. Três rotas foram consideradas. 
- Indiana: O relatório só mostra os dados de uma safra por município e por sub-região, sem informações adicionais. Foram extraídos dados de dois relatórios, Indiana (2014) e Indiana (2015).

Para a determinação dos corredores ferroviários, foi verificado nos mapas ferroviários da empresa BNSF (BNSF, 2016) que o terminal intermodal mais próximo das três maiores regiões microprodutoras de Indiana (Knox, Clinton, Montgomery) é o terminal de Chicago. Foram determinadas três rotas (diferentes apenas no modal rodoviário que levam até este terminal e de lá seguem pelo modal ferroviário). Essas rotas foram denominadas "ERF+número identificador", sendo "E" referente a Estados Unidos, "RF" referente à combinação de modais rodoviário e ferroviário.

As eclusas e represas de Indiana apresentam uma intensidade de uso muito similar em qualquer altura do rio. O presente estudo escolheu avaliar o trajeto dos maiores produtores até a primeira, a terceira e a última eclusa, pois isso é suficiente para correta representação das rotas territoriais no estado de Indiana.

A rota que parte da principal microrreigião produtora Knox está mais próxima da eclusa de Markland, as rotas que partem das outras duas microrregiões (Clinton, Montgomery) estão mais próximas da eclusa de Cannelton. Elas foram chamadas de "ERH + número", sendo "E" referente a Estados Unidos e "RH" referente ao envolvimento de dois modais, o rodo e o hidroviário. Três rotas foram consideradas.

- Nebraska: Não foi encontrado um relatório para este estado. Apenas informações muito condensadas, chamada pelo site de QuickStats (Estáticas Rápidas, tradução livre). Esses dados foram julgados insuficientes para o presente estudo. Por isso, decidiu-se excluir Nebraska e incluir o sexto maior estado produtor, Missouri.

- Missouri: O relatório só mostra os dados de uma safra por município e por sub-região, sem informações adicionais. Foram extraídos dados de dois relatórios, Missouri (2014) e Missouri (2015).

Para a determinação dos corredores ferroviários, foi verificado nos mapas ferroviários da empresa BNSF (BNSF, 2016) que o terminal intermodal mais próximo das três maiores regiões microprodutoras de Missouri (Nodaway, Audrain, New Madrid) é o terminal de Kansas City para as duas primeiras e o de Memphis para a terceira. Essas rotas foram denominadas "ERF+número identificador", sendo "E" referente a Estados Unidos, "RF" referente à combinação de modais rodoviário e ferroviário. 
As rotas que partem das três microrregiões que mais produziram em Missouri (Nodaway, Audrain, New Madrid) estão mais próximas da eclusa de Saint Louis, exceto New Madrid que conta com o privilégio de ter uma eclusa próxima. Elas foram chamadas de "ERH + número", sendo "E" referente a Estados Unidos e "RH" referente ao envolvimento de dois modais, o rodo e o hidroviário. Três rotas foram consideradas. New Madrid foi considerada $\mathrm{EH}$, ou seja, a única rota com modal único (hidroviário).

O Quadro 4 compila o que foi discutido neste item, mostrando os estados (em ordem decrescente de produção), as rotas consideradas (quantas são e qual sua característica modal) e seus portos exportadores de destino.

Quadro 4 - Sumário das rotas nos EUA.

\begin{tabular}{|c|c|c|c|}
\hline Estado & Característica da Rota & $\begin{array}{c}\text { Quantidade } \\
\text { de } \\
\text { Rotas } \\
\end{array}$ & Porto Destino \\
\hline \multirow{3}{*}{ Iowa } & Rodo e Hidroviário (ERH)* & 3 & \multirow{3}{*}{ Nova Orleans e NPW } \\
\hline & $\begin{array}{l}\text { Rodo e F } \\
\text { viário (ERF)* }\end{array}$ & 3 & \\
\hline & Total & 6 & \\
\hline \multirow{3}{*}{ Illinois } & Rodo e Hidroviário (ERH)* & 3 & \multirow{3}{*}{ Nova Orleans e NPW } \\
\hline & Rodo e Ferroviário (ERF)* & 3 & \\
\hline & Total & 6 & \\
\hline \multirow{3}{*}{ Indiana } & Rodo e Hidroviário (ERH)* & 3 & \multirow{3}{*}{ Nova Orleans e NPW } \\
\hline & Rodo e Ferroviário (ERF)* & 3 & \\
\hline & Total & 6 & \\
\hline \multirow{3}{*}{ Minnesota } & Rodo e Hidroviário (ERH)* & 3 & \multirow{3}{*}{ Nova Orleans e NPW } \\
\hline & Rodo e Ferroviário (ERF)* & 3 & \\
\hline & Total & 6 & \\
\hline \multirow{3}{*}{ Missouri } & Rodo e Hidroviário (ERH)* & 3 & \multirow{3}{*}{ Nova Orleans e NPW } \\
\hline & Rodo e Ferroviário (ERF)* & 3 & \\
\hline & Total & 6 & \\
\hline
\end{tabular}

\subsubsection{Sobre a Análise dos Dados}

Conforme discutido no tópico 2.3.1 Limitações da DEA, é fundamental entender o comportamento das variáveis DEA por meio de análises estatística e/ou escolher as variáveis por meio de embasamento na literatura especializada. No caso proposto, a literatura é escassa, impossibilitando uma escolha de variáveis baseada nela. 
A Figura 25 mostra a relação entre as variáveis do modelo. Presume-se que a área plantada (independente) afeta diretamente a quantidade de soja transportada (dependente), assim como o consumo de combustível (independente) afeta a quantidade de emissões (dependente). As variáveis armazéns (internos e externos), consumo de combustivel, fator de descarte e fatalidades podem possuir alguma relação com (ou seja, serem dependentes de) quantidade de soja transportada (independente). Assim como consumo de combustível, fator de descarte e fatalidade (dependentes) podem ter uma relação com a extensão da rota (independente).

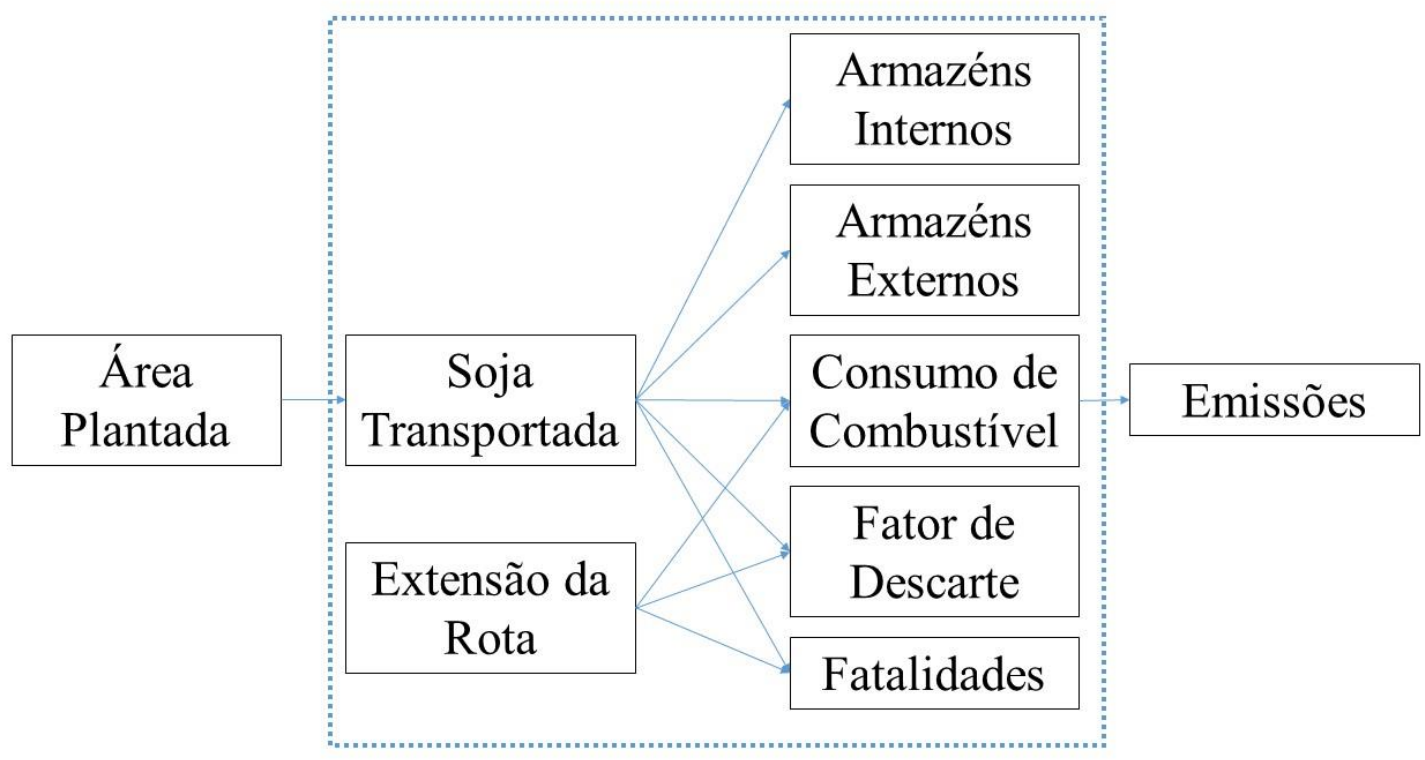

Figura 25 - Provável relação de dependência (causa e efeito) entre as variáveis.

A Análise de componentes principais (PCA) é uma técnica multivariada que analisa uma tabela de dados cujas observações são descritas por algumas variáveis dependentes e intercorrelacionadas. O objetivo é extrair informações importantes da tabela de dados, para representar um conjunto de novas variáveis ortogonais, chamadas de componentes principais (ABDI e WILLIAMS, 2010). Já foi inclusive desenvolvido um método integrado de DEA BCC e PCA para a exclusão de variáveis (ADLER e YAZHEMSKY, 2010). Como o presente trabalho aplica o modelo SBM, optou-se por analisar as variáveis por meio da PCA (no software STATA) antes da aplicação do DEA SBM. E, não, de maneira integrada.

De acordo do Abdi e Williams (2010), os objetivos da PCA são:

(1) Extrair as informações mais importantes de uma tabela de dados; 
(2) Comprimir o tamanho do conjunto de dados mantendo apenas as informações importantes;

(3) Simplificar a descrição do conjunto de dados;

(4) Analisar a estrutura das observações e suas variáveis.

Para analisar a PCA, os softwares reprocessam os dados antes da análise. Esse reprocessamento pode se dar de uma das duas seguintes formas:

(1) As colunas da matriz são centralizadas de modo que a média de cada coluna seja igual a 0 . Em seguida, cada elemento da coluna é dividido pelo desvio padrão. Neste caso, o processo é chamada PCA de convariância.

(2) Quando as variáveis tem diferentes unidades de medida (como é o caso da maioria das aplicações de DEA), a padronização das colunas é feita por um processo de normalização. Neste caso, o processo é chamada de PCA de correlação(ABDI ;WILLIAMS, 2010). Este é o default da PCA dos software STATA.

O primeiro passo da análise foi gerar a matriz de correlação por meio dos seguintes comandos: Statistics > Summaries, Tables and Tests > Summary and Descriptive Statistics > Correation and Covariances. O resultado esta apresentado na Tabela 7. Evans (1996) classifica a força da associação entre as variáveis da seguinte maneira: de 0 a 0,2, muito fraca; de 0,2 a 0,4, fraca; de 0,4 a 0,6 moderada; de 0,6 a 0,8 forte; e de 0,8 a 1 , muito forte.

A escolha de variáveis é um desafio nas aplicações de DEA (COOK, TONE; ZHU, 2014). Golany e Roll (1989) propuseram um método em três passos para escolha de um modelo apropriado de DEA e variáveis. Os passos são os seguintes: (i) julgamento do cenário como um todo; (ii) métodos quantitativos; (iii) análise baseada na própria DEA, i.e., tentativa e erro. Para o primeiro passo, os autores, assim como Cook, Tone e Zhu (2014) enfatizam a importância da visão de um especialista que entenda todo o processo. Um forte embasamento na literatura, também reforça essa visão. No segundo passo, os autores sugerem o uso de regressões lineares para definição do que seria input e o que seria output. Uma relação fraca de uma variável com demais inputs e forte com outputs, indica uma preferência em classifica-la como input. Ao contrário, uma relação forte entre inputs e fraca com outputs, tende a fazer a variável ser classificada como output. Uma relação fraca com todas as variáveis (ou, paralelamente, forte com todas as variáveis) pode indicar a exclusão da mesma. Mais tarde, os mesmo autor principal passou a atualizar a PCA como uma alternativa (ADLER; GOLANY, 
2001). A Tabela 7 também classifica a força de associação entre as variáveis, de acordo com Evans (1996). 
Tabela 7 Análise da matriz de correção das variáveis.

\begin{tabular}{|c|c|c|c|c|c|c|c|c|c|}
\hline & $\begin{array}{l}\text { Consumo de } \\
\text { Combustível } \\
\end{array}$ & $\begin{array}{l}\text { Área } \\
\text { Plantada }\end{array}$ & $\begin{array}{l}\text { Fator de } \\
\text { Descarte } \\
\end{array}$ & $\begin{array}{l}\text { Emissõe } \\
\mathbf{S}\end{array}$ & $\begin{array}{l}\text { Fatalida } \\
\text { des }\end{array}$ & $\begin{array}{l}\text { Soja } \\
\text { Transportada }\end{array}$ & $\begin{array}{l}\text { Armazéns } \\
\text { Internos } \\
\end{array}$ & $\begin{array}{l}\text { Armazéns } \\
\text { Externos } \\
\end{array}$ & $\begin{array}{l}\text { Extensão da } \\
\text { Rota }\end{array}$ \\
\hline $\begin{array}{l}\text { Consumo de } \\
\text { Combustivel }\end{array}$ & 1 & & & & & & & & \\
\hline Área Plantada & 0,3884 & 1 & & & & & & & \\
\hline Fator de Descarte & 0,7311 & 0,5954 & 1 & & & & & & \\
\hline Emissões & 0,9274 & 0,3834 & 0,5997 & 1 & & & & & \\
\hline Fatalidades & 0,4995 & 0,3537 & 0,1304 & 0,6518 & 1 & & & & \\
\hline Soja Transportada & 0,2303 & 0,9147 & 0,4503 & 0,2211 & 0,2750 & 1 & & & \\
\hline $\begin{array}{l}\text { Armazéns Internos } \\
\text { Armazéns }\end{array}$ & $-0,0375$ & $-0,2924$ & $-0,2495$ & $-0,1665$ & $-0,2721$ & $-0,2123$ & 1 & & \\
\hline Externos & 0,1296 & 0,2504 & 0,0811 & 0,0701 & $-0,1555$ & 0,2333 & 0,4712 & 1 & \\
\hline Extensão da Rota & 0,1987 & $-0,1529$ & $-0,1344$ & $-0,0023$ & 0,1148 & $-0,1094$ & 0,5531 & 0,0929 & 1 \\
\hline & $\begin{array}{l}\text { Consumo de } \\
\text { Combustível } \\
\end{array}$ & $\begin{array}{l}\text { Área } \\
\text { Plantada }\end{array}$ & $\begin{array}{l}\text { Fator de } \\
\text { Descarte }\end{array}$ & $\begin{array}{l}\text { Emissõe } \\
\text { s }\end{array}$ & $\begin{array}{l}\text { Fatalida } \\
\text { des }\end{array}$ & $\begin{array}{l}\text { Soja } \\
\text { Transportada }\end{array}$ & $\begin{array}{l}\text { Armazéns } \\
\text { Internos }\end{array}$ & $\begin{array}{l}\text { Armazéns } \\
\text { Externos }\end{array}$ & $\begin{array}{l}\text { Extensão da } \\
\text { Rota }\end{array}$ \\
\hline $\begin{array}{l}\text { Consumo de } \\
\text { Combustivel }\end{array}$ & 1 & & & & & & & & \\
\hline Área Plantada & Fraca & 1 & & & & & & & \\
\hline Fator de Descarte & Forte & Moderada & 1 & & & & & & \\
\hline Emissões & Muito Forte & Fraca & Moderada & 1 & & & & & \\
\hline Fatalidades & Moderada & $\begin{array}{l}\text { Fraca } \\
\text { Muito }\end{array}$ & Muito Fraca & Forte & 1 & & & & \\
\hline Soja Transportada & Fraca & Forte & Moderada & $\begin{array}{l}\text { Fraca } \\
\text { Muito }\end{array}$ & Fraca & 1 & & & \\
\hline $\begin{array}{l}\text { Armazéns Internos } \\
\text { Armazéns }\end{array}$ & Muito Fraca & Fraca & Fraca & $\begin{array}{l}\text { Fraca } \\
\text { Muito }\end{array}$ & $\begin{array}{l}\text { Fraca } \\
\text { Muito }\end{array}$ & Fraca & 1 & & \\
\hline Externos & Muito Fraca & $\begin{array}{l}\text { Fraca } \\
\text { Muito }\end{array}$ & Muito Fraca & $\begin{array}{l}\text { Fraca } \\
\text { Muito }\end{array}$ & $\begin{array}{l}\text { Fraca } \\
\text { Muito }\end{array}$ & Fraca & Moderada & 1 & \\
\hline Extensão da Rota & Muito Fraca & Fraca & Muito Fraca & Fraca & Fraca & Muito Fraca & Moderada & Muito Fraca & 1 \\
\hline
\end{tabular}


Observa-se que armazéns internos apresenta correlação negativa e fraca ou moderadamente fraca com todas as demais variáveis. Armazéns externos apresenta uma correlação fraca ou muito fraca com praticamente todas as variáveis. Exceto com armazéns internos, com a qual a correlação é moderada. Isso poderia sugerir a exclusão dessas variáveis. Mas optou-se por mantê-las pelas razões discutidas no tópico 3.3.3. Extensão da rota também apresentou uma relação fraca ou muito fraca com as demais variáveis, exceto armazéns internos.

Consumo de combustível (input) apresenta uma correlação fraca com área planta (input) e forte ou moderadamente forte com três dos quatro ouputs (fator de descarte, emissões e fatalidades). Área planta (input) apresenta uma correlação muito forte com soja transportada (output) e moderada com fator de descarte (output). Para os demais outputs a correlação é fraca. Fator de descarte (output) apresenta o comportamento próximo ao ideal desejado, ou seja, sendo u output, apresenta uma correlação forte ou moderada com os demais os inputs e fraca ou moderada com os outputs. Já fatalidades apresenta um comportamento longe do ideal desejado, apresentando uma correlação fraca com inputs e forte com outputs. Emissões apresente uma relação forte com um input (consumo de combustível) e uma relação também forte com o output fatalidades. A análise da matriz de correlação sugere atenção especial às variáveis extensão da rota, emissões e fatalidades, uma vez que, parte-se do pressuposto que as variáveis ligadas à capacidade de armazenamento não serão excluídas.

O modelo de PCA adota é o fixo. Ou seja, a PCA está sendo usado para análise de variáveis deste conjunto em questão e seus resultados não podem ser extrapolados para uma população mais ampla. A Tabela 8 mostra os resultados da PCA.

A importância da componente é refletiva pela inércia ou pelo total de inércia explicada pelo fator. Na Tabela 8 pode-se notar que o total de inércia da primeira componente corresponde a $40, \%$ do total, da segunda, $20,32 \%$, da terceira, $17,20 \%$ e assim sucessivamente, conforme mostrado na coluna Proporção. Dessa forma, observa-se que na PCA a ordem das componentes importa, sendo as primeiras componentes decrescentemente mais representativas para o modelo. $\mathrm{O}$ valor acumulado dessa inércia é apresentado na coluna Cumulativo e representa o percentual do modelo “explicado" pela soma das componentes. 
Tabela 8 Resultado da análise de componentes principais (PCA).

\begin{tabular}{lrrrc}
\hline Componente & Autovalor & Diferença & Proporção & Cumulativo \\
\hline Comp. 1 & 3,60023 & 1,77101 & 0,4000 & 0,4000 \\
Comp. 2 & 1,82922 & 0,280941 & 0,2032 & 0,6033 \\
Comp. 3 & 1,54828 & 0,605416 & 0,1720 & 0,7753 \\
Comp. 4 & 0,94286 & 0,289203 & 0,1048 & 0,8801 \\
Comp. 5 & 0,653657 & 0,408689 & 0,0726 & 0,9527 \\
Comp. 6 & 0,244967 & 0,136975 & 0,0272 & 0,9799 \\
Comp. 7 & 0,107992 & 0,0501612 & 0,0120 & 0,9919 \\
Comp. 8 & 0,0578309 & 0,0428571 & 0,0064 & 0,9983 \\
Comp. 9 & 0,0149737 & - & 0,0017 & 1,0000 \\
\hline
\end{tabular}

Componentes Principais (autovetores)

\begin{tabular}{|c|c|c|c|c|c|c|c|c|c|c|}
\hline Variável & Comp. 1 & Comp. 2 & Comp. 3 & Comp. 4 & Comp. 5 & Comp. 6 & Comp. 7 & Comp. 8 & Comp. 9 & Inexplicado \\
\hline Consumo de Combustivel & 0,4317 & 0,2822 & $-0,2634$ & $-0,2484$ & 0,0609 & $-0,0447$ & $-0,2528$ & 0,0304 & $-0,7296$ & 0 \\
\hline Área Plantada & 0,4227 & $-0,1016$ & 0,3979 & 0,2364 & 0,095 & 0,0272 & 0,0443 & $-0,763$ & $-0,0543$ & 0 \\
\hline Emissões & 0,437 & 0,1604 & $-0,3255$ & $-0,1694$ & $-0,2607$ & 0,1294 & $-0,4271$ & $-0,0975$ & 0,61 & 0 \\
\hline Fator de Descarte & 0,4186 & $-0,0006$ & 0,0658 & $-0,4625$ & 0,4323 & $-0,0023$ & 0,5752 & 0,194 & 0,226 & 0 \\
\hline Fatalidades & 0,3214 & 0,0147 & $-0,369$ & 0,5485 & $-0,3933$ & 0,0643 & 0,5248 & 0,1425 & $-0,0703$ & 0 \\
\hline Soja Transportada & 0,3535 & $-0,1042$ & 0,4741 & 0,3657 & 0,1512 & 0,2047 & $-0,3293$ & 0,5765 & 0,0114 & 0 \\
\hline Armazéns Internos & $-0,1836$ & 0,6222 & 0,1576 & $-0,0124$ & $-0,0042$ & 0,7268 & 0,1435 & $-0,0712$ & $-0,0182$ & 0 \\
\hline Armazéns Externos & 0,0645 & 0,4115 & 0,5042 & $-0,1816$ & $-0,5478$ & $-0,4628$ & 0,1135 & 0,1077 & 0,0249 & 0 \\
\hline Extensão da Rota & $-0,0514$ & 0,5629 & $-0,1487$ & 0,4148 & 0,5047 & $-0,4384$ & $-0,0593$ & $-0,0221$ & 0,1884 & 0 \\
\hline
\end{tabular}


Para se determinar quantas componentes serão mantidas, existem duas tradições: (i) colocar todos os coeficientes de cada componente para uma determinada variável em um gráfico e observar se existe uma transição de uma curva acentuada para uma linha mais plana. As componentes antes dessa transição devem ser mantidas. Isso é chamado o teste do cotovelo e possui um teor subjetivo; ou (ii) para a PCA de correlação, manter apenas as componentes cujo autovalor está acima de 1 e para a PCA de variância, manter as componentes cujo autovalor está acima da média (ABDI e WILLIAMS, 2010).

Como pode ser visto na Tabela 8, as componentes 1, 2 e 3 possuem autovalores acima de 1, respectivamente, 3,60023, 1,82922 e 1,54828. Outra heurística útil é interpretar, dentro de cada componente, quais variáveis contribuem acima da média na estrutura da componente. Nota-se são considerados os valores em módulo para esta análise, pois o sinal indica apenas direção da relação. A Tabela 9 mostra quais variáveis têm coeficientes abaixo da média de coeficientes de cada componente.

Tabela 9 Análise dos coeficientes que compõem as três primeiras componentes.

\begin{tabular}{lcccc}
\hline Variável & Comp.1 & Comp.2 & Comp.3 & Freq. Verdadeiro \\
\hline Consumo de Combustivel & & & FALSO & 2 \\
Área Plantada & & FALSO & & 2 \\
Emissões & & FALSO & & 2 \\
Fator de Descarte & & FALSO & FALSO & 1 \\
Fatalidades & & FALSO & & 2 \\
Soja Transportada & & FALSO & & 2 \\
Armazéns Internos & FALSO & & FALSO & 2 \\
Armazéns Externos & FALSO & & & 2 \\
Extensão da Rota & FALSO & & FALSO & 1 \\
\hline
\end{tabular}

É importante notar que na PCA, a ordem das componentes importa. Portanto, o fato de que, pela Tabela 9, na componente 1, os coeficientes as variáveis armazéns internos, armazéns externos e extensão da rota se mostrarem abaixo da média é um indicativo de que essas variáveis poderiam ser excluídas. Na segunda componente, a variável consumo de combustível continua acima da média, reforçando a importância dessa variável. Apenas duas variáveis se mostraram abaixo da média em duas das três componentes. No caso, a variável fator de descarte está abaixo da média nas componentes 2 e 3 e a variável extensão da rota nas componentes 1 e 3 . Isso sugere a 
exclusão dessas variáveis, com maior ênfase para a variável extensão da rota, porque ela se encontra abaixo da média na primeira componente.

Para avaliar a qualidade da reconstituição da matriz original por suas componentes principais em modelos de efeito fixo, avalia-se a similaridade entre as duas matrizes (a original e a gerada pelas componentes principais). Vários coeficientes podem ser usados para esta comparação, o mais popular é a soma dos resíduos ao quadrado (representado pela sigla RESS em inglês). Quando menor o valor de RESS, melhor é o modelo de PCA. O RESS foi calculado no software Excel, seu resultado foi $3,246 \mathrm{e}^{-06}$, portanto, considerado satisfatório.

Em continuidade à análise dos dados, decidiu-se realizar uma investigação de homogeneidade dos dados do modelo. Para isso, utilizou-se o teste de Wilcoxon para amostras independentes, um teste não-paramétrico proposto para essa análise em DEA por Hua e He (2006). As possíveis causas de heterogeneidade seriam: as amostras são heterogêneas porque elas são de países diferentes; as amostras são heterogêneas porque as rotas englobam modais diferentes. Para testar a heterogeneidade entre países foi feito o teste de Wilcoxon entre Brasil e EUA. Os resultados estão na Tabela 10.

Tabela 10 Resultado do Teste de Wilcoxon entre Brasil e EUA.

\begin{tabular}{|cc|}
\hline \multicolumn{2}{|c|}{ Tabela da Estatística do Teste (Wilcoxon) } \\
Informações & Valores \\
\hline Estatística & 85250,5 \\
P-valor & 0,5426 \\
Hipótese Nula & 0 \\
Limite Inferior & $-1166,29063$ \\
(Pseudo) Mediana & $-121,7196474$ \\
Limite Superior & 551,0699922 \\
Nível de Confiança & 0,95 \\
\hline
\end{tabular}

Como se pode ver na Tabela 10, a hipótese nula não foi rejeitada $(0,5426)$, indicando que as amostras podem ser homogêneas e a DEA pode ser aplicada. Para testar a heterogeneidade entre rotas com diferentes modais foi feito teste de Wilcoxon entre rotas unimodais e bimodais (Tabela 11), entre unimodais e trimodais (Tabela 12) e entre bimodais e trimodais (Tabela 13). 
Tabela 11 Resultado de Wilcoxon entre rotas com um único modal e rotas com dois modais.

\begin{tabular}{|cc|}
\hline \multicolumn{2}{|c|}{ Tabela da Estatística do Teste (Wilcoxon) } \\
Informações & Valores \\
\hline Estatística & 65577,5 \\
P-valor & 0,8568 \\
Hipótese Nula & 0 \\
Limite Inferior & $-900,9800389$ \\
(Pseudo) Mediana & $-0,289987882$ \\
Limite Superior & 746,2300183 \\
Nível de Confiança & 0,95 \\
\hline
\end{tabular}

A Tabela 11 mostra que a hipótese nula não foi rejeitada na comparação entre rotas de um modal único e rotas de dois modais $(0,8568)$, isto é, as amostras tendem a ser homogêneas, permitindo-se a aplicação de DEA.

Tabela 12 Resultado de Wilcoxon entre rotas com um único modal e rotas com três modais.

\begin{tabular}{|cc|}
\hline \multicolumn{2}{|c|}{ Tabela da Estatística do Teste (Wilcoxon) } \\
Informações & Valores \\
\hline Estatística & 24364 \\
P-valor & 0,8502 \\
Hipótese Nula & 0 \\
Limite Inferior & $-1565,999959$ \\
(Pseudo) Mediana & $-1,004996399$ \\
Limite Superior & 1401,999957 \\
Nível de Confiança & 0,95 \\
\hline
\end{tabular}

A Tabela 12 mostra que a hipótese nula para a comparação de rotas com um e três modais também não foi rejeitada $(0,8502)$. As amostras tendem a ser homogêneas e a DEA pode ser aplicada.

Tabela 13 Resultado de Wilcoxon entre rotas com dois e três modais.

\begin{tabular}{|cc|}
\hline \multicolumn{2}{|c|}{ Tabela da Estatística do Teste (Wilcoxon) } \\
Informações & Valores \\
\hline Estatística & 38822,5 \\
P-valor & 0,8356 \\
Hipótese Nula & 0 \\
Limite Inferior & $-1407,110032$ \\
(Pseudo) Mediana & $-2,379940222$ \\
Limite Superior & 992,7600353 \\
Nível de Confiança & 0,95 \\
\hline
\end{tabular}


A Tabela 13 mostra que a hipótese nula para a comparação de rotas com dois e três modais também não foi rejeitada $(0,8356)$. As amostras tendem a ser homogêneas e a DEA pode ser aplicada.

Dessa forma, entende-se que a maior divergência entre as rotas é devido ao país analisado, as rotas brasileiras apresentam um desempenho diferente das rotas norteamericanas. No entanto, essas divergências não significativas ao ponto de se afirmar que as amostras são heterogêneas e a DEA não pode ser aplicada.

\subsubsection{Sobre o Modelo}

A partir dos resultados parciais, optou-se por excluir a variável fatalidades. Coincidentemente, Panagakos (2016) também se viu obrigado a excluir suas variáveis do pilar social. Segundo o autor, elas são de pouco interesse para os integrantes da cadeia. Dessa forma, o modelo seguiu como expressado pela Figura 26.

Inicialmente, optou-se pelas variáveis de entrada (ou inputs): consumo de combustivel e área plantada. A extensão da rota é uma variável não controlável. São variáveis de saída (ou outputs): capacidade estática de armazenamento dentro das fazendas (também chamada armazéns internos) e a capacidade estática de armazenamento fora das fazendas (também chamada de armazéns externos) e a soja transportada. Optou-se por manter esses dois tipos de armazenamento porque o resultado DEA pode indicar qual tipo é mais eficiente (ou mais deficitário) e direcionar as políticas de investimento em armazéns. São variáveis de saída indesejadas (ou outputs indesejáveis): emissões e fator de descarte. Essas variáveis foram inseridas como inputs para serem minimizadas pelo modelo. Essa configuração de variáveis foi chamada de Cenário A. 


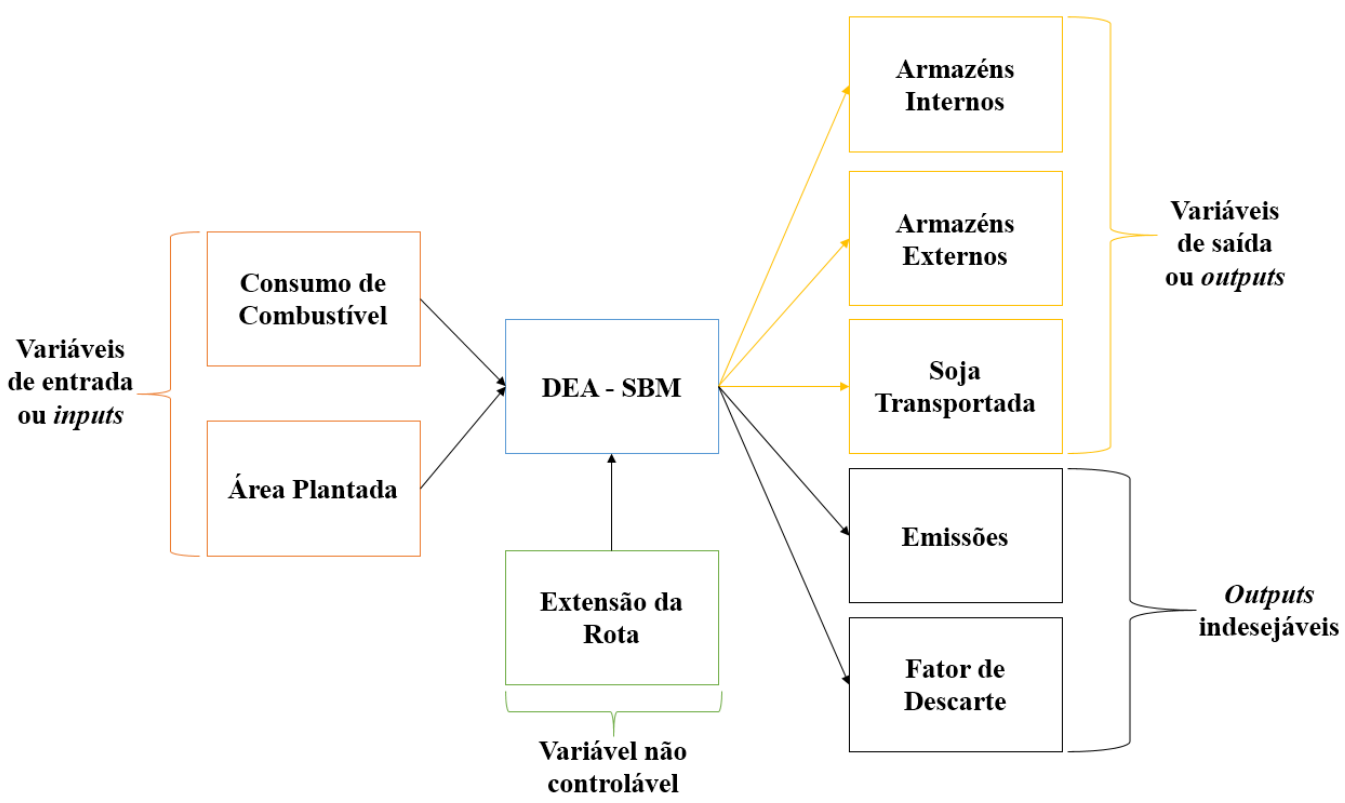

Figura 26 - Modelo proposto (Cenário A).

Para continuar a investigação, optou-se por outros cenários, um cenário com a variável extensão da rota como input controlável (Cenário B). Um cenário onde a variável extensão da rota é excluída e desconsiderada (Cenário C). Todos os modelos foram rodados com uso do software MatLab. 


\subsection{Resultados finais}

Os resultados para os cenários A, B e C estão integralmente no Apêndice B (respectivamente Tabela 18, Tabela 19, Tabela 20). O cenário A teve 32 empates de eficiência máxima $(1,00)$, número maior do que os empates encontrados no cenário $\mathrm{B}$ (28) e no cenário $\mathrm{C}(18)$. Portanto, para todos foi aplicada a técnica quantitativa de desempate do índice composto para a construção do ranking. Foi observada semelhança entre os resultados para os três cenários.

A Tabela 14 mostra a compilação das características das dez rotas mais e menos eficientes para os três cenários. Observa-se que, para os três cenários, não houve nenhuma rota com um modal único entre as eficientes, por outro lado, houve de três a quatro entre as ineficientes (dependendo do cenário). Em todos os cenários, não houve rotas norte-americanas entre as ineficientes. Isso poderia ser explicado devido ao fato de que a quantidade de rotas norte-americanas é bem menor (30 norte americanas e 72 brasileiras), porém, ao observar as rotas mais eficientes, nota-se que ainda prevaleceram as rotas norte-americanas (de seis a oito dependendo do cenário).

Tabela 14 Compilação das características das dez rotas mais e menos eficientes.

\begin{tabular}{lcccccc}
\hline & \multicolumn{5}{c}{ Dez mais eficientes } & \multicolumn{5}{c}{ Dez menos eficientes } \\
\cline { 2 - 7 } & Cenário A & Cenário B & Cenário C & Cenário A & Cenário B & Cenário C \\
\hline Unimodal & 0 & 0 & 0 & 4 & 3 & 4 \\
Bimodal & 6 & 8 & 8 & 2 & 4 & 3 \\
Trimodal & 4 & 2 & 2 & 4 & 3 & 3 \\
Rodoviário & 10 & 10 & 10 & 10 & 10 & 10 \\
Hidroviário & 10 & 9 & 9 & 3 & 3 & 3 \\
Ferroviário & 2 & 1 & 1 & 4 & 5 & 3 \\
Brasil & 4 & 2 & 2 & 10 & 10 & 10 \\
EUA & 6 & 8 & 8 & 0 & 0 & 0 \\
\hline
\end{tabular}

Observa-se também que prevalecem rotas com dois modais entre as mais eficientes. Enquanto, entre as ineficientes, o número de rotas com dois e três modais se mostrou igualmente distribuído. Isso sugere que existe um limite para a intermodalidade. Rotas com muitas trocas de modais durante o percurso tendem a ser mais ineficientes.

O modal rodoviário está presente em todas as rotas, tanto nas eficientes quanto nas ineficientes. Porém, é preciso lembrar que esse modal tem características distintas 
nos dois países. Nos EUA, os caminhões são usados para fazer rotas curtas e a maior parte do trajeto é percorrida por trens três ou barcaças. No Brasil ocorre o contrário, os caminhões percorrem mais de $250 \mathrm{~km}$ usualmente (SALIN, 2016). Como as rotas brasileiras são as majoritárias entre as mais ineficientes, isso reforça a explicação de que o uso de caminhões para rotas demasiadamente longas é inadequado.

O modal hidroviário tem maior participação entre as rotas eficientes. Lembrando que prevalecem rotas norte-americanas entre as mais eficientes, e que o modal hidroviário deste país tem a característica de usar composições de barcaças muito maiores que no Brasil, este resultado sugere que o investimento neste modal (como a construção de hidrovias, por exemplo) gera mais eficiência quando a hidrovia não possui restrições de calado para as embarcações durante todas as estações do ano. Também é importante lembrar que o modal hidroviário é o mais afetado por eventos climáticos, como grandes secas. É importante ter alternativas viáveis de escoamento por outros modais em caso de catástrofe climática. Os próprios estudos feitos pelo Texas Transportation Instruments (TTI, 2008, 2012) evidenciam que os EUA já têm essa preocupação e estudam alternativas.

As rotas do estado de Mato Grosso até o porto de Santos aparecem entre as mais eficientes. $\mathrm{Na}$ verdade, é preciso levar em consideração dois fatores fundamentais: primeiro, foi considerada como se toda produção da mesorregião se escoasse por uma única rota, no caso, essas mesorregiões mato-grossenses produzem mais do que alguns estados norte-americanos, de certa forma, isso distorce a análise dos resultados; segundo, todas as rotas eficientes contam com a participação do modal ferroviário ou hidroviário. A grande produção mato-grossense não foi suficiente para descontar a ineficiência de um transporte exclusivamente hidroviário.

As primeiras rotas que usam o modal rodoviário exclusivamente ocupam as quadragésimas posições e pertencem aos produtores do Rio Grande Sul, que usam o porto do mesmo estado, percorrendo rotas curtas, quando comparadas as do Mato Grosso. A variável extensão da rota, tanto discricionária quanto não discricionária, não foi suficiente para corrigir essa distorção causada pelo pressuposto do modelo. O ideal seria trabalhar com dados reais sobre a quantidade de soja que, de fato, é transportada por cada rota. Mas esses dados não foram encontrados para um escopo tão grande quanto o de comparar países distintos. Apesar dessa inconsistência do modelo, os resultados apresentados pela DEA, dentro do contexto proposto, se mostraram coerentes. 
O senso comum e a literatura (SALIN, 2016) afirmam que as rotas norteamericanas tendem a ser menos onerosas (portanto, mais eficientes) do que as rotas brasileiras. Portanto, os cenários B e C, por indicarem oito rotas norte-americanas entre as mais eficientes, tendem corresponder melhor à realidade. Nota-se que ambos cenários são quase idênticos (mas o cenário $\mathrm{C}$ não contém a variável extensão da rota, que influencia o consumo de combustível e o fator de descarte). Como diz o adágio popular, “se você pode facilitar, para quê complicar?", uma vez que, a variável extensão da rota não afetou os resultados no modo discricionário e ela está indiretamente representada pela variável consumo de combustível, optou-se por discutir os demais resultados a partir do cenário $\mathrm{C}$. Ressalta-se também que o cenário $\mathrm{C}$ foi aquele que apresentou menor número de empates entre as DMUs eficientes.

Para uma análise na perspectiva de corredores, sugere-se o uso de uma média aritmética de todas as rotas que pertencem àquele corredor. A Tabela 15 mostra o ranking de eficiência por corredores. Os corredores são designados por estado de origem e porto exportador. Portanto, existem dezenove corredores: nove norteamericanos e dez brasileiros. Todos os corredores norte-americanos, exceto Missouri NPW, ocupam as primeiras posições do ranking. Como foi observado na Figura 18 (Subtópico 2.2.2 Caracterização do Contexto Norte-Americano), o estado fisicamente mais próximo do Golfo do Mississipi e, consequentemente, mais distante do Pacífico é o Missouri. A distância física a ser vencida pode explicar a baixa eficiência do corredor Missouri - NPW. O fato do corredor Missouri- Mississipi não estar no topo de eficiência, se deve ao fato de que o modelo considerou toda a produção das microrregiões sendo escoadas por uma mesma rota. A diferença de produção das microrregiões dos demais estados compensa a distância a ser vencida, assim como ocorre no caso brasileiro com o estado de Mato Grosso.

Tabela 15 Ranking de eficiência dos corredores.

\begin{tabular}{lcc}
\hline Corredor & Ranking & Média \\
\hline Iwoa - Mississipi & 1 & 0,9956467 \\
Illinois - Mississipi & 2 & 0,995327 \\
Indiana - Mississipi & 3 & 0,9180572 \\
Iwoa - NPW & 4 & 0,9022975 \\
Minesota - Mississipi & 5 & 0,837039 \\
Illinois - NPW & 6 & 0,8311039 \\
Minesota - NPW & 7 & 0,6788582 \\
Indiana - NPW & 8 & 0,6687484 \\
Missouri - Mississipi & 9 & 0,5730803
\end{tabular}


Mato Grosso - Santos

0,541439

Rio Grande do Sul - Rio Grande

0,4531575

Paraná - Paranaguá

0,4322949

Paraná - Santos

0,263277

Mato Grosso - Paranaguá

0,1830122

Mato Grosso do Sul - Santos

0,1810063

Goiás - Santos

0,0790015

Missouri - NPW

0,0615032

Mato Grosso do Sul - Paranaguá

0,0443934

Goiás - Paranaguá

0,0424617

Para analisar o quanto a capacidade estática de armazenamento contribuiu para a eficiência da rota, foi feita uma análise das folgas relacionadas a essas variáveis (armazéns internos e externos). Baseando-se em visitas a unidades armazenadores, assumiu-se que um silo padrão comporta 4.500 toneladas (75.000 sacas de $60 \mathrm{~kg}$ ).

Primeiramente as folgas foram divididas pela capacidade de um silo padrão. E se chegou a um número de silos necessários para melhorar a eficiência das rotas. Isso só ocorreu nas rotas cujas folgas para armazenamento eram significativamente diferentes de zero. Não foram observadas deficiências para estados norte-americanos. Lembrando que esses armazéns podem ser usados para qualquer produto agrícola e que a soja não é o principal produto agrícola norte-americano. Portanto, a presente análise restringe-se a afirmar que não há deficiência para o armazenamento tanto dentro das fazendas quanto fora, considerando-se apenas a soja como prioridade de armazenamento.

Já no caso brasileiro, houve déficit de armazenagem considerando-se quase todas as rotas. Quando houve déficits diferentes para rotas de um mesmo estado, adotou-se como déficit estadual, o maior valor. A Tabela 16 compila os resultados encontrados. Observa-se que quase todos os estados são deficitários tanto de armazéns internos quanto externos, exceto Mato Grosso que, pelo método proposto, possui capacidade estática de armazenagem fora das fazendas equivalente a um estado eficiente. No entanto, Mato Grosso continua deficitário em armazenagem interna, quando analisado pelo presente método. Oliveira et al. (2016), ao analisar este mesmo estado, conclui que a estratégia mais lucrativa para os produtores é a estocagem dentro das propriedades rurais.

Tabela 16 Déficit de capacidade de armazenagem estática estadual.

\section{Estado}

Rio Grande do Sul
Armazéns Externos

133
Armazéns Internos

1790 
Segundo artigo de Maia et al. (2013), publicado na Revista do BNDES (Banco Nacional do Desenvolvimento Econômico e Social), a ameaça no déficit de armazenagem tem levado o Governo Federal incentivar o crescimento da capacidade estática de armazenagem do país, por meio de um aumento substancial de recursos destinados ao atuais programas de armazenagem, além do lançamento do Programa para Construção e Ampliação de Armazéns (PCA). Segundo os autores, devem ter sido distribuídos a cooperativas, produtores e cerealistas, entre 2013 e 2017, R $\$ 25$ bilhões para a construção de novos armazéns privados, dos quais, pelo menos, $\mathrm{R} \$ 5$ bilhões entre 2013 e 2014. Os autores, no entanto, enfatizam que embora o intuito seja aumentar a eficácia da armazenagem, não havia, até aquele momento, estudos que avaliassem o impacto dos programas governamentais, bem como as alterações propostas pelo PCA, sobre os investimentos.

O presente estudo foi realizado considerando-se a safra de 2014/2015, pelo método, considerando-se apenas a produção de um produto agrícola em comparação com seu maior concorrente mundial, a infraestrutura para capacidade de armazenamento estático encontra-se deficitária. 


\section{Considerações Finais}

Este trabalho revisou a literatura atual sobre o tema corredores de transporte de carga e os métodos desenvolvidos para compará-los (benchmarking, em inglês). Em seguida, traçou um perfil sucinto dos cenários logísticos atuais no Brasil e nos EUA e apresentou a DEA, suas características, modelos, limitações e possíveis aplicações para o benchmarking de corredores de transporte de carga. Representa um avanço no entendimento aprofundado das matrizes do transporte inter-regional de carga do Brasil em relação a grãos (EMPRESA DE PLANEJAMENTO E LOGÍSTICA, 2017) em comparação com a realidade norte-americana.

O método se desenvolveu por meio da determinação das possíveis rotas de transporte, considerando diversas soluções modais. Procedeu-se com a coleta de dados e estimativas para as possíveis variáveis. A escolha das variáveis foi pautada, tendo em mente o escopo do projeto e os pilares da sustentabilidade (econômico, social e ambiental), além da própria disponibilidade de dados.

Logo depois foram realizadas análises estatísticas desses dados, visando a analisar a correlação e a significância estatística entre as variáveis analisadas. Por meio do teste de Wilcoxon, buscou-se investigar se as rotas (chamadas de DMUs, Decision Making Units) eram homogêneas para a tecnologia, i.e., exerciam atividades similares e utilizavam um grupo similar de recursos (HUA; HE, 2006). A análise econométrica demonstrou que existe forte correlação entre as variáveis de entrada e saída escolhidas para compor o modelo DEA. Além disso, observou-se significância estatística entre as variáveis independentes sobre a variável dependente em cada modelo analisado. A Análise de Componentes Principais (PCA) e o Teste de Wilcoxon visaram a determinar se as DMUs são homogêneas por usar uma tecnologia comum, conforme Hue e He (2006) e Heiser e Meulman (1992). As análises levaram a exclusão da variável fatalidades, única variável que representava o pilar social. Panagakos (2016) também foi levado a excluir as variáveis sociais da análise comparativa entre corredores de transporte de carga no contexto europeu.

Foi aplicado o modelo SBM (Slack-Based Measure) por meio do software MatLAB. Três cenários de configuração de variáveis de entrada (inputs), saída (outputs), indesejáveis e não discricionárias foram usados. Esses cenários foram chamados A, B e C. Todos geraram empates e foi usada a técnica quantitativa de 
desempate do índice composto (LETA et al., 2005). Os resultados dos três cenários se mostraram compatíveis com a realidade, mas o cenário C (sem a variável extensão da rota, em qualquer forma, i.e., discricionária ou não) se mostrou mais adequado e com menos empates. Este cenário foi adotado para análise dos corredores e déficit de armazéns.

Os resultados da DEA se mostraram adequados à expectativa, superando as dificuldades encontradas por trabalhos anteriores (PANAGAKO, 2016) em se desenvolver um método para comparação de corredores. Indicando que, entre as inúmeras aplicações de DEA já consolidadas, pode-se sugerir o desenvolvimento e o aperfeiçoamento de técnicas para comparação da eficiência de corredores de transporte de carga. O trabalho atingiu o objetivo proposto de analisar, quanto à eficiência, rotas e corredores domésticos nacionais de transporte de soja, levando em consideração os três pilares da sustentabilidade (econômico, social e ambiental).

Os resultados apontam que a infraestrutura logística brasileira, para o período analisado, não é suficiente para atender a demanda atual (respondendo a primeira pergunta de pesquisa: O Brasil pode gerir de maneira ainda mais eficiente o transporte de soja e fazer frente à competição global apenas utilizando infraestrutura já existente?). Os resultados também apontam que rotas com dois modais, sendo um o modal rodoviário percorrendo uma trajetória curta, e o outro modal hidroviário (preferencialmente) ou ferroviário, percorrendo uma rota longa, tendem a ser as rotas mais eficientes. O modal hidroviário já era apontado como o de menor custo pelos estudos de Marquéz e Cantillo (2013).

Ressalta-se que o modal hidroviário é sujeito a variações climáticas e não deve possuir restrições de calado (como o Pedral do Lourenço na Bacia Amazônica) para ser competitivo em termos de eficiência. Ele deve ser complementado com alternativas de modal ferroviário. A análise estática da capacidade de armazenamento apontou deficiências em todos os estados analisados, tanto para armazéns dentro quanto fora das propriedades rurais. Exceto para Mato Grosso que é deficitário exclusivamente de armazéns internos.

Dessa forma, as respostas à segunda (Qual a distribuição modal recomendável para o transporte de soja em cada corredor brasileiro?) e à terceira pergunta de pesquisa (Considerando o cenário atual e as projeções de crescimento do mercado, quais são os investimentos prioritários? Quais são as melhores práticas?) são que, para o escoamento da soja produzida no Rio Grande do Sul e no Paraná, sugerem-se planos de 
investimento e de incentivo para maior uso da rede ferroviário. No caso especifico do Rio Grande do Sul, a Lagoa dos Patos deve ser constante alvo de planos de investimento, expansão e manutenção. No caso do escoamento da safra dos estados da região Centro-Oeste, investimentos em projetos como Ferrovia Norte-Sul (que possibilitam o escoamento por portos da região Norte), assim como investimentos nos portos alvo, se mostram prioritários. Outro foco de investimentos deve ser a Hidrovia do Tapajós, focando em manutenção e na atenuação ou eliminação de obstáculos naturais ou artificiais que limitam o calado das embarcações que podem navegar na Hidrovia (por exemplo, o Pedral do Lourenço). Entende-se que o escoamento pelos portos da região Sudeste já atingiu seu ponto de saturação.

Para realização deste trabalho foram encontrados obstáculos na obtenção de dados e estimativas. Para trabalhos futuros, recomenda-se o uso do software EcoTransIT para cálculo de consumo energético e emissões. Após alterações em 2016, a metodologia de cálculo do software se encontra mais adequada a realidade brasileira, mas há restrições e limitações a serem investigadas e consideradas.

Também, recomenda-se a investigação de rotas que envolvam os projetos do Programa de Investimentos em Logística (PIL), estimando sua provável eficiência depois das obras finalizadas, comparando-se com o cenário atual. Poderia também ser feita uma análise temporal por meio de uma análise de janelas.

Para se evitar distorções do modelo causadas pela produção de algumas mesorregiões serem muito maiores que as outras, pode-se tentar o uso de um modelo cujos outputs sejam iguais a um como, por exemplo, o modelo Benefit of Doubt. Caso haja interesse em se investigar as capacidades de armazenagem estática e dinâmicado cenário agrícola brasileiro como um todo, recomenda-se o uso de algum modelo DEA dinâmico, como, por exemplo, um modelo alocativo de DEA.

Para teste de homogeneidade, não foi encontrada nenhuma aplicação de crossmatch test (ROSENBAUM, 2005) para homogeneidade em DEA. Recomendam-se maiores investigações sobre o tema. Assim como aplicações do índice triplo (MARIANO; REBELATTO, 2014) como técnica de desempate ou demonstração de outliers de eficiência. 


\title{
6. Referências
}

ABDI, Herve; WILLIAMS, Lynne J.. Principal component analysis: Overview. Wires Computational Statistics. San Diego, p. 433-459. ago. 2010.

\author{
ABIPEÇAS - ASSOCIAÇÃO BRASILEIRA DA INDðSTRIA DE AUTOPEÇAS. Levantamento da \\ frota circulante brasileira.São Paulo: Automotive Business, 2011. 16 p. Disponível em: \\ <http://www.automotivebusiness.com.br/pdf/pdf_125.pdf>. Acesso em: 23 mar. 2016.
}

ADLER, Nicole; GOLANY, Boaz. Evaluation of deregulated airline networks using data envelopment analysis combined with principal component analysis with an application to Western Europe. European Journal Of Operational Research. Londres, p. 260-273. jan. 2001.

ADLER, Nicole; YAZHEMSKY, Ekaterina. Improving discrimination in data envelopment analysis: PCA-DEA or variable reduction. European Journal Of Operational Research. Londres, p. 273-284. jan. 2010.

ALIANÇA (Rio Grande do Sul). Trevisa Investimentos. Frota. Disponível em: <http://www.trevisa.com.br/alianca/frota.html>. Acesso em: 04 jan. 2016.

ALL - AMÉRICA LATINA LOGÍSTICA S.A. (Brasil). Formulário de Referência. 9. ed. São Paulo: listadas/ResumoDemonstrativosFinanceiros.aspx?codigoCvm=17450\&idioma=pt-br>. Acesso em: 11 mar. 2015.

AHRANA, Administração da Hidrovia do Paraná. Dados e Informações Hidrovia do Rio Paraná. São Paulo: Ahrana, 2012. 52 p. Disponível em: <http://www.ahrana.gov.br/dados_informacoes.html〉. Acesso em: 31 dez. 2015.

Estatísticas de Movimentação de Carga. São Paulo: Ahrana, 2013. 26 p. Disponível em: <http://www.ahrana.gov.br/dados_operacionais.html>. Acesso em: 25 dez. 2015.

A Hidrovia do Paraná. São Paulo: Ahrana, 2005. 28 slides, color. Disponível em: <http://www.cooperhidro.com.br/palestras/ruy-ahrana.pdf>. Acesso em: 31 dez. 2015.

AMTRAK. Empire Builder: Route Guide. Seattle, 2010. 9 p. Disponível em: <https://www.amtrak.com/ccurl/229/381/Amtrak-Empire-Builder-Train-Route-Guide.pdf>. Acesso em: 25 fev. 2016

ANTAQ. Agência Nacional de Transportes Aquaviários. Secretaria de Portos. Transporte de Cargas nas Hidrovias Brasileiras 2010: Hidrovia do Sul. Brasília: Antaq, 2011. 29 p. Disponível em: <http://www.antaq.gov.br/portal/pdf/estatisticanavinterior/hidroviasul.pdf>. Acesso em: 25 jan. 2016.

Anuário Estatístico Aquaviário: Movimentação Portuária. 2014. Disponível em: <http://www.antaq.gov.br/anuario/>. Acesso em: 13 jul. 2015.

ARNOLD, John (Org.). Best Practices in Management of International Trade Corridors. Washington D.c: The World Bank Group, 2006. 71 p. (Transport Papers). Disponível em:

<http://documents.worldbank.org/curated/en/2005/02/9795860/best-practices-corridor-management>. Acesso em: 12 fev. 2016.

BANKER, R. D.; CHARNES, A.; COOPER, W. W.. Some models for estimating technical and scale inefficiencies in data envelopment analysis. Management Science. New York, p. 1078-1092. set. 1984. Disponível em: <http://pubsonline.informs.org/doi/abs/10.1287/mnsc.30.9.1078>. Acesso em: 27 abr. 2016. 
BANKER, R. D. et al. An introduction to data envelopment analysis with some of its models and their uses. Research In Governmental And Nonprofit Accounting. Nova Iorque, p. 125-163. jan. 1989.

BARR, R. S.; DURCHHOLZ, M. L.; SEIFORD, L. M. Peeling the DEA onion: layering and rank ordering DMUs using tiered DEA. Southern Methodist University, 2000.

BARTHOLOMEU, D. B.; CAIXETA-FILHO, J. V.. Quantification of the environmental impacts of road conditions in Brazil.Ecological Economics. New York, p. 1778-1786. abr. 2009. Disponível em: <https://www.scopus.com/record/display.uri?eid=2-s2.0-62549154860\&origin=resultslist\&sort=plf$\mathrm{f} \& \mathrm{src}=\mathrm{s} \& \mathrm{st} 1=$ caixeta+Filho\&st2;=\&sid=BA0D95A88DE5B39306211358DC88D2F8.ZmAySxCHIBxxT Xbnsoe $5 \mathrm{w}: 10 \&$ sot $=\mathrm{b} \& \mathrm{sdt}=\mathrm{b} \& \mathrm{sl}=26 \& \mathrm{~s}=\mathrm{AUTHOR}-$

NAME(caixeta+Filho)\&relpos=4\&citeCnt=1\&searchTerm;=> . Acesso em: 29 abr. 2016.

BAUMEL, Phillip. Measuring Bulk Product Transportation Fuel Efficiency. Transportation Research Forum. Washington, p. 79-88. set. 2011. Disponível em:

<http://www.trforum.org/journal/downloads/2011v50n1_05_FuelEfficiency.pdf〉. Acesso em: 18 fev. 2016.

BAUMEL, Philip; HURBURGH, Charles R.; LEE, Tenpao. Estimates of Total Fuel Consumption in Transporting Grain from Iowa to Major Grain Countries by Alternatives Modes and Routes. Iowa Grain Quality Iniciative. Iowa, p. 1-10. jan. 2015. Disponível em:

<http://www.extension.iastate.edu/grain/topics/EstimatesofTotalFuelConsumption.htm>. Acesso em: 18 fev. 2016.

BNSF - BURLINGTON NORTHERN SANTA FE CORPORATION BURLINGTON NORTHERN SANTA FE CORPORATION.BNSF Network Map. Burlington: Bnsf, 2016. 1 p. Disponível em: <https://www.bnsf.com/customers/pdf/maps/network-map.pdf>. Acesso em: 26 fev. 2016.

BOUSSOFIANE, A.; DYSON, R. G.; THANASSOULIS, E.. Applied data envelopment analysis. European Journal Of Operational Research. North-holland, p. 1-15. maio 1991. Disponível em: <http://www.sciencedirect.com/science/article/pii/037722179190331O>. Acesso em: 23 fev. 2015.

BUREAU OF TRANSPORTATION STATISTICS. National Transportation and Statistics.

Washington: United States Department Of Transportation.. Disponível em:

<http://www.rita.dot.gov/bts/sites/rita.dot.gov.bts/files/publications/national_transportation_statistics/htm 1/table_01_26.html_mfd>. Acesso em: 28 mar. 2016.

CAMIOTO, Flávia de Castro; MARIANO, Enzo Barberio; REBELATTO, Daisy Aparecida do Nascimento. Efficiency in Brazil's industrial sectors in terms of energy and sustainable development. Environmental Science \& Policy . London, p. 50-60. maio 2014. Disponível em: <http://www.sciencedirect.com/science/article/pii/S1462901113001561>. Acesso em: 29 jun. 2015.

CANADA GRAINS COUNCIL. Statistical Handbook. Canada: Canada Grains Council, 2000. (513). Disponível em: <http://www.canadagrainscouncil.ca/html/handbook.html〉. Acesso em: 26 jun. 2015.

CHARNES, A.; COOPER, W.w.; RHODES, E.. Measuring the efficiency of the decision making units. European Journal Of Operational Research. London, p. 429-444. ago. 1978. Disponível em: <http://www.utdallas.edu/ ryoung/phdseminar/CCR1978.pdf>. Acesso em: 29 jun. 2015.

CHARNES, A. et al. Foundations of data envelopment analysis for Pareto-Koopmans efficient empirical production functions.Journal Of Econometrics. Nova Iorque, p. 91-107. nov. 1985. Disponível em: <http://www.sciencedirect.com/science/article/pii/0304407685901332>. Acesso em: 27 abr. 2016.

CHOW, Garland; HEAVER, Trevor D.; HENRIKSSON, Lennart E.. Logistics Performance: Definition and Measurement: Data collection methods, sources and the measures used are identified.. International Journal Of Physical Distribution \& Logistics Management. New York, p. 17-28. dez. 1994. Disponível em: <http://www.emeraldinsight.com/doi/full/10.1108/09600039410055981>. Acesso em: 18 fev. 2016. 
COELLI, Timothy J.; RAO, D. S. Prasada; BATTESE, George E.. An Introduction to Efficiency and Productivity Analysis.2. ed. Massachussets: Springer, 1998. 341 p. Disponível em:

<http://facweb.knowlton.ohio-state.edu/pviton/courses/crp394/coelli_Intro_effic.pdf>. Acesso em: 27 abr. 2016.

COOK, W. D.; KRESS, M.; SEIFORD, L. M.. Prioritization models for frontier decision making units in DEA. European Journal Of Operational Research. North-holland, p. 319-323. jul. 1992

COOK, W. D.; TONE, K.; ZHU, J. Data envelopment analysis: Prior to choosing a model. Omega, v. 44 n. 1-4, 2014.

CONAB - Companhia Nacional de Abastecimento. Armazenagem agrícola no Brasil. Brasília: Conab, 2005. 25 p.Disponível em:

<http://www.conab.gov.br/OlalaCMS/uploads/arquivos/7420aabad201bf8d9838f446e17c1ed5..pdf>Aces sado em: Jul. 2016.

Séries Históricas. Brasília: Conab, 2014. 25 p . Disponível em:

<http://www.conab.gov.br/conteudos.php?a=1252\&t=\&Pagina_objcmsconteudos=3\#A_objcmsconteudos $>$. Acessado em: Jun. 2016.

Desenvolvimento do Trabalho de Atualização do Manual de Cálculo do Custo

Operacional Rodoviário e o Modelo de Inserção de Preço de Mercado. Brasília: Conab, 2016. 25 p.

Disponível em:

<http://www.conab.gov.br/OlalaCMS/uploads/arquivos/15_04_23_14_18_34_manual_de_calculo_de_cu sto_operacional_rodoviario_-_processo_conab_n.pdf>. Acesso em: 22 fev. 2016.

CONTRAN (CONSELHO NACIONAL DE TRÂNSITO). Lei n ${ }^{\circ} 7.408$, de 1985. Resolução 104 de 21/12/99. 2. Limites Legais. Brasília, BRASIL, Disponível em: <http://www1.dnit.gov.br/Pesagem/qfv pdf.pdf>. Acesso em: 26 dez. 2015.

DNIT - Departamento Nacional de Infraestrutura de Transportes. Anuário Estatístico das Rodovias Federais. Brasília: República Federativa do Brasil, 2010. 687 p. Disponível em:

<http://www.dnit.gov.br/download/rodovias/operacoes-rodoviarias/estatisticas-de-acidentes/anuario2010.pdf>. Acesso em: 06 abr. 2016.

DYSON, R. G. et al. Pitfalls and protocols in DEA. European Journal Of Operational Research. Londres, p. 245-259. dez. 2001.

ECO TRANSIT WORLD. Calculation. Disponível em: <http://www.ecotransit.org/calculation.en.html>. Acesso em: 09 mar. 2016.

ELLEN MACARTHOUR FOUNDATION. Circular Economy: Overview. 2016. Disponível em: <http://www.ellenmacarthurfoundation.org/circular-economy>. Acesso em: 07 mar. 2016.

EMATER. Acompanhamento da Safra: Safra 2014/2015. Porto Alegre: Emater, 2014. 6 p. (Séries Históricas). Disponível em: <http://www.emater.tche.br/site/servicos/informacoesagropecuarias.php\#acompanhamento-de-safra>. Acesso em: 26 jun. 2015.

EMPRESA DE PLANEJAMENTO E LOGÍSTICA. Matrizes do transporte inter-regional de carga no Brasil. Disponível em: <http://www.epl.gov.br/matrizes-do-transporte-inter-regional-de-carga-no-brasil〉. Acesso em: 26 jun. 2017.

EPE - Empresa de Pesquisa Energética. Estudo Associado ao Plano Decenal de Energia PDE 2021: Consolidação de Base de Dados do Setor de Transportes; 1970 - 2010. Brasília: Governo Federal, 2012. 54 p. Disponível em: <http://www.epe.gov.br/Petroleo/Documents/Estudos_28/Consolidação de Bases de Dados do Setor Transporte 1970-2010 - PDE 2021.pdf>. Acesso em: 18 fev. 2016.

ESTADOS UNIDOS. Association Of American Railroads. Rita Bts Bureau Of Transportation Statistics. 140,000-MILE PRIVATE RAIL NETWORK DELIVERS FOR AMERICA'S

ECONOMY. 2015. Disponível em: <http://freightrailworks.org/network/>. Acesso em: 24 mar. 2015 
.U.S. DEPARTMENT OF AGRICULTURE. . Study of Rural Transportation

Issues. Washington: Agricultural Marketing Service, 2010. Disponível em:

<http://www.ams.usda.gov/AMSv1.0/ams.fetchTemplateData.do?template=TemplateA\&navID=Agricult uralTransportation\&leftNav=AgriculturalTransportation\&page=ATRuralTransportationStudyHome\&des cription=Study of Rural Transportation Issues>. Acesso em: 09 fev. 2015.

EVANS, J. D. Straightforward statistics: For the behavioural sciences. Pacific Grove, CA: Brooks/Cole Publishing, 1996.

FÄRE, Rolf; GROSSKOPF, Shawna; LOVELL, C.a. Knox. Production Frontiers. Cambridge: Cambridge University Press, 1994. 296 p.

Federal Railroad Administration Office of Safety Analysis. Total Accidents/Incidents Jan - Dec (2010). Disponível em: <http://safetydata.fra.dot.gov/officeofsafety/publicsite/summary.aspx >. Acesso em: 07 abr. 2016.

FERREIRA, Alex Nunes. Estudo do Efeito de Acidentes na Hidrovia Tietê-Paraná: Aspectos Preventivos. 2010. 150 f. Dissertação (Mestrado) - Curso de Engenharia Naval e Oceânica, Escola Politécnica da Universidade de São Paulo, São Paulo, 2000. Cap. 4. Disponível em: <file:///C:/Users/Sony/Downloads/Dissertacao_Alex_Nunes_Ferreira.PDF>. Acesso em: 06 abr. 2016.

FERREIRA, Carlos Maurício de Carvalho; GOMES, Adriano Provezano. Introdução à Análise Envoltória de Dados: Teoria, Modelos e Aplicações. Viçosa: Universidade Federal de Viçosa, 2012. 389 p.

FERROESTE (Paraná). Secretaria de Infraestrutura e Logística. Mallha ferroviária. Disponível em: $<$ http://www.ferroeste.pr.gov.br/modules/conteudo/conteudo.php?conteudo=47>. Acesso em: 04 jan. 2016.

GLASS, G.V., PECKHAM, P.D. e SANDERS, J.R.. Consequences of failure to meet assumptions underlying fixed effects analyses of variance and covariance. Review of Educational Research, 42, 1972, pp: 237-288.

GOIÁS. Instituto Mauro Borges de Estatística e Estudos Socioeconômicos. Secretaria de Estado de Gestão e Planejamento. Estatísticas Municiapais: Séries Históricas. 2015. Disponível em: <http://www.seplan.go.gov.br/sepin/perfilweb/estatistica_bde.asp>. Acesso em: 26 jun. 2015.

GOLANY, B.; ROLL, Y. An Application Procedure for DEA. Omega. Londres, v.17 n.3, p. 237-250, 1989.

GOOGLE COMPANY (Estados Unidos). Google Earth. Disponível em:

<https://www.google.com/earth/>. Acesso em: 31 dez. 2016.

GREENHOUSE GAS PROTOCOL. World Resources Institute (wri). Calculating $\mathbf{C O}_{2}$ Emissions from Mobile Sources. 1.3 Washington: Greenhouse Gas Protoco, 2016. 11 p. Disponível em: <http://www.ghgprotocol.org/files/ghgp/tools/co2-mobile.pdf>. Acesso em: 17 mar. 2016.

HARALAMBIDES, Hercules; GUJAR, Girish. On balancing supply chain efficiency and environmental impacts: An eco-DEA model applied to the dry port sector of India. Maritime Economics \&

Logistics. London, p. 122-137. dez. 2012. Disponível em: <http://www.palgravejournals.com/mel/journal/v14/n1/full/mel201119a.html>. Acesso em: 18 fev. 2016.

HARWELL, M.R., RUBINSTEIN, E. N., HAYES, W.S. e OLDS, C.C. Summarizing Monte Carlo results in methodological research: the one- and two-factor fixed effects ANOVA cases. Journal of Educational Statistics, 17, 1992, pp. 315-339. 
HEISER, Willem J.; MEULMAN, Jacqueline J.. Homogeneity Analysis: Exploring the distribution of variables and their nonlinear relationship. Leiden: University Of Leiden, 1992. 45 p. Disponível em: <http://www.datatheory.nl/pdfs/92/92_12.pdf>. Acesso em: 24 nov. 2016.

HUA, Z.; HE, P. An Approach to Judge Homogeneity of Decision Making Units. POMS INTERNATIONAL CONFERENCE, Shangai: República da China, 2006. 18 p. Disponível em: <https://www.pomsmeetings.org/confpapers/005/005-0145.pdf>. Acesso em: 15 nov. 2016.

IBGE - Instituto Brasileiro de Geografia e Estatística. Ministério do Planejamento. Divisão Regional. Disponível em:

<http://www.ibge.gov.br/home/geociencias/geografia/default_div_int.shtm?c=1>. Acesso em: 31 dez. 2015.

Banco de Dados: Séries Históricas Estatísticas. Disponível em:

<http://seriesestatisticas.ibge.gov.br/lista_tema.aspx?op=0\&no=1 >. Acesso em: 21 dez. 2016.

ILLINOIS. Nass. Usda. Illinois Soybean: County Estimates. Illinois: Usda, 2014. 3 p. Disponível em: <http://www.nass.usda.gov/Statistics_by_State/Illinois/Publications/County_Estimates/2013/IL_Soybean s_Production_by_County.pdf>. Acesso em: 26 jun. 2015.

. Nass. Usda. Illinois Soybean: County Estimates. Illinois: Usda, 2015. 3 p. Disponível em: <http://www.nass.usda.gov/Statistics_by_State/Illinois/Publications/County_Estimates/2014/IL_Soybean s_Production_by_County.pdf $>$. Acesso em: 26 jun. 2015.

IMEA. Boletim Semanal de Soja. 358. ed. Cuiabá: Imea, 2015. 12 p. 19 de junho de 2015. Disponível em: <http://www.imea.com.br/upload/publicacoes/arquivos/R404_2015_06_19_BSSoja.pdf>. Acesso em: 26 jun. 2015.

. Mapa das Macrorregiões do IMEA. Cuiabá: Imea, 2011. 6 p. Disponível em: <http://www.imea.com.br/upload/publicacoes/arquivos/justificativamapa.pdf>. Acesso em: 26 jun. 2015.

INDE. Infraestrutura Nacional de Dados Espaciais. Visualizador de Mapas. Disponível em: <http://www.inde.gov.br/geo-servicos/visualizador-de-mapas>. Acesso em: 19 dez. 2016. Infraestrutura Nacional de Dados Espaciais. Visualizador de Mapas. Disponível em: <http://www.inde.gov.br/geoservicos/visualizador-de-mapas>. Acesso em: 19 dez. 2016.

INDIANA. Nass. Usda. Indiana Soybean: County Estimates. Indiana: Usda, 2014. 3 p. Disponível em: <http://www.nass.usda.gov/Statistics_by_State/Indiana/Publications/County_Estimates/2013/county_esti mates_soybean_Indiana_2013.pdf>. Acesso em: 26 jun. 2015.

Indiana Soybean: County Estimates. Indiana: Usda, 2015. 3 p. Disponível em:

<Indiana Soybean County Estimates 2014>. Acesso em: 26 jun. 2015.

INFORMA ECONOMICS (Estados Unidos). United Soybean Board. FARM TO MARKET A

SOYBEAN'S JOURNEY FROM FIELD TO CONSUMER. Menphis, Tennessee: Informa

Economics, 2012. Disponível em: <http://unitedsoybean.org/wp-

content/uploads/FarmToMarketStudy.pdf>. Acesso em: 09 fev. 2015.

Instituto da Mobilidade e dos Transportes Terrestres. TRANSPORTE FERROVIÁRIO RELATÓRIO

ANUAL DE SEGURANÇA DE 2011. São Paulo: Imtt, 2011. 78 p. Disponível em:

<http://www.imtt.pt/sites/IMTT/Portugues/IMTT/relatoriosectoriais/Documents/RelatorioAnualSeguranc aTranspFerroviario2011.pdf>. Acesso em: 07 abr. 2016.

IOWA. NASS. . Iowa Ag News - 2014 Soybean County Estimates. Iowa: Usda, 2014. 3 p. Disponível em:

<http://www.nass.usda.gov/Statistics_by_State/Iowa/Publications/County_Estimates/reports/2015/IA_Ct yE>. Acesso em: 26 jun. 2015. 
JIANG, Bao; LI, Jian. DEA-based Performance Measurement of Seaports in Northeast Asia: Radial and Non-radial Approach.The Asian Journal Of Shipping And Logistics. Xangai, p. 219-236. dez. 2009. Disponível em: <http://www.sciencedirect.com/science/article/pii/S2092521209800035>. Acesso em: 18 fev. 2016.

KENGPOL, Athakorn; TUAMMEE, Sopida; TUOMINEN, Markku. The development of a framework for route selection in multimodal transportation. The International Journal Of Logistics Management. London, p. 581-610. 02 jan. 2014. Disponível em: <http://www.emeraldinsight.com/doi/abs/10.1108/IJLM-05-2013-0064>. Acesso em: 29 jun. 2015.

KONTOVAS, Christos A.; PSARAFTIS, Harilaos N.. Transportation Emissions: Some Basics. In: PSARAFTIS, Harilaos N. (Ed.). Green Transportation Logistics: The Quest for Win-Win Solution. Suíça: Springer, 2016. Cap. 2. p. 41-80.

LETA, F.R.; SOARES DE MELLO, J.C.C. B.; GOMES, E. G., ÂNGULO MEZA, L.. Métodos De Melhora De Ordenação em DEA Aplicados à Avaliação Estática de Tornos Mecânicos. Investigação Operacional, v. 25, n. 2, p: 229-242, 2005.

MACROLOGÍSTICA (Brasil). CNI - Confederação Nacional da Indústria. Projeto Centro-Oeste Competitivo. São Carlos: na, 2013. 75 p. Disponível em:

$<$ http://arquivos.portaldaindustria.com.br/app/conteudo_18/2015/10/22/9958/ProjetoCentroOesteCompetitivo.pdf>. Acesso em: $31 \mathrm{dez} .2015$.

MACROLOGÍSTICA (Brasil). CNI - Confederação Nacional da Indústria. Projeto Sul Competitivo. São Carlos: na, 2013. 75 p. Disponível em: < http://www.macrologistica.com.br/images/stories/palestras/Projeto-Sul-Competitivo-RelatorioInstitucional-Porto\%20Alegre-28-de-Junho-2011.pdf > . Acesso em: 15 jun.2016

MAIA, Guilherme Baptista da Silva et al. Panorama da armazenagem de produtos agrícolas no Brasil. Revista do BNDES, Brasília, v. 12, n. 1, p.161-194, dez. 2013.

MARIANO, Enzo Barberio; REBELATTO, Daisy Aparecida do Nascimento. Transformation of wealth produced into quality of life: analysis of the social efficiency of nation-states with the DEA's triple index approach. Journal Of The Operational Research Society.New York, p. 1664-1681. out. 2014. Disponível em: <http://www.palgrave-journals.com/jors/journal/v65/n11/abs/jors2013132a.html>. Acesso em: 17 fev. 2016.

MÁRQUEZ, Luis; CANTILLO, Víctor. Evaluating strategic freight transport corridors including external costs. Transportation Planning And Technology. Londres, p. 529-546. set. 2013. Disponível em: <http://www.tandfonline.com/doi/abs/10.1080/03081060.2013.830892>. Acesso em: 13 fev. 2016.

MATSUDA, Tadayoshi; GOLDSMITH, Peter D. World Soybean Production: Area Harvested, Yield, and Long-Term Projections. International Food and Agribusiness Management Review. Illinois, Volume 12, Issue 4, 2009. Disponível em: < http://ageconsearch.umn.edu/bitstream/92573/2/20091023_Formatted.pdf> Acessado em: 08 agost. 2016

MELO, Isotilia Costa et al. Medindo a eficiência de rotas de transporte com análise envoltória de dados (DEA). In: XXX CONGRESSO ANPET, 30., 2016, Rio de Janeiro. Anais do XXX ANPET - Rio de Janeiro. Rio de Janeiro: Anpet, 2016. p. 1 - 14. MINISTÉRIO DOS TRANSPORTES, PORTOS E AVIAÇÃO CIVIL ${ }^{\mathrm{a}}$. Disponível em: <http://www.transportes.gov.br/transporte-rodoviariorelevancia.html> Acesso em: 20 out. 2016.

MINISTÉRIO DO DESENVOLVIMENTO, INDÚSTRIA E COMÉRCIO EXTERIOR (MDIC). Aliceweb2. Disponível em: <http://aliceweb.mdic.gov.br/>. Acesso em: 20 out. 2016.

MINISTÉRIO DO DESENVOLVIMENTO, INDÚSTRIA E COMÉRCIO EXTERIOR (MDIC). Disponível em: http://www.desenvolvimento.gov.br/sitio/interna/interna.php?area=5\&menu=4761 Acesso em: 13 jul.2015 
MINISTÉRIO DOS TRANSPORTES, PORTOS E AVIAÇÃO CIVIL ${ }^{\mathrm{b}}$. Transportes 2015. Brasília: Governo Federal, 2016. 81 p. Disponível em:

$\langle$ http://www.transportes.gov.br/images/2016/05/Transportes2015Versao_Web.pdf $>$. Acesso em: 20 out. 2016.

MINESOTA. Nass. Usda. Minesota Ag News - 2014 Soybean County Estimates. Minesota: Usda, 2014. 3 p. Disponível em:

<http://www.nass.usda.gov/Statistics_by_State/Minesota/Publications/County_Estimates/2015/MN_CtyE st_Soybean_13-14.pdf>. Acesso em: 26 jun. 2015.

MISSOURI. Nass. Usda. Missouri Soybean: County Estimates. Missouri: Usda, 2014. 3 p. Disponível em:

<http://www.nass.usda.gov/Statistics_by_State/Missouri/Publications/County_Estimates/2013/Soybean_ Production_by_County.pdf $>$. Acesso em: 26 jun. 2015.

Missouri Soybean: County Estimates. Missouri: Usda, 2015. 3 p. Disponível

em:

<http://www.nass.usda.gov/Statistics_by_State/Missouri/Publications/County_Estimates/2014/Soybean_ Production_by_County.pdf>. Acesso em: 26 jun. 2015.

MIT MEDIA LAB. The Observatory of Economic Complexity (OEC). 2017. Disponível em: <http://atlas.media.mit.edu/en/>. Acesso em: 04 abr. 2017.

MOYANO, Humberto et al. Green Corridors Handbook Volume I: 1. Gijon: Eu's Freight Transport Logistics Action, 2013. 75 p. (PLAN ON GREEN CORRIDORS ISSUES). Disponível em: <http://www.supergreenproject.eu/docs/public/Handbook-I.pdf>. Acesso em: 12 fev. 2016.

MURRAY, Alan; SKENE, Keith; HAYNES, Kathryn. The Circular Economy: An Interdisciplinary Exploration of the Concept and Application in a Global Context. Journal Of Business Ethics. London, p. 1-12. 12 maio 2015. Disponível em: <http://link.springer.com/article/10.1007/s10551-015-2693-2>. Acesso em: 07 mar. 2016.

MURRAY, David. BARGE FLEET HOLDING STEADY, GETTING YOUNGER. The Waterway Journal Weekly. Saint Louis, p. 1-1. jan. 2016. Disponível em:

<http://waterwaysjournal.net/Magazine/ThisWeeksTopNews/BargeFleetHoldingSteady,GettingYounger. aspx>. Acesso em: 28 mar. 2016.

National Highway Traffic Safety Administration. State Traffic Safety Info. Disponível em: <http://www-nrd.nhtsa.dot.gov/departments/nrd-30/ncsa/STSI/USA WEB REPORT.HTM>. Acesso em: 07 abr. 2016.

NASS - National Agricultural Statistics Services. Statistics by State. Disponível em: < https://www.nass.usda.gov/Statistics_by_State/> Acessado em: Jun. 2016

NET PORT KARL SHAMN (Suécia). East West Transport Corridor. Task 3B Final Report: GREEN CORRIDOR MANUAL. Estocolmo: Löwex Trycksake, 2012. 100 p. Disponível em:

<http://www.ewtc2.eu/media/310370/ewtcii_manual_lowres.pdf>. Acesso em: 13 fev. 2016.

NEVES, Mariana. Frota total de locomotivas brasileiras cresce em 126 unidades: Estudos de Mercado. Revista Ferroviária, São Paulo, n. 1, p.56-58, jan. 2012. Disponível em:

<http://www.revistaferroviaria.com.br/upload/Todas as locomotivas 2011.pdf>. Acesso em: 26 jan. 2016.

NOAA National Oceanic and Atmospheric Administration. Distances Between United States Ports. 12. ed. Washington: Noaa, 2012. 56 p. Disponível em: <http://www.nauticalcharts.noaa.gov/nsd/distancesports/distances.pdf>. Acesso em: 25 fev. 2016. 
OECD - THE ORGANIZATION FOR ECONOMIC COOPERATION AND DEVELOPMENT. The Impacts of Globalisation on International Maritime Transport Activity: Past trends and future perspectives. Guadalajara: Oecd, 2009. 31 p. Disponível em:

<http://www.oecd.org/greengrowth/greening-transport/41380820.pdf>. Acesso em: 04 abr. 2017.

OJIMA, Andréa Leda Ramos de Oliveira. ANÁLISE DA MOVIMENTAÇÃO LOGíSTICA E COMPETITIVIDADE DA SOJA BRASILEIRA: UMA APLICAÇÃO DE UM MODELO DE EQUILÍBRIO ESPACIAL DE PROGRAMAÇ̃̃o QUADRÁTICA. 2004. 79 f. Dissertação

(Mestrado) - Curso de Mestre em Engenharia Elétrica, Faculdade de Engenharia Elétrica e Computação, Universidade de Caminas, Campinas, 2004. Cap. 1. Disponível em:

<http://www.bibliotecadigital.unicamp.br/document/?code=vtls000317206>. Acesso em: 25 fev. 2015.

OLIVEAU, Etienne. China e Peru discutem ferrovia que pode ligar Brasil ao Pacífico. Radio France Internacional: Agência Reuteurs, Paris, v. 1, n. 1, p.1-3, 16 set. 2016. Disponível em:

<http://br.rfi.fr/brasil/20160916-china-e-peru-discutem-ferrovia-que-pode-ligar-brasil-ao-pacificobioceanica>. Acesso em: 27 out. 2016.

OLIVEIRA, Andrea Leda Ramos de; CICOLIN, Lucas Oliveira de Melo. Evaluating the logistics performance of Brazil's corn exports: a proposal of indicators. African Journal Of Agricultural Research. Cidade do Cabo, p. 693-700. fev. 2016.

OLIVEIRA, Ordiley Aparecido; GRZEBIELUCKAS, Cleci; NASCIMENTO, Andréia Rezenda da Costa; MALDONATO, Thiago Vargas. Custos de armazenagem de soja: qual a melhor estratégia, vender na safra ou armazenar? Custos e Agronegócios Online. Jan/Mar, 12 (1), 265-281, 2016.

PANAGAKOS, George. Green Corridors Basics. In: PSARAFTIS, Harilaos N. (Ed.). Green

Transportation Logistics: The Quest for Win-Win Solution. Switzerland: Springer, 2016. Cap. 3. p. 81121. (International Series in Operations Research \& Management Science). Disponível em: <http://www.springer.com/gp/book/9783319171746>. Acesso em: 12 fev. 2016.

PANAGAKOS, George et al. Green Corridors Handbook Volume II. Athens: Eu's Freight Transport Logistics Action, 2013. 55 p. Disponível em: <http://www.supergreenproject.eu/docs/public/HandbookII.pdf>. Acesso em: 12 fev. 2016.

PANAGAKOS, George; PSARAFTIS, Harilaos. How green are the TEN-T core network corridors? In: TRANSPORT RESEARCH ARENA, 1., 2014, Paris. How green are the TEN-T core network corridors?. Paris: Lloyd's Register Foundation, 2014. p. 1 - 10. Disponível em: <http://www.lrf-ntuacoe.gr/files/2013/12/C8-Panagakos-Psaraftis-TRA-20141.pdf>. Acesso em: 16 fev. 2016.

PANAGAKOS, George; PSARAFTIS, Harilaos N.; HOLTE, Even Ambros. Green Corridors and Their Possible Impact on the European Supply Chain. In: LEE, Chung-yee; MENG, Qiang (Ed.). Handbook of Ocean Container Transport Logistics: Making Global Supply Chains Effective. Singapura: Springer, 2014. p. 521-550. (International Series in Operations Research \& Management Science). Disponível em: <http://www.springer.com/gb/book/9783319118901>. Acesso em: 12 fev. 2016.

PEIXOTO, Nathane Eva Santos; RIBEIRO, Hugo Alves Silva; GRANEMANN, Sergio Ronaldo. Gargalos Logísticos do Escoamento da Safra de Grãos: Consolidação dos Problemas Apontados por Meio da Revisão Sistemática da Literatura. In: XXX CONGRESSO DA ASSOCIAÇÃO NACIONAL DE PESQUISA E ENSINO EM TRANSPORTES (ANPET), 30, 2016, Rio de Janeiro. XXX Anais do ANPET - Rio de Janeiro. São Paulo: Anpet, 2016. p. 1 - 10.

PEREIRA, Renée; CASTRO, Sérgio. Exportar pelo Norte começa a ser uma realidade. O Estado de São Paulo. São Paulo, p. 1-3. 07 jun. 2014. Disponível em:

<http://economia.estadao.com.br/noticias/geral,exportar-pelo-norte-comeca-a-ser-realidade,1507450>. Acesso em: 31 dez. 2015.

PETROLI, Viviane (Org.). Em oito meses 6,5 milhões $t$ de grãos passam por terminal de Rondonópolis. Agro Olhar. Cuiabá, p. 1-1. 24 jun. 2014. Disponível em: <http://www.olhardireto.com.br/agro/noticias/exibir.asp?id=16004>. Acesso em: 22 fev. 2016. 
PORT OF GRAYS HARBOUR. Connections to Major Railroads. Disponível em: <http://www.portofgraysharbor.com/downloads/PGH_Rail_USConnections.pdf>. Acesso em: 25 fev. 2016.

QUORUM COORPORATION (Estados Unidos). Railway Capacity Background \& Overview. Edmonton: Quorum Cooporation, 2005. 4 p. Disponível em: <http://www.quorumcorp.net/Downloads/Papers/RailwayCapacityOverview.pdf>. Acesso em: 26 jan. 2016.

ROCHA, Claúdia Bueno; PARRÉ, José Luiz. Estudo da Distribuição Espacial do Setor Agropecuário do Rio Grande do Sul.Análise Econômica. Porto Alegre, p. 139-160. set. 2009. Disponível em: <http://seer.ufrgs.br/AnaliseEconomica/article/view/5159>. Acesso em: 25 jan. 2016.

ROSENBAUM, Paul R.. An exact distribution-free test comparing two multivariate distributions based on adjacency.Journal Of Royal Statistical Society. Londres, p. 515-530. out. 2005.

RUMO ALL (Brasil). All - América Latina Logística. ALL - Operações Ferroviárias: Mapa de Atuação. Disponível em: 〈http://pt.rumoall.com/conteudo_pti.asp?idioma=0\&tipo=43399\&conta=45>. Acesso em: 31 dez. 2015.

RUSSO, R. Statistics for the Behavioural Sciences: An introduction. New York, NY: Taylor \& Francis Group, 2004.

SALIN, D. Soybean Transportation Guide: Brazil, 2014, U.S. Dept. of Agriculture. Agricultural Marketing Service, 2016 Disponível em: < https://www.ams.usda.gov/sites/default/files/media/Brazil\%20Soybean\%20Transportation\%20Guide\%20 2015.pdf > Acessado em: Out. 2016.

SEAB. Estimativas de Safra. 2015. Disponível em: <http://www.agricultura.pr.gov.br/>. Acesso em: 26 jun. 2015.

SEMPREBOM, Pedro Antônio. Perdas no Transporte Agrícola. 2009. 57 f. Dissertação (Mestrado) Curso de Mba em Ciência Política e Desenvolvimento Estratégico, Xiv Ciclo de Estudos de Política e Estratégia, Escola Superior de Guerra, Londrina, 2009. Disponível em:

<http://www.adesg.net.br/arquivos/biblioteca/perdas-no-transporte-agricola.pdf>. Acesso em: 23 mar. 2016

SIGA. Associação dos Produtores de Soja de Mato Grosso do Sul. Circular Técnica: Acompanhamento da Safra 2013/2014. 56. ed. Campo Grande: Siga, 2014. 9 p. Disponível em: $<$ http://sigaweb.aprosojams.org.br/>. Acesso em: 26 jun. 2015.

. Associação dos Produtores de Soja de Mato Grosso do Sul. Circular Técnica: Acompanhamento de Safra 2014/2015. 101. ed. Campo Grande: Siga, 2015. 11 p. Disponível em: <http://sigaweb.aprosojams.org.br/>. Acesso em: 26 jun. 2015.

SOY ILLINOIS. Illinois Soybean Association. FACTS \& STATISTICS FOR THE ILLINOIS SOYBEAN INDUSTRY. Springfield: Illinois Soybean Association, 2012 a 27 p. Disponível em: <http://www.ilsoy.org/_data/mediacenter/files/1580.pdf>. Acesso em: 26 fev. 2016.

Resources in Illinois for Soybean Buyers. Springfield: Soybean 2012 . 6 p. Disponível em: <http://www.ilsoy.org/sites/default/files/1367.pdf>. Acesso em: 26 fev. 2016.

SOY TRANSPORTATION COALITION. . Fuel Efficiency. 2016. Disponível em: <http://www.soytransportation.org/Stats/Modal_FuelEfficiency.pdf>. Acesso em: 19 fev. 2016.

SPH. Superintendência dos Portos e Hidrovias do Rio Grande do Sul. Disponível em: < http://www.sph.rs.gov.br/sph_2006/content/hidrovias/hidroviarias_apresentacao.php > Acesso em: 20 out. 2016. 
STATISTA - THE STATISTICS PORTAL. Average age of freight rail cars in the United States from 2005 to 2011 (in years). Disponível em: <http://www.statista.com/statistics/245305/age-of-us-freightrail-cars/>. Acesso em: 28 mar. 2016.

TTI - Texas Transportation Institute. A Modal Comparation of Domestic Freight Transportation Effects on the General Public: Final Report. Houston: National Waterway Foundation, 2007. 69 p. Disponível em: <http://www.marad.dot.gov/wp-

content/uploads/pdf/Phase_II_Report_Final_121907.pdf>. Acesso em: 19 fev. 2016.

\section{A Modal Comparation of Domestic Freight Transportation Effects on the}

General Public: Final Report. 2. ed. Houston: National Waterway Foundation, 2012. 59 p. Disponível em: <http://www.nationalwaterwaysfoundation.org/study/FinalReportTTI.pdf>. Acesso em: 19 fev. 2016.

TONE, Kaoru. A slacks-based measure of efficiency in data envelopment analysis. European Journal Of Operational Research. London, p. 498-509. 01 maio 2001.

TONGZON, Jose. E• ciency measurement of selected Australian and other international ports using data envelopment analysis. Transportation Research. New York, p. 107-122. jan. 2001.

UEDA, Tohru; HOSHIAI, Yoko. Application of principal component analysis for parsimonious summarization of DEA inputs and/or outputs. Journal Of The Operations Research Society Of Japan. Tóquio, p. 466-478. dez. 1997.

US Corps Of Engineers. U.s. Army. Planning Center of Expertise for Inland Navigation (PCXIN). 2016. Disponível em: <http://outreach.lrh.usace.army.mil/>. Acesso em: 25 fev. 2016.

US Soybean Export Council. Transporting U.S. Soybeans to Export Markets. In: US Soybean Export Council. U.S. Soy: International Buyers' Guide. Washington: U.s. Soybean Export Council, 2013. p. 46. Disponível em: <http://ussec.org/wp-content/uploads/2012/08/Preface.pdf〉. Acesso em: 03 nov. 2016.

VECTURA (Suécia). Swedish Transport Administration (trafikverket). BGLC task 3:1 - Deliverable 1: Inventory of actors, transport volumes and infrastructure in the Bothnian Green Logistic Corridor. Estocolmo: European Union, 2012. 79 p. Disponível em: <http://www.bothniangreen.se/wpcontent/uploads/2014/02/BGLC_Task3_1_Final.pdf>. Acesso em: 13 fev. 2016.

VIEIRA, Nair de Moura. Caracterização da Cadeia Produtiva da Soja em Goiás. 2002. 123 f. Dissertação (Mestrado) - Curso de Engenharia de Produção, Engenharia de Produção, Universidade Federal de Santa Catarina, Florianópolis, 2002. Disponível em:

<https://repositorio.ufsc.br/handle/123456789/83611>. Acesso em: 31 dez. 2015.

Waterways Council. Waterways Systems. 2016. Disponível em:

<http://waterwayscouncil.org/waterways-system/>. Acesso em: 26 fev. 2016.

YAMADA, Y.; MATUI, T.; SUGIYAMA, M. New analysis of efficiency based on DEA. Journal of the Operations Research Society of Japan, v. 37, p. 158-67, 1994.

WOOLDRIDGE, Jeffrey M. Introdução à Econometria: Uma Abordagem Moderna. 4. ed. São Paulo: Thomson, 2011. $725 \mathrm{p}$.

ZACHARIOUDAKIS, P. G. et al. Deliverable D4.4: Benchmarking Green Corridors With Smart ICT. Atenas: National Technical University Of Athens, 2013. 143 p. (Theme Title: Transport (including Aeronautics)). Disponível em: <http://www.supergreenproject.eu/docs/public/D4.4v2.PDF>. Acesso em: 13

fev.

2016. 


\section{APÊNDICES}

\section{APÊNDICE A - Dados Utilizados}

Tabela 17 Dados utilizados.

Capacidade Estática de Armazenamento

\begin{tabular}{|c|c|c|c|c|c|c|c|c|c|c|}
\hline Código & $\begin{array}{l}\text { Consumo de } \\
\text { Combustível } \\
\text { (l) }\end{array}$ & $\begin{array}{l}\text { Área } \\
\text { Plantada } \\
\text { (mil. de } \\
\text { hec.) }\end{array}$ & $\begin{array}{l}\text { Emissões } \\
\text { (kg de CO } \\
2 \mathrm{eq})\end{array}$ & $\begin{array}{l}\text { Fator de } \\
\text { Descarte } \\
\text { (adimensional) }\end{array}$ & $\begin{array}{l}\text { Fatalidades } \\
\text { (adimensional) }\end{array}$ & $\begin{array}{l}\text { Soja Transportada } \\
\text { (mil. de t.) }\end{array}$ & $\begin{array}{l}\text { Dentro da } \\
\text { Fazenda }(t)\end{array}$ & $\begin{array}{l}\text { Fora da } \\
\text { Fazenda (t) }\end{array}$ & $\begin{array}{l}\text { Extensão } \\
\text { da Rota } \\
(\mathbf{k m})\end{array}$ & Rota \\
\hline EH1 & 33987,63 & 438,00 & 124,67 & 0,13 & 9,00 & 1369420,86 & 14151971,00 & 6667756,00 & 650,3 & New Madrid - Golfo do Mississipi \\
\hline ERF1 & 570521,24 & 616,00 & 11560,99 & 0,64 & 2908,50 & 2393696,94 & 39489441,00 & 39734379,00 & 4267,2 & Edgard - NPW \\
\hline ERF10 & 281827,76 & 627,00 & 3920,75 & 0,48 & 1455,67 & 1784318,53 & 40822992,00 & 19595036,00 & 3004,9 & Lac Qui Parle - NPW \\
\hline ERF11 & 266092,99 & 552,00 & 3453,89 & 0,46 & 1352,97 & 1706645,99 & 40822992,00 & 19595036,00 & 2991,9 & Conttonwood - NPW \\
\hline ERF12 & 238382,38 & 493,00 & 2993,22 & 0,41 & 1307,15 & 1537856,53 & 40822992,00 & 19595036,00 & 2986,1 & Faribault - NPW \\
\hline ERF13 & 286951,62 & 442,00 & 4462,56 & 0,39 & 2879,16 & 1452890,27 & 14151971,00 & 6667756,00 & 3700,3 & Nodaway - NPW \\
\hline ERF14 & 230205,75 & 341,00 & 4959,08 & 0,29 & 4502,61 & 1065670,59 & 14151971,00 & 6667756,00 & 3818,8 & Audrain - NPW \\
\hline ERF15 & 334596,85 & 438,00 & 5381,09 & 0,37 & 3697,48 & 1369420,86 & 14151971,00 & 6667756,00 & 4554,8 & New Madrid - NPW \\
\hline$E R F 2$ & 522894,27 & 566,00 & 9171,40 & 0,61 & 2461,74 & 2285570,44 & 39489441,00 & 39734379,00 & 4206,0 & Champaign - NPW \\
\hline ERF3 & 479331,92 & 524,00 & 8586,39 & 0,56 & 2520,87 & 2083632,71 & 39489441,00 & 39734379,00 & 4214,1 & Mclean - NPW \\
\hline ERF4 & 544326,78 & 642,00 & 9395,73 & 0,58 & 3899,02 & 2171837,58 & 54430656,00 & 38917919,00 & 4620,0 & Plymouth - NPW \\
\hline ERF5 & 617219,30 & 565,00 & 14906,10 & 0,59 & 6206,86 & 2213830,83 & 54430656,00 & 38917919,00 & 4800,3 & Woodbury - NPW \\
\hline ERF6 & 461537,86 & 503,00 & 5387,83 & 0,53 & 2343,82 & 1992434,14 & 54430656,00 & 38917919,00 & 4498,5 & Webster - NPW \\
\hline ERF7 & 208698,23 & 279,00 & 2950,14 & 0,27 & 2468,05 & 1003565,21 & 32114087,00 & 24410789,00 & 3948,1 & Knox - NPW \\
\hline$E R F 8$ & 445556,94 & 469,00 & 9178,79 & 0,52 & 4033,91 & 1948290,88 & 32114087,00 & 24410789,00 & 4080,8 & Clinton - NPW \\
\hline ERF9 & 273995,17 & 47,00 & 7259,94 & 0,29 & 5761,43 & 1089157,42 & 32114087,00 & 24410789,00 & 4227,2 & Montgomery - NPW \\
\hline ERHI & 119700,58 & 642,00 & 3726,77 & 0,42 & 796,05 & 2393696,94 & 39489441,00 & 39734379,00 & 977,6 & Edgard - Golfo do Mississipi \\
\hline ERH10 & 119322,24 & 627,00 & 3214,23 & 0,32 & 978,43 & 1784318,53 & 40822992,00 & 19595036,00 & 1375,3 & Lac Qui Parle - Golfo do Mississipi \\
\hline ERH11 & 109157,14 & 552,00 & 2649,59 & 0,30 & 831,17 & 1706645,99 & 40822992,00 & 19595036,00 & 1356,6 & Cottonwood - Golfo do Mississipi \\
\hline
\end{tabular}




\begin{tabular}{|c|c|c|c|c|c|c|c|c|c|c|}
\hline ERH12 & 81459,51 & 493,00 & 943,45 & 0,27 & 275,49 & 1537856,53 & 40822992,00 & 19595036,00 & 1286,3 & Faribault - Golfo do Mississipi \\
\hline ERH13 & 96634,33 & 442,00 & 4310,89 & 0,26 & 2931,21 & 1452890,27 & 14151971,00 & 6667756,00 & 1083,2 & Nodaway - Golfo do Mississipi \\
\hline ERH14 & 48944,99 & 341,00 & 1287,87 & 0,19 & 1126,49 & 1065670,59 & 14151971,00 & 6667756,00 & 951,5 & Audrain - Golfo do Mississipi \\
\hline ERH2 & 116068,79 & 565,00 & 3710,10 & 0,40 & 832,34 & 2285570,44 & 39489441,00 & 39734379,00 & 982,6 & Champaign - Golfo do Mississipi \\
\hline ERH3 & 98935,56 & 503,00 & 2794,63 & 0,37 & 678,11 & 2083632,71 & 39489441,00 & 39734379,00 & 961,4 & Mclean - Golfo do Mississipi \\
\hline ERH4 & 119812,45 & 616,00 & 2422,38 & 0,38 & 929,65 & 2171837,58 & 54430656,00 & 38917919,00 & 1224,3 & Plymouth - Golfo do Mississipi \\
\hline ERH5 & 156640,84 & 566,00 & 5654,04 & 0,39 & 2313,13 & 2213830,83 & 54430656,00 & 38917919,00 & 1298,2 & Woodbury - Golfo do Mississipi \\
\hline ERH6 & 111765,68 & 524,00 & 2592,89 & 0,35 & 1112,14 & 1992434,14 & 54430656,00 & 38917919,00 & 1204,4 & Webster - Golfo do Mississipi \\
\hline ERH7 & 54516,37 & 279,00 & 2112,17 & 0,18 & 1770,30 & 1003565,21 & 32114087,00 & 24410789,00 & 961,9 & Knox - Golfo do Mississipi \\
\hline ERH 8 & 82348,96 & 469,00 & 2807,86 & 0,35 & 1196,86 & 1948290,88 & 32114087,00 & 24410789,00 & 796,0 & Clinton - Golfo do Mississipi \\
\hline ERH9 & 37480,90 & 47,00 & 838,76 & 0,20 & 603,69 & 1089157,42 & 32114087,00 & 24410789,00 & 745,7 & Montgomery - Golfo do Mississipi \\
\hline$F 1$ & 96249,41 & 902,00 & 1767,14 & 0,14 & 6,90 & 2348669,66 & 4549953,00 & 28732246,00 & 627,0 & Santa Maria - Rio Grande \\
\hline$F 2$ & 158919,08 & 1535,00 & 2917,76 & 0,27 & 5,91 & 4527862,00 & 2321959,00 & 30962392,00 & 537,0 & Londrina - Paranaguá \\
\hline$F 3$ & 119688,69 & 1497,00 & 2197,49 & 0,27 & 4,57 & 4415811,00 & 2321959,00 & 30962392,00 & 414,7 & Guarapuava - Paranaguá \\
\hline F4 & 151921,76 & 1188,00 & 2789,29 & 0,21 & 7,30 & 3504301,00 & 2321959,00 & 30962392,00 & 663,3 & Cascável - Paranaguá \\
\hline F5 & 40735,23 & 182,00 & 747,90 & 0,04 & 13,03 & 526437,12 & 1947286,00 & 7016459,00 & 1183,9 & Chapadão do Sul - Santos \\
\hline FHI & 117147,41 & 902,00 & 1019,56 & 0,28 & 5,00 & 2348669,66 & 4549953,00 & 28882287,00 & 640,0 & Santa Maria - Rio Grande \\
\hline$R 1$ & 621988,69 & 3463,00 & 71410,53 & 2,02 & 3948,79 & 9020409,31 & 4549953,00 & 28732246,00 & 593,0 & Ijuí - Rio Grande \\
\hline$R 10$ & 418526,12 & 1289,00 & 48050,99 & 0,84 & 11401,92 & 3737616,41 & 1947286,00 & 7016459,00 & 963,0 & Dourados - Paranaguá \\
\hline$R 11$ & 463725,20 & 1289,00 & 53240,30 & 0,84 & 12633,28 & 3737616,41 & 1947286,00 & 7016459,00 & 1067,0 & Dourados - Santos \\
\hline$R 12$ & 163806,18 & 421,00 & 18806,59 & 0,28 & 13663,36 & 1220739,25 & 1947286,00 & 7016459,00 & 1154,0 & Sidrolândia - Paranaguá \\
\hline$R 13$ & 162812,55 & 421,00 & 18692,51 & 0,28 & 13580,48 & 1220739,25 & 1947286,00 & 7016459,00 & 1147,0 & Sidrolândia - Santos \\
\hline$R 14$ & 72966,64 & 182,00 & 8377,30 & 0,12 & 14113,28 & 526437,12 & 1947286,00 & 7016459,00 & 1192,0 & Chapadão do Sul - Paranaguá \\
\hline$R 15$ & 59560,86 & 182,00 & 6838,19 & 0,12 & 11520,32 & 526437,12 & 1947286,00 & 7016459,00 & 973,0 & Chapadão do Sul - Santos \\
\hline$R 16$ & 851893,26 & 1977,00 & 97805,87 & 1,29 & 14964,11 & 5732615,00 & 1875807,00 & 12434499,00 & 1278,0 & Jataí - Paranaguá \\
\hline$R 17$ & 715243,71 & 1977,00 & 82117,14 & 1,29 & 12563,76 & 5732615,00 & 1875807,00 & 12434499,00 & 1073,0 & Jataí - Santos \\
\hline$R 18$ & 199421,28 & 468,00 & 22895,56 & 0,31 & 14800,18 & 1356822,00 & 1875807,00 & 12434499,00 & 1264,0 & Rio Verde - Paranaguá \\
\hline$R 19$ & 163449,72 & 468,00 & 18765,67 & 0,31 & 12130,53 & 1356822,00 & 1875807,00 & 12434499,00 & 1036,0 & Rio Verde - Santos \\
\hline
\end{tabular}




\begin{tabular}{|c|c|c|c|c|c|c|c|c|c|c|}
\hline$R 2$ & 100228,12 & 902,00 & 11507,19 & 0,53 & 2443,86 & 2348669,66 & 4549953,00 & 28732246,00 & 367,0 & Santa Maria - Rio Grande \\
\hline$R 20$ & 144894,43 & 443,00 & 16635,33 & 0,29 & 11357,73 & 1284631,00 & 1875807,00 & 12434499,00 & 970,0 & Cristalina - Santos \\
\hline$R 21$ & 2138823,38 & 1350,00 & 245558,32 & 2,20 & 20044,53 & 327876,67 & 14201140,00 & 28882287,00 & 1870,0 & Canarana - Paranaguá \\
\hline$R 22$ & 1906640,95 & 1350,00 & 218901,45 & 2,20 & 17868,58 & 327876,67 & 14201140,00 & 28882287,00 & 1667,0 & Canarana - Santos \\
\hline$R 23$ & 1167677,66 & 1912,00 & 134061,08 & 1,32 & 18286,62 & 5886300,00 & 14201140,00 & 28882287,00 & 1706,0 & Primavera do Leste - Paranaguá \\
\hline$R 24$ & 1060902,91 & 1912,00 & 121802,27 & 1,32 & 16614,45 & 5886300,00 & 14201140,00 & 28882287,00 & 1550,0 & Primavera do Leste - Santos \\
\hline$R 25$ & 1090712,86 & 3206,00 & 125224,75 & 0,93 & 24278,54 & 9836300,00 & 14201140,00 & 28882287,00 & 2265,0 & Sorriso - Paranaguá \\
\hline$R 26$ & 921688,49 & 3206,00 & 105819,06 & 0,93 & 20516,17 & 9836300,00 & 14201140,00 & 28882287,00 & 1914,0 & Sorriso - Santos \\
\hline$R 3$ & 35791,44 & 460,00 & 4109,22 & 0,27 & 1711,37 & 1197689,90 & 4549953,00 & 28732246,00 & 257,0 & Bagé - Rio Grande \\
\hline$R 4$ & 255876,86 & 1535,00 & 29377,23 & 1,02 & 4671,92 & 4527862,00 & 2321959,00 & 30962392,00 & 486,0 & Londrina - Paranaguá \\
\hline$R 5$ & 333271,71 & 1535,00 & 38262,93 & 1,02 & 6085,03 & 4527862,00 & 2321959,00 & 30962392,00 & 633,0 & Londrina - Santos \\
\hline$R 6$ & 181253,64 & 1497,00 & 20809,74 & 0,99 & 3393,39 & 4415811,00 & 2321959,00 & 30962392,00 & 353,0 & Guarapuava - Paranaguá \\
\hline$R 7$ & 358399,55 & 1497,00 & 41147,86 & 0,99 & 6709,88 & 4415811,00 & 2321959,00 & 30962392,00 & 698,0 & Guarapuava - Santos \\
\hline$R 8$ & 243263,69 & 1188,00 & 27929,11 & 0,79 & 5738,97 & 3504301,00 & 2321959,00 & 30962392,00 & 597,0 & Cascável - Paranaguá \\
\hline$R 9$ & 414811,45 & 1188,00 & 47624,51 & 0,79 & 9786,04 & 3504301,00 & 2321959,00 & 30962392,00 & 1018,0 & Cascável - Santos \\
\hline$R F 1$ & 210252,40 & 1535,00 & 8811,34 & 1,28 & 1061,32 & 4527862,00 & 2321959,00 & 30962392,00 & 634,5 & Londrina - Paranaguá \\
\hline$R F 10$ & 1564074,88 & 1350,00 & 92699,26 & 2,78 & 6540,66 & 327876,67 & 14201140,00 & 28882287,00 & 1981,0 & Canarana - Santos \\
\hline$R F 11$ & 772399,06 & 1912,00 & 36692,55 & 1,67 & 3978,81 & 5886300,00 & 14201140,00 & 28882287,00 & 1742,0 & Primavera do Leste - Santos \\
\hline$R F 12$ & 774569,96 & 3206,00 & 52352,94 & 1,17 & 9123,93 & 9836300,00 & 14201140,00 & 28882287,00 & 2222,0 & Sorriso - Santos \\
\hline$R F 2$ & 397403,95 & 3463,00 & 11848,76 & 2,55 & 306,19 & 9020409,31 & 4549953,00 & 28732246,00 & 639,0 & Ijuí - Rio Grande \\
\hline$R F 3$ & 531723,81 & 1289,00 & 33152,59 & 1,06 & 6619,75 & 3737616,41 & 1947286,00 & 7016459,00 & 1741,9 & Dourados - Santos \\
\hline RF4 & 153793,30 & 421,00 & 8546,38 & 0,35 & 4962,15 & 1220739,25 & 1947286,00 & 7016459,00 & 1601,9 & Sidrolândia - Santos \\
\hline$R F 5$ & 779261,84 & 1977,00 & 65290,76 & 1,62 & 9292,60 & 5732615,00 & 1875807,00 & 12434499,00 & 1462,0 & Jataí - Paranaguá \\
\hline RF6 & 182861,62 & 468,00 & 15272,19 & 0,39 & 9175,51 & 1356822,00 & 1875807,00 & 12434499,00 & 1452,0 & Rio Verde - Paranaguá \\
\hline$R F 7$ & 2031355,18 & 1350,00 & 191737,03 & 2,78 & 15161,14 & 327876,67 & 14201140,00 & 28882287,00 & 2069,0 & Canarana - Paranaguá \\
\hline$R F 8$ & 1062983,12 & 1912,00 & 97216,66 & 1,67 & 12770,81 & 5886300,00 & 14201140,00 & 28882287,00 & 1846,0 & Primavera do Leste - Paranaguá \\
\hline$R F 9$ & 1028611,68 & 3206,00 & 100629,55 & 1,17 & 19019,98 & 9836300,00 & 14201140,00 & 28882287,00 & 2429,0 & Sorriso - Paranaguá \\
\hline RFH1 & 473538,79 & 3463,00 & 8901,80 & 3,08 & 305,00 & 9020409,31 & 4549953,00 & 28882287,00 & 645,0 & Ijuí - Rio Grande \\
\hline
\end{tabular}




\begin{tabular}{|c|c|c|c|c|c|c|c|c|c|c|}
\hline RH1 & 672621,23 & 3463,00 & 47964,68 & 2,55 & 2631,57 & 9020409,31 & 4549953,00 & 28732246,00 & 710,0 & Ijuí - Rio Grande \\
\hline RH2 & 146729,79 & 902,00 & 9227,81 & 0,67 & 1939,03 & 2348669,66 & 4549953,00 & 28732246,00 & 606,0 & Santa Maria - Rio Grande \\
\hline RH3 & 86800,88 & 460,00 & 6080,74 & 0,34 & 2511,71 & 1197689,90 & 4549953,00 & 28732246,00 & 692,0 & Bagé - Rio Grande \\
\hline RH4 & 529047,97 & 3463,00 & 55584,85 & 2,55 & 3070,03 & 9020409,31 & 4549953,00 & 28732246,00 & 516,5 & Ijuí - Rio Grande \\
\hline RH5 & 91868,74 & 902,00 & 9205,19 & 0,67 & 1951,31 & 2348669,66 & 4549953,00 & 28732246,00 & 348,5 & Santa Maria - Rio Grande \\
\hline RH6 & 32503,49 & 460,00 & 3047,25 & 0,34 & 1265,44 & 1197689,90 & 4549953,00 & 28732246,00 & 245,5 & Bagé - Rio Grande \\
\hline$R H 7$ & 719267,99 & 3463,00 & 32235,16 & 2,55 & 1746,83 & 9020409,31 & 4549953,00 & 28732246,00 & 804,0 & Ijuí - Rio Grande \\
\hline RH8 & 149589,90 & 902,00 & 4066,21 & 0,67 & 827,89 & 2348669,66 & 4549953,00 & 28732246,00 & 666,0 & Santa Maria - Rio Grande \\
\hline RH9 & 91880,29 & 460,00 & 3864,33 & 0,34 & 1573,70 & 1197689,90 & 4549953,00 & 28732246,00 & 778,0 & Bagé - Rio Grande \\
\hline RHF1 & 689834,35 & 1977,00 & 18797,54 & 1,96 & 2348,41 & 5732615,00 & 1875807,00 & 12434499,00 & 1389,0 & Jataí - Santos \\
\hline RHF2 & 159960,04 & 468,00 & 4068,71 & 0,47 & 2102,29 & 1356822,00 & 1875807,00 & 12434499,00 & 1368,0 & Rio Verde - Santos \\
\hline RHF3 & 203999,59 & 443,00 & 10176,56 & 0,44 & 6426,64 & 1284631,00 & 1875807,00 & 12434499,00 & 1715,0 & Cristalina - Santos \\
\hline RHF4 & 77694,63 & 3206,00 & 5465,41 & 0,12 & 12913,59 & 9836300,00 & 14201140,00 & 28882287,00 & 2392,0 & Sorriso - Santos \\
\hline RHF5 & 37254,38 & 1350,00 & 2209,79 & 0,07 & 8567,94 & 327876,67 & 14201140,00 & 28882287,00 & 1987,0 & Canarana - Santos \\
\hline RHF6 & 24666,35 & 1912,00 & 1408,70 & 0,05 & 7719,94 & 5886300,00 & 14201140,00 & 28882287,00 & 1886,0 & Primavera do Leste - Santos \\
\hline$R H R 1$ & 752027,00 & 1977,00 & 41477,19 & 2,90 & 6255,65 & 5732615,00 & 1875807,00 & 12434499,00 & 1294,0 & Jataí - Santos \\
\hline RHR10 & 38078,02 & 1912,00 & 2880,67 & 0,10 & 11708,10 & 327876,67 & 14201140,00 & 28882287,00 & 1830,0 & Canaran - Santos \\
\hline RHR11 & 26440,07 & 1350,00 & 1955,26 & 0,07 & 11290,15 & 5886300,00 & 14201140,00 & 28882287,00 & 1813,0 & Primavera do Leste - Santos \\
\hline RHR12 & 25521,92 & 1350,00 & 1881,12 & 0,07 & 10861,30 & 5886300,00 & 14201140,00 & 28882287,00 & 1751,0 & Primavera do Leste - Santos \\
\hline RHR2 & 713898,44 & 1977,00 & 38398,32 & 2,90 & 5787,20 & 5732615,00 & 1875807,00 & 12434499,00 & 1232,0 & Jataí - Santos \\
\hline RHR3 & 174680,08 & 468,00 & 9436,63 & 0,69 & 6009,76 & 1356822,00 & 1875807,00 & 12434499,00 & 1273,0 & Rio Verde - Santos \\
\hline RHR4 & 165655,64 & 468,00 & 8707,91 & 0,69 & 5541,31 & 1356822,00 & 1875807,00 & 12434499,00 & 1211,0 & Rio Verde - Santos \\
\hline RHR5 & 220505,70 & 443,00 & 15262,83 & 0,65 & 10330,38 & 1284631,00 & 1875807,00 & 12434499,00 & 1642,0 & Cristalina - Santos \\
\hline RHR6 & 211961,42 & 443,00 & 14572,88 & 0,65 & 9861,93 & 1284631,00 & 1875807,00 & 12434499,00 & 1580,0 & Cristalina - Santos \\
\hline RHR7 & 81251,73 & 3206,00 & 6762,58 & 0,17 & 16478,15 & 9836300,00 & 14201140,00 & 28882287,00 & 2297,0 & Sorriso - Santos \\
\hline RHR8 & 79070,98 & 3206,00 & 6586,48 & 0,17 & 16049,30 & 9836300,00 & 14201140,00 & 28882287,00 & 2235,0 & Sorriso - Santos \\
\hline RHR9 & 39383,05 & 1912,00 & 2986,05 & 0,10 & 12136,95 & 327876,67 & 14201140,00 & 28882287,00 & 1892,0 & Canarana - Santos \\
\hline
\end{tabular}




\section{APÊNDICE B - Resultados}

Tabela 18 Resultados do Cenário A.

\begin{tabular}{|c|c|c|c|}
\hline \multicolumn{4}{|c|}{ CENÁRIO A } \\
\hline Código & Ranking & $\begin{array}{c}\text { Eficiência } \\
\text { (Índice Composto) }\end{array}$ & $\begin{array}{c}\text { Rota } \\
\text { (Origem - Destino) }\end{array}$ \\
\hline RHR12 & 1 & 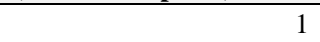 & Primavera do Leste - Santos \\
\hline RHR11 & 2 & 0,999924208 & Primavera do Leste - Santos \\
\hline RHF6 & 3 & 0,9992337 & Primavera do Leste - Santos \\
\hline ERH12 & 4 & 0,9983988 & Faribault - Golfo do Mississipi \\
\hline ERH4 & 5 & 0,994530096 & Plymouth - Golfo do Mississipi \\
\hline RHF5 & 6 & 0,994052817 & Canarana - Santos \\
\hline ERH6 & 7 & 0,993528752 & Webster - Golfo do Mississipi \\
\hline ERH9 & 8 & 0,991330305 & Montgomery - Golfo do Mississipi \\
\hline ERH3 & 9 & 0,987386456 & Mclean - Golfo do Mississipi \\
\hline ERH5 & 10 & 0,985251633 & Woodbury - Golfo do Mississipi \\
\hline ERH2 & 11 & 0,983401583 & Champaign - Golfo do Mississipi \\
\hline ERH1 & 12 & 0,983119626 & Edgard - Golfo do Mississipi \\
\hline ERH7 & 13 & 0,982636184 & Knox - Golfo do Mississipi \\
\hline FH1 & 14 & 0,963072603 & Santa Maria - Rio Grande \\
\hline RHF4 & 15 & 0,950207965 & Sorriso - Santos \\
\hline RHR8 & 16 & 0,945019284 & Sorriso - Santos \\
\hline$F 1$ & 17 & 0,943406087 & Santa Maria - Rio Grande \\
\hline RHR7 & 18 & 0,918103571 & Sorriso - Santos \\
\hline ERF3 & 19 & 0,889410602 & Mclean - NPW \\
\hline$F 4$ & 20 & 0,888194602 & Cascável - Paranaguá \\
\hline$E R F 2$ & 21 & 0,88576899 & Champaign - NPW \\
\hline ERH8 & 22 & 0,879602625 & Clinton - Golfo do Mississipi \\
\hline$F 3$ & 23 & 0,876952484 & Guarapuava - Paranaguá \\
\hline F5 & 24 & 0,866603811 & Chapadão do Sul - Santos \\
\hline ERF12 & 25 & 0,847131707 & Faribault - NPW \\
\hline ERF6 & 26 & 0,822134034 & Webster - NPW \\
\hline ERF1 & 27 & 0,819313579 & Edgard - NPW \\
\hline ERF11 & 28 & 0,815200559 & Conttonwood - NPW \\
\hline ERH11 & 29 & 0,810217876 & Cottonwood - Golfo do Mississipi \\
\hline ERF10 & 30 & 0,790553807 & Lac Qui Parle - NPW \\
\hline ERF7 & 31 & 0,787100883 & Knox - NPW \\
\hline ERH1O & 32 & 0,78107255 & Lac Qui Parle - Golfo do Mississipi \\
\hline$R F 2$ & 33 & 0,722523445 & Ijuí - Rio Grande \\
\hline$E R F 8$ & 34 & 0,703212827 & Clinton - NPW \\
\hline$F 2$ & 35 & 0,694639672 & Londrina - Paranaguá \\
\hline ERF4 & 36 & 0,646545062 & Plymouth - NPW \\
\hline$R 26$ & 37 & 0,59069863 & Sorriso - Santos \\
\hline ERF9 & 38 & 0,503624623 & Montgomery - NPW \\
\hline RFH1 & 39 & 0,503624623 & Ijuí - Rio Grande \\
\hline EHI & 40 & 0,503624623 & New Madrid - Golfo do Mississipi \\
\hline$R 1$ & 41 & 0,503624623 & Ijuí - Rio Grande \\
\hline$R 3$ & 42 & 0,503624623 & Bagé - Rio Grande \\
\hline$R F 9$ & 43 & 0,503624623 & Sorriso - Paranaguá \\
\hline RH6 & 44 & 0,503624623 & Bagé - Rio Grande \\
\hline$R 6$ & 45 & 0,503624623 & Guarapuava - Paranaguá \\
\hline ERF5 & 46 & 0,503624623 & Woodbury - NPW \\
\hline ERF15 & 47 & 0,503624623 & New Madrid - NPW \\
\hline RH4 & 48 & 0,503624618 & Ijuí - Rio Grande \\
\hline RH8 & 49 & 0,495917576 & Santa Maria - Rio Grande \\
\hline RH9 & 50 & 0,481854246 & Bagé - Rio Grande \\
\hline$R F 11$ & 51 & 0,477028802 & Primavera do Leste - Santos \\
\hline RH5 & 52 & 0,444024009 & Santa Maria - Rio Grande \\
\hline$R H 3$ & 53 & 0,441287885 & Bagé - Rio Grande \\
\hline$R 2$ & 54 & 0,430787364 & Santa Maria - Rio Grande \\
\hline RH2 & 55 & 0,40728215 & Santa Maria - Rio Grande \\
\hline
\end{tabular}




\begin{tabular}{|c|c|c|c|}
\hline$R 24$ & 56 & 0,407033969 & Primavera do Leste - Santos \\
\hline$R F 12$ & 57 & 0,375058646 & Sorriso - Santos \\
\hline$R F 1$ & 58 & 0,369552242 & Londrina - Paranaguá \\
\hline$R 23$ & 59 & 0,369289427 & Primavera do Leste - Paranaguá \\
\hline RHI & 60 & 0,360762065 & Ijuí - Rio Grande \\
\hline$R F 8$ & 61 & 0,359887456 & Primavera do Leste - Paranaguá \\
\hline RH7 & 62 & 0,337264156 & Ijuí - Rio Grande \\
\hline$R 4$ & 63 & 0,243291065 & Londrina - Paranaguá \\
\hline$R 25$ & 64 & 0,231230451 & Sorriso - Paranaguá \\
\hline$R H F 2$ & 65 & 0,215937085 & Rio Verde - Santos \\
\hline$R 9$ & 66 & 0,208124673 & Cascável - Santos \\
\hline$R H F 1$ & 67 & 0,206500502 & Jataí - Santos \\
\hline$R 5$ & 68 & 0,18651442 & Londrina - Santos \\
\hline ERF14 & 69 & 0,181763275 & Audrain - NPW \\
\hline$R 7$ & 70 & 0,180112418 & Guarapuava - Santos \\
\hline ERH14 & 71 & 0,170039556 & Audrain - Golfo do Mississipi \\
\hline ERF13 & 72 & 0,158974994 & Nodaway - NPW \\
\hline ERH13 & 73 & 0,127363022 & Nodaway - Golfo do Mississipi \\
\hline$R 8$ & 74 & 0,096804417 & Cascável - Paranaguá \\
\hline R14 & 75 & 0,089549218 & Chapadão do Sul - Paranaguá \\
\hline$R 15$ & 76 & 0,082518398 & Chapadão do Sul - Santos \\
\hline RHR10 & 77 & 0,055658827 & Canaran - Santos \\
\hline$R 17$ & 78 & 0,055459483 & Jataí - Santos \\
\hline RHR9 & 79 & 0,054942009 & Canarana - Santos \\
\hline$R 16$ & 80 & 0,043888416 & Jataí - Paranaguá \\
\hline RHR2 & 81 & 0,041357872 & Jataí - Santos \\
\hline RHRl & 82 & 0,039202268 & Jataí - Santos \\
\hline$R 10$ & 83 & 0,038070484 & Dourados - Paranaguá \\
\hline RF4 & 84 & 0,03791929 & Sidrolândia - Santos \\
\hline$R F 5$ & 85 & 0,036812439 & Jataí - Paranaguá \\
\hline RHF3 & 86 & 0,035921118 & Cristalina - Santos \\
\hline$R 20$ & 87 & 0,035162627 & Cristalina - Santos \\
\hline$R 13$ & 88 & 0,034791541 & Sidrolândia - Santos \\
\hline RF6 & 89 & 0,034791405 & Rio Verde - Paranaguá \\
\hline$R 12$ & 90 & 0,034624231 & Sidrolândia - Paranaguá \\
\hline$R 18$ & 91 & 0,034584272 & Rio Verde - Paranaguá \\
\hline$R 19$ & 92 & 0,03430441 & Rio Verde - Santos \\
\hline$R 11$ & 93 & 0,034202147 & Dourados - Santos \\
\hline$R F 7$ & 94 & 0,032020326 & Canarana - Paranaguá \\
\hline RF10 & 95 & 0,031978606 & Canarana - Santos \\
\hline$R 22$ & 96 & 0,031815202 & Canarana - Santos \\
\hline RHR5 & 97 & 0,031562524 & Cristalina - Santos \\
\hline RHR6 & 98 & 0,031534094 & Cristalina - Santos \\
\hline$R 21$ & 99 & 0,031303637 & Canarana - Paranaguá \\
\hline RHR4 & 100 & 0,031122246 & Rio Verde - Santos \\
\hline RHR3 & 101 & 0,031084882 & Rio Verde - Santos \\
\hline$R F 3$ & 102 & 0,025730271 & Dourados - Santos \\
\hline
\end{tabular}

Tabela 19 Resultados do Cenário B.

\begin{tabular}{|c|c|c|c|}
\hline \multicolumn{4}{|c|}{ CENÁRIO B } \\
\hline & & & Rota \\
\hline Código & Ranking & $\begin{array}{c}\text { Eficiência } \\
\text { (Índice Composto) }\end{array}$ & (Origem - Destino) \\
\hline ERH9 & 1 & 1 & Montgomery - Golfo do Mississipi \\
\hline RHR12 & 2 & 0,997572861 & Primavera do Leste - Santos \\
\hline ERH12 & 3 & 0,997469802 & Faribault - Golfo do Mississipi \\
\hline ERH4 & 4 & 0,997012032 & Plymouth - Golfo do Mississipi \\
\hline ERH6 & 5 & 0,996650215 & Webster - Golfo do Mississipi \\
\hline RHF6 & 6 & 0,996522388 & Primavera do Leste - Santos \\
\hline ERH3 & 7 & 0,995843673 & Mclean - Golfo do Mississipi \\
\hline ERH7 & 8 & 0,994194972 & Knox - Golfo do Mississipi \\
\hline ERH2 & 9 & 0,99361018 & Champaign - Golfo do Mississipi \\
\hline ERH1 & 10 & 0,993505061 & Edgard - Golfo do Mississipi \\
\hline ERH5 & 11 & 0,990036942 & Woodbury - Golfo do Mississipi \\
\hline RHR11 & 12 & 0,986611966 & Primavera do Leste - Santos \\
\hline$F H 1$ & 13 & 0,984454152 & Santa Maria - Rio Grande \\
\hline
\end{tabular}




\begin{tabular}{|c|c|c|c|}
\hline$F 1$ & 14 & 0,975056938 & Santa Maria - Rio Grande \\
\hline RH6 & 15 & 0,968710787 & Bagé - Rio Grande \\
\hline$F 3$ & 16 & 0,966323311 & Guarapuava - Paranaguá \\
\hline$E H 1$ & 17 & 0,965189795 & New Madrid - Golfo do Mississipi \\
\hline$R 3$ & 18 & 0,96263549 & Bagé - Rio Grande \\
\hline F4 & 19 & 0,948623583 & Cascável - Paranaguá \\
\hline RHF4 & 20 & 0,947629674 & Sorriso - Santos \\
\hline RHR8 & 21 & 0,942455072 & Sorriso - Santos \\
\hline RHR7 & 22 & 0,915612397 & Sorriso - Santos \\
\hline ERH8 & 23 & 0,902166877 & Clinton - Golfo do Mississipi \\
\hline R6 & 24 & 0,866657642 & Guarapuava - Paranaguá \\
\hline F5 & 25 & 0,86499369 & Chapadão do Sul - Santos \\
\hline ERF6 & 26 & 0,819903267 & Webster - NPW \\
\hline ERF1 & 27 & 0,817090461 & Edgard - NPW \\
\hline ERH11 & 28 & 0,772961642 & Cottonwood - Golfo do Mississipi \\
\hline$F 2$ & 29 & 0,764478855 & Londrina - Paranaguá \\
\hline ERH1O & 30 & 0,750181485 & Lac Qui Parle - Golfo do Mississipi \\
\hline$R F 2$ & 31 & 0,720809845 & Ijuí - Rio Grande \\
\hline RH5 & 32 & 0,71932338 & Santa Maria - Rio Grande \\
\hline$R 2$ & 33 & 0,691022024 & Santa Maria - Rio Grande \\
\hline ERF12 & 34 & 0,670974911 & Faribault - NPW \\
\hline ERF11 & 35 & 0,659002035 & Conttonwood - NPW \\
\hline ERF10 & 36 & 0,646071802 & Lac Qui Parle - NPW \\
\hline$E R F 2$ & 37 & 0,633652132 & Champaign - NPW \\
\hline ERF3 & 38 & 0,623879527 & Mclean - NPW \\
\hline$R 26$ & 39 & 0,589095833 & Sorriso - Santos \\
\hline RH8 & 40 & 0,562061376 & Santa Maria - Rio Grande \\
\hline RHF5 & 41 & 0,555817722 & Canarana - Santos \\
\hline RH9 & 42 & 0,541873936 & Bagé - Rio Grande \\
\hline RH3 & 43 & 0,54022322 & Bagé - Rio Grande \\
\hline$R 4$ & 44 & 0,53101161 & Londrina - Paranaguá \\
\hline RH2 & 45 & 0,530482017 & Santa Maria - Rio Grande \\
\hline ERF8 & 46 & 0,528157376 & Clinton - NPW \\
\hline$R F 1$ & 47 & 0,520496969 & Londrina - Paranaguá \\
\hline RH4 & 48 & 0,502258092 & Ijuí - Rio Grande \\
\hline RFH1 & 49 & 0,502258092 & Ijuí - Rio Grande \\
\hline ERF5 & 50 & 0,502258092 & Woodbury - NPW \\
\hline$R 1$ & 51 & 0,502258092 & Ijuí - Rio Grande \\
\hline ERH14 & 52 & 0,490268441 & Audrain - Golfo do Mississipi \\
\hline$R F 11$ & 53 & 0,47543252 & Primavera do Leste - Santos \\
\hline ERF7 & 54 & 0,43527324 & Knox - NPW \\
\hline$R 24$ & 55 & 0,405929526 & Primavera do Leste - Santos \\
\hline$R 5$ & 56 & 0,403792928 & Londrina - Santos \\
\hline$R 8$ & 57 & 0,391664523 & Cascável - Paranaguá \\
\hline ERF4 & 58 & 0,379357611 & Plymouth - NPW \\
\hline$R F 12$ & 59 & 0,374040962 & Sorriso - Santos \\
\hline$R 23$ & 60 & 0,3682874 & Primavera do Leste - Paranaguá \\
\hline$R 7$ & 61 & 0,366534931 & Guarapuava - Santos \\
\hline RHI & 62 & 0,359783177 & Ijuí - Rio Grande \\
\hline$R F 8$ & 63 & 0,355219351 & Primavera do Leste - Paranaguá \\
\hline ERH13 & 64 & 0,354664637 & Nodaway - Golfo do Mississipi \\
\hline RH7 & 65 & 0,336349026 & Ijuí - Rio Grande \\
\hline$R 9$ & 66 & 0,255233668 & Cascável - Santos \\
\hline$R 25$ & 67 & 0,230500574 & Sorriso - Paranaguá \\
\hline$R F 9$ & 68 & 0,221772581 & Sorriso - Paranaguá \\
\hline ERF9 & 69 & 0,212795404 & Montgomery - NPW \\
\hline RHF1 & 70 & 0,205940189 & Jataí - Santos \\
\hline$R H F 2$ & 71 & 0,204181183 & Rio Verde - Santos \\
\hline$R 15$ & 72 & 0,141435464 & Chapadão do Sul - Santos \\
\hline RF10 & 73 & 0,137548484 & Canarana - Santos \\
\hline$R 17$ & 74 & 0,116601648 & Jataí - Santos \\
\hline$R 19$ & 75 & 0,096849357 & Rio Verde - Santos \\
\hline$R 10$ & 76 & 0,084180014 & Dourados - Paranaguá \\
\hline R14 & 77 & 0,073875839 & Chapadão do Sul - Paranaguá \\
\hline$R 22$ & 78 & 0,06801409 & Canarana - Santos \\
\hline RHR10 & 79 & 0,065812653 & Canaran - Santos \\
\hline ERF13 & 80 & 0,060079512 & Nodaway - NPW \\
\hline RHR2 & 81 & 0,059064865 & Jataí - Santos \\
\hline
\end{tabular}




\begin{tabular}{cccc}
$E R F 14$ & 82 & 0,058721294 & Audrain - NPW \\
$E R F 15$ & 83 & 0,054841099 & New Madrid - NPW \\
$R H R 9$ & 84 & 0,054295323 & Canarana - Santos \\
$R 16$ & 85 & 0,04376933 & Jataí - Paranaguá \\
$R H R 4$ & 86 & 0,041770497 & Rio Verde - Santos \\
$R H R 1$ & 87 & 0,039095897 & Jataí - Santos \\
$R F 5$ & 88 & 0,036712556 & Jataí - Paranaguá \\
$R 11$ & 89 & 0,034109343 & Dourados - Santos \\
$R H R 6$ & 90 & 0,031672452 & Cristalina - Santos \\
$R 20$ & 91 & 0,030834784 & Cristalina - Santos \\
$R 13$ & 92 & 0,028833996 & Sidrolândia - Santos \\
$R 21$ & 93 & 0,028115777 & Canarana - Paranaguá \\
$R 12$ & 94 & 0,026756568 & Sidrolândia - Paranaguá \\
$R 18$ & 95 & 0,02672615 & Rio Verde - Paranaguá \\
$R F 7$ & 96 & 0,02565265 & Canarana - Paranaguá \\
$R F 6$ & 97 & 0,024056066 & Rio Verde - Paranaguá \\
$R F 3$ & 98 & 0,023290693 & Dourados - Santos \\
$R F 4$ & 99 & 0,023013834 & Sidrolândia - Santos \\
$R H R 3$ & 100 & 0,022647332 & Rio Verde - Santos \\
$R H F 3$ & 101 & 0,021331345 & Cristalina - Santos \\
$R H R 5$ & 102 & 0,018808398 & Cristalina - Santos \\
\hline
\end{tabular}

Tabela 20 Resultados do Cenário C.

\begin{tabular}{|c|c|c|c|}
\hline \multicolumn{4}{|c|}{ CENÁRIO C } \\
\hline Código & Ranking & $\begin{array}{c}\text { Eficiência } \\
\text { (Índice Composto) }\end{array}$ & $\begin{array}{c}\text { Rota } \\
\text { (Origem - Destino) }\end{array}$ \\
\hline ERH9 & 1 & 1 & Montgomery - Golfo do Mississipi \\
\hline RHR12 & 2 & 0,998062727 & Primavera do Leste - Santos \\
\hline ERH12 & 3 & 0,997964919 & Faribault - Golfo do Mississipi \\
\hline RHF6 & 4 & 0,997709274 & Primavera do Leste - Santos \\
\hline ERH4 & 5 & 0,997566455 & Plymouth - Golfo do Mississipi \\
\hline ERH6 & 6 & 0,997269721 & Webster - Golfo do Mississipi \\
\hline ERH3 & 7 & 0,996590454 & Mclean - Golfo do Mississipi \\
\hline ERH7 & 8 & 0,995279681 & Knox - Golfo do Mississipi \\
\hline ERH2 & 9 & 0,994740034 & Champaign - Golfo do Mississipi \\
\hline ERH1 & 10 & 0,994650553 & Edgard - Golfo do Mississipi \\
\hline ERH5 & 11 & 0,991807252 & Woodbury - Golfo do Mississipi \\
\hline ERF6 & 12 & 0,989941683 & Webster - NPW \\
\hline RHRI1 & 13 & 0,988765841 & Primavera do Leste - Santos \\
\hline FH1 & 14 & 0,987261642 & Santa Maria - Rio Grande \\
\hline ERF1 & 15 & 0,97690022 & Edgard - NPW \\
\hline ERF5 & 16 & 0,97407773 & Woodbury - NPW \\
\hline RHF4 & 17 & 0,971534057 & Sorriso - Santos \\
\hline RH6 & 18 & 0,970981526 & Bagé - Rio Grande \\
\hline EHI & 19 & 0,968330473 & New Madrid - Golfo do Mississipi \\
\hline$R 3$ & 20 & 0,964798141 & Bagé - Rio Grande \\
\hline RHR8 & 21 & 0,903743556 & Sorriso - Santos \\
\hline RHR7 & 22 & 0,897110448 & Sorriso - Santos \\
\hline F5 & 23 & 0,885508394 & Chapadão do Sul - Santos \\
\hline ERH11 & 24 & 0,770297377 & Cottonwood - Golfo do Mississipi \\
\hline$E R F 2$ & 25 & 0,765585507 & Champaign - NPW \\
\hline ERH8 & 26 & 0,758891951 & Clinton - Golfo do Mississipi \\
\hline ERF3 & 27 & 0,750825993 & Mclean - NPW \\
\hline ERF4 & 28 & 0,742872954 & Plymouth - NPW \\
\hline ERH1O & 29 & 0,742854806 & Lac Qui Parle - Golfo do Mississipi \\
\hline ERF9 & 30 & 0,727415484 & Montgomery - NPW \\
\hline ERF12 & 31 & 0,69354646 & Faribault - NPW \\
\hline ERF11 & 32 & 0,678891359 & Conttonwood - NPW \\
\hline ERF10 & 33 & 0,664136849 & Lac Qui Parle - NPW \\
\hline ERF7 & 34 & 0,655781594 & Knox - NPW \\
\hline$F 1$ & 35 & 0,633356098 & Santa Maria - Rio Grande \\
\hline ERF8 & 36 & 0,623048064 & Clinton - NPW \\
\hline RHF5 & 37 & 0,558534921 & Canarana - Santos \\
\hline$F 3$ & 38 & 0,541197237 & Guarapuava - Paranaguá \\
\hline RH9 & 39 & 0,524601122 & Bagé - Rio Grande \\
\hline
\end{tabular}




\begin{tabular}{|c|c|c|c|}
\hline$F 2$ & 40 & 0,524376884 & Londrina - Paranaguá \\
\hline F4 & 41 & 0,517658567 & Cascável - Paranaguá \\
\hline RH8 & 42 & 0,508230032 & Santa Maria - Rio Grande \\
\hline RH3 & 43 & 0,506351864 & Bagé - Rio Grande \\
\hline RH5 & 44 & 0,485323652 & Santa Maria - Rio Grande \\
\hline$R 2$ & 45 & 0,475854624 & Santa Maria - Rio Grande \\
\hline ERH14 & 46 & 0,467348863 & Audrain - Golfo do Mississipi \\
\hline RH2 & 47 & 0,462625091 & Santa Maria - Rio Grande \\
\hline RF11 & 48 & 0,454068612 & Primavera do Leste - Santos \\
\hline$R F 1$ & 49 & 0,427463485 & Londrina - Paranaguá \\
\hline$R F 12$ & 50 & 0,402797036 & Sorriso - Santos \\
\hline$R 6$ & 51 & 0,378042283 & Guarapuava - Paranaguá \\
\hline$R 24$ & 52 & 0,35636779 & Primavera do Leste - Santos \\
\hline$R F 8$ & 53 & 0,348518082 & Primavera do Leste - Paranaguá \\
\hline$R F 2$ & 54 & 0,346849199 & Ijuí - Rio Grande \\
\hline$R 23$ & 55 & 0,343694798 & Primavera do Leste - Paranaguá \\
\hline$R 4$ & 56 & 0,331795199 & Londrina - Paranaguá \\
\hline$R 8$ & 57 & 0,305530853 & Cascável - Paranaguá \\
\hline$R 26$ & 58 & 0,301317543 & Sorriso - Santos \\
\hline$R 5$ & 59 & 0,289619444 & Londrina - Santos \\
\hline ERH13 & 60 & 0,283561672 & Nodaway - Golfo do Mississipi \\
\hline$R 7$ & 61 & 0,273422242 & Guarapuava - Santos \\
\hline$R H F 2$ & 62 & 0,252620952 & Rio Verde - Santos \\
\hline$R H F 1$ & 63 & 0,243434019 & Jataí - Santos \\
\hline$R 9$ & 64 & 0,226789252 & Cascável - Santos \\
\hline RF9 & 65 & 0,223317978 & Sorriso - Paranaguá \\
\hline$R 25$ & 66 & 0,156054185 & Sorriso - Paranaguá \\
\hline$R F 10$ & 67 & 0,141348622 & Canarana - Santos \\
\hline$R 15$ & 68 & 0,122960739 & Chapadão do Sul - Santos \\
\hline RHF3 & 69 & 0,122847642 & Cristalina - Santos \\
\hline RFHI & 70 & 0,10151996 & Ijuí - Rio Grande \\
\hline$R 19$ & 71 & 0,082763677 & Rio Verde - Santos \\
\hline$R 17$ & 72 & 0,077112558 & Jataí - Santos \\
\hline RH7 & 73 & 0,072614348 & Ijuí - Rio Grande \\
\hline RH4 & 74 & 0,071016265 & Ijuí - Rio Grande \\
\hline RHI & 75 & 0,069878133 & Ijuí - Rio Grande \\
\hline$R 1$ & 76 & 0,069258324 & Ijuí - Rio Grande \\
\hline R14 & 77 & 0,067932403 & Chapadão do Sul - Paranaguá \\
\hline RF5 & 78 & 0,065265307 & Jataí - Paranaguá \\
\hline ERF13 & 79 & 0,062891607 & Nodaway - NPW \\
\hline ERF14 & 80 & 0,062766317 & Audrain - NPW \\
\hline RF6 & 81 & 0,062511816 & Rio Verde - Paranaguá \\
\hline ERF 15 & 82 & 0,058851644 & New Madrid - NPW \\
\hline RHR10 & 83 & 0,058471532 & Canaran - Santos \\
\hline RHR9 & 84 & 0,049006825 & Canarana - Santos \\
\hline$R 10$ & 85 & 0,043993694 & Dourados - Paranaguá \\
\hline$R 22$ & 86 & 0,042746506 & Canarana - Santos \\
\hline$R H R 2$ & 87 & 0,036789582 & Jataí - Santos \\
\hline RHR4 & 88 & 0,03329984 & Rio Verde - Santos \\
\hline RHR6 & 89 & 0,025283426 & Cristalina - Santos \\
\hline$R 20$ & 90 & 0,023022831 & Cristalina - Santos \\
\hline$R 13$ & 91 & 0,022811091 & Sidrolândia - Santos \\
\hline$R 12$ & 92 & 0,021254233 & Sidrolândia - Paranaguá \\
\hline$R 18$ & 93 & 0,021179551 & Rio Verde - Paranaguá \\
\hline$R 16$ & 94 & 0,020890127 & Jataí - Paranaguá \\
\hline RHRI & 95 & 0,020330357 & Jataí - Santos \\
\hline RF4 & 96 & 0,019980528 & Sidrolândia - Santos \\
\hline R11 & 97 & 0,017769188 & Dourados - Santos \\
\hline$R F 3$ & 98 & 0,017007922 & Dourados - Santos \\
\hline RHR3 & 99 & 0,016171738 & Rio Verde - Santos \\
\hline RHR5 & 100 & 0,014341136 & Cristalina - Santos \\
\hline$R 21$ & 101 & 0,013755152 & Canarana - Paranaguá \\
\hline$R F 7$ & 102 & 0,012733262 & Canarana - Paranaguá \\
\hline
\end{tabular}

